UNIVERSIDADE DE SÃO PAULO

INSTITUTO DE GEOCIÊNCIAS

\title{
PETROGRAFIA E QUIMICA DOS IGNIMBRITOS DO CERRO PULULUS E SUA CORRELAÇÃO COM DEPÓSITOS DA CALDEIRA VILAMA, PUNA, ANDES \\ CENTRAIS, NW DA ARGENTINA
}

\author{
Liza Angélica Polo \\ Orientadora: Profa. Dra. Mabel Norma Costa Ulbrich \\ DISSERTAÇÃO DE MESTRADO
}

Programa de Pós-Graduação em Mineralogia e Petrologia

SÃO PAULO

2008 
À minha pequena Catarina. 


\section{SUMÁRIO}



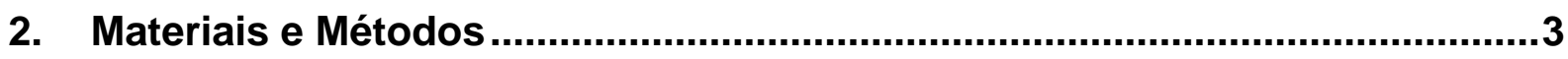

2.1 Levantamento bibliográfico e fotointerpretação.............................................. 3



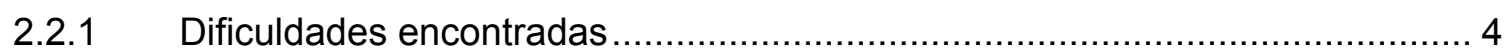

$2.3 \quad$ Análises de laboratório ................................................................................. 4

2.3.1 Análise petrográfica e contagem modal ................................................... 4

2.3.2 Análises dos minerais por microssonda eletrônica ……………………….... 5



3. Terminologia, Classificações e Conceitos Utilizados no Relatório ................8



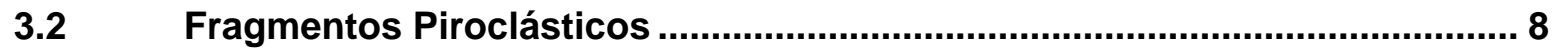

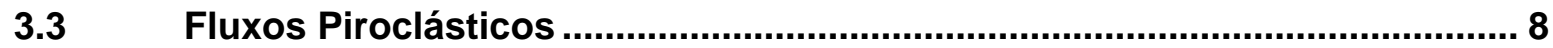

3.3.1 Fluxos Piroclásticos de púmice e Depósitos ............................................. 9

3.3.3 Classificação dos depósitos ignimbríticos................................................ 10

3.4 Soldamento e Processos pós- deposicionais.............................................. 11

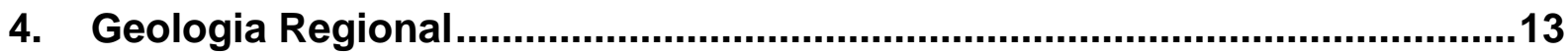

4.1 Zona Vulcânica Central dos Andes (ZVC) ……......................................... 13

4.2 Altiplano-Puna......................................................................................... 13

4.3 Evolução tectônica e sedimentação da Puna Setentrional........................... 15

4.4 Complexo Vulcânico Altiplano Puna (CVAP) ……........................................ 16

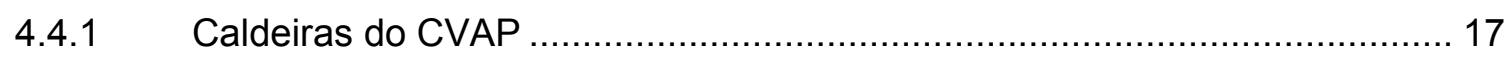

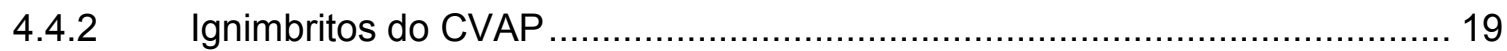

4.5 Complexo de Caldeiras Vilama-Coruto ................................................. 20












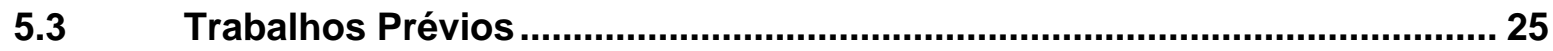

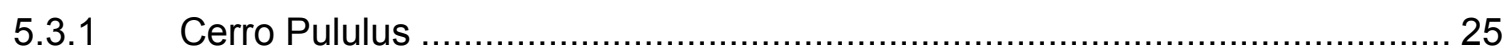

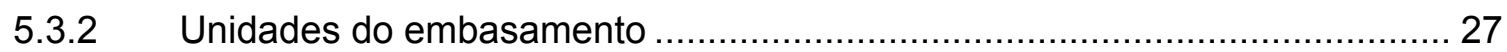

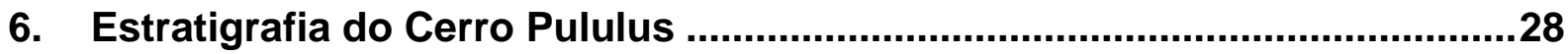

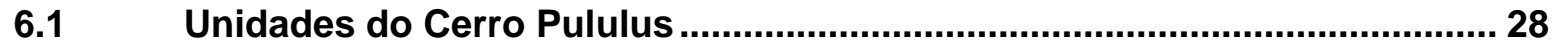



6.2.2 Unidade de Fluxo Rosado Inferior (UFRI) ............................................... 32

6.2.3 Unidade de Fluxo Rosado Superior (UFRS) ........................................... 34

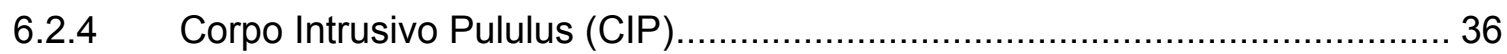

7. Petrografia e Química dos principais minerais .........................................37





7.1.2 Fragmentos vítreos (glass-shards) …........................................................ 39

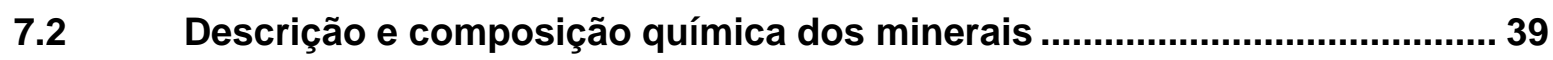

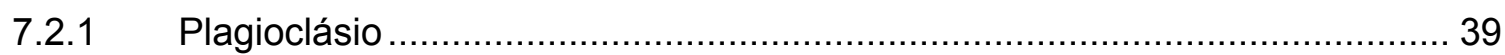

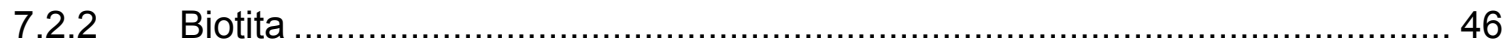

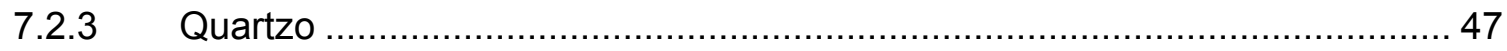

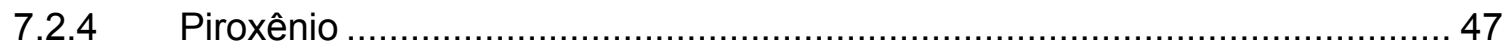

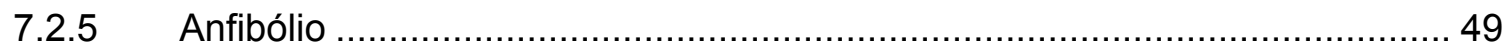

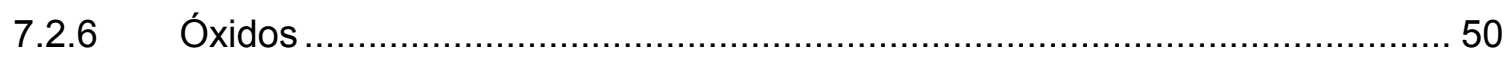

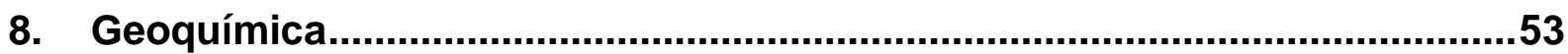

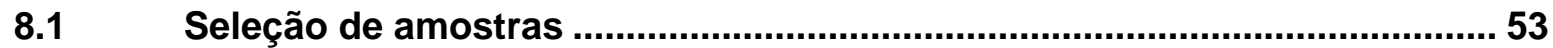

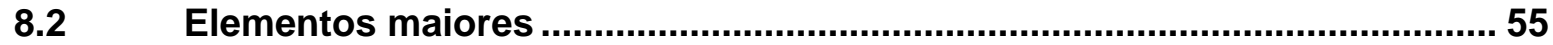



8.2.2 Unidade de Fluxo Rosa Inferior (UFRI) .................................................. 57

8.2.3 Unidade de Fluxo Rosa Superior (UFRS) ….......................................... 60

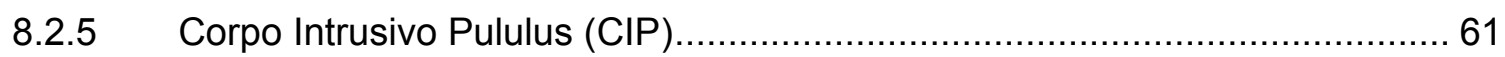

$8.3 \quad$ Elementos Traços e Terras Raras .................................................................. 61

9. Discussão e Interpretações dos Resultados ............................................65

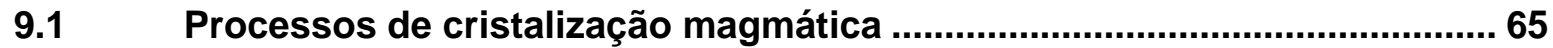


9.1.1 Evidências de instabilidade na câmara registradas pelo plagioclásio ...........66 66

9.1.2 Condições pré-eruptivas do magma registradas pela hornblenda................. 69

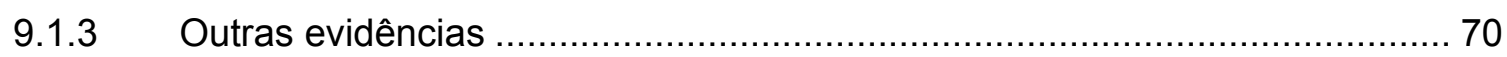

9.2 Pequenas heterogeneidades composicionais dos depósitos..................... 71

10. Relação dos depósitos de Pululus com ignimbritos da Caldeira Vilama....72

$10.1 \quad$ Estratigrafia do Ign. Vilama.............................................................................. 73

10.2 Petrografia e Química Mineral do Ign. Vilama e do $C^{\circ}$ Pululus..................... 73

10.2.1 Classificação dos principais minerais constituintes ..................................... 74

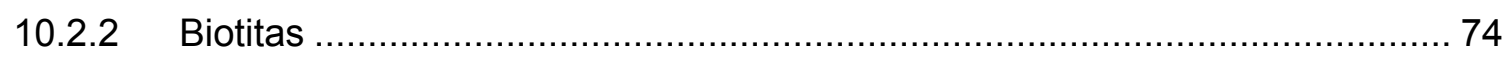

10.3 Geoquímica do Ign. Vilama e do $C^{\circ}$ Pululus.................................................... 76



10.4.1 Modelo eruptivo para os depósitos do Cerro Pululus .................................. 77

10.4.2 Modelo eruptivo para o Ign. Vilama (SOLER, 2005; SOLER et al., 2007)..... 78

10.4.3 Discussão e comparação entre modelos .................................................. 79

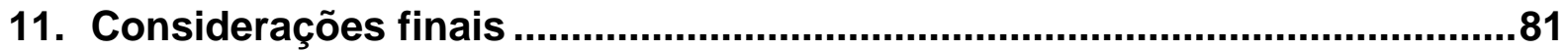

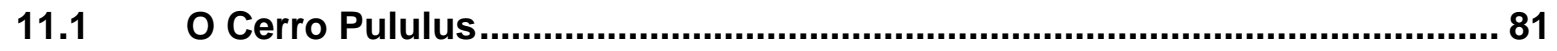

11.2 Correlação com os depósitos da Caldeira Vilama........................................... 86

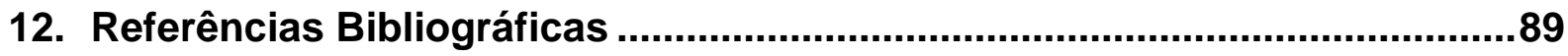




\section{ÍNDICE DE FIGURAS}

Figura 01. Esquemas a) coluna eruptiva com geração de fluxo piroclástico (adaptado de FISHER, 1979); b) depósito piroclástico (adaptado de SPARKS et al., 1973)

Figura 02. Figura esquemática que contrasta as diferenças entre os depósito do tipo HARI e LARI (Adaptado de WALKER, 1983).

Figura 03. Figura esquemática das zonas de soldamento e processos associados em unidade simples de resfriamento (SMITH, 1960).

Figura 04. Mapa esquemático da Placa Sul-americana indicando as 4 zonas vulcânicas ativas dos Andes Centrais

Figura 05. Mapa esquemático de localização nos Andes Centrais do Platô AltiplanoPuna (adaptado de ALLMENDINGER et al., 1997).

Figura 06. Mapa esquemático do Complexo Vulcânico Altiplano-Puna (CVAP) na Zona Vulcânica Central (ZVC) dos Andes. O esquema também apresenta a extensão aproximada dos afloramentos ignimbriticos depositados durante 0 Neógeno Superior e as principais caldeiras vulcânicas do Complexo (adaptado de SILVA e FRANCIS, 1991).

Figura 07. Extensão aproximada do "Altiplano-Puna Magma Body" (APMB), segundo SILVA et al. 2007.

Figura 08. a) Mapa geológico do Complexo de Caldeiras Vilama-Coruto, segundo Coira et al, 1996 (adaptado por SOLER et al, 2007); b) Nova definição de tamanho e localização da caldeira Vilama, e extensão do Ignimbrito Vilama, segundo Soler et al, 2007.

Figura 09. Mapa da província de Jujuy, Argentina, apresentando os caminhos de acesso para chegar ao $\mathrm{C}^{\circ}$ Pululus.

Figura 10. Imagem de satélite e fotomontagem do $C^{\circ}$ Pululus. A fotografia foi tirada na ponta NW de Pululus.

Figura 11. Mapa geológico do Cerro Pululus (adaptado de Polo, 2004) com unidades do embasamento (segundo, Coira et al., 1996) .

Figura 12. Perfil esquemático dos afloramentos pertencentes à UFC, localizados a oeste do $\mathrm{C}^{\circ}$ Pululus

Figura 13. Figura esquemática do perfil 03, com afloramentos da UFRI e UFRS 33 
Figura 14. Diagramas ternários An-Ab-Or para classificação dos feldspatos.

Figura 15. Diagramas de variação anortita x ortoclásio para plagioclásios pertencentes às diferentes unidades do $C^{\circ}$ Pululus.

Figura 15 (continuação) 45

Figura 15 (continuação) 46

Figura 16. Diagramas Wo-En-Fs para classificação dos piroxênios de Morimoto et al., (1989).

Figura 17.Diagramas de classificação para hornblendas. a) classificação geral de hornblenda nos quatro grupos principais, b) classificação para hornblendas cálcicas $\left[(\mathrm{Na}+\mathrm{K})_{A}<0,5\right]$, segundo Leake et al. (1997). 50

Figura 18. Diagramas de classificação geoquímica para os depósitos do Co Pululus. a) Diagrama TAS (LE BAS et al., 1986); b) Diagrama de saturação de alumínio $\left(\mathrm{SiO}_{2}\right.$ versus proporções molares de $\left.\mathrm{Al} /(\mathrm{K}+\mathrm{Na}+\mathrm{Ca})\right)$; c) Diagrama de conteúdo em potássio (GILL, 1981).

Figura 19.Diagramas tipo Harker de elementos maiores $\times \mathrm{SiO}_{2}$ para amostras representativas de lápilli-púmice das diferentes unidades do cerro ........58/59

Figura 20.Diagramas de elementos traços $x \mathrm{SiO}_{2}$ e mg\# para amostras representativas de lápilli-púmice das diferentes unidades do cerro

Figura 21. Diagramas de distribuição de Elementos Terras Raras. a) apenas para unidades de fluxo piroclástico do $C^{\circ}$ Pululus; b) Comparação do depósito do $\mathrm{C}^{\circ}$ Pululus (unificado) com amostras do CIP, Ign. Vilama e FLP.

Figura 22.

Figura 23. Correlação dos depósitos do Co Pululus com Ign. Vilama (SOLER, 2005) a partir da química mineral (Fe-Ti-Mn-Mg) de fenocristais de biotita. .75

Figura 24. Diagramas do tipo Harker para análises de lapilli-púmice (exceto Ign. Vilama, c/ análise de rocha total) de ignimbritos do APVC e diagrama de classificação TAS (LE BAS et al., 1986). 


\section{ÍNDICE DE FOTOS}

Foto 1. Fotomontagem mostrando o Cerro Pululus (Figura 10). 10

Foto 2. Foto do depósito UFC, fácies $1 \mathrm{~A}$, mostrando riqueza em fragmentos líticos....31

Foto 3. Foto do depósito UFC, fácies $1 \mathrm{~A}$, fragmento lítico de $34 \mathrm{~cm}$.

Foto 4. Foto do depósito UFC, contato da fácies $1 \mathrm{~b}$ com fávies 2.

Foto 5. Contato da UFC com UFRS.

Foto 6. Fragmento lítico em meio a grande quantidade de lapilli-púmices. 33

Foto 7. Lapilli púmices achatados com razões de 6:1. 33

Foto 8. Blocos-púmices no topo da UFRI. 33

Foto 9. Lapilli-púmices que se despreendem da rocha,unidade UFRS. 33

Foto 10.Afloramento da UFRI, com grande quantidade e diversidade de púmices. 35

Foto 11. Amostra de mão contendo púmice branco, rosa, cinza, fiamme vermelho e fragmento lítico.

Foto 12. Perfil completo que apresenta as três unidades.

Foto 13. Detalhe do afloramento mostrando contato entre UFC e UFRI.

Foto 14. Fotomicrografia de matriz com lapilli púmice desvitrificado e rico em cristais. Amostra PUL-20A

Foto 15. Fotomicrografia de matriz com textura axiolitica de desvitrificação ao redor de estruturas de lithophysaes. Amostra PUL-37F

Foto 16. Fotomicrografia de matriz de lapilli-púmice cinza com fino bandamento de minerais máficos intercalada aos minerais félsicos. Amostra PUL-44B......40

Foto 17. Fotomicrografia de nódulos de minerais máficos presentes nos púmices. Amostra PUL-44

Foto 18. Fotomicrografia de matriz com textura eutaxitica entre doislapilli púmice 41

Foto 19. Fotomicrografia de matriz com púmice em sigmóide

Foto 20. Fotomicrografia de matriz com cristaloclastos rotacionados indicando que a rocha foi afetada por reomorfismo. 
Foto 21. Fotomicrografia de púmice da UFRS com textura perlitica associada a desvitrificação

Foto 22. Fotomicrografia de fenocristal de plagioclásio com zoneamento irregular e feições de reabsorção. Amostra PUL-18

Foto 23. Fotomicrografia de fenocristal de plagioclásio com textura em peneira. Amostra PUI-38A

Foto 24. Fotomicrografia de microfenocristal de plagioclásio com núcleo reabsorvido e concentração de inclusões fluidas acompanhando zona interna do cristal. Amostra PUL-08

Foto 25. Fotomicrografia de fenocristal de biotita manteado por plagioclásio. Amostra PUL-20A

Foto 26. Fotomicrografia de matriz com grandes cristaloclastos de quartzo embainhado e púmices com borda difusas e em chama. Amostra PUL-32. 52

Foto 27. Fotomicrografia de fenocristal de quartzo poiquilitico englobando microfenocristais de plagioclásio. Amostra PUL-28A

Foto 28. Fotomicrografia mostrando intercrescimento de ortopiroxênio e plagioclásio.Polarizadores paralelos. Amostra PUL-44D

Foto 29. Fotomicrografia mostrando intercrescimento de ortopiroxênio e plagioclásio.Polarizadores cruzados. Amostra PUL-44D .52 
ÍNDICE DE ANEXOS

Anexo I. Glossário dos termos e expressões utilizados no trabalho

Anexo II. Mapas e Perfis

Figura 1. Mapa de Pontos

Figura 2. Perfis estratigráficos

Figura 3. Apresentação dos perfis selecionados de Soler (2005) para correlação com perfis do Cerro Pululus

Anexo III. Tabela de localização e descrição de afloramentos

Anexo IV. Descrições Petrográficas

Anexo V. Análises de Química Mineral

Tabela 1. Análise de plagioclásio

Tabela 2. Análise de biotita

Tabela 3. Análises de piroxênio

Tabela 4. Análise de anfibólio

Anexo V. Análises de Química de Rocha 


\section{RESUMO}

Entre 12 e 4Ma, intensas manifestações vulcânicas explosivas ocorrem associadas a formação de grandes caldeiras no platô dos Andes Centrais, lançando mais de $10.000 \mathrm{~km}^{3}$ de material piroclástico e constituindo o Complexo Vulcânico Altiplano Puna (CVAP). O Cerro Pululus, com aproximadamente $178 \mathrm{~km}^{2}$ e $550 \mathrm{~m}$ de altura, é uma colina em forma de escudo constituída por três unidades de fluxo ignimbrítico lançadas por um mesmo centro emissor durante os eventos do CVAP. No cume do cerro aflora um corpo intrusivo sub-vulcânico que elevou e deformou os depósitos piroclásticos na forma de um anticlinal. Pululus está localizado na borda sul da Caldeira Vilama, uma das maiores estruturas de colapso do CVAP, que teria sido responsável pela deposição de mais de $1.200 \mathrm{~km}^{3}$ de material piroclástico. O local de emissão dos ignimbritos de Pululus ainda é desconhecido e sua relação com os depósitos da Caldeira Vilama é considerada incerta.

A alta concentração de cristais nos púmices evidencia que os depósitos do Cerro Pululus foram originados por um magma porfirítico, apresentando plagioclásio, biotita, quartzo, ferrossilita, enstatita, augita e hornblenda, como minerais principais. As unidades são de composição dacítica e pertencem à série cálcio-alcalina de alto-K, com características meta a peraluminosas e razões $A / C N K$ variando entre 0,9 e 1,04.

As feições texturais dos minerais (e.g. texturas de dissolução no plagioclásio) e os dados químicos obtidos (e.g. presença de dois tipos de púmices) evidenciam recorrentes injeções máficas na câmara magmática. A alta taxa de cristalinidade da fusão (50 a 68\%) tornou desfavorável o processo de fracionamento e reduziu a ação de correntes de convecção na câmara, evitando a homogeneização do magma.

A presença de bordas de reação nos anfibólios, somada a outras evidências observadas no afloramento, indicam que durante o início do evento eruptivo o magma ascendeu a uma velocidade consideravelmente baixa, permitindo a liberação de uma grande quantidade de voláteis e resultando numa erupção de caráter mais explosivo. Com a abertura do sistema e o abatimento da pressão dentro da câmara, ocorre a aceleração na cristalização do fundido, resultando no progressivo aumento de saturação de água em algumas porções da câmara e a conseqüente estabilização e cristalização de anfibólio antes da última erupção.

A comparação entre os ignimbritos da Caldeira Vilama e Cerro Pululus é feita, neste trabalho, utilizando-se características deposicionais, petrográficas e químicas. Ambos são compostos por três unidades de fluxo que apresentam similaridades quanto à cor, grau de soldamento, relações estratigráficas, quantidade e tipos de púmices, quantidade e tipos de fragmentos líticos, assembléia mineralógica e composição química. Todos esses elementos, além da inexistência de qualquer conduto vulcânico no cerro, permitem estimar que os depósitos de Pululus representem uma extensão do Ignimbrito Vilama. 


\section{ABSTRACT}

About 12 and 4Ma, ago intense' explosive volcanic manifestations occurred associated to the formation of the large calderas in the Andean Central Volcanic Zone plateau, launching more than $10.000 \mathrm{~km} 3$ of ignimbrites and constituting the AltiplanoPuna Volcanic Complex (APVC). The Cerro Pululus, of about $178 \mathrm{~km} 2$ and $550 \mathrm{~m}$ high, is a shield-like hill constituted by three units of ignimbritic flows originated from same emission center during APVC's events. A sub-volcanic intrusive body, that elevated and deformed the pyroclastic deposits in the form of an anticline, crops out at the hill top. Pululus is located in the south ring of the Vilama caldera, one of the largest of the APVC's collapse structures, which would have been responsible for the deposition of more than $1.200 \mathrm{~km} 3$ of pyroclastic material. The emission center of Pululus ignimbrites is still unknown and its relationship with the deposits of the Vilama caldera is considered uncertain.

The high crystal concentration in the pumices evidences that the deposits of Cerro Pululus were originated from a porphyritic magma, with plagioclase, biotite, quartz, ferrosilite, enstatite, augite and hornblend as main minerals. The units are of dacitic composition and belong to the high-K calc-alkaline series, with metaperaluminous characteristics and $\mathrm{A} / \mathrm{CNK}$ reasons between 0.9 and 1.04 .

The textural features of the minerals (e.g. dissolution textures in plagioclase) and the obtained chemical data (e.g. presence of two types of pumices) evidence recurring mafic injections in the magmatic chamber. The high cristallinity rate by the melt (50 to 68\%) turned unfavorable the fractionation process and reduced the convection currents action in the chamber, hindering the homogenization of the magma.

The presence of reaction borders in amphibole, besides some evidences observed in the outcrops, indicate that during the beginning of the eruptive event the magma ascended of a considerably low speed, which allowed the liberation of a great quantity of volatiles and resulted in an eruption of more explosive character. With the opening of the system and the pressure surcease inside the chamber, an acceleration in the crystallization of the melt occurred, resulting in progressive water saturation increase in some portions of the chamber and consequent amphibole stabilization and crystallization before the last eruption.

A comparison between ignimbrites of the Vilama caldera and Cerro Pululus is made, in this work, using depositional, petrographics and chemical characteristic. They are both composed by three flow units that present similarities regarding color, welding, stratigraphic relationships, quantity and types of pumices, quantity and types of lithic fragments, mineralogical assembly and chemical composition. All of these elements, besides the inexistence of any volcanic conduit on the hill, allow to correlate the Pululus' ignimbrites directly with those of Vilama. 


\section{AGRADECIMENTOS}

Após um ano realizando esta dissertação fui surpreendida pela presença de uma menina dentro da minha barriga e é por isso que se não fosse o apoio oferecido por diversas pessoas creio que não teria conseguido levar este trabalho até o final. Agradeço em especial a:

do a minha orientadora Profa. Dra. Mabel N. C. Ulbrich e ao Prof. Dr. Horstpeter H. G. J. Ulbrich que tornaram possível a realização deste projeto. Agradeço a professora Mabel pela atenção, apoio, compreensão e todo o tempo tomado durante a evolução deste trabalho;

2o a Dra. Beatriz Coira do Instituto de Geologia y Mineria da Universidad Nacional de Jujuy, Argentina (IdGyM-UNJu) que também tornou possível a realização deste projeto, e me abriu as portas do instituto. Agradeço pelos ensinamentos e orientação;

¿ ao Dr. Miguel Soler (IdGyM-UNJu), pela companhia ao campo, enriquecedoras discussões e pelo fornecimento de suas amostras;

¿ ao Dr. Pablo Caffe (IdGyM-UNJu) por todo auxílio, ensinamentos, informações e valorosas discussões;

¿o ao geológo Diego Fracchia (IdGyM-UNJu) pelas trocas de informações, discussões e envio de suas amostras;

¿ ao prof. Dr. Gergely Szabó pela correção de meu abstract;

¿ ao funcionário Marcos de S. Mansueto do laboratório de Microssonda Eletrônica (DMG) por todo o acompanhamento antes, durante e após as seções de microssonda. Agradeço por toda paciência e pelos incontáveis "galhos quebrados";

¿ aos funcionários Sandra, Margareth, Ricardo do Laboratório de Química e ICP-AES e Paulo do Laboratório de Fluorescência de Raio-X (DMG-IGc-USP), pelas excelentes análises obtidas e toda a atenção dispensada;

¿ aos funcionários Ana Paula Cabonal e Magali P. F. Rizzo (Secretaria pósgraduação), Sônia G.C.Vieira e Valéria Cristina de S. R. Santos (secretaria DMG) e Tadeu (secretário pós-graduação) por toda a atenção e auxílios;

¿ aos funcionários Angélica (Lab. Óptica) e José Paulo (LTA) pelo acompanhamento durante minhas longas tardes de trabalho;

¿ aos funcionários da gráfica do IGc, pelo trabalho de encardenamento destes volumes;

¿ ao amigo João Rocha Campos pela cuidadosa leitura e correção final desta dissertação. Muitíssimo obrigado!

do a amiga e colega Dra. Lucilene Martins pelas incontáveis e preciosas ajudas, discussões, ensinamentos e sobretudo paciência e carinho durante estes três anos de trabalho;

io a amiga e colega Adriana Alves (Bibi) meu mais sincero e eterno agradecimento. Sem sua ajuda, paciência e amizade este trabalho não teria ido para frente. Obrigado pelos ensinamentos e discussões; 
¿o aos amigos e colegas Bruno Turra (Melado) e Vinicius (Mikuim) pelas discussões, leituras, correções, sugestões, paciência, favores e serviços de baby-siter, meu mais sincero e gigantesco obrigado;

¿o aos amigos Charahzéd L. Morengui, Tatiana Tavares, Renato Henrique Pinto, Bruna Borges, Vídia, Francisco Stuchi e Luana, que em algum momento, de alguma forma e com muito carinho colaboraram diretamente na realização deste trabalho, seja com discussões, favores, idéias, correções vivência ou trabalhos de baby-siter;

¿ ao geológo Javier Palácios que me hospedou em sua casa durante minha última visita a Jujuy e todos os funcionários IdGyM que sempre me dispensaram muita atenção e carinho;

¿ aos Profs. Drs. Silvio R.F. Vlach, Fábio Ramos, Excelso Ruperti, Daniel Atencio e Valdecir Janasi por estarem sempre dispostos em ajudar, conversar e ensinar;

¿ aos amigos e colegas de pós-graduação Juli, Frederico, Gastón, Rogério, Viviani, Taís, Lucas Warren, Bruna, Priscila (Xiwawa), Samar, Bruno (Chuck-nóia) e todos os outros que me acompanharam nesta jornada;

¿ a minha amiga Clarissa que me guiou durante a longa espera da pequena Catarina. A calma e segurança que você me passou certamente tiveram influencia direta neste trabalho;

¿ aos meus pais, Angélica e José, por toda a atenção e ajuda oferecida e especialmente pelas diversas tardes em que cuidaram da pequena Catatu para que eu pudesse prosseguir com o desenvolvimento deste mestrado.

¿ e finalmente ao meu companheiro Antônio, que durante toda a realização desta dissertação não arredou o pé e vivenciou ao meu lado não apenas momentos de dificuldades e cansaço, mas também de intensas emoções e grandes alegrias. Muitíssimo obrigado por toda a ajuda, apoio, ensinamentos, carinho, compreensão e imensa paciência. 


\section{Introdução}

A Zona Vulcânica Central (ZVC) da cadeia Andina não apenas é uma das maiores províncias vulcânicas ativas do mundo, como também uma das que mais carece de estudos geológicos, pois grande parte de sua área está situada em uma região inóspita, despovoada e de difícil acesso, devido a suas grandes altitudes e seu clima extremamente árido.

Essa região de grandes altitudes constitui o denominado platô Altiplano-Puna, altiplano que foi palco de violentas erupções vulcânicas explosivas durante o Mioceno Superior, resultantes do colapso de grandes estruturas caldéricas e responsáveis pela deposição de uma das maiores províncias ignimbríticas do mundo (Complexo Vulcânico Altiplano Puna - CVAP; SILVA, 1989a,b).

O Cerro Pululus, tema deste trabalho, está formado por uma seqüência de depósitos de fluxos piroclásticos que ocupam uma área de aproximadamente $178 \mathrm{~km}^{2}$ e $550 \mathrm{~m}$ de altura. Localiza-se na porção central de uma grande depressão rodeada de lagunas salgadas e centros vulcânicos efusivos e na borda sul de uma grande caldeira do CVAP, conhecida como Caldeira Vilama. É provável que a origem dos depósitos de Pululus esteja relacionada ao episódio de colapso e formação desta caldeira, porém, até o momento, nenhum estudo em detalhe foi realizado para confirmar esta hipótese.

As primeiras citações de Pululus na bibliografia correspondem a trabalhos geológicos de reconhecimento regional realizados nas décadas de 1930 e 1940 que tinham por objetivo a prospecção de jazidas de estanho. A partir do trabalho de Coira et al. (1996), o Cerro Pululus passou a ser considerado como uma unidade piroclástica pertencente ao Complexo de Caldeiras Vilama-Coruto (CCVC), sendo posteriormente excluído por Soler (2005), que não faz qualquer menção sobre os depósitos do cerro.

O primeiro estudo mais específico e detalhado sobre Pululus foi apresentado em Polo (2004), em que se definiu com maior precisão a estratigrafia e mineralogia dos ignimbritos que o conformam, oferecendo-se, assim, um modelo eruptivo e deposicional para o mesmo. Entretanto, a boca de emissão desses fluxos piroclásticos não foi encontrada, da mesma forma que continuou incerta a relação estratigráfica com os outros depósitos do APVC e particularmente com os ignimbritos da Caldeira Vilama.

O presente trabalho teve por objetivo principal caracterizar quimicamente as rochas do Cerro Pululus, identificando, a partir da petrografia, química mineral e 
química de rocha, os processos que atuaram na câmara magmática durante a cristalização da fusão antes que ocorra a erupção. Este estudo também oferece um aprimoramento da estratigrafia e do modelo eruptivo apresentados em Polo (2004), além da possibilidade de realizar uma correlação entre os ignimbritos de Pululus e os pertencentes à Caldeira Vilama com base não apenas nas características de campo e estratigrafia, mas nos estudos petrológicos, geoquímicos, evolução magmática e modelos eruptivos. 


\section{Materiais e Métodos}

A primeira etapa do trabalho foi concretizada no Instituto de Geologia y Mineria da Universidad Nacional de Jujuy (UNJu - Argentina), sob a orientação da Profa. Dra. Beatriz L. Coira. Nessa ocasião realizou-se um levantamento bibliográfico sobre a geologia regional, local e específica, a fotointerpretação geológica da área a ser estudada, seguida do trabalho de campo para coleta de dados, e a obtenção de amostras destinadas a estudos em gabinete e laboratório.

A segunda etapa foi desenvolvida no Instituto de Geociências da Universidade de São Paulo (IGc-USP), sob orientação da Profa. Dra. Mabel N. C. Ulbrich. Esta consistiu na seleção e preparação de amostras para posteriores análises em laboratório (petrografia, química mineral, química de rocha e geocronologia), da confecção dos mapas, do glossário e da dissertação.

Abaixo, seguem os itens que listam detalhadamente todas as tarefas realizadas:

\subsection{Levantamento bibliográfico e fotointerpretação}

a) Revisão bibliográfica específica sobre vulcanismo explosivo, mecanismos de transporte de piroclastos e depósitos;

b) Revisão bibliográfica sobre o Complexo Vulcânico Altiplano Puna (CVAP), particularmente sobre os ignimbritos gerados dentro dessa região ente o Mioceno Superior e o Plioceno, e o tipo de vulcanismo associado;

c) Revisão bibliográfica sobre os estudos geológicos do $C^{\circ}$ Pululus;

d) Foto-interpretação geológica da área, com fotografias áreas de escala 1:50.000 e imagens de satélites na escala 1:250.000 e 1:25.000.

e) Consulta bibliográfica específica sobre os temas tratados.

\subsection{Trabalhos de campo}

a) Levantamento geológico de 30 seções, algumas delas previamente selecionadas a partir da análise bibliográfica e foto-interpretativa, para 
amostragem e confecção de perfis estratigráficos e de um mapa geológico do $C^{\circ}$ Pululus em escala 1:100.000;

b) Confecção de perfis de detalhe das seções mais representativas caracterizando as diferentes unidades vulcânicas presentes e determinando, no campo, suas variações faciais, composicionais, texturais, de espessura e de alteração.

c) Coleta de 44 amostras de rocha para posteriores estudos em laboratório.

\subsubsection{Dificuldades encontradas}

O projeto inicial do trabalho de campo incluía uma maior amostragem das porções centrais do cerro, assim como do setor leste (incluindo perfis SE e NE). Houve, contudo, dificuldades para completar esse projeto devido a vários fatores. A altitude do cerro entre 4.200 e $5.100 \mathrm{msnm}$, por exemplo, tornou as caminhadas muito desgastantes, sendo necessária, em algumas ocasiões, a utilização de um veículo com tração nas quatro rodas para percorrer até mesmo curtas distâncias.

O clima instável, com tempestade e neve (característicos de montanhas de altitude), também foi outro fator que prejudicou o cronograma de atividades a serem realizadas no campo.

Nas porções leste e sudeste, o acesso não foi possível devido aos estreitos vales cavados por drenagens (com paredes que superam $50 \mathrm{~m}$ de altura) e à vegetação rasteira que acompanha essas drenagens, típica de terrenos alagados, localmente denominados "vegas".

A ausência de caminhos também foi um fator que prejudicou o acesso a regiões mais distantes. A partir do mapa de pontos (Anexo II) observa-se que a maior concentração de dados foi tomada na porção oeste do cerro às margens da Laguna Vilama, devido à maior proximidade da estrada.

\subsection{Análises de laboratório}

\subsubsection{Análise petrográfica e contagem modal}

Foram confeccionadas 45 seções delgadas normais para o estudo petrográfico detalhado dos fragmentos de púmice e da matriz do ignimbrito. Nesta análise, identificaram-se os principais minerais, bem como seus aspectos texturais e 
sua relação com as fases acessórias. Além disso, também foram caracterizadas as texturas vulcanoclásticas e os processos pós-deposicionais que afetaram a rocha. Para essas observações utilizou-se microscópio óptico da marca Olympus BXP-50. As fotomicrografias foram obtidas por meio dos fotomicroscópios ópticos Zeiss Axioplan e Olympus BXP-50, com câmera instalada da marca Olympus C5050, pertencentes ao Laboratório de Microscopia Petrográfica (LMP) do Departamento de Mineralogia e Geotectônica (IGc-USP).

As quantificações modais foram obtidas pela contagem de minerais e fragmentos piroclásticos em seções delgadas de púmices e rocha total, obtendo-se, assim, a proporção entre fenocristais versus matriz vítrea do púmice para o primeiro e fragmentos piroclásticos versus matriz do ignimbrito para o segundo. Foram contados entre 1.500 a 2.000 pontos por lâmina, a partir de uma malha $0,3 \times 0,3 \mathrm{~mm}$ instalada no microscópio binocular da marca Leitz Ortholux.

\subsubsection{Análises dos minerais por microssonda eletrônica}

As análises químicas quantitativas do plagioclásio e de minerais máficos foram efetuadas no Laboratório de Microssonda Eletrônica do Departamento de Mineralogia e Geotectônica (IGc-USP). O objetivo dessas análises foi caracterizar quimicamente esses minerais, identificando-os e analisando-os segundo suas feições indicativas de dissolução, reabsorção, zoneamento etc.

O equipamento utilizado foi um JEOL JXA-8600, provido de cinco espectrômetros de dispersão de comprimento de onda (WDS), cada qual com dois cristais analisadores. As seções delgadas polidas foram metalizadas com carbono em câmara de vácuo.

As determinações quantitativas dos elementos foram feitas com $15 \mathrm{kV}$-de voltagem de aceleração e $20 \mathrm{nA}$ de corrente do feixe eletrônico, e com diâmetro variável de $\leq 10 \mu \mathrm{m}$ para plagioclásio e $\leq 5 \mu \mathrm{m}$ para minerais máficos (anfibólio, piroxênio e micas), com tempos de integração de contagens entre 10 e 30 segundos. Foram realizadas correções de efeito de matriz (número atômico, absorção de massa e fluorescência secundária) com o procedimento PROZA.

Os erros máximos estimados variam entre 1 e $2 \%$ para os elementos maiores, $5 \%$ para os menores (1-3\% em peso de elemento) e $10 \%$ para os elementos traços ( $<1 \%$ em peso do elemento). 
As 8 amostras analisadas foram selecionadas a partir de um detalhado estudo petrográfico e correspondem a 6 púmices pertencentes às diferentes unidades estudadas, a 1 amostra de fragmento lítico e 1 amostra do corpo intrusivo.

Em cada uma dessas seções polidas escolheu-se de cinco até dez cristais representativos de cada mineral. Nos cristais zonados ou que apresentam variabilidade textural selecionaram-se, em média, três pontos, representativos de núcleo, porção intermediária e borda. Nos cristais limpos e sem zoneamento foi analisado apenas um ponto localizado no centro dos grãos.

Para tratamento dos dados e apresentação dos diagramas e tabelas das composições químicas foram utilizados os programas Minpet 2.02 (de autoria de Linda R. Richard, 1995), Corel Draw ${ }^{\circledR} 12$ (2003) e Microsoft Excel ${ }^{\circledR}$ (Office 2003).

\subsubsection{Química das rochas}

As análises de geoquímica foram realizadas nos laboratórios do Departamento de Mineralogia e Geotectônica (IGc - USP). Entre um total de 19 amostras analisadas temos 14 amostras de púmices (para palavras em negrito, ver glossário do Anexo I), 3 amostras da matriz, 1 amostra de fragmento lítico e 1 amostra do corpo intrusivo.

Depois de selecionadas, as amostras passaram por um processo de limpeza, para retirada de toda a parte alterada. Nas rochas mais afetadas por processos de soldamento os fragmentos de púmice tiveram de ser cuidadosamente separados, para evitar qualquer contaminação da matriz.

As amostras foram então pulverizadas (pó de, aproximadamente, 200 mesh), com a ajuda de um moinho de anéis de ágata do tipo planetário, e em seguida micronizadas, com um micronizador de cilindros de ágata.

Para a determinação dos elementos maiores $\left(\mathrm{SiO}_{2}, \mathrm{Al}_{2} \mathrm{O}_{3}, \mathrm{TiO}_{2}, \mathrm{MnO}, \mathrm{MgO}\right.$, $\mathrm{CaO}, \mathrm{Na}_{2} \mathrm{O}, \mathrm{K}_{2} \mathrm{O}, \mathrm{P}_{2} \mathrm{O}_{5}, \mathrm{Fe}_{2} \mathrm{O}_{3}$ ), traços ( $\mathrm{Ba}, \mathrm{Cl}, \mathrm{Co}, \mathrm{Cr}, \mathrm{Cu}, \mathrm{F}, \mathrm{Ga}, \mathrm{Nb}, \mathrm{Ni}, \mathrm{Pb}, \mathrm{Rb}, \mathrm{S}$, Sc, Sr, Th, U, V, Y, Z, Zr) e terras raras ( $\mathrm{La}, \mathrm{Ce}, \mathrm{Nd}$ ) pelo método de Fluorescência de raio-X, foi necessária a preparação de duas pastilhas para cada amostra. A pastilha prensada, obtida com a adição de parafina e uma prensa de $30 \mathrm{~T}$, foi preparada no Laboratório de Preparação de Amostras (LTA-DMG) e é necessária para determinar os elementos traços e terras raras. Enquanto a pastilha fundida, obtida por meio da adição de LiBo4 (tetra e metaborato de lítio) como fundente, foi preparada no Laboratório de Química do DMG e é utilizada para determinar os elementos maiores. 
Os resultados das análises foram obtidos pelos técnicos do Laboratório de Florescência de Raio-X.

As análises de elementos traços ( $\mathrm{Ba}, \mathrm{Cs}, \mathrm{Nb}, \mathrm{Pb}, \mathrm{Rb}, \mathrm{Sr}, \mathrm{Ta}, \mathrm{Th}, \mathrm{U}, \mathrm{Y})$ e elementos terras raras ( $\mathrm{La}, \mathrm{ce}, \mathrm{Pr}, \mathrm{Nd}, \mathrm{Sm}, \mathrm{Eu}, \mathrm{Gd}, \mathrm{Tb}, \mathrm{Dy}, \mathrm{Ho}, \mathrm{Er}, \mathrm{Tm}, \mathrm{Yb}, \mathrm{Lu}$ ) determinadas por ICP-AES, foram obtidas pelos técnicos do Laboratório de Química e ICP-AES, mediante o espectrômetro de emissão atômica com plasma induzido (ICPAES), modelo ARL-3410, da Applied Research Laboratories. 


\section{Terminologia, Classificações e Conceitos Utilizados no Relatório}

Neste capítulo estão expostos alguns conceitos e classificações sobre a geração e o depósito de fluxos ignimbríticos. A terminologia mais especifica utilizada no texto (destacada em negrito) encontra-se no glossário do Anexo I.

\subsection{Ignimbritos}

O uso correto do termo ignimbrito é um pouco controverso. Alguns pesquisadores utilizam o termo no sentido litológico, referindo-o a todo tufo-soldado. Outros têm utilizado o termo no sentido genético, referindo-se aos depósitos de fluxo piroclástico. No entanto, a definição mais aceita está de acordo com a definição de Cas e Wright (1987), segundo a qual "ignimbrito é a rocha ou depósito formado a partir de uma ou mais unidades de fluxo piroclástico pumício (pumice-flow), independentemente de estar ou não soldado". Os fragmentos de púmice e líticos podem apresentar tamanhos variados e estão imersos em uma matriz vulcanoclástica de fração cinza e lapilli-fina.

\subsection{Fragmentos Piroclásticos}

Segundo Cas e Wright (1987), são os produtos resultantes da fragmentação do magma e das paredes da rocha encaixante durante uma erupção explosiva. Os fragmentos são classificados quanto ao seu tamanho (cinza, lapilli, bomba - ver dimensões abaixo) ou quanto a sua origem (Juvenis, Cristaloclastos e Líticos, ver glossário).

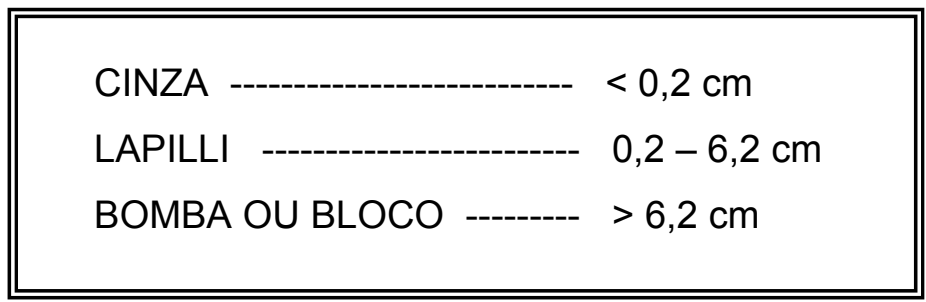

\subsection{Fluxos Piroclásticos}

Fluxos piroclásticos são correntes densas, quentes, parcialmente fluidificadas (com alta concentração de partículas) e pouco turbulentas. São geradas pelo colapso de plumas vulcânicas plinianas (plumas de grande magnitude e intensidade) e 
caracteristicamente, apresentam uma grande quantidade de fragmentos juvenis. Segundo Wilson e Houghton (2000), os fluxos podem ser altamente variáveis quanto ao seu volume $\left(<0,1\right.$ a $\left.>1000 \mathrm{~km}^{3}\right)$ e distâncias percorridas $(<1$ a $>100 \mathrm{~km})$. A velocidade desses fluxos pode alcançar $300 \mathrm{~m} / \mathrm{s}$ e a distribuição é controlada principalmente pela topografia, depositando-se em vales adjacentes ao vulcão.

\subsubsection{Fluxos Piroclásticos de púmice e Depósitos}

Fluxo piroclástico de púmice, ou fluxo ignimbrítico, é a denominação dada às correntes de densidade piroclástica que apresentam mais de $30 \%$ de púmice. Os depósitos são maciços e mal selecionados e estão constituídos por fragmentos de lapilli-púmice (ocasionalmente blocos $>1 \mathrm{~m}$ de diâmetro) imersos numa matriz de partículas vítreas (glass-shards), cristaloclastos e púmices menores que $2 \mathrm{~mm}$ (fração cinza).

Caracteristicamente os depósitos apresentam uma coloração que varia de rosa-salmão a cinza e uma estrutura interna maciça (sem estratificações). Podem, além do mais, apresentar uma grande variabilidade quanto ao grau de soldamento, tamanho e tipo de clastos, geometria do depósito e resposta ao controle topográfico (FREUNDT et al., 2000).

\subsubsection{Dinâmica de Transporte e Deposição}

O fluxo ignimbrítico, assim como outro fluxo qualquer, apresenta uma dinâmica interna de transporte que influenciará nas características do depósito.

Ele é dividido em cabeça, corpo e cauda (Figura 1a) e cada uma dessas partes apresenta diferentes estados de fluidificação que desenvolverão diferentes estratos no depósito, com ou sem a presença de fácies.

Uma típica seção desses depósitos, constituída por 3 (três) camadas principais, é descrita a seguir (Figura 1b), conforme a definição de Sparks, Self e Walker (1973):

i. A porção mais basal do perfil (1) não está necessariamente presente em todos os ignimbritos e é interpretada como um depósito de surge, que se forma na cabeça do fluxo piroclástico, local em que ocorre uma maior interação com a superfície do terreno, além de uma intensa entrada de ar (FREUNDT et al., 2000);

ii. A camada mais espessa (2b) constitui o depósito do corpo principal de um fluxo piroclástico. Está caracterizada por apresentar uma gradação granulométrica 
inversa de púmices (e conseqüente enriquecimento destes fragmentos no topo devido a sua baixa densidade) e uma gradação normal de líticos (com conseqüente concentração dos mesmos na base devido a sua alta densidade);

iii. A camada (2a) representa uma pequena concentração de um fino material piroclástico. Seu contato com a camada (2b) pode ocorrer de forma gradativa a brusca;

iv. A camada do topo (3), denominada depósito de nuvem de cinzas ou ash-cloud surge, raramente é preservada nos depósitos. Está constituída por um fino material juvenil de fração cinza que se deposita a partir do processo de queda (ver queda piroclástica no glossário), podendo também apresentar evidências de transporte lateral.



Figura 01. Associação entre: a) esquema de uma coluna eruptiva com geração de fluxo piroclástico (adaptado de FISHER, 1979) e b) esquema de um depósito piroclástico (adaptado de SPARKS et al., 1973). 1. ground surge (cabeça do fluxo); 2. corpo principal do fluxo piroclástico; 3 . nuvem de cinzas.

\subsubsection{Classificação dos depósitos ignimbríticos}

Foi a partir das diferentes características de colocação dos diversos fluxos piroclásticos que Walker (1983) caracterizou dois tipos principais de depósitos ignimbríticos (Figura 02): 
a) Tipo HARI (hight-aspect ratio ignimbrites): controlado pela topografia, deposita-se passivamente no fundo de vales e resulta em espessos depósitos, com possível zoneamento de soldagem (ver próximo item 3.4);

b) Tipo LARI (low-aspect ratio ignimbrites): gerado por um evento cataclísmico, seus fluxos podem ultrapassar barreiras topográficas e rios a altas velocidades, o que resultará em depósitos mais extensos, com pouca espessura e maior soldamento.

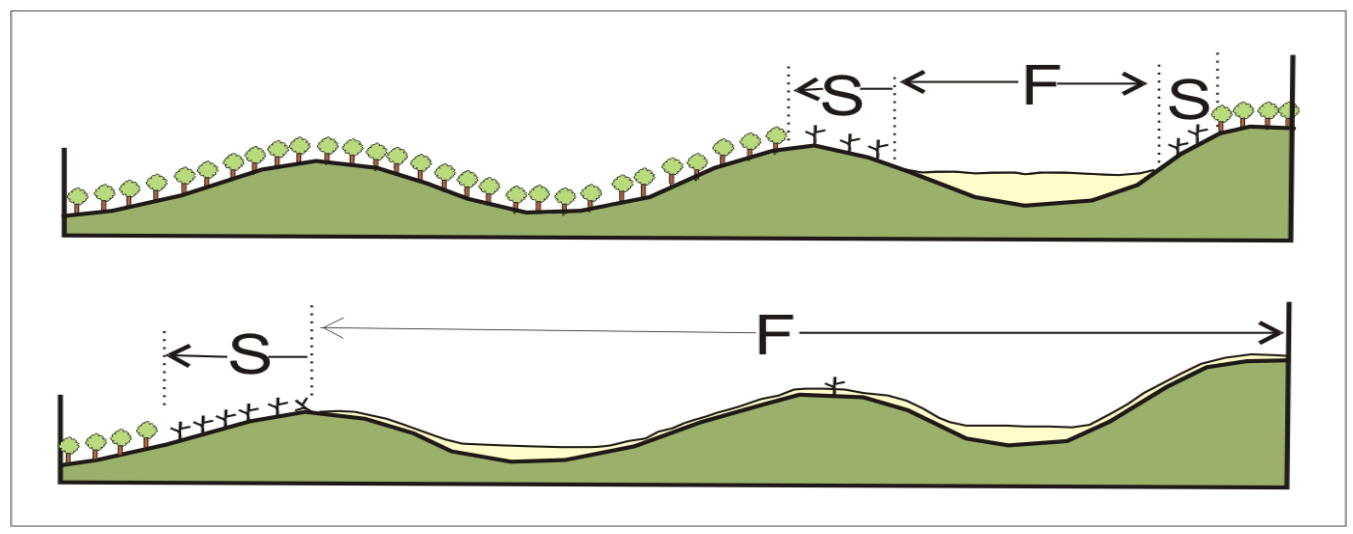

Figura 02. Figura esquemática que contrasta as diferenças entre os depósito do tipo HARI (acima) e LARI (abaixo). F= fluxo piroclástico; S=surge. Adaptado de Walker (1983).

\subsection{Soldamento e Processos pós- deposicionais}

Soldamento é o processo de coesão e deformação do material piroclástico depositado a altas temperaturas e com uma carga sobre-imposta (FREUNDT et al., 2000).

A partir do conceito de que a soldagem é inversa a porosidade, o grau de soldamento da rocha será definido pela relação média do comprimento $(\mathrm{cm})$ versus altura $(\mathrm{cm})$ de púmices observados no depósito:

Ignimbrito NÃO SOLDADO = 1:1 a 2:1

Ignimbrito com SOLDAMENTO INCIPIENTE ou de BAIXO GRAU = 2,5:1 a 3:1 Ignimbrito com SOLDAMENTO MODERADO ou de MÉDIO GRAU = 3,5:1 a 5:1 Ignimbrito DENSAMENTE SOLDADO ou de ALTO GRAU $=>5,5: 1$ 
Em ignimbritos de composição cálcio-alcalino é necessária uma temperatura mínima entre 500 e $650^{\circ} \mathrm{C}$ para que ocorra o soldamento. O soldamento não é uniforme em todo o depósito e pode ocorrer dentro de zonas (Figura 03), associada também a outros processos pós-deposicionais, tais como desvitrificação, reomorfismo e alteração fase-vapor.

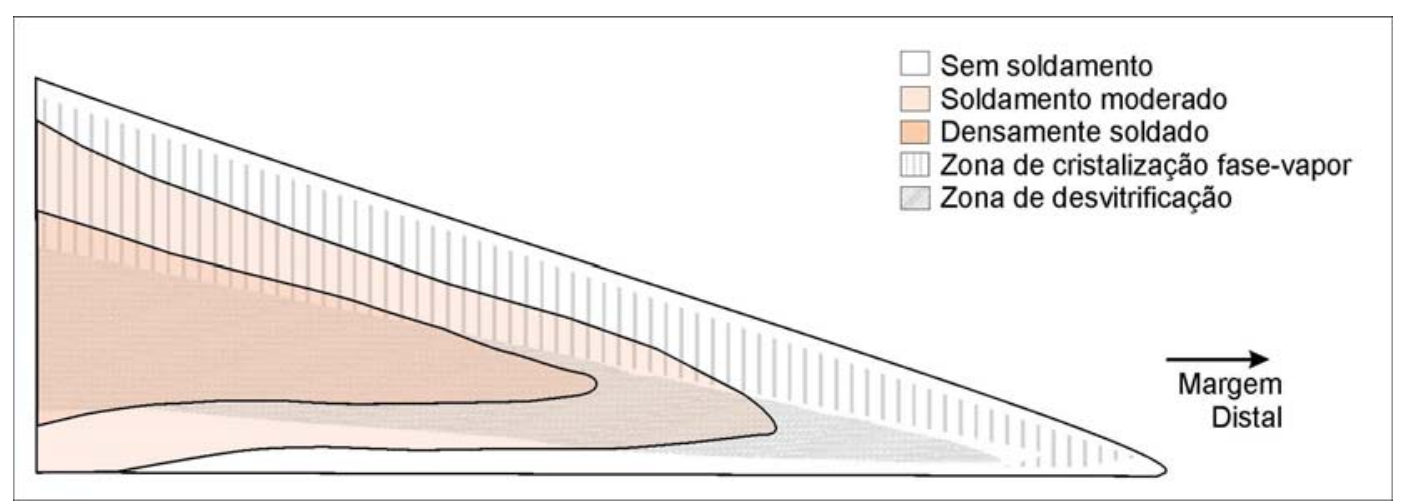

Figura 03. Figura esquemática (perfil) das zonas de soldamento e processos associados em unidade simples de resfriamento (SMITH, 1960). 


\section{Geologia Regional}

\subsection{Zona Vulcânica Central dos Andes (ZVC)}

A Cordilheira dos Andes é aceita na literatura como o melhor exemplo de orogenia e província vulcânica associada a ambientes de subducção. Estende-se por mais de $4500 \mathrm{~km}$ ao longo da costa oeste da América do Sul e divide-se em quatro zonas vulcânicas principais (Figura 04): Norte $\left(5 \mathrm{~N}^{\circ}-2^{\circ} \mathrm{S}\right)$, Central $\left(14-28^{\circ} \mathrm{S}\right)$, Sul $\left(33^{\circ}-\right.$ $\left.46^{\circ} \mathrm{S}\right)$ e Austral $\left(49^{\circ}-52^{\circ} \mathrm{S}\right)$.

A Zona Vulcânica Central (ZVC) apresenta um vulcanismo ativo desde o Jurássico ( $\pm 200 \mathrm{Ma}$; de SILVA e GOSNOLD, 2007) e abrange os territórios a sul do Peru, norte do Chile, sudoeste da Bolívia e noroeste da Argentina, com um magmatismo do tipo silícico de composições andesíticas a riolíticas.

Seu atual arco vulcânico está constituído por uma cadeia de estratovulcões ativos localizados na face oeste da Cordilheira dos Andes, $120 \mathrm{~km}$ acima da placa subductada e a 240-300 km a leste da trincheira de subducção (MATTIOLI et al., 2006).

A leste do atual arco localiza-se uma extensa região vulcânica que apresentou atividade entre o Mioceno e Plioceno, também pertencente a ZVC e denominada por De Silva (1989a) como Complexo Vulcânico Altiplano-Puna (CVAP).

\subsection{Altiplano-Puna}

Altiplano e Puna são as denominações conferidas a duas províncias geológicas que compõem uma elevada altiplanície entre as latitudes $15^{\circ} \mathrm{S}$ e $27^{\circ} \mathrm{S}$ dentro da ZVC (Figura 05). A altiplanície se estende do sul do Peru ao norte da Argentina, com aproximadamente $2.000 \mathrm{~km}$ de extensão e $300 \mathrm{~km}$ de largura. Sua altitude média é de 3.500 a 4.000 msnm e devido a isso a ZVC é considerada como o mais alto platô do mundo associado à magmatismo de arco e o segundo, ficando atrás apenas do Tibet, quanto à altura e extensão (de SILVA e FRANCIS, 1991; ALLMENDINGER et al., 1997; LINDSAY et al., 2001a,b).

As duas províncias, porém, se diferenciam tanto nas feições topográficas e magmáticas, assim como nas estruturas litosféricas e nos seus estágios evolutivos. Elas estão separadas por uma zona de transição de direção NW-SE (Figura 05), delimitada entre $23-24^{\circ} \mathrm{S}$ na parte oriental (margem oeste dos Andes) e entre $20-21^{\circ} \mathrm{S}$ 
na porção ocidental (ao longo do arco magmático principal; ALLMENDINGER et al., 1997), local em que ocorre uma importante mudança na geometria de subducção da placa de Nazca, por baixo da região.

Estudos de sísmica de refração e banda larga passiva revelaram que a ZVC apresenta uma crosta excepcionalmente espessa, estimando-se espessuras de 42 a $66 \mathrm{~km}$ para a crosta abaixo da Puna e de 62 a $80 \mathrm{~km}$ para o Altiplano (YUAN et al., 2002), além de ângulos de subducção que variam entre $25^{\circ}$ e $30^{\circ}$ na latitude $24^{\circ} \mathrm{S}$ (CAHILL e ISACKS, 1992; GUTSCHER et al., 2000).

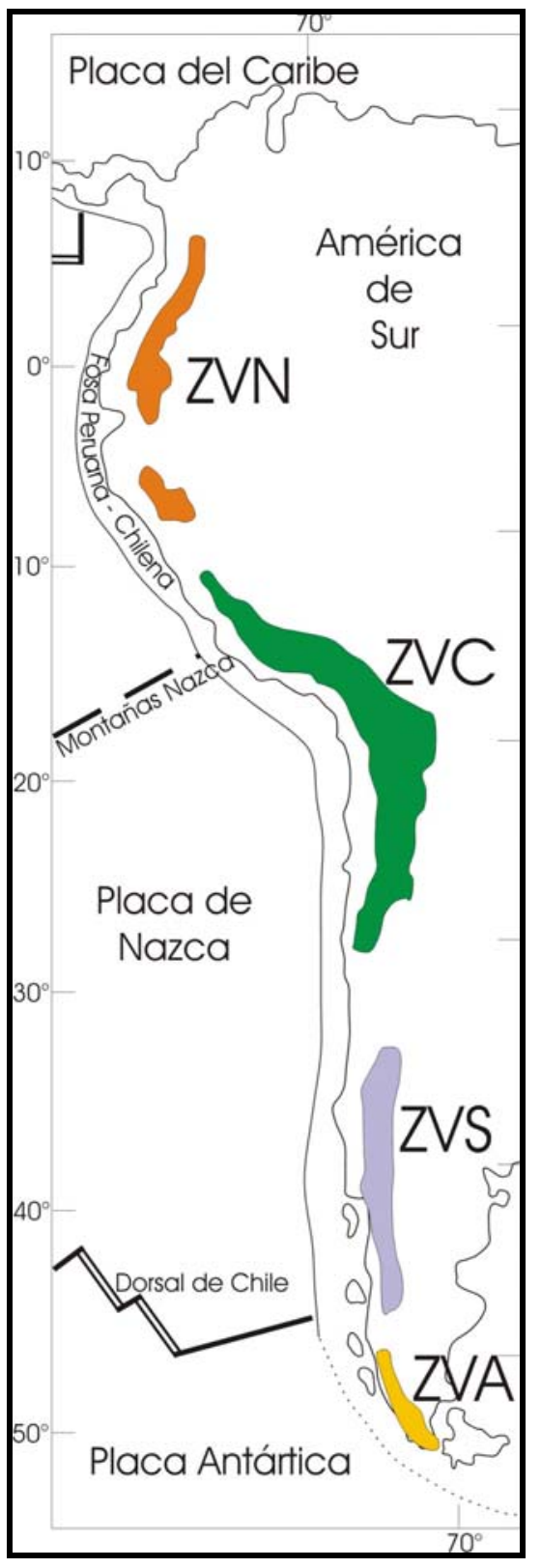

Figura 04. Mapa esquemático da margem oeste da Placa Sul-americana, indicando as 4 zonas vulcânicas ativas dos Andes Centrais: Norte (ZVN), Central (ZVC), Sul (ZVS) e Austral (ZVA).

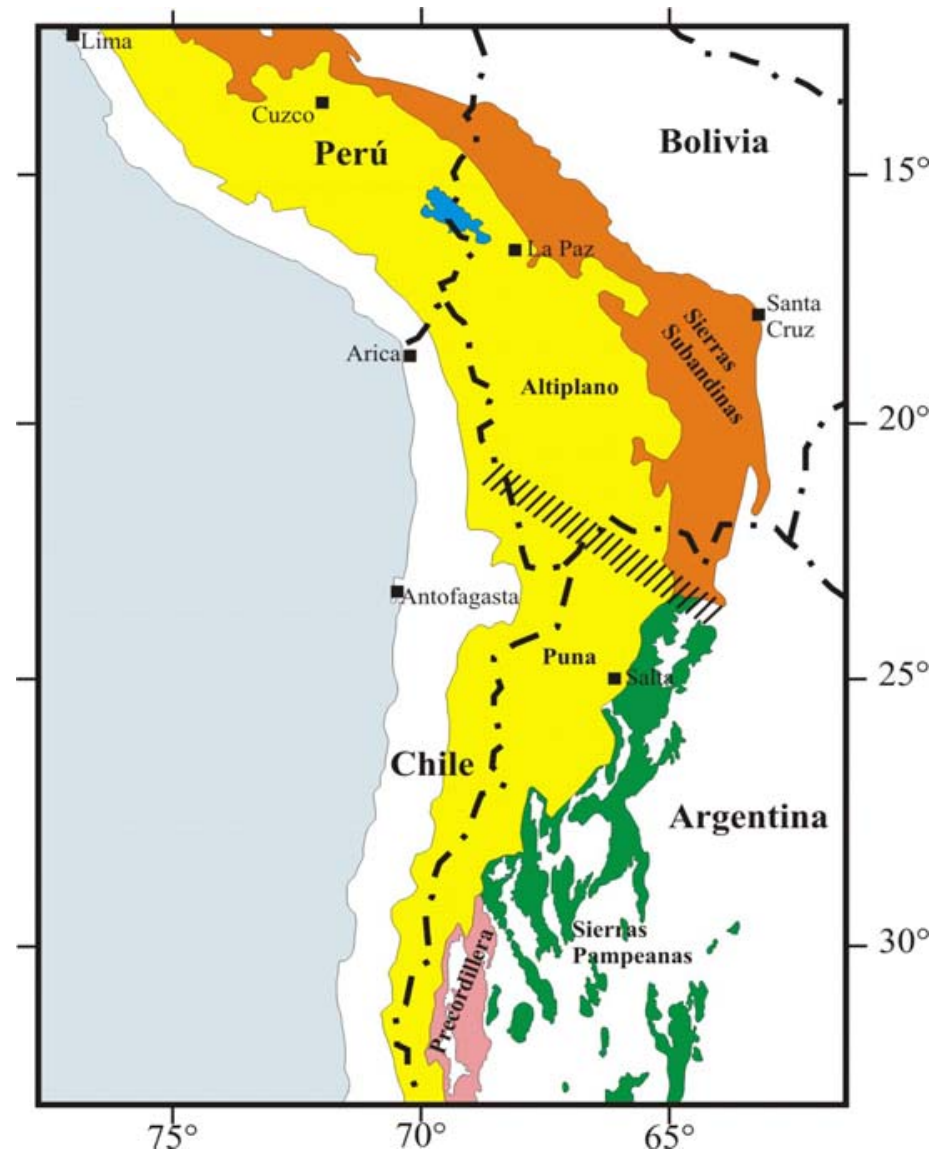

Figura 05. Mapa esquemático de localização nos Andes Centrais do Platô Altiplano-Puna (de cor amarela), definida entre 15 e $27^{\circ} \mathrm{S}$ com uma altitude média de $3700 \mathrm{msnm}$. O setor listrado que cruza o platô, com direção NW-SE, separa a Puna do Altiplano (adaptado de ALLMENDINGER et al., 1997). 


\subsection{Evolução tectônica e sedimentação da Puna Setentrional}

O embasamento que aflora na região da Puna Norte, onde está situado o Cerro Pululus, é constituído principalmente por sedimentos marinhos ordovicianos (Fm. Acoite), caracterizados por Bahlburg (1990) como turbiditos de águas profundas. Rochas de origem vulcânica e, em menor proporção, plutônica ocorrem intercaladas a esses sedimentos e sua origem pode estar associada a um episódio de fechamento de uma bacia essencialmente intracratônica (COIRA et al., 1999).

Registros sedimentares e magmáticos do Paleozóico Superior ao Jurássico estão praticamente ausentes na Puna Norte.

Depósitos sedimentares do Cretáceo (Grupo Salta) ocorrem de forma localizada no noroeste da Argentina e sul da Bolívia e correspondem a eventos de transgressão e regressão marinha numa bacia intracratônica. Eventos extensionais no fim do Cretáceo favoreceram a formação de um rift de retroarco na região.

O início do Paleógeno é marcado pela primeira grande "crise tectônica", denominada Fase Incaica. Esta fase é caracterizada como um evento compressivo regional, que determinou na região a primeira formação de grandes bacias de antepaís à leste da frente de deformação e do arco ativo dos Andes Centrais.

A sedimentação dessas bacias de antepaís teve seqüência durante todo o Paleógeno (JORDAN e ALONSO, 1987) até que se iniciaram, como resultado do repentino aumento no ângulo de subducção da placa de Nazca por baixo da placa Sulamericana, os eventos compressionais mais importantes que afetaram a região e que favoreceu o desenvolvimento da Cordilheira central andina, deslocando o arco vulcânico para oeste.

Segundo Coira et al. (1993), as rochas ígneas geradas a partir desse momento podem ser agrupadas em quatro fases magmáticas (26-18 Ma; 18-10 Ma; 10-3 Ma; 1 Ma-atualidade), separados por três grandes eventos de deformação: Fases Pehuenche, Quechua e Diaguita.

O primeiro destes eventos (Fase Pehuenche) ocorreu entre o Oligoceno Superior e Mioceno Inferior, e teria afetado o Altiplano entre 25 e 18 Ma (KAY et al., 1994), finalizando-se na Puna a aproximadamente 16 Ma (Kay et al. 1994) com importantes eventos compressivos e transcorrentes, associados a um vulcanismo com afinidades alcalinas (SOLER et al., 1993; ALLMENDIGER et al., 1997).

Posteriormente, do Mioceno Inferior ao Médio (18-10 Ma), eventos vulcânicos ocorreram na região na forma de domos e centros subvulcânicos dacíticos (ex. Pan de

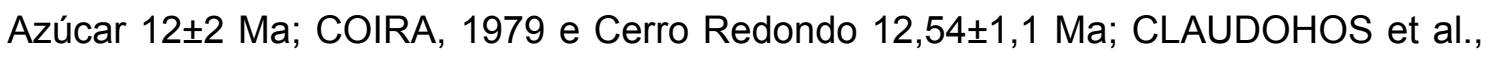


1994) associadas ao preenchimento sedimentar de bacias contemporâneas. Gangui (1998) sugere que nesse período também houve uma intensa atividade tectônica compressiva no norte da Puna, devido a presenças de estruturas tectônicas sinsedimentares, dobras e cavalgamentos.

Durante a Fase Quechua (11-8 Ma), ocorrem os maiores episódios de encurtamento e engrossamento crustal na altiplanície dos Andes Centrais em resposta ao crescente aumento do ângulo de subducção da Placa de Nazca sob a região (ISACKS, 1988; COIRA et al., 1993; ALLMENDINGER et al., 1997). Concomitantemente, entre 12-8 Ma, desenvolveu-se uma importante superfície de erosão regional, denominada Superfície San Juan del Oro (GUBBELS et al., 1993), que serviu de base para os depósitos de imensos fluxos ignimbríticos que extravasaram de grandes caldeiras durante o Mioceno Superior (CVAP), incluindo o $C^{\circ}$ Pululus, objeto deste presente estudo.

O fim do evento Quechua, aprox. $8 \mathrm{Ma}$, é marcada por mudanças na direção de tensão e deformação de um regime compressional para um estado distensivo, conhecida como Fase Diaguita.

A única mudança tectônica posterior ocorreu na forma de uma elevação isostática regional, há cerca de 2 Ma. Gubbels et al. (1993) creditam esse levantamento a um baixo-escorregamento isostático do Cráton Brasiliano que submerge sob as Serras sub-andinas e parte da cordilheira Oriental. Já Somoza (1996) atribui o alçamento a um fenômeno de diminuição da velocidade de colisão entre a Placa de Nazca e a Sul-americana.

O levantamento do segmento do Altiplano no elevado terreno andino tem sido progressivo desde o Oligoceno Superior (29-25 Ma) até o Mioceno (10-6 Ma). Em contraste, no segmento da Puna o encurtamento não se iniciou antes dos 15-20 Ma e teve continuidade até o Plioceno Inferior (1-2 Ma; ALLMENDIGER et al., 1997). Esse diacrônismo, entre o Altiplano e a Puna, reflete as variações do ângulo de subducção da placa de Nazca ao longo do orogeno e das características litosféricas entre as duas regiões (mencionadas no item 4.2).

\subsection{Complexo Vulcânico Altiplano Puna (CVAP)}

De Silva (1989a) definiu o Complexo Vulcânico Altiplano Puna (Figura 06) como uma imensa província vulcânica silícica que cobre uma área de $70.000 \mathrm{~km}^{2}$, com um volume mínimo de $10.000 \mathrm{~km}^{3}$ e idade de 20 a $1 \mathrm{Ma}$, estando delimitada na ZVC entre as latitudes $21^{\circ}$ e $24^{\circ} \mathrm{S}$. 
A origem desse complexo (CVAP) está relacionada com um magmatismo cálcio-alcalino de retroarco, que, sob influência de um regime de subducção de ângulo crescente (Fase Quechua), gerou intensos episódios vulcânicos explosivos na região da Puna e partes do Altiplano boliviano e resultou na formação de um enorme complexo de caldeiras e estratovulcões e na deposição de uma das mais extensas, volumosas e bem expostas províncias ignimbríticas do mundo (GUEST, 1969; PICHLER e ZEIL, 1972; De SILVA, 1989a; De SILVA e FRANCIS, 1991; LINDSAY et al., 2001; De SILVA, et al., 2007).

Geoquimicamente, as rochas do CVAP são homogêneas, de composição principalmente dacítica e em menor proporção riolítica e andesítica (de SILVA,1989; de SILVA e FRANCIS, 1991). Diversos autores (e.g. de SILVA, 1989a,b; LIDSAY et al., 2001; SCHIMITT et al., 2001, CAFFE et al., 2002) creditam a origem dos magmas que alimentaram as erupções do CVAP durante o Mioceno Superior e Plioceno como resulltante da mistura, em diferentes proporções, de fusões provenientes do manto com material crustal.

Recentemente, diversos experimentos geofísicos têm revelado detalhes da estrutura crustal sub-vulcânica do CVAP, confirmando a contribuição de uma fusão da crosta continental em grande escala para geração destes magmas (SCHNURR et al., 2007; SILVA et al., 2007).

Chmielowski et al. (1999), Zandt et al. (2003) e Leiding and Zandt (2003) identificaram, a partir de estudos de sísmica, a presença de uma espessa camada, de aproximadamente $2 \mathrm{~km}$, que apresenta baixíssima velocidade de propagação de ondas e está localizada logo abaixo do CVAP, entre 17 e $19 \mathrm{~km}$ de profundidade. Outros pesquisadores, como Springer (1999) e Brasse et al. (2002), identificaram no mesmo local uma extensa superfície com alto fluxo de calor e alta condutividade, atribuindo essas propriedades a um imenso corpo de magma (like-sill) parcialmente fundido (Altiplano Puna Magma Body - APMB, CHMIELOWSKI et al., 1999; ZANDT et al., 2003).

\subsubsection{Caldeiras do CVAP}

Foi apenas entre as décadas de 1970 e 1980, com uma maior aplicação de imagens Landsat, que diversas caldeiras dentro da região do CVAP puderam ser reconhecidas e subseqüentemente descritas (de SILVA, 1989b; de SILVA e FRANCIS, 1989; LINDSAY et al., 2001), entre elas podem-se citar Cerro Panizos (ORT, 1996), La 


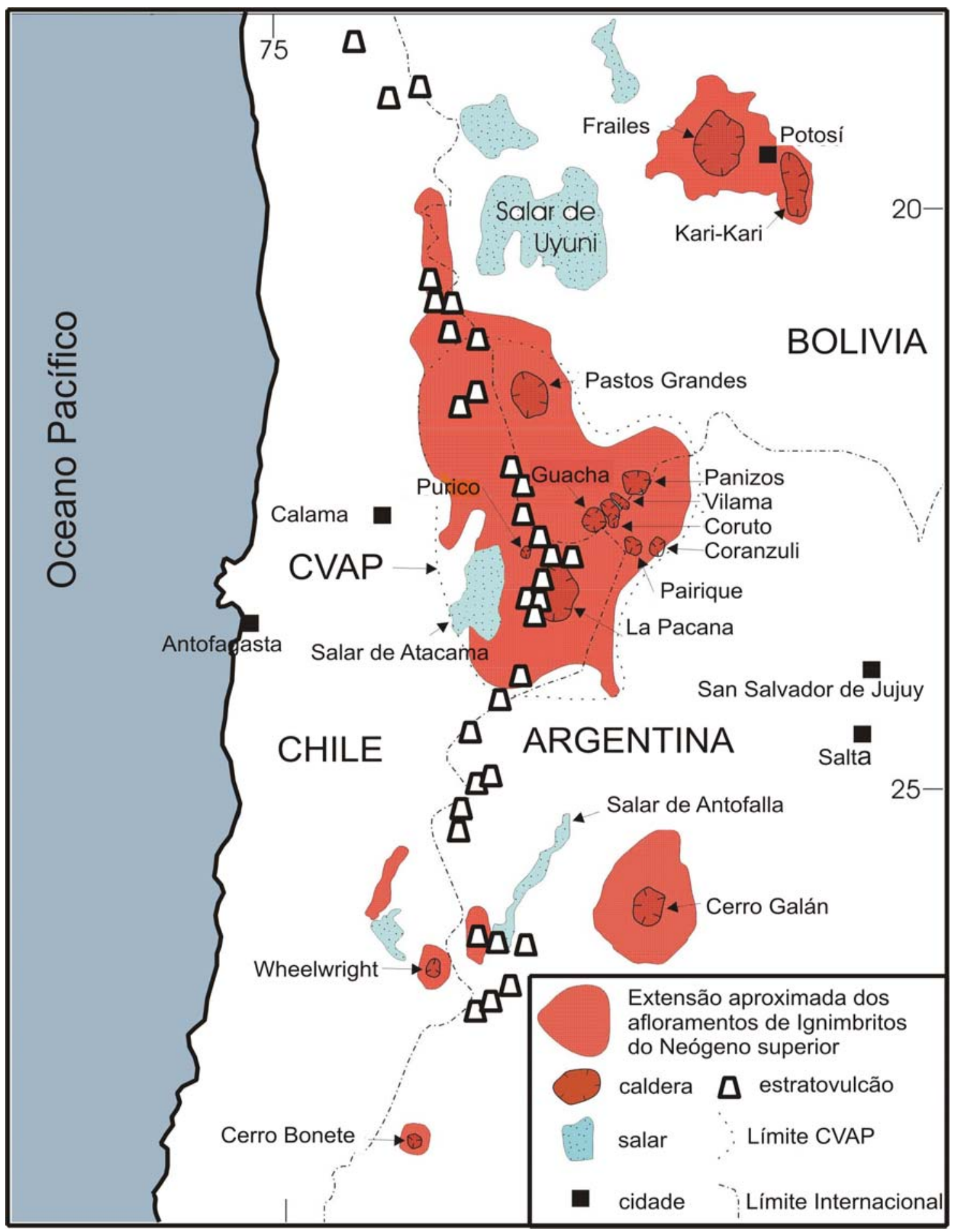

Figura 06. Mapa esquemático da área abrangida pelo Complexo Vulcânico Altiplano-Puna (CVAP) dentro da Zona Vulcânica Central (ZVC). O esquema também apresenta a extensão aproximada dos afloramentos ignimbriticos depositados durante o Neógeno Superior e as principais caldeiras vulcânicas do Complexo (adaptado de SILVA e FRANCIS, 1991). 
Pacana (GARDEWEG e RAMIREZ, 1987; LINDSAY et al., 2001a,b; SCHMITT et al., 2001, 2002), Complexo Vilama e Coruto (COIRA et al., 1996; SOLER, 2005; SOLER et al., 2007), Pairique e Coranzuli (SEGGIARO, 1994), além de Cerro Gaúcha e Pastos Grandes, Kari-Kari, Archibarca, Wheelwright e Águas Calientes, que ainda não foram estudadas (Figura 06).

Estas caldeiras estão caracterizadas como enormes centros vulcânicos de longa-vida que geraram continuadamente grandes fluxos piroclásticos púmiceos (ignimbrites flare-up) e que estão localizadas paralelamente ao arco vulcânico atual, ou em canais transversais que cruzam o platô.

Um dos maiores problemas para o estudo destas caldeiras é que as correlações de seus depósitos são incompletas, principalmente porque a maioria desses ignimbritos de grandes volumes exibe características de campo similares e eles geralmente se apresentam intercalados devido a sua contemporaneidade.

\subsubsection{Ignimbritos do CVAP}

Os ignimbritos desse complexo variam de idade entre 20 e $1 \mathrm{Ma}$, sendo que as erupções de maior volume, ignimbritos flare-up, ocorreram nos últimos 10 milhões de anos.

A composição dacítica rica em cristais $\left(63-68 \% \mathrm{SiO}_{2}\right)$ é volumetricamente dominante nesses ignimbritos, com volumes que superam $9000 \mathrm{~km}^{3}$ (i.e. $90 \%$ dos $10.000 \mathrm{~km}^{3}$ respectivos ao flare-up (SILVA et al., 2007)). Já os ignimbritos de composição riodacítica e riolítica são raros em meio a esses depósitos, correspondendo a 6 e 1,2\%, respectivamente, do volume total estimado. Em termos de volume, as intercalações de composições andesíticas são insignificantes (SILVA, 1989a; SILVA e FRANCIS, 1991; LINDSAY et al., 2000; COIRA et al., 1993; SILVA et al., 2007) e devido a essa homogeneidade composicional os depósitos do CVAP foram denominados como "monotonous intermediate" por Silva e Francis (1991).

Em um dos seus mais recentes trabalhos sobre o CVAP, de Silva et al. (2007) sugerem que o magma dacítico é remanescente do grande batólito APMB (Figura 07), atribuindo-Ihe uma composição andesítica.

Segundo os autores, as fusões, provenientes do batólito, foram armazenadas em grandes câmaras magmáticas instaladas em níveis mais rasos da crosta (entre 4 e $8 \mathrm{~km}$ de profundidade), logo abaixo do CVAP. As sutis diferenças encontradas entre os distintos depósitos ignimbríticos, tais como variações nas concentrações de ETR e 
na química dos minerais, evidenciam que cada magma, correspondente a um ignimbrito, evoluiu dentro de um reservatório individual antes que ocorra a erupção.

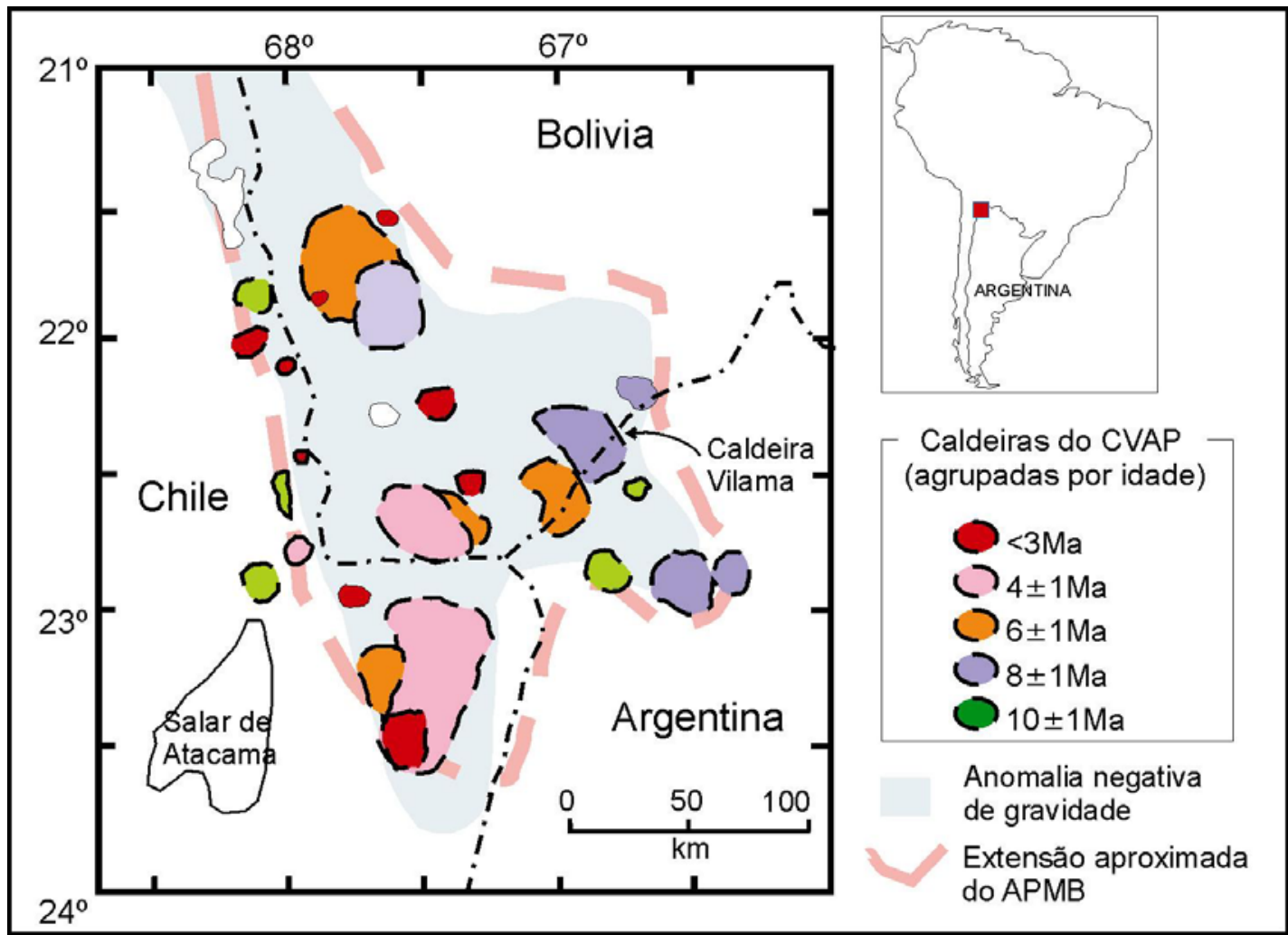

Figura 07. Extensão aproximada do APMB, segundo SILVA et al. 2007, estimada a partir da correlação entre a área que engloba as caldeiras do CVAP e área que apresenta anomalias negativas de gravidade e de baixa velocidade sísmica entre 17 e $19 \mathrm{~km}$ de profundidade. Para identificação das caldeiras ver Figura 06.

Quanto aos ignimbritos dacíticos de menor volume do CVAP, Silva e Francis (1991), devido a sua variação textural e composicional, mencionaram que não parecem apresentar relação com as típicas morfologias de caldeira e os interpretam como produtos gerados por pequenas câmaras magmáticas zonadas.

\subsection{Complexo de Caldeiras Vilama-Coruto}

A caldeira Vilama é uma das maiores estruturas caldéricas conhecidas no CVAP e sua origem está associada a uma das maiores emissões piroclásticas que ocorreu no platô dos Andes Centrais, com volumes que superam $1200 \mathrm{~km}^{3}$ (SOLER et al., 2005).

Coira et al. $(1996 a, b)$ foram os primeiros a descrever e interpretar a origem e evolução da Caldeira Vilama, diferenciando e caracterizando 3 distintas etapas evolutivas para o complexo de caldeiras ao qual ela pertence (Complexo de Caldeiras 
Vilama-Coruto - CCVC) que teriam começado a se desenvolver a partir do Mioceno Superior.

Segundo os autores, a Caldeira Vilama (estrutura de $65 \times 40 \mathrm{~km}$, localizada a $22^{\circ} 36^{\prime} \mathrm{S}$ e $66^{\circ} 51^{\prime} \mathrm{W}$; Figura 08a) foi gerada por duas etapas principais de colapso. $\mathrm{O}$ primeiro colapso (trap-door collapse) estaria associado ao Ign. Granada (que abrange uma área de $2.300 \mathrm{~km}^{2}$ ) e o segundo (down-sag collapse) à emissão do lgn. Vilama (ocupando uma área total $<2.700 \mathrm{~km}^{2}$ ). Para os autores a emissão dos fluxos piroclásticos Pululus teria ocorrido na $3^{a}$ etapa, com seu centro de emissão subparalelo às estruturas de colapso da caldeira e vinculadas a um domamento ressurgente do ignimbrito homônimo (de orientação NW). Nessa etapa, também se construiu o centro vulcânico andesítico Zapaleri, além de outras emissões menores de lavas de composições dacíticas e riolíticas (cerros Maria Bonita e Solterío e domo Caucaní), que, assim como Pululus, acompanham o sistema de fraturas anelares da caldeira (COIRA et al., 1996a).

Recentemente, Soler (2005) e Soler et al. (2007) redefiniram a área e a localização da Caldeira Vilama, reduzindo seu tamanho para uma estrutura de $35-40 \mathrm{x}$ $15-18 \mathrm{~km}$, com coordenadas centrais em $22^{\circ} 24^{\prime} \mathrm{S}$ e $66^{\circ} 57^{\prime} \mathrm{W}$ e orientação de seu maior eixo na direção NW-SE (Figura 08). Os autores consideram que a caldeira foi formada por um único evento de colapso (do tipo piston collapse ou piecemeal collapse), sendo que as margens topográficas apenas aparecem no lado oeste da estrutura.

Soler também ampliou a área de alcance e deposição do Ign. Vilama para $>4.000 \mathrm{~km}^{2}$, redefinindo sua estratigrafia e descartando o Ign. Granada (9,7-9,8 Ma e $860 \mathrm{~km}^{2}$ de área) do novo complexo, agora denominado como Complexo Caldérico Eduardo Avaroa, do qual fazem parte: Caldeira Vilama, Caldeira Coruto (6,2 Ma; SOLER, 2005); COIRA et al, ( 1996a,b; 2004) e Cerro Guacha (6,6-4,2 Ma. SOLER, 2005; e autores citados) (Figura 08b).

\subsubsection{Ign. Vilama}

Como já mencionado, Soler (2005) e Soler et al. (2007) redefiniram a estratigrafia do Ign. Vilama reconhecendo duas unidades de resfriamentos, UEI (Unidad de Esfriamiento Inferior) e UES (Unidad de Esfriamiento Superior). Segundo Soler, a unidade UEl é um depósito maciço, de coloração cinza, com soldamento ausente ou incipiente, com espessuras mínimas de $7 \mathrm{~m}$ e máximas de $110 \mathrm{~m}$. Já o depósito UES é bem mais extenso que o anterior, de aspecto maciço e espessuras que variam de 5 a $60 \mathrm{~m}$. Também apresenta uma marcante variação na cor (rosa, 
marrom claro, marrom-avermelhado), grau de soldamento (moderado a alto), além de uma característica disjunção horizontal e desprendimento em lajes entre a base e o topo do depósito, o que permitiu separar a unidade em UESb (base) e UESt (topo).

Composicionalmente, todas apresentam similares características geoquímicas. São rochas dacíticas, da série cálcio-alcalina rica em potássio, metaluminosas a peraluminosas e com índices A/CNK variando entre 0,90-1,15. Outros detalhes serão apresentados no capitulo 10. 
a)

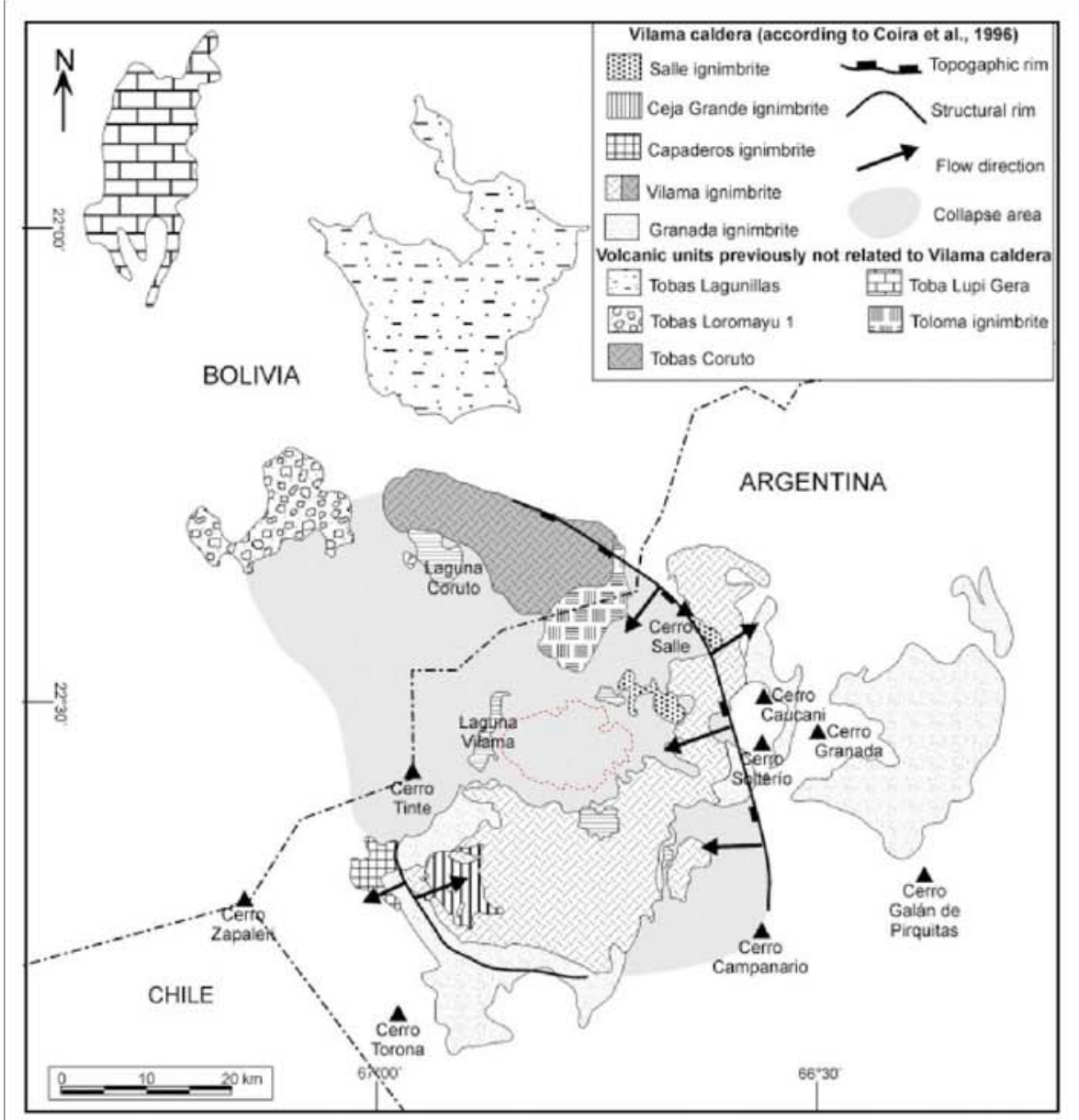

b)

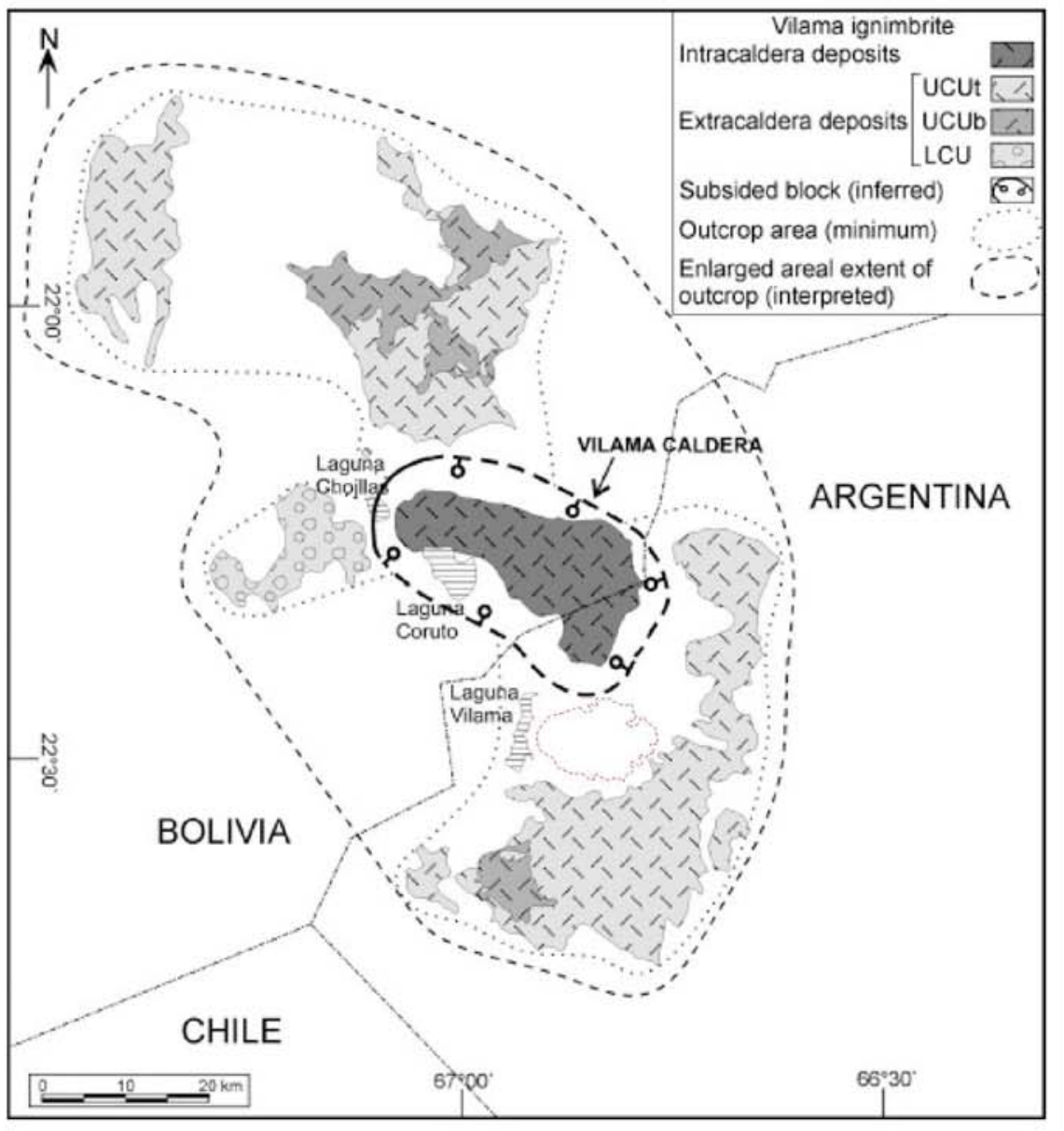

Figura 08. a) Mapa geológico do Complexo de Caldeiras Vilama-Coruto, segundo Coira et al, 1996 (adaptado por SOLER et al, 2007); b) Nova definição de tamanho e localização da caldeira Vilama, e extensão do Ignimbrito Vilama, segundo Soler et al, 2007. O Cerro Pululus em destaque (linha vermelha), localizado a margem direita da Laguna Vilama, não é apresentado nas figuras originais. 


\section{5. Área de Estudo}

\subsection{Localização e Acesso}

O Co Pululus está localizado no departamento Rinconada na província de Jujuy, extremo noroeste da República Argentina, $25 \mathrm{~km}$ a leste da fronteira da República da Bolívia (Figura 09).

O acesso dá-se, a partir da cidade de Abra Pampa, $216 \mathrm{~km}$ ao norte de San Salvador de Jujuy, capital da província. A estrada (rumo a oeste) que leva ao povoado de Rinconada cruza a Serra de Rinconada, o vilarejo de Orosmayo e prossegue até Minas Pirquitas. No seu final, encontra-se a estrada com destino a Abra de Granadas, que dá acesso ao $C^{\circ}$ Pululus e a Laguna Vilama.

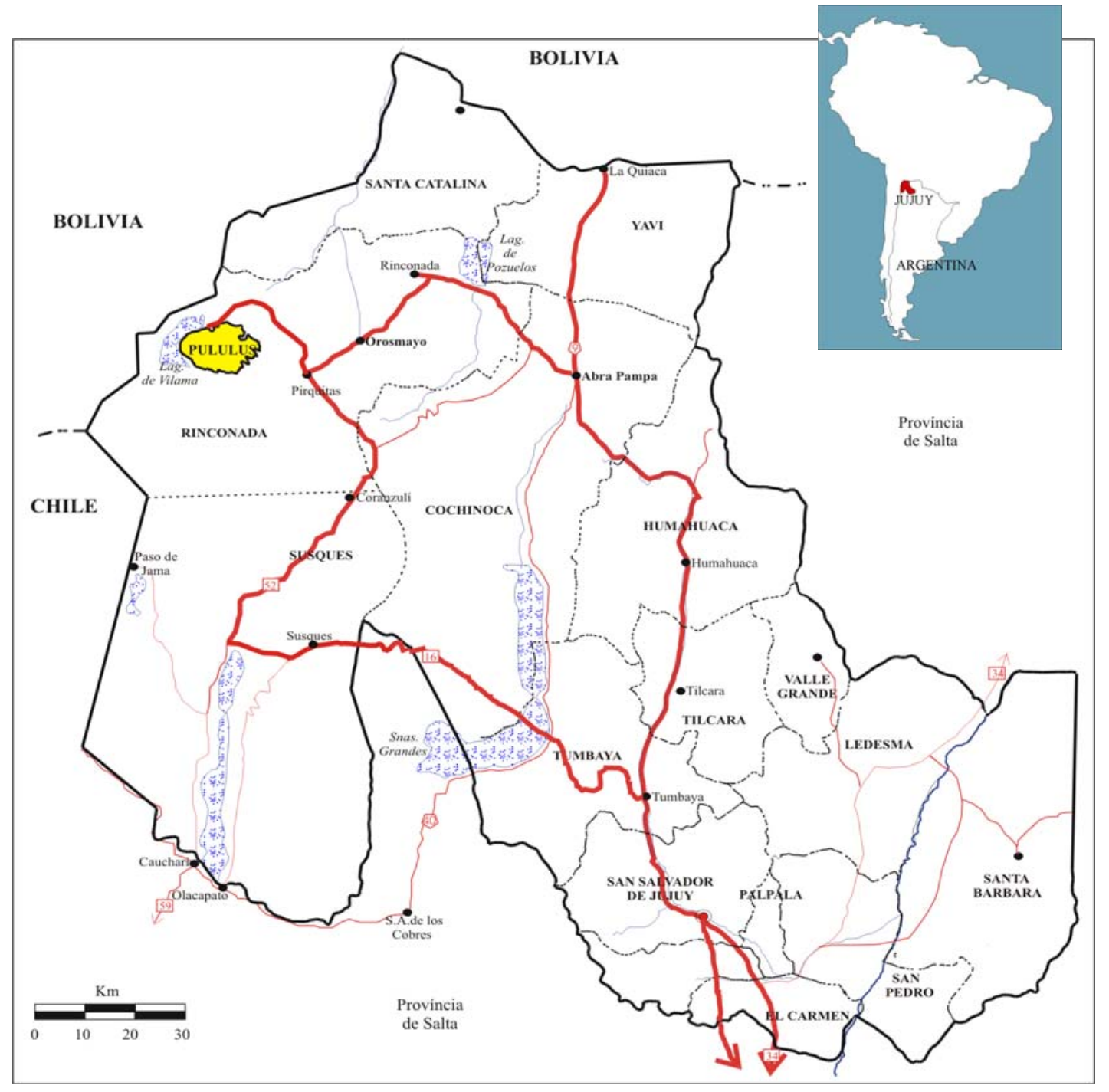

Figura 09. Mapa da província de Jujuy, Argentina, apresentando os caminhos de acesso para chegar ao $\mathrm{C}^{\circ}$ Pululus (destaque em amarelo). 


\subsection{Situação Geológica}

A Província Geológica da Puna à qual pertence o $\mathrm{C}^{\circ}$ Pululus, está limitada a leste pela cordilheira Oriental dos Andes da Argentina (TURNER e MENDEZ, 1979) e a oeste pela cordilheira Ocidental, onde atualmente se encontra a frente do arco vulcânico ativo da CVZ. Geograficamente toda a Puna se caracteriza pelo clima seco e aridez extrema, apresentando temperaturas com grandes amplitudes térmicas diárias e uma rede de drenagem, em geral, centrípeta.

O Co Pululus localiza-se a $22^{\circ} 36^{\prime} S$ e $66^{\circ} 50^{\prime} \mathrm{W}$, apresentando uma área de aproximadamente $150 \mathrm{~km}^{2}$, com $550 \mathrm{~m}$ de altura, a $4.500 \mathrm{~m}$ de altitude (msnm). $\mathrm{O}$ cerro ocupa a porção central de uma depressão a sul da Caldeira Vilama e encontrase cercado por diversas lagunas salgadas, tais como: Laguna Vilama (a oeste), Pululus (a norte) e Palar (a sul). E, mais além (rodeando Pululus e as lagunas), encontra-se uma cadeia de centros vulcânicos andesíticos de idade pleistocênica, constituída pelos cerros Tinte, Zapaleri, Negro, Bravo, Vilama, Salle e Granada (Figura 10). Os mapas geológicos regionais mostram Pululus em contato a leste e sul com o Ign. Vilama, e a norte com o Ign. Salle.

\subsection{Trabalhos Prévios}

\subsubsection{Cerro Pululus}

A primeira citação sobre Pululus aparece na publicação de Sgrosso (1935) sobre jazimentos estaníferos na província de Jujuy. Nesse trabalho, o autor limitou-se a em descrever apenas sobre as mineralizações de cassiterita, fazendo pouca menção às rochas do cerro. Segundo ele, as mineralizações (cassiterita espinhosa e hematita fibrosa e botrioidal) encontram-se em áreas afetadas por fumarolas de altas temperaturas que preencheram as diacláses de resfriamento. Sgrosso contabilizou até 15 veios mineralizados no cerro, todos de posição vertical, com direção geral N5E a N20E e concentrações de até $72 \%$ de Sn (sendo que a média extraída da parte central de cada veio alcança valores de aproximadamente $50 \%$ de $\mathrm{Sn}$ ). Os minerais de ganga são quartzo e óxidos de ferro.

Em 1945 e 1948, Ahlfeld também descreve as mineralizações do Co Pululus em trabalho sobre os jazimentos de estanho no sul da Bolivia e noroeste argentino. Anos depois, o cerro começa a ser incluído em trabalhos de reconhecimento regional. No primeiro deles, Turner (1978) descreve Pululus como parte da Formação Galán 


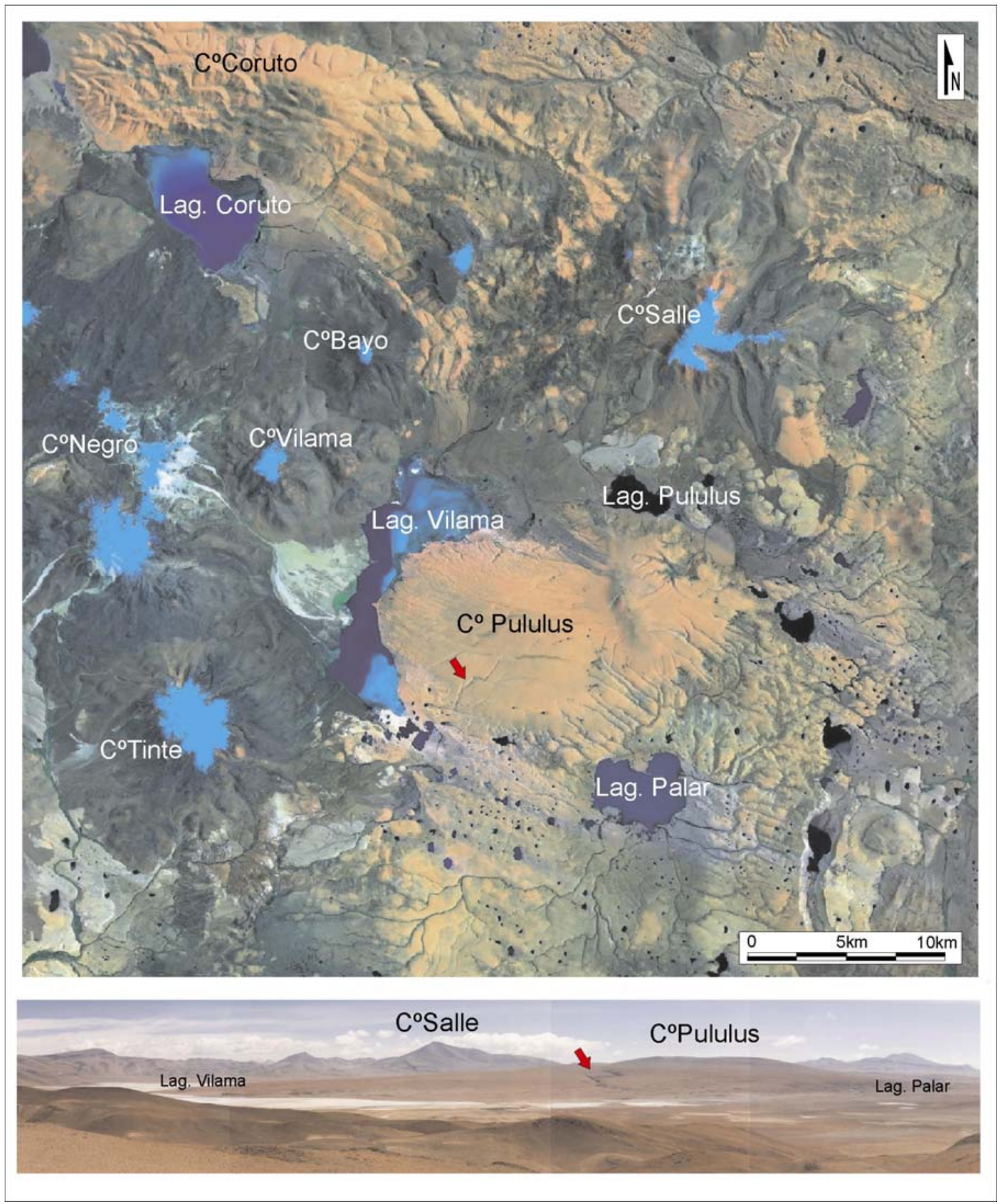

Figura 10. Imagem de satélite e fotomontagem na qual é possível observar a localização e extensão do $C^{\circ}$ Pululus, cercado pelos centros vulcânicos andesíticos. A fotografia foi tirada na ponta NW de Pululus. A seta vermelha, em ambas imagens, foi inserida para referência de localização. Trata-se de um vale profundo e seco (quebrada), desenvolvido ao longo do sistema de fratura de resfriamento dos depósitos do $\mathrm{C}^{\circ} \mathrm{Pululus.}$ Para maiores detalhes sobre geologia ver Figura 08. 
(Plioceno) e o posiciona estratigraficamente acima de duas unidades, hoje conhecidas como ignimbritos Vilama e Salle.

A primeira descrição e delimitação dos depósitos do $C^{\circ}$ Pululus aparece nos trabalhos de Coira et al. (1996a,b). Segundo os autores, os fluxos piroclásticos do $C^{\circ}$ Pululus são caracterizados pela sua coloração rosada, alta porcentagem de cristais (35-40\%), alto grau de soldamento (com desenvolvimento de texturas eutaxíticas), além de uma intensa alteração por processos fumarólicos, e com espessuras decrescentes para as partes mais distais. Também acrescentam que as erupções que geraram tais fluxos apresentaram um baixo conteúdo de gases, assim como uma pouca perda de calor durante a emissão do material vulcânico. No mesmo trabalho, os autores situam Pululus na porção central de uma grande depressão caldérica, relacionado-o com o terceiro ciclo de desenvolvimento do Complexo Caldérico VilamaCoruto (CCVC; Mioceno Superior), como continuação de um vulcanismo pós-colapso que ocorreu durante o Plio-Pleistoceno.

Em trabalho mais recente, Polo (2004) apresenta os resultados do único estudo existente sobre a estratigrafia e petrografia do depósito e oferece um modelo eruptivo para as diferentes unidades que compõe o cerro (descrita no capitulo 10 deste trabalho).

\subsubsection{Unidades do embasamento}

Segundo Coira et al. (1996a), os fluxos púmiceos do $C^{\circ}$ Pululus estão depositados acima de dois importantes depósitos ignimbríticos: o Ign. Vilama, que aflora ao lado de toda a borda leste e sul de Pululus, e o Ign. Salle, depósito afetado por forte soldamento que aflora apenas na porção norte-nordeste, como um braço que se estende por debaixo de Pululus. Considera-se o $C^{\circ}$ Salle como o provável foco de erupção desse ignimbrito (Figura 09).

A sul do $C^{\circ}$ Pululus também foi reconhecido um depósito de fluxo piroclástico de composição riolítica (Polo, 2004), porém sem aparente relação com Pululus ou com o Ign. Vilama (ver localização e descrição do Ponto 11 nos Anexos I e II). 


\section{Estratigrafia do Cerro Pululus}

\subsection{Unidades do Cerro Pululus}

Os trabalhos de campo realizados no $C^{\circ}$ Pululus, em janeiro de 2004, permitiram reconhecer três distintas unidades de fluxo, que corresponderiam a diferentes eventos eruptivos (Figura 11), denominadas:

- Unidade de Fluxo Cinza (UFC);

- Unidade de Fluxo Rosado Inferior (UFRI);

- Unidade de Fluxo Rosado Superior (UFRS).

As localizações dos pontos descritos e amostrados são apresentadas no Anexo II. Os critérios utilizados para a separação das unidades litológicas em campo foram: o índice de cor, o grau de soldamento e a variedade e a quantidade de púmice e de fragmentos líticos (ver descrições de afloramentos no Anexo III).

Uma quarta unidade, denominada neste trabalho como Corpo Intrusivo Pululus (CIP), foi identificada e descrita no ano de 2007 pelos geológos Diego Fracchia e Pablo Caffe, do Instituto de Geologia y Mineria (IdGyM; UNJu - Arg). Tal unidade aflora no alto do cerro e não foi encontrada durante o trabalho de campo realizado em 2004 devido à espessa cobertura de neve que havia na ocasião.

Todos os depósitos piroclásticos do cerro foram afetados por alteração fasevapor e nenhum deles apresenta mudanças significativas entre fácies proximais e distais. Um dos aspectos mais característicos desses ignimbritos é seu elevado conteúdo em cristais, característica também da maioria dos ignimbritos da região vulcânica centro-andina (Sparks et al. 1985).

\subsubsection{Unidade de Fluxo Cinza (UFC)}

Aflora na porção sudoeste do $C^{\circ}$ Pululus, nas margens da Laguna Vilama. $O$ depósito é maciço, de cor cinza-claro, com variações para lilás e creme (em zonas afetadas por alteração fase-vapor ou soldamento). Apresenta um baixo a médio grau de soldamento e uma notável disjunção vertical, com espessuras que variam de 0,8 a $50 \mathrm{~m}$ (decrescentes para sudoeste e sem base aflorante). 


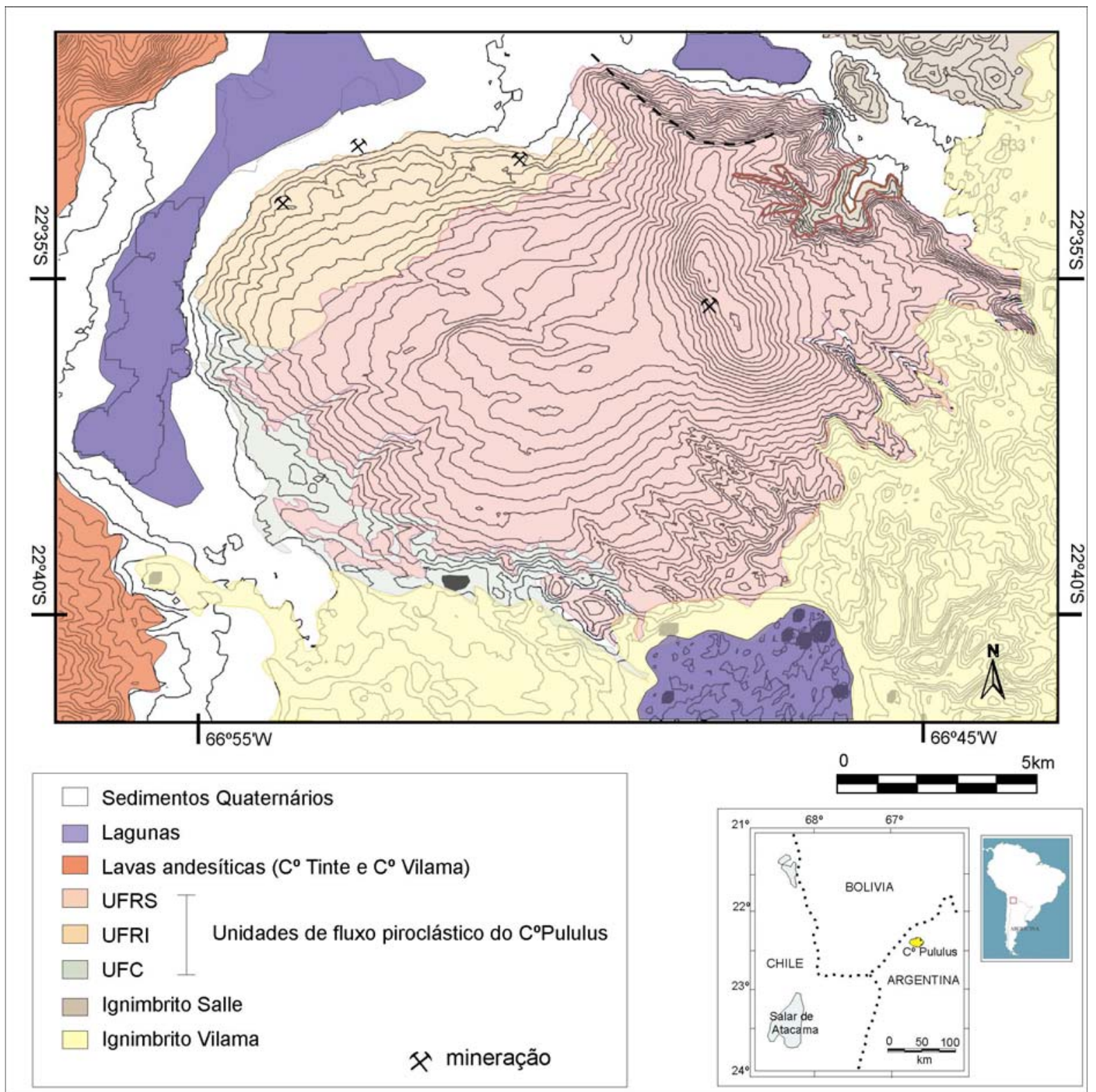

Figura 11. Mapa geológico do Cerro Pululus (adaptado de Polo, 2004) com unidades do embasamento (segundo, Coira et al., 1996) .

No depósito ocorre apenas um tipo de púmice, com diferentes graus de achatamento, e diversos tipos de líticos imersos em uma matriz rica em fragmentos vítreos, cristaloclastos e pequenos púmices na fração lapilli.

Mediante a elaboração de perfis foi possível determinar quatro fácies (1a, 1b, 2 e 3) que apresentam variações significativas quanto à quantidade e tamanho dos púmices e dos fragmentos líticos, assim como o grau de soldamento que afetou cada uma delas (Figura 12):

\subsubsection{Fácies 1a (basal):}


Esta fácies, de coloração creme clara, aflora em uma pequena área ao lado da Laguna Vilama (ver mapa de pontos, Anexo II). O depósito apresenta aproximadamente $10 \mathrm{~m}$ de espessura e está limitado lateralmente por vales cavados pela drenagem de degelo.

Trata-se de um depósito rico em púmices (25 a 30\%) e grandes fragmentos líticos (8-10\%) imersos em uma matriz vulcanoclástica de fração cinza-grossa a lapilli, afetada por um baixo a moderado grau de soldamento (Foto 02). Foram identificados dois tipos de púmices (branco e rosado) com tamanhos que variam de lapilli a blocos de até $23 \mathrm{~cm}$ e um grau de achatamento na ordem de 4:1. Os líticos, de formas tanto angulares como arredondadas, são de origem acidental e acessória (ver lítico no glossário) e correspondem a rochas meta-sedimentares (arenitos) e sub-vulcânicas e vulcânicas do embasamento (dacitos e riolitos porfíriticos e vitrófiros vermelhos), com tamanhos que variam de lapilli $(2 \mathrm{~cm})$ a blocos de até $34 \mathrm{~cm}$ (Foto 03).

\subsubsection{Fácies 1b:}

Este depósito aflora com espessuras de $3 \mathrm{~m}$ até $30 \mathrm{~m}$ e apresenta um baixo grau de soldamento (2:1 - Foto 04). No Perfil 12 observa-se uma gradação normal dos fragmentos líticos, em que blocos de 10 a $25 \mathrm{~cm}$, com formas angulosas a arredondadas, diminuem gradativamente para a fração lapilli $(<3 \mathrm{~cm})$ em direção ao topo, enquanto que suas porcentagens também variam de $<8 \%$ na base para $<2 \%$ no topo (praticamente desaparecendo na porção superior do depósito). Estes líticos são de origem acidental ou acessória e correspondem a fragmentos de rochas metasedimentares e sub-vulcânicas (riolitos porfiríticos avermelhados e a andesitos afaníticos cinza).

Os púmices, por outro lado, apresentam uma gradação granulométrica inversa aumentando de fração lapilli-fina $(<1 \mathrm{~cm})$ na base para blocos de até $30 \mathrm{~cm}$ no topo e concentrações aproximadas de $<15 \%$ na base para $25 \%$ no topo. Exibem formas irregulares, elipsoidais ou arredondados e é possivel observar, em algumas seções, púmices elípticos orientados segundo o seu eixo maior (esta feição porém, não é suficiente para afirmar que a rocha está soldada).

\subsubsection{Fácies 2:}

Esta fácies, de aspecto lajoso (Foto 04), apresenta um alto grau de soldamento $(6,2: 1)$ e espessuras que variam entre 0,5 e $5 \mathrm{~m}$. Os púmices $(25-40 \%)$ exibem uma forma elíptica irregular, ocorrendo nas frações lapilli e blocos, de 5 a 30 $\mathrm{cm}$. Os líticos (5 a 12\%), estão representados por fragmentos de riolitos porfiríticos 


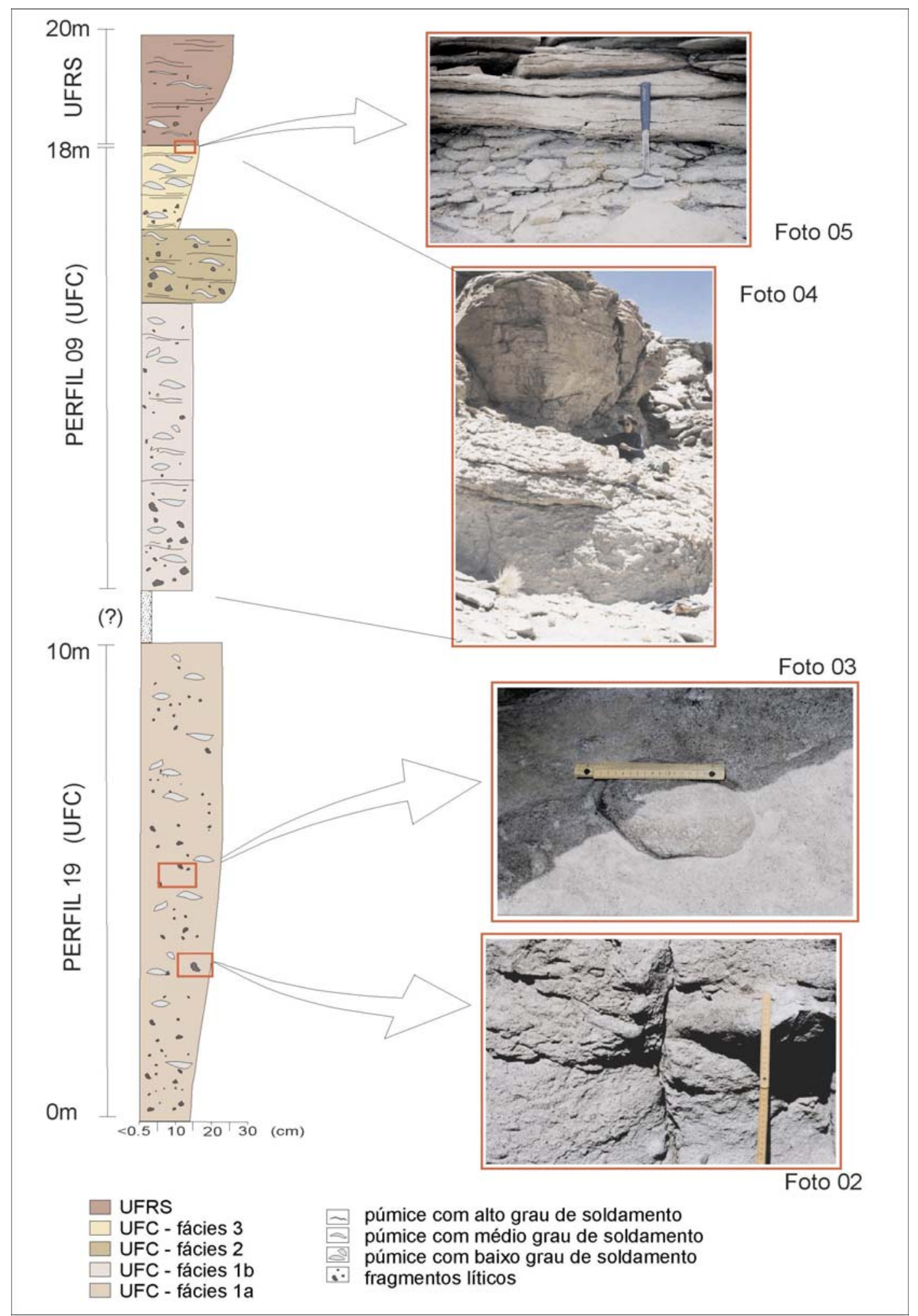

Figura 12. Perfil esquemático dos afloramentos pertencentes à UFC e localizados a oeste do $C^{\circ}$ Pululus (perfis 09 e 19, ver descrição no Anexo III). A escala granulométrica (na base do perfil) refere-se à granulometria dos fragmentos de púmice. Foto 02: Fácies 1a, riqueza em fragmentos líticos. Foto 03: Fácies 1a, fragmento lítico de $34 \mathrm{~cm}$. Foto 04: Contato de Fácies $1 \mathrm{~b}$ (porção inferior da fotografia de tonalidade mais clara) e Fácies 2 (acima, a partir da escala, de cor marrom). Foto 05: Contato da UFC (Fácies 3) com UFRS. 
avermelhados, dacitos porfiríticos cinzas, andesitos afaníticos, vitrófiros e meta-sedimentos ordovicianos, todos com tamanhos inferiores a $5 \mathrm{~cm}$.

\subsubsection{Fácies 3:}

Apesar de apresentar um aspecto mais lajoso que a fácies anterior (Foto 05), seu grau de soldamento não ultrapassa de 3:1 e sua espessura pode variar de menos de $0,5 \mathrm{~m}$ a até $6 \mathrm{~m}$. Esta fácies está coberta pela Unidade de Fluxo Rosado Superior (UFRS; Foto 05), sendo que em apenas um afloramento a UFRI ocorre intercalada a estes dois depósitos (Foto 12 e 13).

Os púmices (15-30\%) voltam a ocorrer em frações menores (até $15 \mathrm{~cm}$ ) e os líticos (5\%) apresentam dimensões que variam entre 1,0 e $10 \mathrm{~cm}$. Estes últimos são de origem acidental e acessória e correspondem a fragmentos de rochas subvulcânicas e vulcânicas (dacitos e andesitos), como também meta-sedimentos (metaarenitos).

\subsubsection{Unidade de Fluxo Rosado Inferior (UFRI)}

Esta unidade ocorre na porção oeste e norte do $C^{\circ}$ Pululus (Figura 11), apresentando uma coloração rosa escura acinzentada, púrpura e cinza rosada (em porções mais frescas e menos soldadas) com espessuras que variam entre 10 e $60 \mathrm{~m}$, sem base aflorante. Contém dois tipos de lapilli-púmices (branco e rosado) e líticos diversos imersos em uma matriz constituída por cristaloclastos (40\%), fragmentos vítreos e pequenos púmices soldados (menores que $1 \mathrm{~cm}$ ).

Os púmices podem apresentar-se soldados, com típicas terminações em chamas que se mesclam à matriz, ou achatados em zonas menos afetadas por soldamento (Foto 06). Blocos líticos angulosos são de origem acidental ou acessória e correspondem, em geral, às rochas metasedimentares e vulcânicas afaníticas do embasamento. Blocos mais arredondados correspondem a fragmentos plutônicos de composição granodioritica (com a mesma assembléia mineral do ignimbrito) e são de provável origem cognata. Outros fragmentos líticos arredondados ocorrem no tamanho de lapilli e correspondem a vitrófiros, dacitos e riolitos porfiríticos, de provável origem acidental (Foto 07).

Nenhuma mudança lateral que possa indicar fácies proximal ou distal foi de fato identificada. No entanto, gradações verticais de tamanho e quantidade de líticos e púmices, assim como variações no grau de soldamento foram observadas em um 


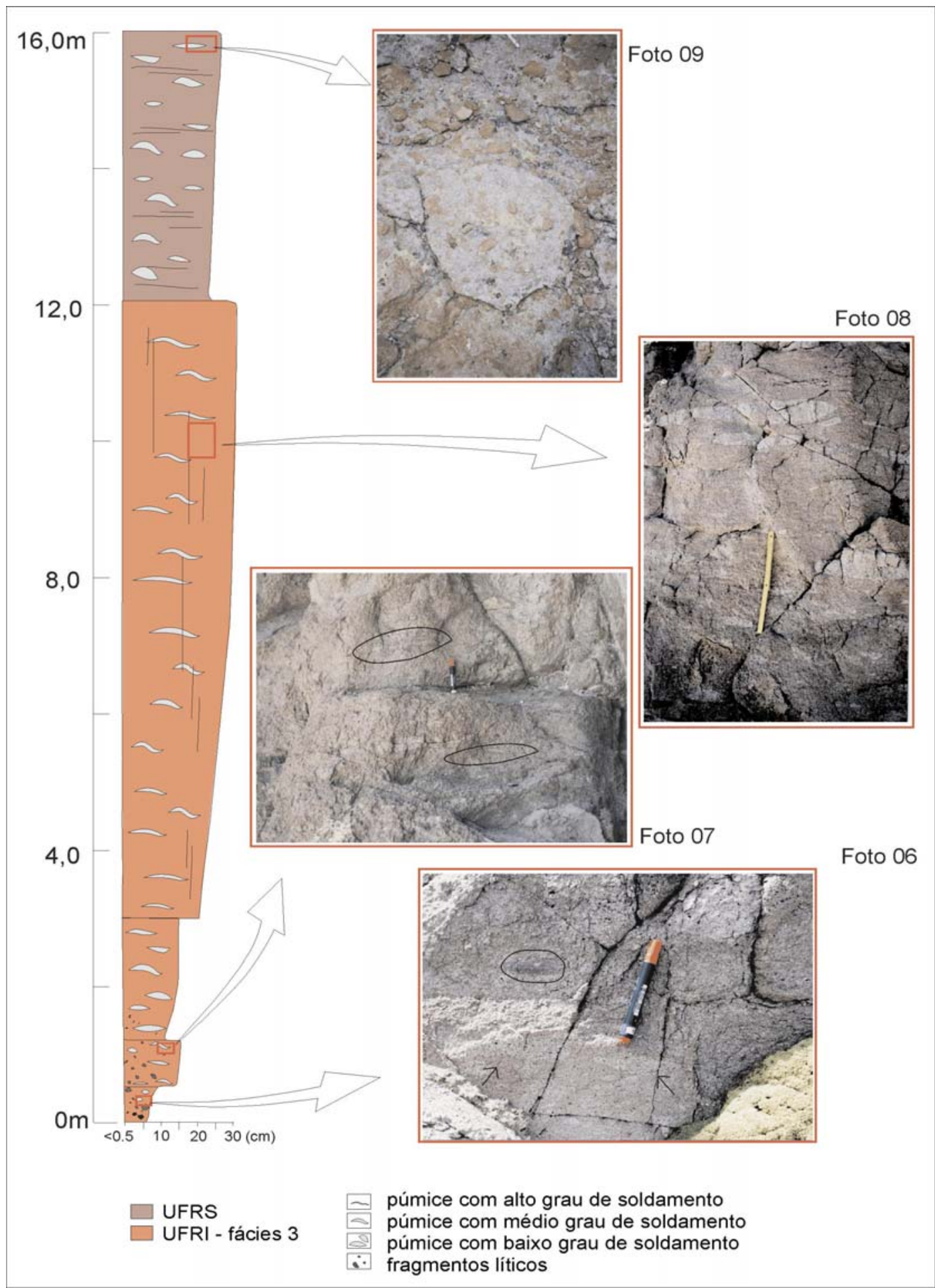

Figura 13. Figura esquemática do perfil 03, com afloramentos da UFRI (laranja) e UFRS (marrom). A figura mostra a variação no grau de soldamento e a maior concentração de líticos na base do perfil. Também se observa uma gradação normal dos líticos e inversa dos púmices da base ao topo do depósito. Foto 06: Fragmento lítico (em destaque no círculo) em meio a grande quantidade de lapilli-púmices (algumas estão indicadas por setas). Foto 07: Lapilli-púmices achatados (com razões de 6:1). Foto 08: Bloco-púmices no topo da UFRI. Notar tamanho de púmice (escala $20 \mathrm{~cm}$ ) e seu alto grau de achatamento. Foto 09: Púmices achatados no topo do perfil (visto em planta), pertencentes à UFRS. Notar o desprendimento dos púmices da rocha. 
mesmo afloramento. Um bom exemplo é o Perfil 03, que para melhor visualização foi esquematizado na Figura 13 (ver descrição completa no Anexo III).

Em outros afloramentos desta mesma unidade não se observou a mesma concentração de líticos na base como no Perfil 03, porém fragmentos líticos na fração lapilli-blocos (de até $40 \mathrm{~cm}$ ) continuam a ocorrer dispersos em todo o depósito, até mesmo na zona de maior soldamento (Foto 08). Blocos de púmices também são freqüentes.

Em algumas seções, como no ponto 23, foram encontrados fragmentos de púmice soldados com razão de $30: 9 \mathrm{~cm}$ (ver descrição completa do afloramento no Anexo III).

No entanto, uma das feições mais interessantes e distintivas desta unidade, assim como da UFRS, é a presença de pequenos fragmentos vermelhos afaníticos, freqüentemente bandados, que ocorrem como fiammes dispersos no depósito (Foto 10). Esses fiammes (Foto 11) foram analisados em lâminas delgadas e poderiam vir a representar fragmentos líticos de rocha piroclástica (tufo) com elevado soldamento e oxidação (descrição petrográfica no Anexo IV).

\subsubsection{Unidade de Fluxo Rosado Superior (UFRS)}

Esta unidade recobre grande parte do cerro, estendendo-se por cima das demais unidades (Figura 11 e 12; Fotos 05, 12 e 13). Apresenta uma coloração rosa cinzenta avermelhada e espessuras que variam entre $3 \mathrm{~m}$, a oeste de Pululus, até 10$15 \mathrm{~m}$, em grande parte do cerro. Nas porções mais superiores do depósito, ou nos locais em que ocorre com menor espessura, apresenta uma marcante e característica lajosidade, de modo que a rocha se desprende em lajes métricas, conforme observado nas fotos 09 e 12.

A matriz é vulcanoclástica, rica em cristaloclastos e pequenos fragmentos de púmice soldados. Os fragmentos líticos representam menos de $2 \%$ do depósito e correspondem a rochas vulcânicas dacíticas e andesiticas afaníticas, blocos de rocha plutônica (granodiorito), pequenos fiammes vermelhos ou fragmentos angulares de tufo oxidado e soldado. Os púmices (15-20\%) variam de pequenos lapilli até blocos de $30 \mathrm{~cm}$ de diâmetro, com uma morfologia preferencialmente elíptica nas zonas de moderado grau de soldamento (4,5:1). Em cortes de afloramento, perpendiculares à direção de soldagem, muitos púmices ficam quase imperceptíveis devido ao seu elevado achatamento, sendo que só é possível observá-los em planta como pequenos "discos" que se despendem da rocha (Foto 09). 


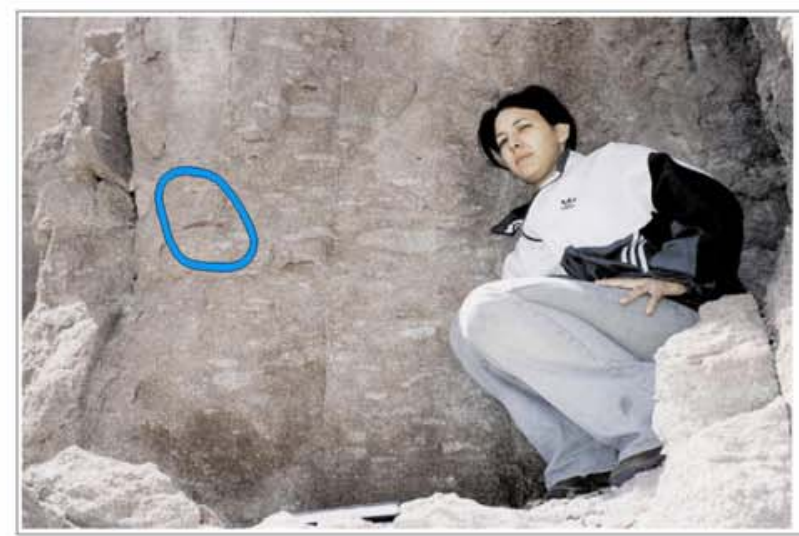

Foto 10

Afloramento da UFRI. Notar

quantidade e diversidade no tamanho

dos púmices. Destaque para o

fiamme vermelho (círculo azul), além

deste também são observados outros

fiammes menores dispersos.

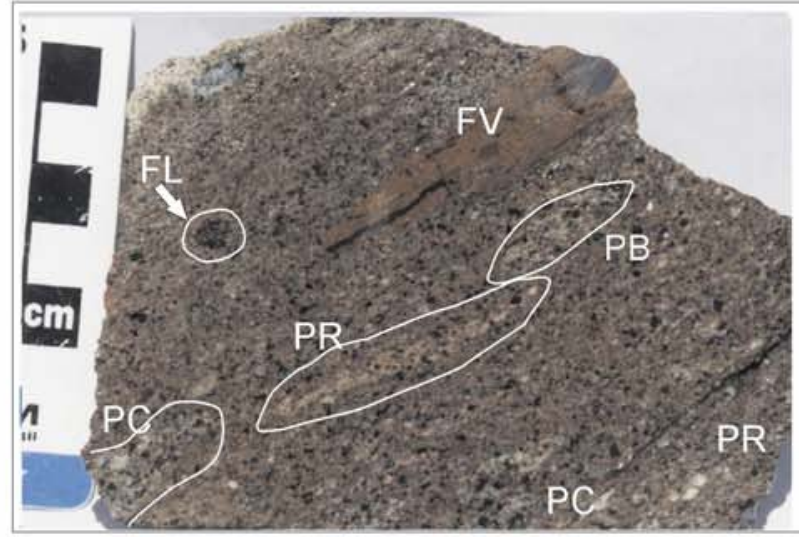

Foto 11

Amostra de mão contendo púmice branco (PB), púmice rosa (PR), púmice cinza $(P C)$, fiamme vermelho $(F V)$ e fragmento lítico (FL).

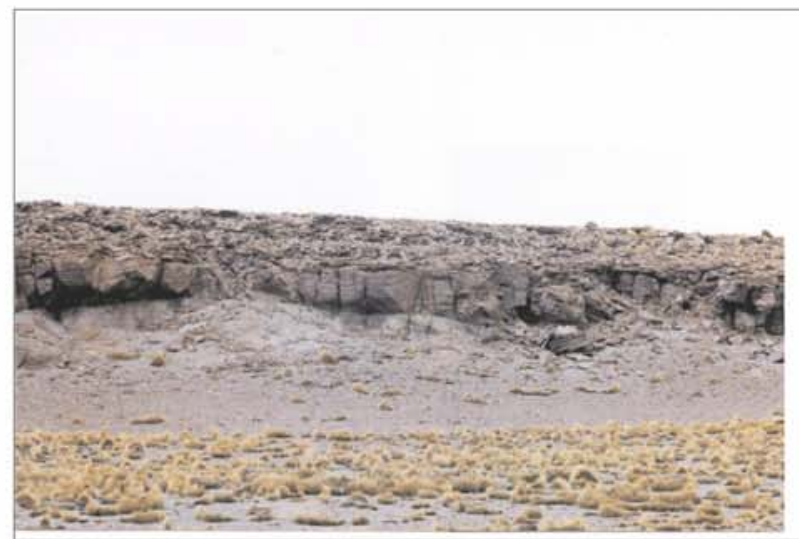

Foto 12

Perfil completo apresentando as três unidades: UFC na base (cinza) sob UFRI (aspecto maciço) e UFRS no topo (aspecto mais lajoso).

Afloramento a oeste de Pululus, as margens da Laguna Vilama.

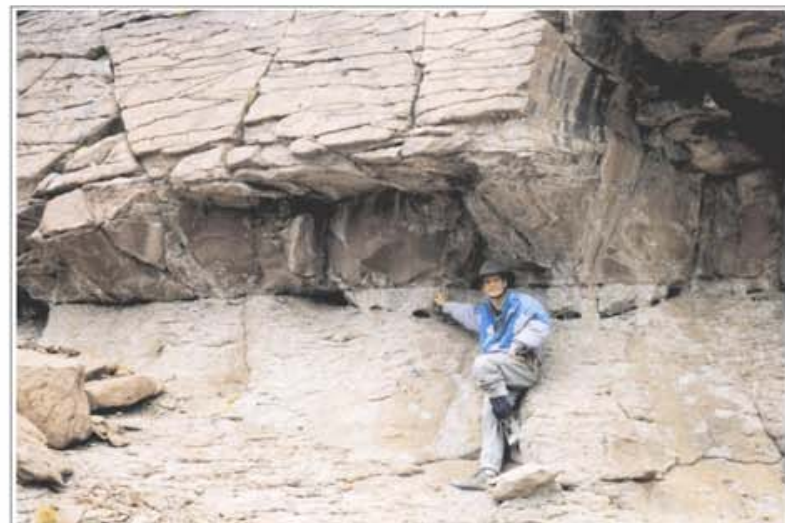

Foto 13

Detalhe do afloramento da foto acima, mostrando contato da UFC com UFRI. 


\subsubsection{Corpo Intrusivo Pululus (CIP)}

Esta unidade é encontrada no cume do cerro intrundindo os depósitos piroclásticos de Pululus. Segundo Fracchia et al. (2008), o afloramento ocorre na forma de um pequeno anticlinal com orientação NNW-SSE e flancos com inclinação $\leq 30^{\circ}$, em que se observa a lava dacítica, na base, e os depósitos piroclásticos de Pululus no teto da dobra. Segundo Fracchia, essa lava pertence a um corpo subvulcânico de grandes dimensões $(8,1 \pm 0,2 \mathrm{Ma})$ que intrudiu e dobrou os ignimbritos de Pululus, conferindo-Ihe a atual forma em escudo. 


\section{Petrografia e Química dos principais minerais}

Todas as unidades ignimbríticas do $\mathrm{C}^{\circ}$ Pululus apresentam, ao microscópio, uma textura vitroclástica desvitrificada, com grau de soldamento baixo a alto, estando, diversas vezes, afetada por alteração fase-vapor e reomorfismo. A assembléia mineralógica do $\mathrm{C}^{\circ}$ Pululus consiste de plagioclásio (40-61\%), biotita (17-30\%), quartzo (9-24\%), ortopiroxênio (<10\%), clinopiroxênio (<4\%) e hornblenda $(<2 \%)$, além de apatita, zircão e opacos como acessórios.

As descrições completas das seções delgadas estudadas são apresentadas no Anexo IV. As análises químicas dos minerais mais importantes encontram-se nas tabelas do Anexo V.

\subsection{Textura das rochas}

Tanto os púmices quanto a matriz dos ignimbritos apresentam altas proporções em cristais (50 a 68\% para púmices e de 23 a $32 \%$ para matriz), sendo que na matriz os cristais ocorrem bem mais fragmentados, o que the confere um aspecto mais sujo quando observado ao microscópio (Foto 14). Nos púmices, os cristais tendem a formar uma textura glomero-porfirítica e, embora a alta vesicularidade seja uma típica característica de púmices, estes apresentam poucas vesículas (entre 0,6 e 12\%).

\subsubsection{Púmices}

Ao microscópio, os pequenos lapilli-púmices dispersos na matriz ocorrem sempre estirados, com terminações e bordas pouco definidas (Foto 14), sendo que, em amostras retiradas de zonas de maior soldamento, os púmices tendem a ocorrer como fiammes. A desvitrificação que afeta os púmices se dá principalmente na forma de esferulitos esféricos (Foto 14). Esferulitos axiolíticos (ver esferulitos no glossário) observam-se apenas em zonas do depósito que foram afetadas por soldamento incipiente e pode ocorrer como contorno de espaços vazios ou ao redor de cristaloclastos (Foto 15).

Seções delgadas realizadas em amostras das unidades UFRI e UFRS revelaram que os púmices brancos e rosas (Foto 11) se diferenciam principalmente quanto ao grau de desvitrificação, sendo que a assembléia mineral não difere entre os mesmos. De tal forma, os fragmentos mais avermelhados apresentam um grau mais 
avançado de desvitrificação, com a formação de diversos esferulitos esféricos dispersos na matriz associados a uma textura micropoiquilítica (ver desvitrificação no glossário). Os púmices brancos, por sua vez, apresentam poucos esferulitos, sempre dispersos.

Também foram analisados os púmices de cor cinza escuro que ao microscópio revelaram uma composição mais máfica e com cristais de granulometria mais fina que as demais amostras (ou seja, os púmices claros). Os principais minerais presentes são plagioclásio (predominantemente labradorita), \pm quartzo, biotita, ortopiroxênio, clinopiroxênio e hornblenda, sendo que todos os máficos, principalmente anfibólio e clinopiroxênio, não ocorrem dispersos, mas concentrados em camadas máficas que caracterizam um discreto bandamento (Foto 16). Nota-se, além disso, que microcristais de plagioclásio $(<0,2 \mathrm{~mm})$ ocorrem associados a essas concentrações máficas que se intercalam a camadas constituídas predominantemente por fenocristais de plagioclásio (aprox. 0,5 mm) e ocasionalmente grandes placas de biotita. A matriz deste púmice está desvitrificada com a formação de esferulitos.

Uma outra feição interessante diz respeito a concentrações de plagioclásio, minerais máficos e opacos, que na maioria dos casos apresentam formas arredondadas e foram classificados como nódulos. Esses nódulos podem ocorrer como:

a) cristal de biotita parcialmente reabsorvido com manteamento de plagioclásio ou com seus espaços vazios preenchidos por plagioclásio, piroxênio e opacos;

b) cristal esquelético de plagioclásio com seus espaços vazios preenchidos por biotita e/ou piroxênio, além de finas ripas de ilmenita (Foto 16);

c) plagioclásio e biotita esqueléticos, aparentemente intercrescidos, rodeados por cristais subédricos de plagioclásio que se arranjam radialmente em torno do núcleo (junto a algumas ripas de ilmenita), apresentando uma fina borda de plagioclásio e microfenocristais euédricos de hornblenda e ortopiroxênio nas porções mais externas (Foto 17);

d) glomérulo de fenocristais de plagioclásio parcialmente reabsorvidos intercrescidos com piroxênio (ferrossilita) e finas ripas de ilmenita (Fotos 28 e 29);

e) glomérulos de pequenos grãos de plagioclásio e ortopiroxênio idio a subédricos com bordas arredondadas. 


\subsubsection{Fragmentos vítreos (glass-shards)}

Seções delgadas de amostras afetadas por soldamento incipiente e alteração fase-vapor revelaram alguns poucos fragmentos vítreos (glass-shards) com textura de desvitrificação do tipo micropoiquilítica e/ou esferulitos axiolíticos, o que permitiu o seu reconhecimento em meio a matriz alterada.

Em rochas afetadas por maior soldamento, os glass-shards também puderam ser reconhecidos devido à desvitrificação sobreposta, porém os mesmos estão deformados, o que confere à matriz uma textura do tipo eutaxítica (Foto 18). Na amostra Pul-41, também afetada por forte soldamento, identificam-se texturas de reomorfismo, com púmices em sigmóides (Foto 19) e cristais rotacionados (Foto 20). Em amostras muito alteradas, a textura eutaxítica está obscurecida devido à serecitização que afeta a matriz.

Estruturas perlíticas (ver perlito no glossário), associada à formação de alguns esferulitos esféricos (Foto 21), apenas puderam ser observadas em amostras retiradas do ponto mais alto do cerro. Essas amostras não apenas apresentam-se menos alteradas como também foram pouco afetadas por alteração fase-vapor e soldamento (o que provavelmente contribuiu para a melhor preservação dessa textura).

\subsection{Descrição e composição química dos minerais}

\subsubsection{Plagioclásio}

É o mineral predominante nas rochas do $\mathrm{C}^{\circ}$ Pululus. Ocorre como cristaloclastos fragmentados ou fraturados dispersos pela matriz (40-48\%) e como fenocristais nos púmices (47-61\%), em ambos os casos apresentando teores de anortita entre 45 e $87 \%$.

A maioria dos fenocristais, assim como os cristaloclastos, foi pouco afetada por alteração; porém, quando presente, ela afeta principalmente os cristais pertencentes ao púmice, produzindo sericitização.

Os fenocristais com tamanhos menores que $2 \mathrm{~mm}$ são tabulares, euédricos a subédricos e exibem geminação de Albita. A superfície externa do cristal pode estar arredondada ou angulosa, lisa ou corroída. É comum o sobrecrescimento tardio de bordas limpas, claras e irregulares, com composição mais pobre em anortita. Também são comuns os cristais de plagioclásio intercrescidos às placas de biotita, orientados 

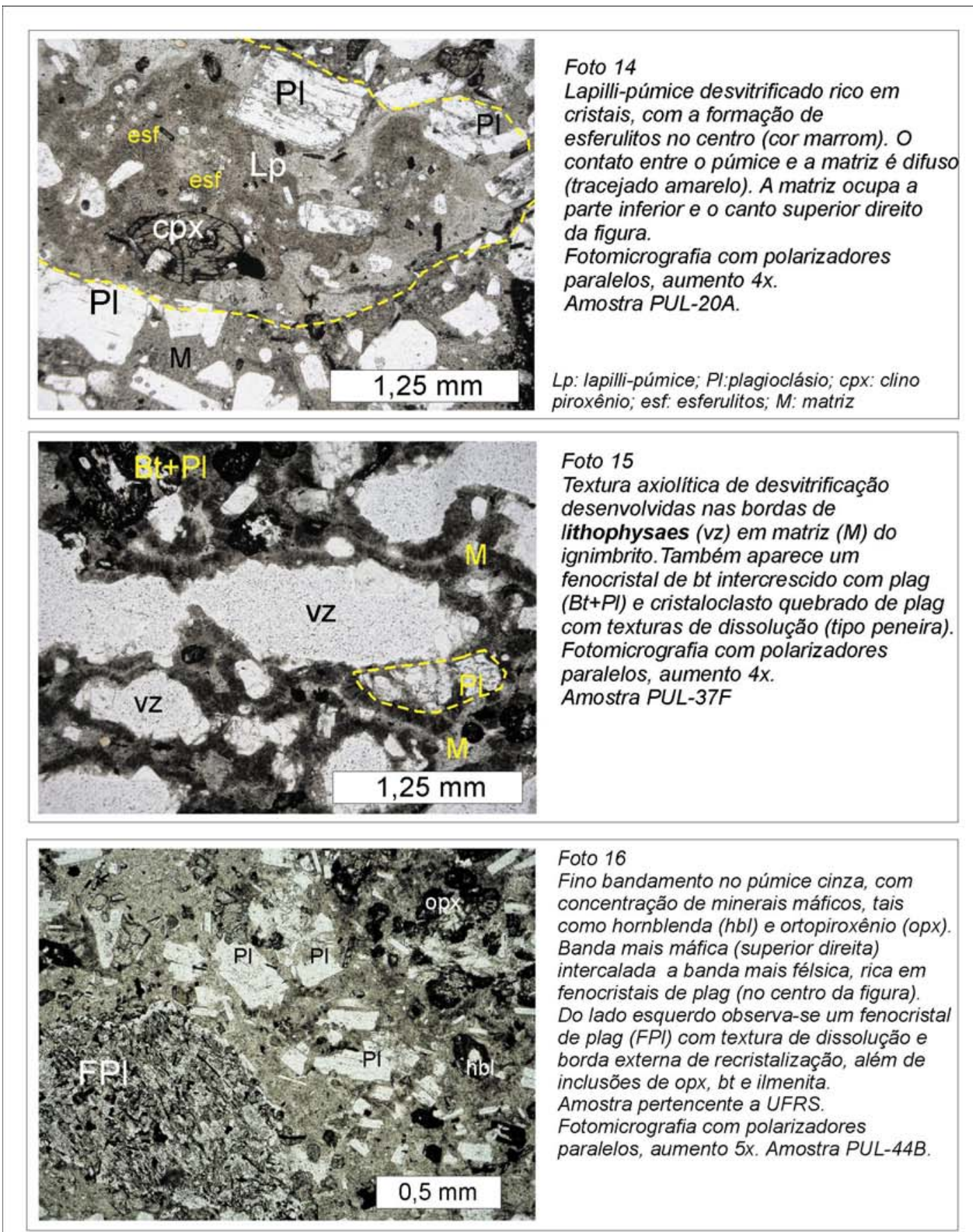

\section{Foto 16}

Fino bandamento no púmice cinza, com concentração de minerais máficos, tais como hornblenda (hbl) e ortopiroxênio (opx). Banda mais máfica (superior direita) intercalada a banda mais félsica, rica em fenocristais de plag (no centro da figura). Do lado esquerdo observa-se um fenocristal de plag (FPl) com textura de dissolução e borda externa de recristalização, além de inclusões de opx, bt e ilmenita.

Amostra pertencente a UFRS.

Fotomicrografia com polarizadores paralelos, aumento 5x. Amostra PUL-44B.

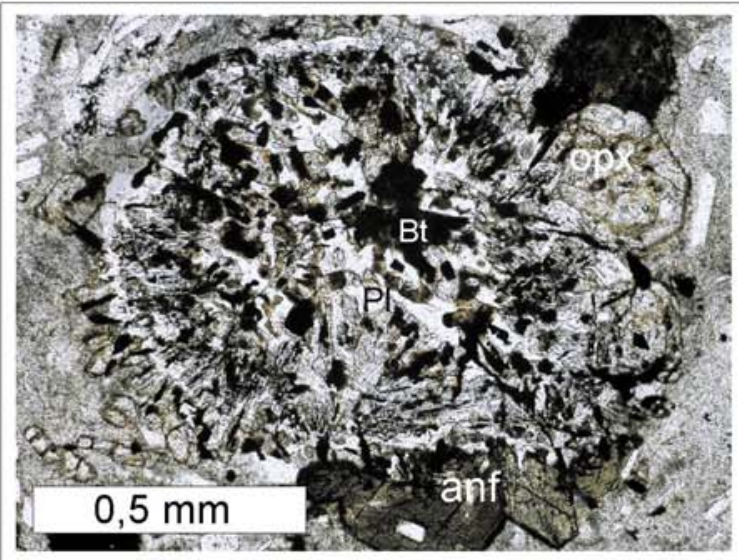

\section{Foto 17}

Nódulos de arranjo radial do plagioclásio, opacos e minerais máficos em torno de cristal esquelético de biotita (Bt) e plagioclásio (PI). Notar crescimento de cristais euédricos e sub-édricos de ortopiroxênio (opx) e hornblenda (anf) na borda do nódulo. Fotomicrografia com polarizadores paralelos, aumento 10x. Amostra PUL-44B. 


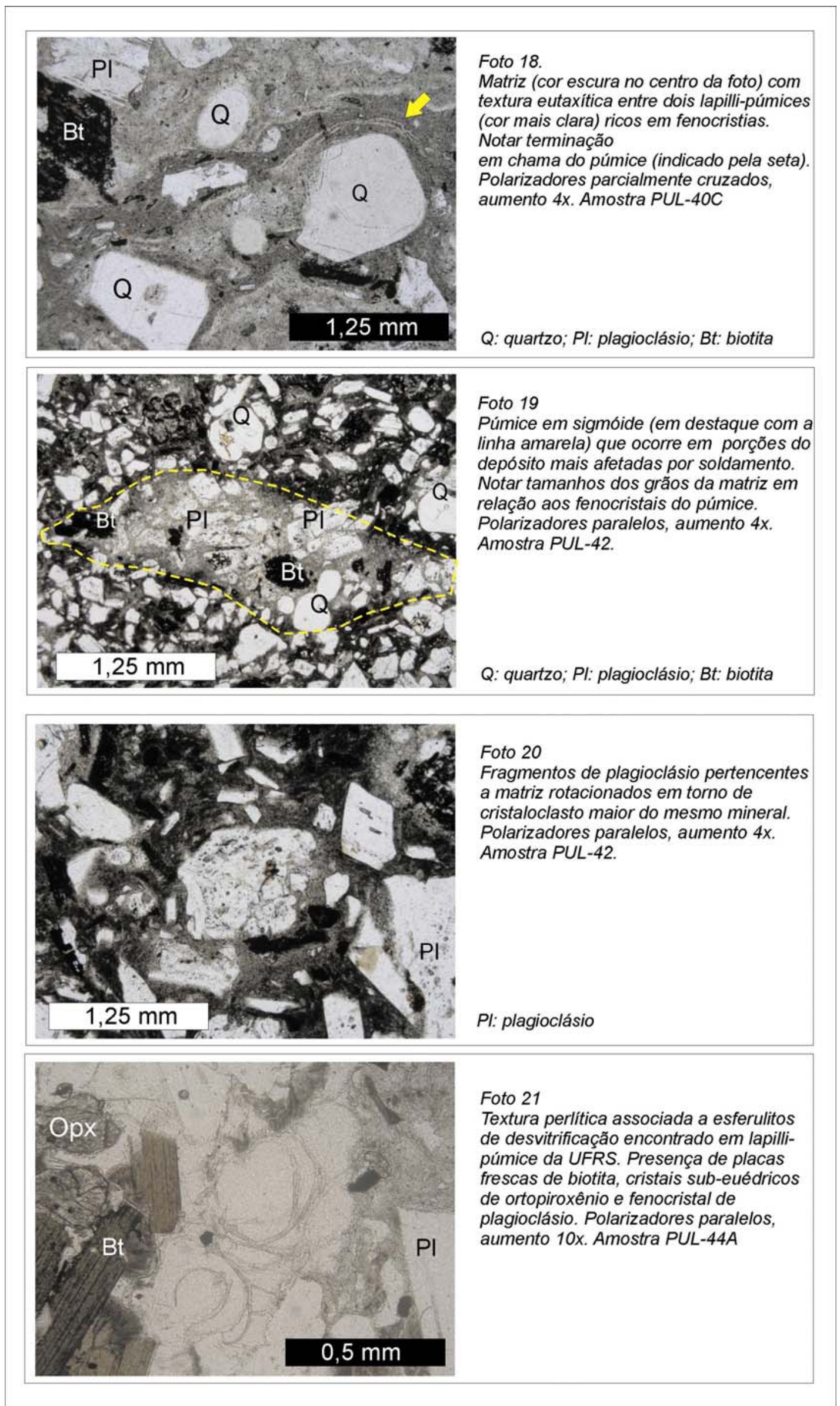


segundo os planos perpendiculares a 001 do mineral, ou contendo inclusões de ortopiroxênio, biotita, óxidos e, mais raramente, quartzo.

Os zoneamentos presentes são do tipo normal, inverso, oscilatório ou irregular complexo (Foto 22) e podem estar, ou não, associados a feições de dissolução, classificadas como: empoeirada (dusty texture) e em peneira (sieve-like texture; Foto 23). Estas texturas, quando presentes, se encontram preferencialmente no centro do cristal ou acompanhando alguma zona de crescimento. Também são observadas concentrações de inclusões fluidas ou minerais (quartzo, ortopiroxênio e óxidos) arranjados zonalmente ou dispersos nos grãos (Foto 24). O plagioclásio pertencente ao CIP (amostra $\mathrm{H}-03$ ) raramente está zonado, e, nos casos em que se observa zoneamento, este se resume apenas ao centro, a uma zona intermediária e uma fina borda, que freqüentemente apresenta sinais de instabilidade (com a borda levemente corroída).

A maioria dos cristais euédricos com zonas de crescimento normal não apresenta texturas de dissolução ou outras feições que evidenciem desequilíbrio na fusão, exceto pelas bordas levemente arredondadas. Seu zoneamento regular é muitas vezes quase imperceptível e as variações no conteúdo de An são muito pequenas, variando em geral de oligoclásio a labradorita.

Freqüentemente nos púmices também ocorrem grandes fragmentos angulares de plagioclásio com seu núcleo e zonas intensamente afetados por processos de dissolução ou com formas esqueléticas devido a reabsorção parcial. Seu zoneamento, abruptamente truncado, com bordas corroídas, engolfadas ou arredondadas e por vezes com um sobrecrescimento posterior de plagioclásio, indica cristais originais bem maiores que os atuais.

Análises de química mineral, obtidas mediante microssonda eletrônica, foram realizadas em fenocristais identificados no púmice com o objetivo de detectar variações composicionais nas zonas de crescimento e nas texturas de desequilíbrio (Tabela 1 do Anexo V). No geral, o conteúdo de An do plagioclásio varia de 43 a 86\% no ignimbrito e de 34 a $74 \%$ no CIP (Figura 14). As concentrações de $\mathrm{MgO}$ e $\mathrm{Fe}_{2} \mathrm{O}_{3}$ não mostram variações significativas do centro as bordas dos fenocristais e as concentrações de $\mathrm{K}_{2} \mathrm{O}$ variam entre 0,08 e 0,65 wt\% no ignimbrito e 0,17 e 0,64 wt\% na rocha intrusiva.

Com relação às variações de An do centro para a borda, os plagioclásios das unidades UFRI e UFC apresentam zoneamento oscilatório tendendo ao normal e variando entre bytownita-labradorita na UFRI $\left(\mathrm{An}_{64-85}\right.$ nos centros, $A n_{53-87}$ nas zonas e 
$A n_{51-73}$ nas bordas) e de andesina-bytownita na UFC ( $A n_{49-83}$ nos centros, $A n_{45-70}$ nas zonas e $\mathrm{An}_{49-57}$ nas bordas). A unidade UFRS, por outro lado, apresenta um zoneamento predominantemente inverso, com teores de An que oscilam entre An48 (andesina) e An85 (bytownita) para centro e borda, sem grandes oscilações num mesmo cristal.

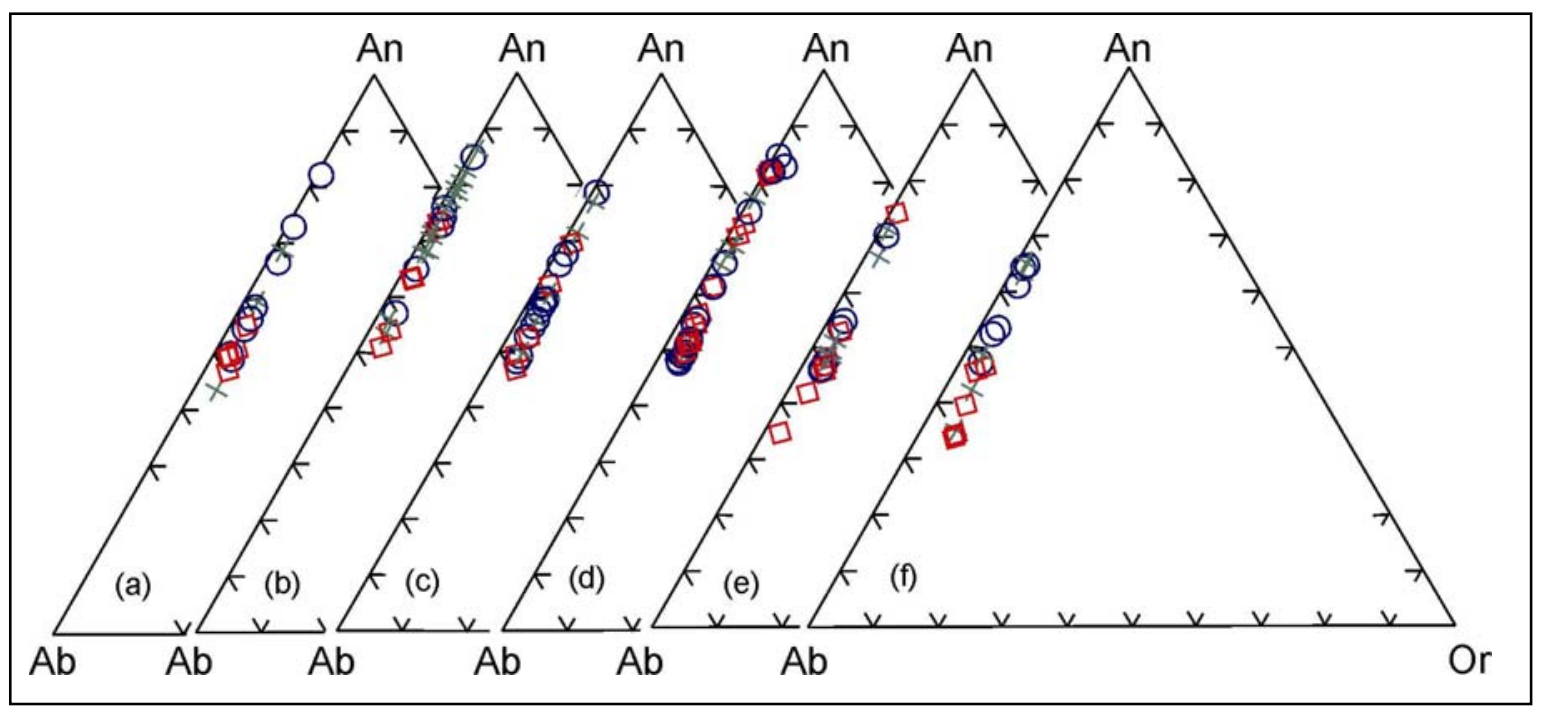

Figura 14. Diagramas ternários An-Ab-Or para classificação dos feldspatos. Para todos os diagramas: círculo azul = centro do cristal, cruz verde = zonas intermediárias e losango vermelho = borda. (a)UFC; (b)UFRI; (c)UFRS - púmice branco; (d) UFRS - púmice cinza; (e)CIP; (f) FLP.

As análises químicas também demonstraram que as texturas de dissolução ocorrem, em geral, em zonas mais cálcicas que antecedem a uma queda de teor em An na próxima zona. As análises dos espaços originalmente vazios, gerados pela dissolução do plagioclásio, mostra que estão agora preenchidos por material vítreo e albita. Na Figura 15 foram projetados os valores de anortita versus ortoclásio ${ }^{1}$ a fim de elucidar as variações composicionais de centro a borda de alguns cristais selecionados.

\footnotetext{
${ }^{1}$ Optou-se utilizar os valores de ortoclásio em vez de albita devido à sua maior distribuição segundo o "eixo y" do diagrama, permitindo, de tal forma, uma maior facilidade para visualizar as variações de anortita no cristal.
} 


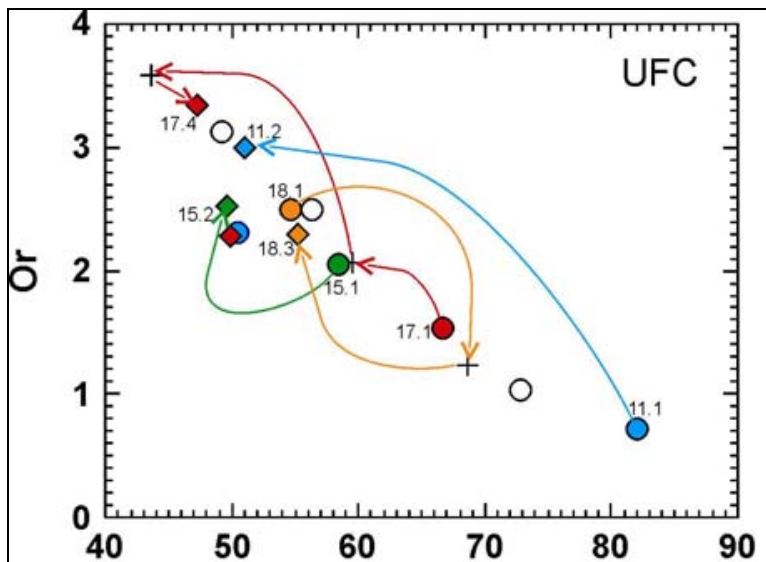

11. cristal idiomórfico com borda albítica.

11.1 centro;

11.2 borda.

15. Fragm. de fenocristal incluso em qtz poiquilítico. Com textura em peneira e zoneamento complexo 15.1 centro (textura em peneira);

15.2 borda limpa.

17. Microfenocristal idiomórfico zonado.

17.1 centro com textura em peneira;

17.2 zona;

17.3 borda;

17.4 borda posterior.

18. Fragmento de grande fenocristal zonado e limpo. 18.1 centro;

18.2 zona;

18.3 borda.

An

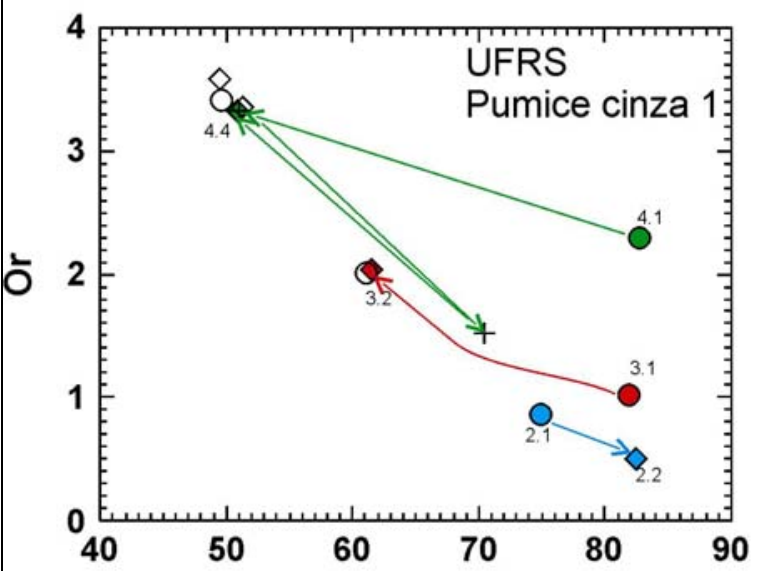

2. Cristal fraturado com textura em peneira no núcleo. Borda limpa.

2.1 centro;

2.2 borda.

3. Fenocristal com textura em peneira bem avançada no centro.

3.1 centro;

3.2 borda.

4. Cristal com centro empoeirado e zoneamento um pouco irregular.

4.1 centro com textura empoeirada e sericitizada;

4.2 zona;

4.3 zona;

4.4 borda;

An

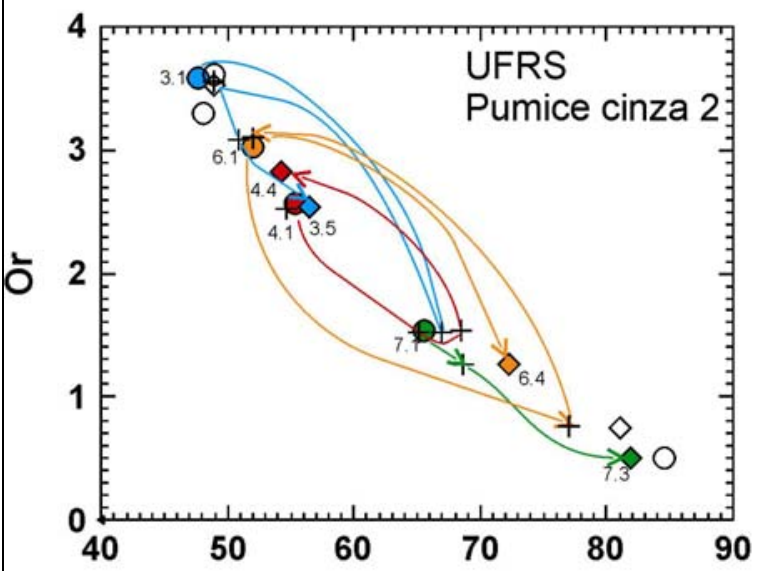

3. Fenocristal de palgioclásio zonado.

3.1 centro;

3.2 a 3.4 zona;

3.5 borda.

4. Cristal zonado, com núcleo limpo e textura em peneira associado ao zoneamento.

4.1 centro limpo;

4.2 zona com textura em peneira;

4.3 zona irregular e limpa, com textura de dissolução; 4.4 borda.

6. Cristal zonado com textura tipo peneira no núcleo e borda limpa.

6.1 centro (área limpa);

6.2 centro (área com textura em peneira);

6.3 zona limpa;

6.4 borda limpa.

7. Pequeno cristal com marcante zoneamento. Núcleo

com textura em peneira.

7.1 centro;

7.2 zona;

An

7.3 borda

Figura 15. Diagramas de variação anortita $\mathrm{x}$ ortoclásio para plagioclásios pertencentes às diferentes unidades do $\mathrm{C}^{\circ}$ Pululus. Os melhores exemplos foram selecionados e numerados (sentido centroborda), utilizando cores distintas para cada análise (símbolos cheios e setas coloridas). As respectivas descrições estão listadas ao lado. Para identificar as variações que ocorrem do centro para a borda nos diferentes cristais, deve-se acompanhar as setas com as cores correspondentes. 


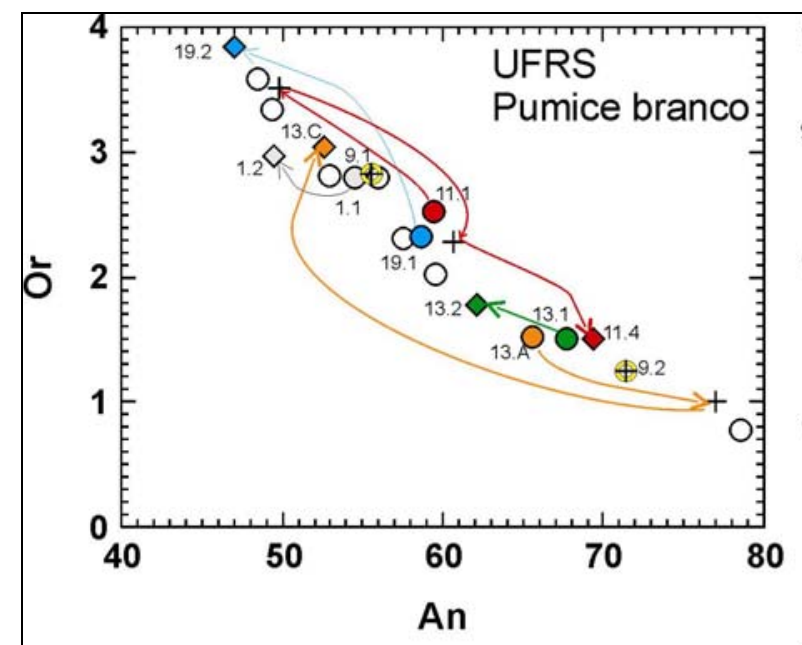

1. Cristal zonado com textura empoeirada na borda. 1.1 centro;

1.2 borda.

9. Fragmento de grande fenocristal, com feiçöes de dissolução bem desenvolvidas.

9.1 área limpa (resquicio);

9.2 área com feições de dissolução (resquício),

11. Fenocristal com discreto zoneamento oscilatóriol inverso e aparente zoneamento complexo no centro. 11.1 centro;

11.2 a 11.3 zona limpa;

11.4 borda.

13. Cristal idiomórfico limpo e sem zoneamento com fragm de fenocristal (13A-C) pegado em sua borda.

13.1 centro

13.2 borda;

13. A centro

13. B zona;

13. C borda.

19. Grande fenocristal limpo e sem zoneamento.

19.1 centro;

19.2 borda.

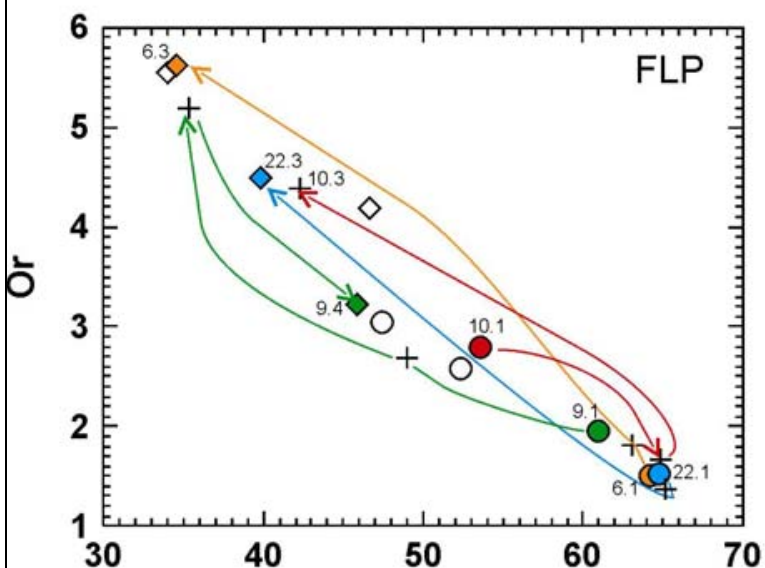

6. Cristal zonado sub-idiomórfico com bordas reabsorvidas e inclusäo de óxido avermelhado no centro.

6.1 centro;

6.2 zona;

6.3 borda.

9. Cristal subidiomórfico zonado com núcleo empoeirado.

9.1 centro:

9.2 a 9.4 zonas;

9.5 borda.

10. Cristal idiomórfico zonado.

10.1 centro;

10.2 zona com textura empoeirada;

10.3 borda limpa.

22. Cristal idiomórfico zonado.

22.1 centro;

22.2 zona;

22.3 borda.

An

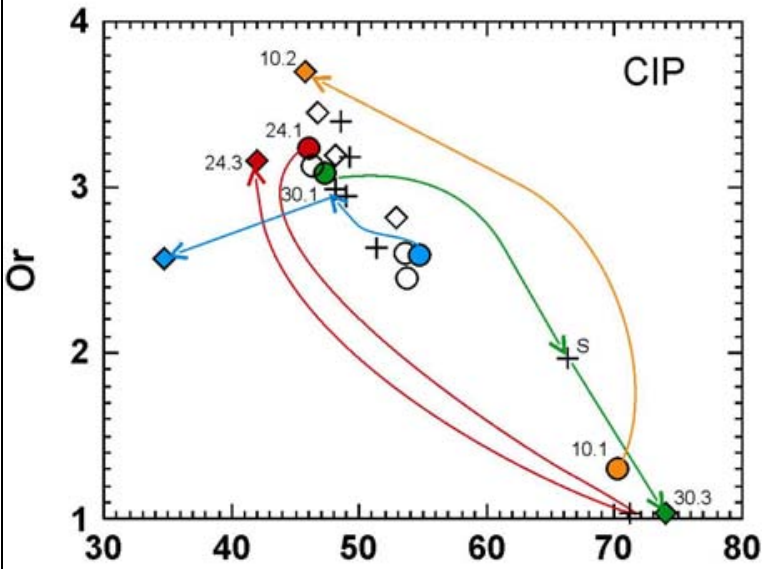

An

10. Fenocristal zonado, limpo (sem texturas).

10.1 centro;

10.2 borda.

11. Microcristal idiomórfico com zoneamento complexo no núcleo, zona com textura em peneira e fina borda levemente corroída.

11.1centro:

11.2 zona;

11.3 borda

24. Pequeno fenocristal idiomórfico zonado, com textura em peneira.

24.1 centro limpo:

24.2 zona com textura em peneira;

24.3 borda limpa levemente corroída.

30. Pequeno cristal sub-idiomórfico zonado. 30.1 centro limpo;

30.2 zona com textura em peneira;

30.3 borda fina, limpa e corroida.

centro

intermed. borda

Figura 15 (continuação) - Diagramas de variação anortita x ortoclásio para plagioclásios pertencentes as diferentes unidades do $\mathrm{C}^{\circ}$ Pululus. Os melhores exemplos foram selecionados e numerados (sentido núcleo-borda). As respectivas descrições estão listadas ao lado. 


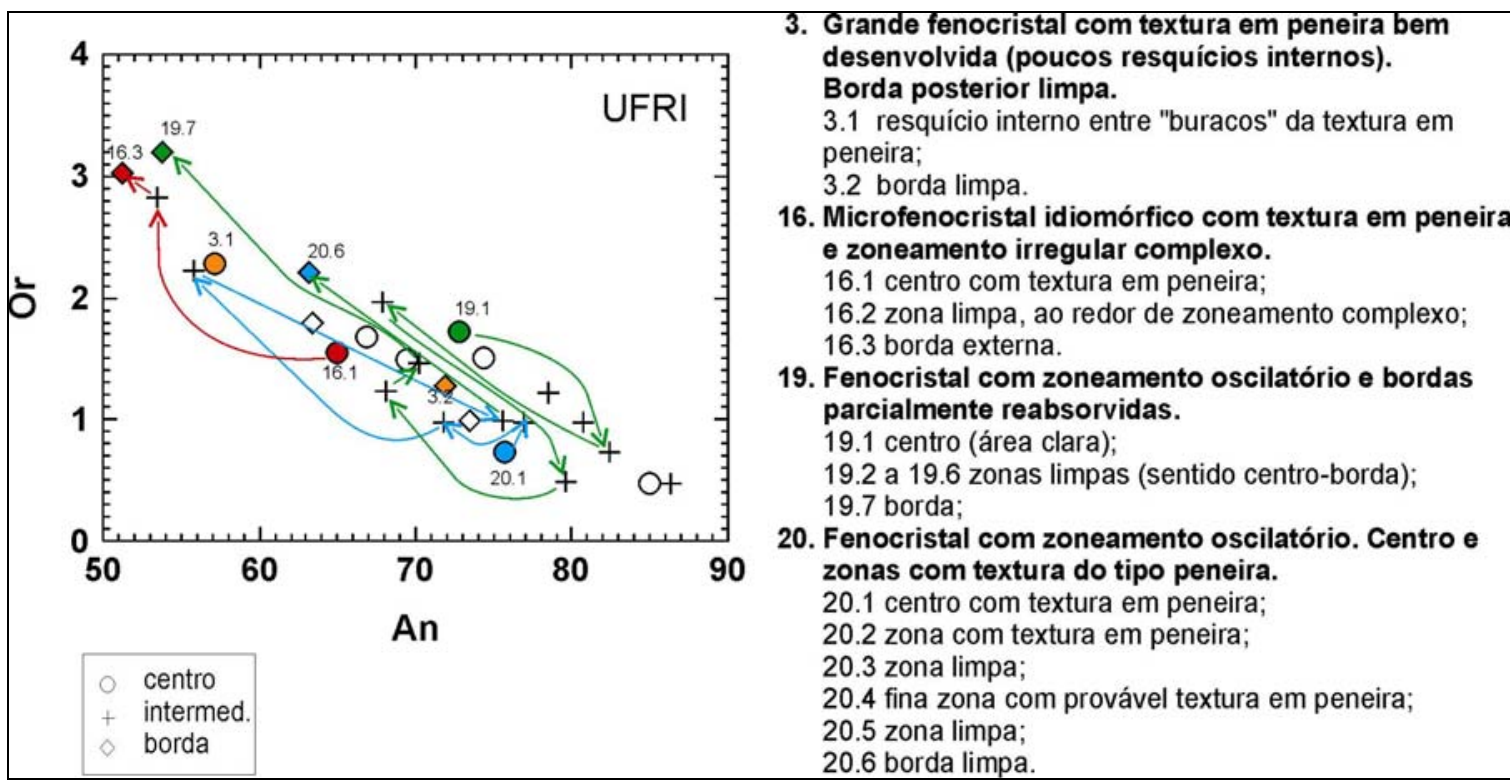

Figura 15 (continuação) - Diagramas de variação anortita x ortoclásio para plagioclásios pertencentes às diferentes unidades do $\mathrm{C}^{\circ}$ Pululus. Os melhores exemplos foram selecionados e numerados (sentido núcleo-borda). As respectivas descrições estão listadas ao lado.

\subsubsection{Biotita}

É o mineral máfico mais abundante nas rochas do $\mathrm{C}^{\circ}$ Pululus. Ocorre dispersa pela matriz na forma de cristaloclastos (25-30\%) ou como fenocristais nos púmices (17-28\%).

Seus cristais são inequigranulares (variando de fenocristais a cristais esqueléticos), em forma de palhetas euédricas a subédricas, bordas fragmentadas e/ou corroídas e com pleocroísmo verde-amarelado e vermelho. A grande maioria apresenta-se quebrada e/ou deformada (com a clivagem dobrada) e orienta-se paralelamente à direção de compactação e soldamento que afetou a rocha, podendo moldar-se ao redor de outros fenocristais ou de pequenos púmices.

É comum estar intercrescida com plagioclásio ou apresentar inclusões de plagioclásio, ortopiroxênio e opacos; podendo, além do mais, formar aglomerados junto a estes. Também é freqüente encontrá-la manteada pelo quartzo e, principalmente, pelo feldspato (Foto 25).

Seu grau de alteração varia em todo depósito. Nas unidades mais afetadas por alteração fase-vapor e soldamento (UFRI e UFC), a biotita apresenta espessas bordas de oxidação e muitas vezes está substituída parcialmente ou completamente por opacos (ocorrendo como pseudomorfos). As amostras que contêm os cristais mais 
frescos de biotita foram retiradas do cume do cerro (UFRS), onde a alteração fasevapor e o soldamento estiveram praticamente ausentes (Foto 21).

Ao microscópio foram diferenciados quatro grupos distintos de biotita: 1 . pequenas e finas placas verdes; 2. fenocristais, verdes e vermelhos, com intercrescimento de plagioclásio segundo planos normais a 001 da biotita, com bordas oxidadas e núcleo ainda preservado; 3 . minúsculas plaquetas completamente oxidadas associadas, geralmente, a glomérulos de plagioclásio; 4. fenocristais castanhos e vermelhos de tonalidade escura com inclusões de opacos, ortopiroxênio e plagioclásio, e bordas lisas irregulares ou engolfadas.

Contudo, o que fica evidente é que a composição desse mineral praticamente não se altera, independentemente do seu modo de ocorrência (Tabela 2 do Anexo V). Todas as biotitas apresentam valores de $\mathrm{mg \#}\left(\mathrm{Mg} / \mathrm{Fe}^{2}+\mathrm{Mg}\right)$ dentro do intervalo 0,44 0,67, com conteúdo de Ti entre 0,489 - 0,756 a.p.f.u. (átomos por fórmula unitária). Excepcionalmente, algumas discretas variações na composição da biotita puderam ser identificadas, como é o caso de cristais intercrescidos, manteados ou com inclusões de plagioclásio que apresentam concentrações mais baixas em Ba (aprox. 0,006 a.p.f.u.) que as placas isoladas.

Com relação às unidades ignimbritícas, as biotitas da amostra PUL-20a (UCI) também se diferenciam das demais amostras por apresentarem alto $\mathrm{Al}_{2} \mathrm{O}_{3}, \mathrm{CaO}, \mathrm{TiO}$ e $\mathrm{MgO}$ e baixo $\mathrm{FeO}, \mathrm{MnO}, \mathrm{Na}_{2} \mathrm{O}$ e $\mathrm{Cl}$.

\subsubsection{Quartzo}

Ocorre como cristais bipiramidais euédricos a subédricos, comumente com feições de reabsorção (com bordas embainhadas e engolfadas; Foto 26) ou completamente arredondadas em forma de gota (Fotos 18 e 19). Também é comum a presença de grandes fenocristais poiquilíticos que englobam pequenos aglomerados de plagioclásio e biotita (Foto 27). Podem ocorrer como pequenos fragmentos ou apresentar partes quebradas ou fraturas internas (permitindo o desenvolvimento de uma reabsorção do núcleo do cristal). Na matriz o quartzo representa de 16 a $24 \%$ da assembléia mineral, enquanto no púmice de 9 a $19 \%$.

\subsubsection{Piroxênio}

Seu principal modo de ocorrência é como fenocristais no púmice, estando praticamente ausente na matriz. O ortopiroxênio representa, em geral, $<5 \%$ da assembléia mineralógica, podendo ocorrer em até 10\% (como na amostra PUL-31 da 
UFRS). Já o clinopiroxênio raramente representa mais de $2 \%$ da mesma assembléia, com exceção do púmice PUL-24 (UFC), em que constitui $3 \%$ dos cristaloclastos da matriz e em torno de $4 \%$ dos fenocristais do púmice.

\subsubsection{Classificação e Nomenclatura}

A classificação e a nomenclatura dos piroxênios atualmente aceitas pela Associação Mineralógica Internacional (International Mineralogical Association - IMA) estabelecem uma seqüência adequada de diagramas para classificar os minerais a partir dos dados químicos, ao mesmo tempo em que eliminam muitos nomes de espécies antigamente usados na literatura, considerando-os obsoletos (MORIMOTO et al., 1989). No caso particular de séries de solução sólida completa, como a dos piroxênios ortorrômbicos, utilizam apenas os nomes dos membros finais (enstatita e ferrossilita), estabelecendo a divisão em $\mathrm{En}_{50} \mathrm{Fs}_{50}$ e eliminando, conseqüentemente, a antiga nomenclatura de Poldervaart (1947 in: DEER, HOWIE e ZUSSMAN, 1978). Neste trabalho será utilizada a nomenclatura proposta pelo IMA, tomando também em consideração os aspectos texturais do mineral nas rochas e fazendo menção, entre parênteses, aos nomes antigos das respectivas espécies minerais.

\subsubsection{Os piroxênios das rochas do Cerro Pululus}

O ortopiroxênio mais abundante, denominado de ferrossilita, apresenta valores médios de $\mathrm{En}_{52} \mathrm{Wo}_{2,5} \mathrm{Fs}_{46,5}$ e pode variar entre $\mathrm{En}_{59} \mathrm{Wo}_{2} \mathrm{Fs}_{39.5}$ (hiperstênio) e $\mathrm{En}_{44} \mathrm{Wo}_{2} \mathrm{Fs}_{54}$ (ferro-hiperstênio), com valor de mg\# entre 0,45 e 0,59 (Figura 16; Tabela 3 do Anexo V). Esse ortopiroxênio ocorre como prismas inequigranulares (<0,5 mm), euédricos a subédricos (Foto 17), com freqüentes fraturas internas, bordas quebradas, além de finas a grossas bordas de oxidação. Os cristais podem ser ricos em inclusões de opacos; ou ocorrer como prismas individuais associados a concentrações de minerais máficos (biotita, hornblenda e, predominantemente, ortopiroxênio) nos púmices cinzas. Quando forma cristais zonados, a ferrossilita aparece bordejando um segundo tipo de ortopiroxênio, a enstatita, com contatos difusos, podendo, além do mais estar intercrescido ao plagioclásio (Fotos 28 e 29).

A enstatita, que varia entre $\mathrm{En}_{76} \mathrm{Wo}_{2} \mathrm{Fs}_{22}$ e $\mathrm{En}_{67} \mathrm{Wo}_{2} \mathrm{Fs}_{31}$ (bronzita), exibe valores de mg\# entre 0,70 e 0,77 e pode ocorrer como pequenos cristais subidiomórficos a xenomórficos isolados apresentando suas bordas corroídas e arredondadas, com inclusões de opacos e plagioclásio, como núcleo de cristais zonados (com borda de ferrossilita). A enstatita não foi encontrada no FLP e tampouco nos púmices branco da UFC e UFRS (Tabela 3 do Anexo V e Figura 16 b, c, d, f). 


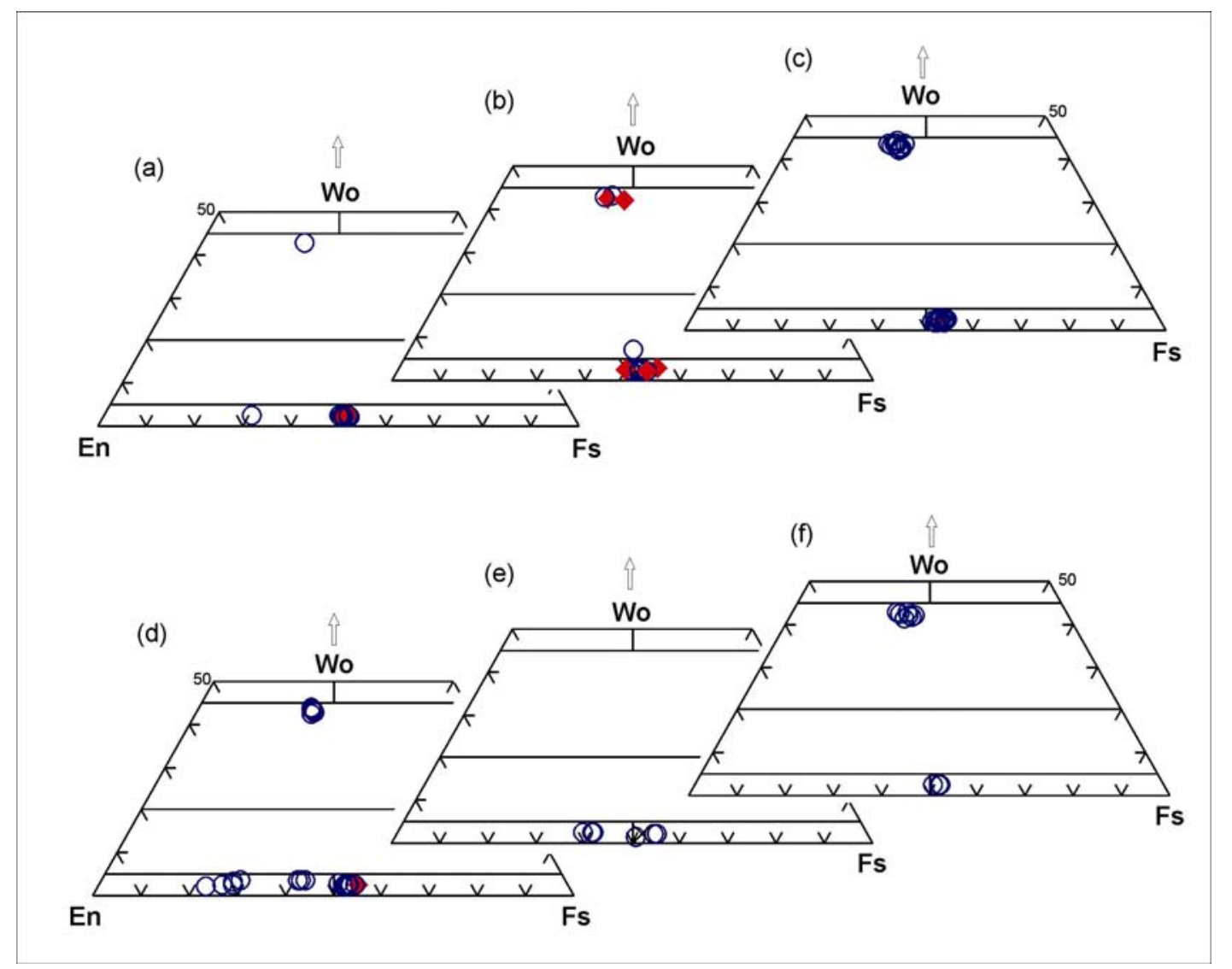

Figura 16. Diagramas Wo-En-Fs para classificação dos piroxênios de Morimoto et al. (1989). Para todos os diagramas: círculos vazios em azul = centro e losangos cheios em vermelho = borda. (a) UFRI; (b) UFC; (c) UFRS - púmice branco; (d) UFRS - púmice cinza; (e)CIP; (f) FLP.

Já o clinopiroxênio está representado pela augita com valores de mg\# entre 0,54 e 0,64 . Ocorre em todas as unidades e se apresenta como cristais inequigranulares $(<0,5 \mathrm{~mm})$, euédricos a subédricos, com bordas irregulares, quebradas e com finas a grossas bordas de oxidação, podendo, além disso, conter inclusões de plagioclásio e ortopiroxênio (ferrossilita).

Apenas um cristal de pigeonita foi reconhecido e corresponde a um pequeno prisma euédrico, encontrado no púmice PUL-20a, da unidade intermediária (Figura 16b).

\subsubsection{Anfibólio}

É um mineral raro nas rochas de Pululus e quando presente não representa mais de $1 \%$ da assembléia. Ocorre nos púmices da UFC e nos púmices cinza da UFRS, sendo que nesta última pode ser encontrado nas concentrações máficas (que constituem e caracterizam o bandamento do púmice) ou nas bordas dos nódulos, como descrito no item 7.1 (Fotos 16 e 17). 
Na unidade UFC o anfibólio ocorre parcialmente ou completamente alterado, apresentando, no primeiro caso, grossas bordas de alteração e oxidação, com seu núcleo de coloração castanho-avermelhado ainda preservado, e no segundo, uma completa substituição do anfibólio (pseudomorfo) por um fino agregado de plagioclásio, piroxênio e óxidos.

Nas amostras de púmice da UFRS, o anfibólio ocorre como minúsculos cristais eqüigranulares, euédricos, de cores verde e marrom e com finas bordas de oxidação. Composicionalmente, classificam-se como magnésio-hornblenda e tschermakita-hornblenda (Figura 17), com valores de mg\# entre 0,55 e 0,66 e AllV entre 1,36 e 1,53 a.p.f.u.

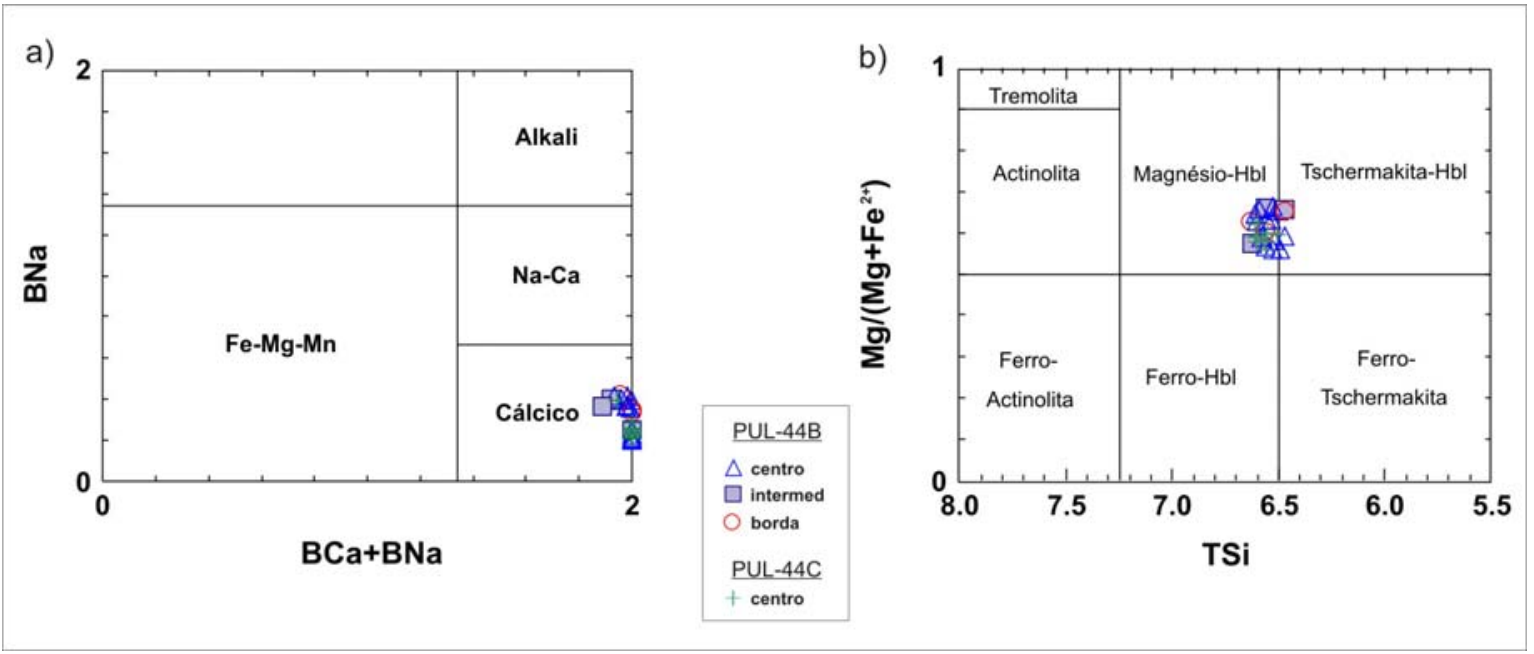

Figura 17.Diagramas de classificação para hornblendas. a) classificação geral de hornblenda nos quatro grupos principais, b) classificação para hornblendas cálcicas $\left[(\mathrm{Na}+\mathrm{K})_{A}<0,5\right]$, segundo Leake et al. (1997).

\subsection{6 Óxidos}

Resultantes da alteração de minerais máficos ou associados aos pequenos nódulos e aos glomérulos de ortopiroxênio e plagioclásio, raramente ocorrem como minerais isolados. Poucos fenocristais euédricos de magnetita foram encontrados dispersos no púmice. Pequenos cristais de ilmenita foram observados principalmente associados aos glomérulos de ortopiroxênio, plagioclásio e biotita. Nenhuma evidência de equilíbrio entre estes dois óxidos foi encontrada para possíveis estudos de $\mathrm{T}_{\text {e }} \mathrm{fO}_{2}$. 


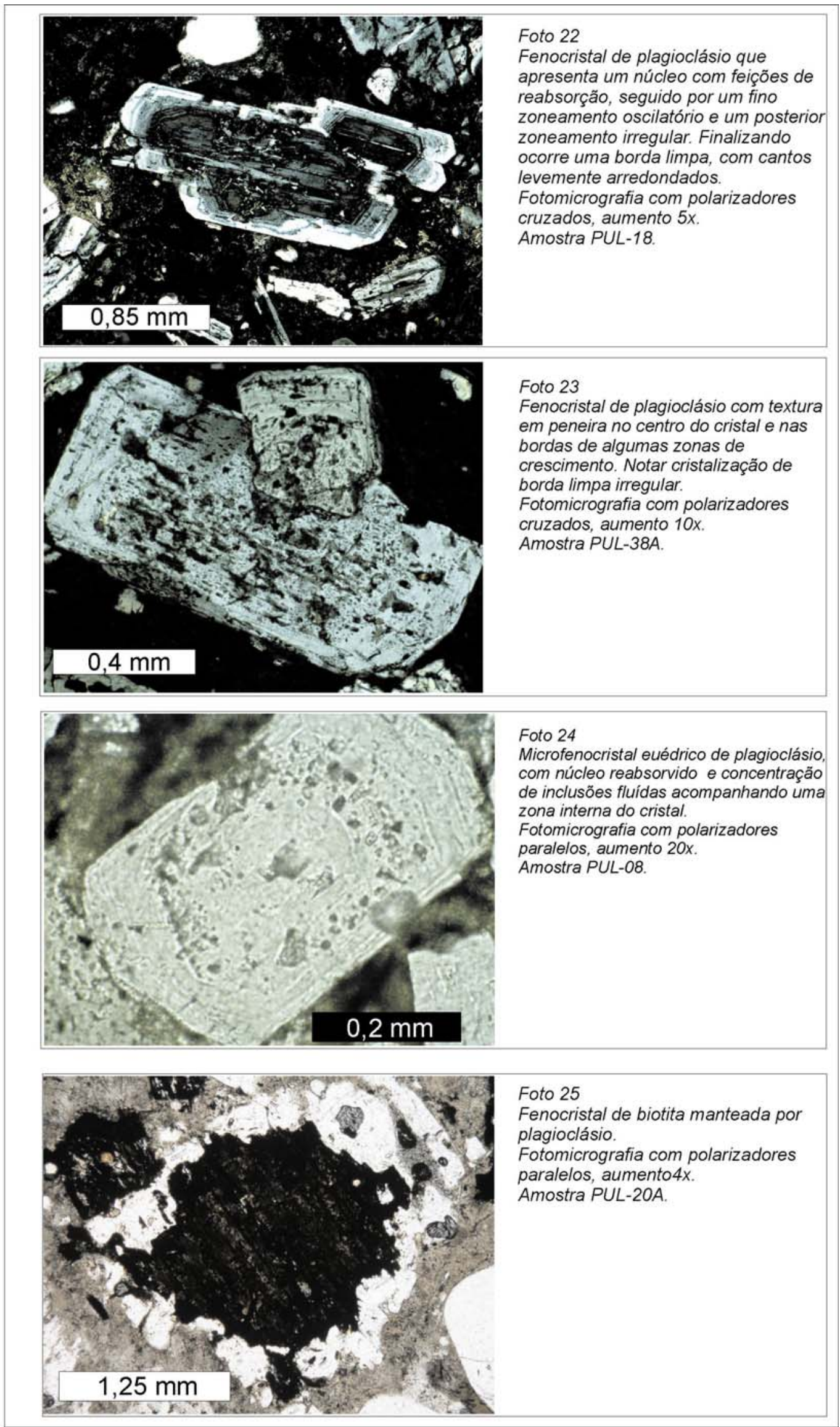




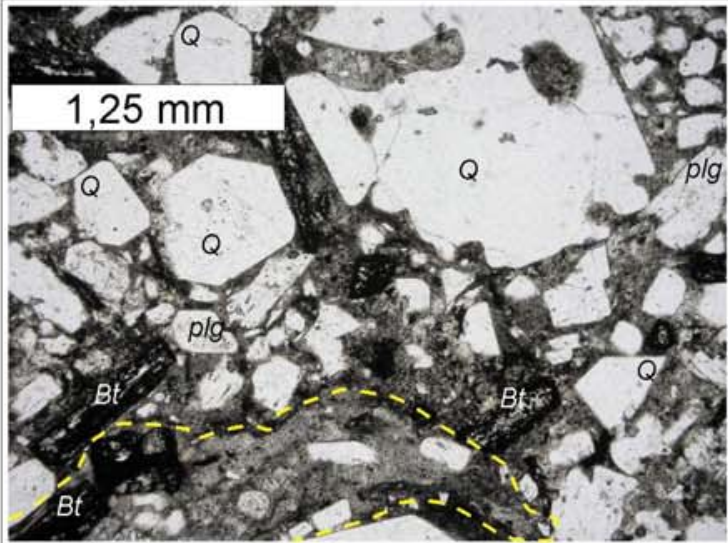

Foto 26

Fotomicrografia de porção da matriz contendo grande cristaloclasto de quartzo com golfos de reabsorção, além de outros cristais menores com bordas arredondadas ou fragmentadas. $\mathrm{Na}$ parte inferior da fotografia observa-se um púmice com bordas difusas e tipo "chama" (em destaque com linha amarela). Notar cristais de biotita completamente oxidados.

Fotomicrografia com polarizadores paralelos, aumento $4 \mathrm{x}$.

Amostra: PUL-32

Q: quartzo; Bt: biotita, plg: plagioclásio

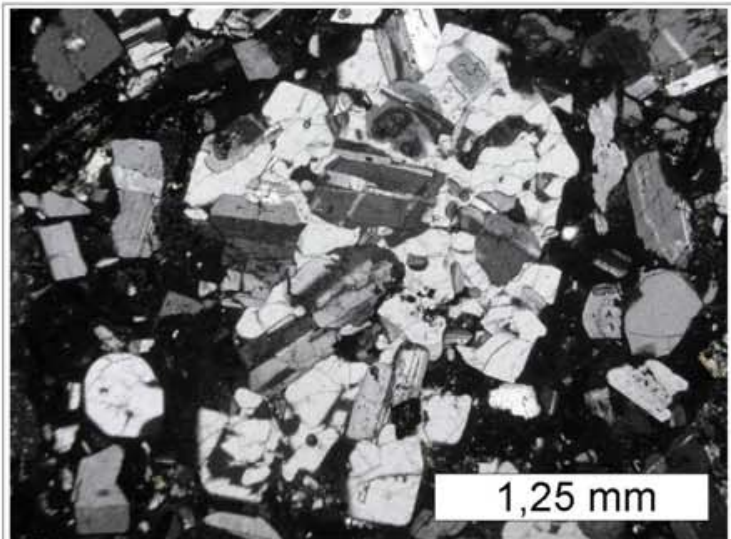

\section{Foto 27}

Quartzo poiquilitico anédrico

englobando microfenocristais de plagioclásio.

Fotomicrografia com polarizadores cruzados, aumento $4 x$.

Amostra: PUL-28A

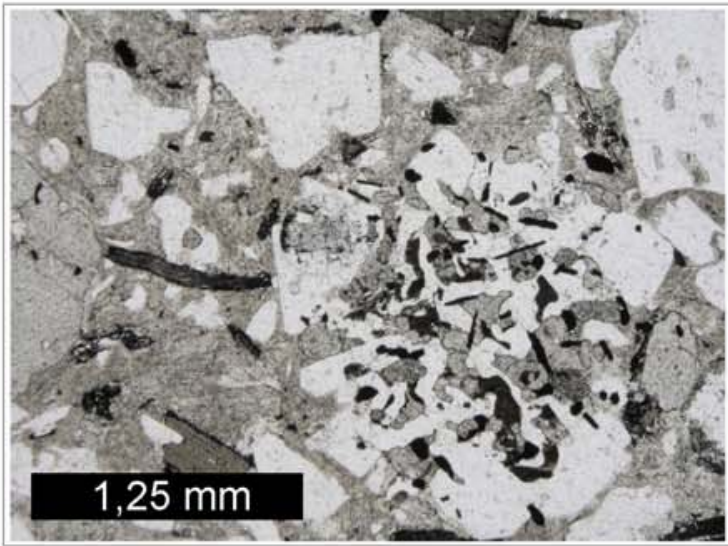

\section{Foto 28}

Intercrescimento de ortopiroxênio (hiperstênio) com cristais de plagioclásio Presença de opacos (ilmenita).

Fotomicrografia com nicóis paralelos, Fotomicrografia com polarizadores paralelos, aumento $4 x$.

Amostra: PUL-44D

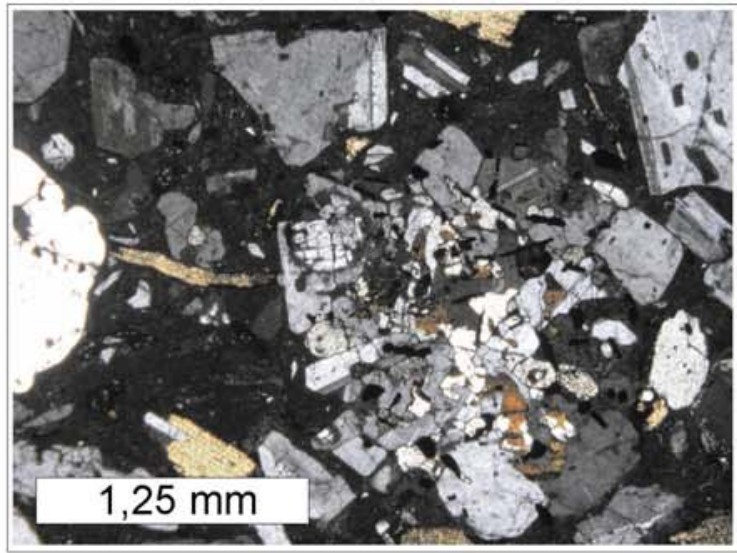

Foto 29

Idem ao anterior.

Polarizadores cruzados, aumento $4 x$. 


\section{Geoquímica}

Nos estudos geoquímicos de rochas vulcanoclásticas, é sempre prudente realizar as análises de púmices separados da matriz. Isso se deve ao fato de que esses fragmentos, além de apresentarem menor probabilidade de contaminação por xenocristais e/ou fragmentos líticos (como é o caso da matriz), são os únicos constituintes do depósito que dão mais segurança quanto a sua origem (fragmentos cognatos) e fornecem a composição geoquímica mais aproximada do magma em questão.

Além do mais, cristais previamente gerados no magma podem ser perdidos durante a erupção e o transporte do fluxo piroclástico e as variações resultantes na matriz podem distorcer ainda mais a composição geoquímica original (CAS \& WRIGHT, 1987; FREUNDT \& ROSI, 1998).

Os fragmentos líticos, por sua vez, podem ser de origens diversas, e a matriz do ignimbrito pode estar constituída não apenas por cinzas geradas durante a explosão, como também por poeira, cristais e outros fragmentos menores préexistentes, que foram facilmente recolhidos durante a passagem do fluxo (xenocristais e fragmentos líticos acidentais).

\subsection{Seleção de amostras}

Para a realização das análises geoquímicas, foram escolhidos quatro perfis representativos do $\mathrm{C}^{\circ}$ Pululus e deles foram separados um total de 12 lapilli-púmices (ver Tabela A).

Cada um desses púmices foi escolhido como representativo para a unidade considerada, respeitando-se uma ordem estratigráfica de base a topo do depósito (ver Tabela A, abaixo, e Figura 2 do anexo II). Os resultados obtidos encontram-se na tabela do Anexo VI.

Para efeito de comparação, também foram analisadas duas amostras de matriz (PUL-10M e PUL-44M), para certificar a variabilidade química entre púmice e rocha total. E quatro púmices para caracterizar as diferenças entre os três tipos de púmices encontrados no depósito:

- púmice rosa (PUL-24R) e púmice branco (PUL-24B) pertencentes à UFC (Perfil X); 
- púmice cinza (PUL-44PC) e púmice rosa (PUL-44PR) da UFRS (Ponto cume);

Outras amostras analisadas foram (análises de rocha total):

- PUL-38E - fragmento lítico plutônico (FLP) encontrado nos depósitos e de provável origem cognata;

- $\quad \mathrm{H}-03$ - amostra do corpo intrusivo (CIP), gentilmente cedida pelos geológos Fracchia, D. e Dr. Caffe, P.J., do Instituto de Geologia y Mineria (IdGyM; UNJu - Arg);

- M-194 - amostra de matriz do Ign. Vilama, pertencente ao topo da "Unidad de Esfriamiento Superior" (UESt) de Soler, 2005 e Soler et al., 2007, gentilmente cedida pelo pesquisador.

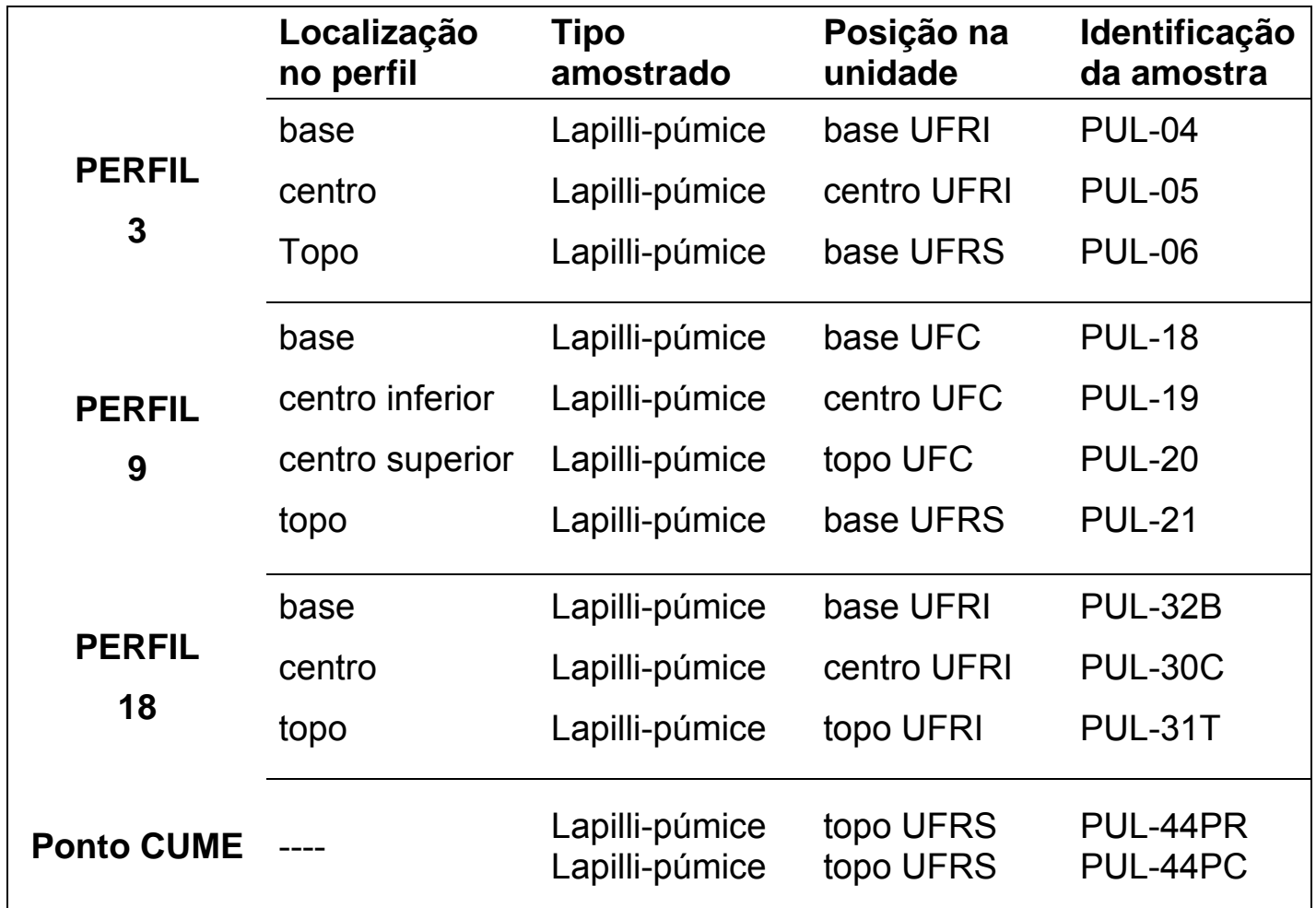

Tabela A. Listagem dos perfis e das amostras selecionadas para os estudos de geoquímica (ver figuras esquemáticas para cada perfil no Anexo II).

A amostra M-194 já havia sido analisada no Laboratório de Geoquímica do IdGyM-UNJu e publicada por Soler (2005), porém optou-se por refazer a análise no mesmo laboratório das demais amostras (Laboratório de Geoquímica do IGc-USP) para oferecer uma comparação dos dados mais precisa neste trabalho. Como 
resultado da comparação dos dados obtidos nos dois laboratórios notou-se que as diferenças entre os elementos maiores são pequenas, enquanto os traços apresentam variações mais contrastantes ${ }^{2}$, principalmente, quanto às concentrações de $T h, U$ e $Z r$.

Sendo assim, análises de elementos maiores realizadas pelo laboratório do IdGyM-UNJu e já apresentadas em trabalho anterior sobre o $\mathrm{C}^{\circ}$ Pululus $^{3}$ também foram incluídas nos diagramas de tipo Harker da Figura 19 e estão listadas na Tabela B. As análises de elementos traços não foram utilizadas.

\begin{tabular}{|lllll|}
\hline $\begin{array}{l}\text { Identificação } \\
\text { da amostra }\end{array}$ & Ponto & $\begin{array}{l}\text { Localização } \\
\text { no perfil }\end{array}$ & Tipo amostrado & $\begin{array}{l}\text { Posição na } \\
\text { unidade }\end{array}$ \\
\hline PUL-36 & P. 22 & ----- & Lapilli-púmice & topo UFRI \\
PUL-29 & P. 15 & ---- & Lapilli-púmice & topo UFRI \\
PUL-23 & PERFIL X & base & Lapilli-púmice & base UFC \\
PUL-15P & PERFIL X & Topo & Lapilli-púmice & topo UFC \\
\hline
\end{tabular}

Tabela B. Listagem de amostras selecionadas para os estudos de geoquímica

\subsection{Elementos maiores}

As rochas do $\mathrm{C}^{\circ}$ Pululus têm composição dacítica, com valores de $\mathrm{SiO}_{2}$ entre 63,56 e $65,74 \%$ (Figura 18a). Pertencem à série cálcio-alcalina rica em potássio e apresentam características meta a peraluminosas, com razões $A / C N K$ variando entre 0,90 e 1,04 e índices mg\# entre 26,77 e 41,65 (Figura 18b;c).

Os diagramas de tipo Harker para elementos maiores (Figura 19) apontam para uma homogeneidade química dentro do conjunto de amostras provindas do cerro. No entanto, ao analisar individualmente cada unidade de fluxo observa-se a existência de uma pequena diferenciação em cada uma delas.

\footnotetext{
${ }^{2}$ Considerando-se que as concentrações estão em ppm.

${ }^{3}$ Estas análises (em destaque no anexo VI) são referentes a amostras provindas de outros afloramentos do $\mathrm{C}^{\circ}$ Pululus (i.e. pontos e perfis selecionados em trabalho anterior de POLO, 2004).
} 


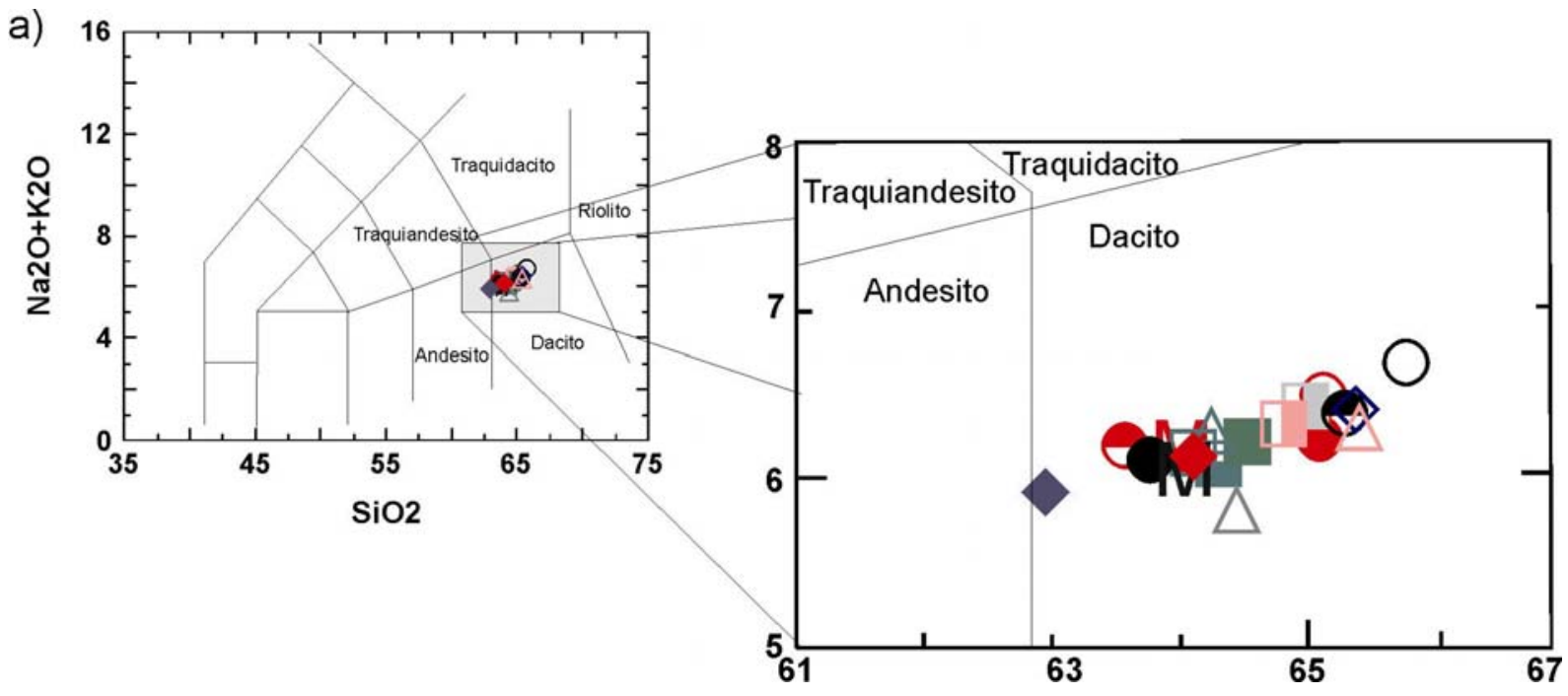

b)

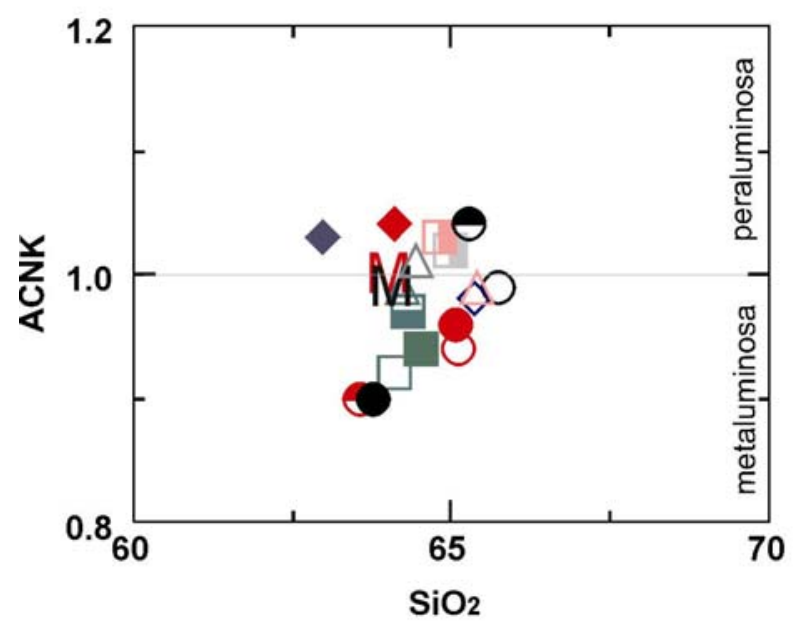

c)

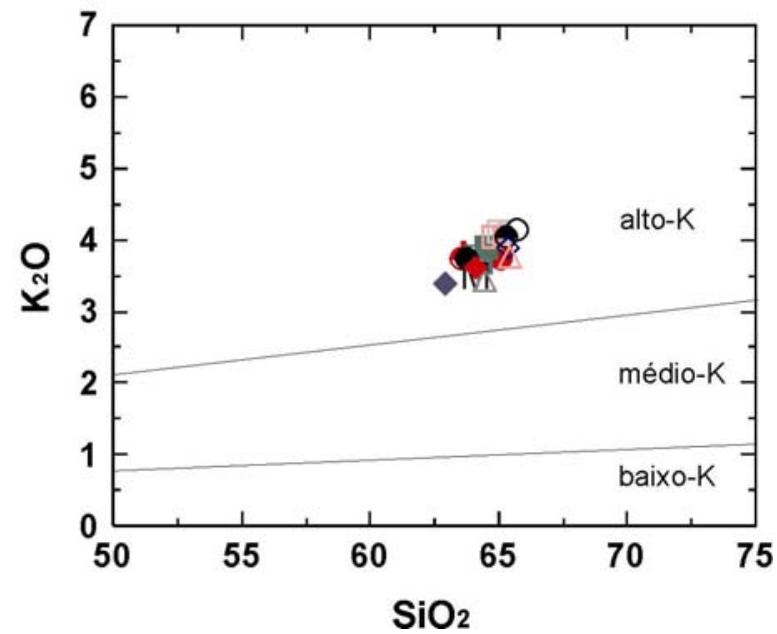

Figura 18 - Diagramas de classificação geoquímica para os depósitos do Co Pululus. a) Diagrama TAS (LE BAS et al., 1986); b) Diagrama de saturação de alumínio $\left(\mathrm{SiO}_{2}\right.$ versus proporções molares de $\mathrm{Al} /(\mathrm{K}+\mathrm{Na}+\mathrm{Ca}))$, mostrando o caráter meta e peralumínoso das rochas do $\mathrm{C}^{\circ}$ Pululus; c) Diagrama de conteúdo em potássio (GILL, 1981), mostrando a alta concentração do elemento (característico dos ignimbritos do APVC). Legenda: UFC: quadrados; UFRI: círculos; UFRS triângulos; CIP: losango azul; Ign. Vilama: losango vermelho; FLP: losango vazio; matriz da UFRI: M vermelho; matriz da UFRS: M preto.

\subsubsection{Unidade de Fluxo Cinza (UFC)}

Conforme podemos observar nos diagramas tipo Harker da Figura 19, a unidade UFC é aquela que apresenta a maior homogeneidade química. Contém alto $\mathrm{K}_{2} \mathrm{O}(3,7$ a $4,12 \%)$ e concentrações de $\mathrm{SiO}_{2}$ variando entre 64,1 e $65 \%$. A maior dispersão é observada do diagrama de $\mathrm{P}_{2} \mathrm{O}_{5}$, que varia entre 0,21 e 0,22\%, uma variação muita pequena se comparada com os demais elementos. 
Para caracterizar essa unidade foram selecionadas amostras da base, meio e topo dos perfis mais representativos da unidade (Perfil-09, em verde nos diagramas; e Perfil-10, em laranja). Analisando os resultados, notamos que o perfil 09 apresenta maiores concentrações que o perfil 10 em todos os elementos, exceto $\mathrm{Al}_{2} \mathrm{O}_{3}, \mathrm{MgO}$ e $\mathrm{Na}_{2} \mathrm{O}$. Essa diferença, como o excesso em $\mathrm{CaO}$ do Perfil-09, indicaria concentrações maiores de plagioclásio ou clinopiroxênio na amostra.

Por outro lado, as variações observadas entre base, meio e topo de cada perfil coincidem na maioria dos casos, com pequenas oscilações na ordem de $0,2 \%$ para $\mathrm{K}_{2} \mathrm{O}$ e $\mathrm{Na}_{2} \mathrm{O}, 0,05 \%$ para $\mathrm{TiO}_{2}, 0,4 \%$ para $\mathrm{CaO}$ e $0,02 \%$ para $\mathrm{P}_{2} \mathrm{O}_{5}$.

\subsubsection{Unidade de Fluxo Rosa Inferior (UFRI)}

Para representar esta unidade foram selecionados púmices pertencentes à base, meio e topo de dois perfis representativos para a unidade (Perfil-03 (em vermelho no diagrama) e Perfil-18 (em preto)). Outras análises apresentadas são referentes à amostra de matriz $(\mathrm{M})$ e ao fragmento lítico plutônico (losango vazio).

Conforme podemos visualizar nos diagramas correspondentes à UFRI (Figura 19), está é a unidade que apresenta maior dispersão quanto aos elementos maiores, com exceção do $\mathrm{K}_{2} \mathrm{O}$, que varia entre 3,75 e 4,13\%, semelhante a UCl. Seu conteúdo em $\mathrm{SiO}_{2}$ varia entre 63,56 e $65,74 \%$.

Analisando apenas os dados de púmices da UFRI (círculos nos diagramas), podemos claramente observar que existe uma pequena variação dentro da unidade, em que as concentrações da maioria dos elementos se comportam de forma oscilatória, permitindo-nos, de tal forma, separar as amostras de base e topo (círculos vazios e cheios, respectivamente) das amostras provindas do meio do depósito (círculos cheios pela metade). A sílica, por exemplo, ocorre em concentrações mais altas na base e no topo do perfil, com valores variando entre 65,1 e $66,1 \%$, do que no meio do depósito, onde a concentração não ultrapassa $63,77 \%$. As concentrações $\mathrm{K}_{2} \mathrm{O}, \mathrm{Na}_{2} \mathrm{O}$ e $\mathrm{Al}_{2} \mathrm{O}_{3}$ também oscilam, apresentando valores mais altos na base e no topo e menores no centro do depósito. Comportamento inverso apresenta o $\mathrm{FeO}, \mathrm{CaO}$ e $\mathrm{MnO}$, com maiores concentrações no meio do depósito.

É interessante ressaltar que a amostra da matriz exibe as mesmas características químicas que as amostras retiradas da porção central do depósito. Já o fragmento lítico (FLP) acompanha principalmente as amostras que representam a base da unidade, em especial a amostra PUL-32, da base do perfil 18 (maiores detalhes sobre a composição geoquímica do FLP serão dados adiante, no item 8.2.4). 
UFC
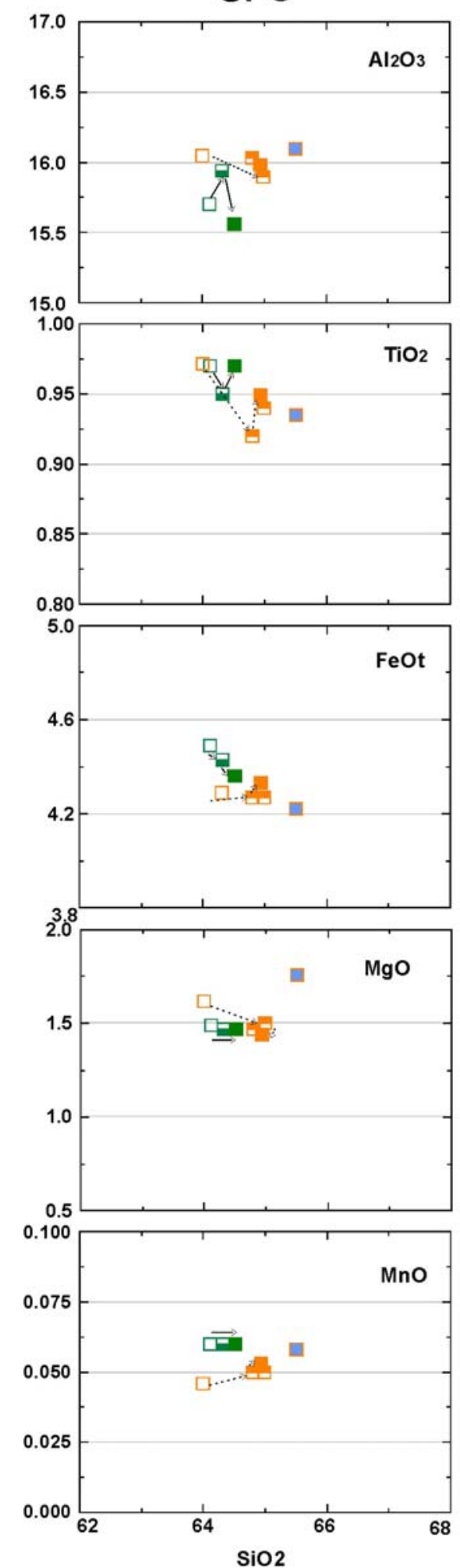

UFRI
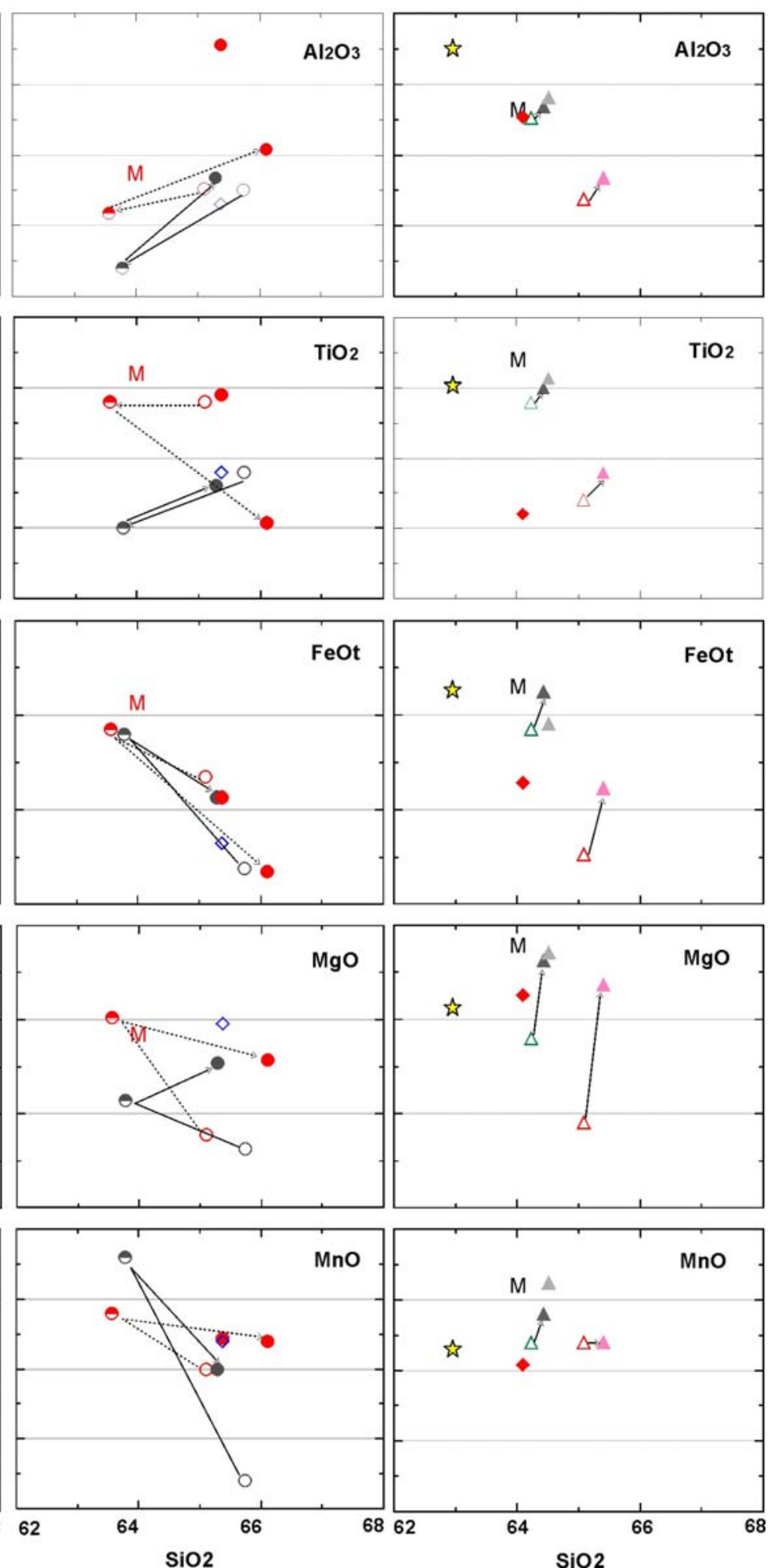
UFC
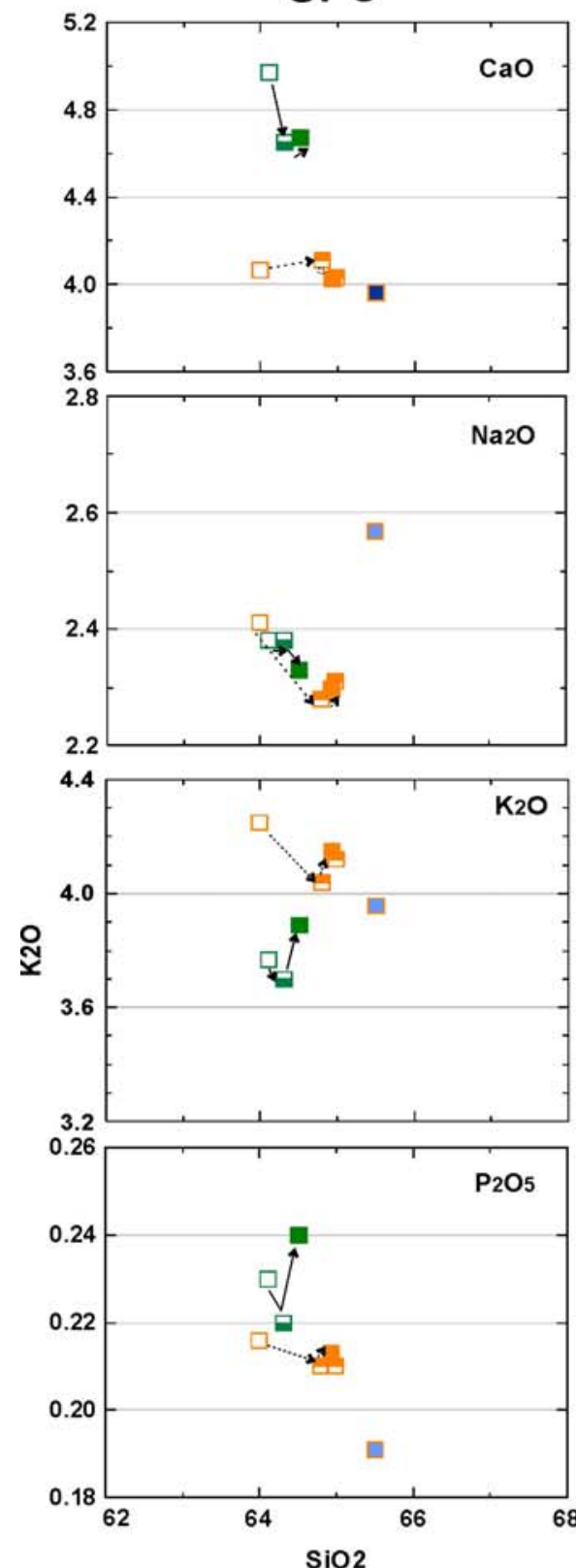

UFRI
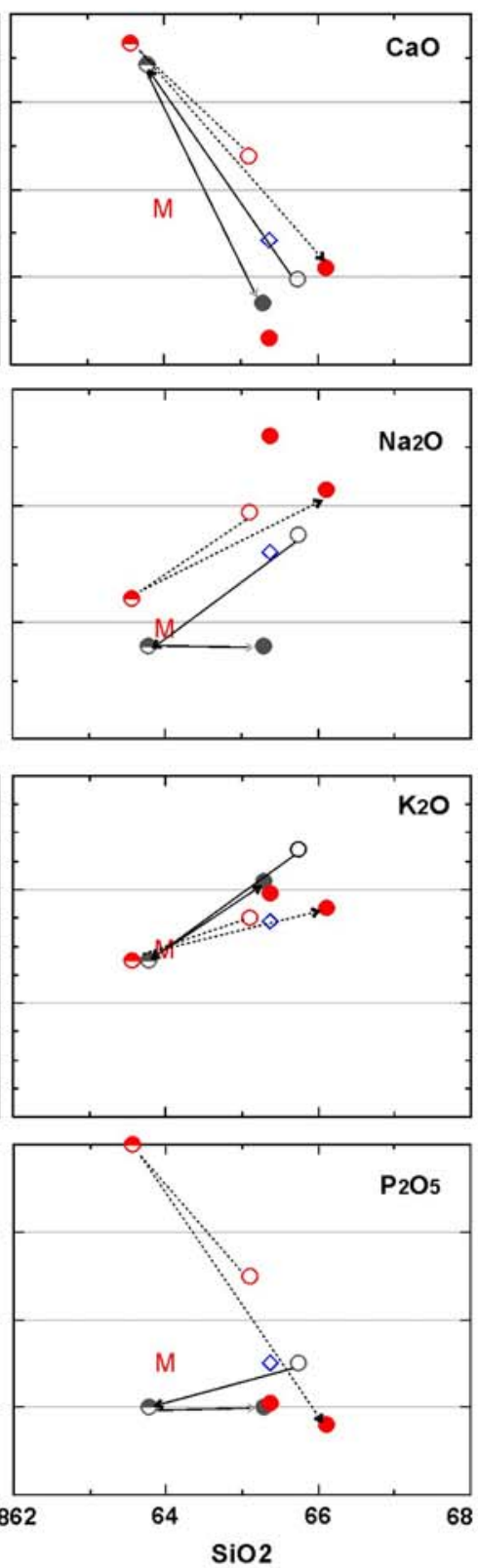

UFRS
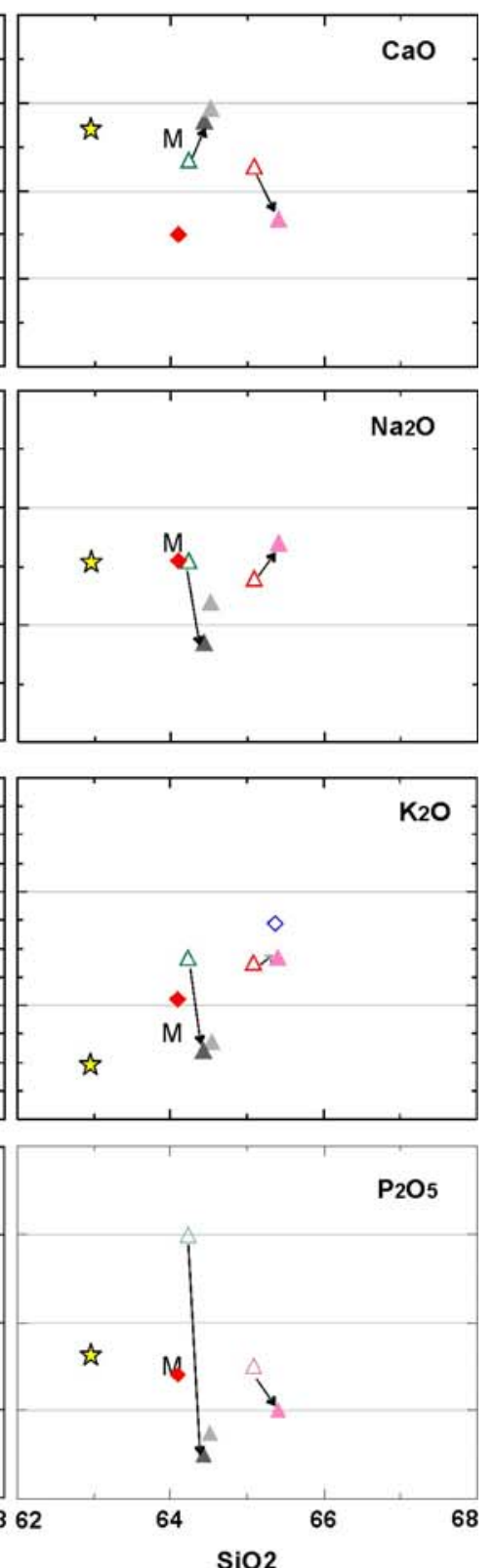

Figuras 19. Diagramas tipo Harker (elementos maiores x SiO2) para amostras representativas de lápillipúmice e matriz das diferentes unidades do cerro.

Símbolos vazios = base da unidade; símbolos cheios pela metade = meio do depósito; símbolos cheios = topo do depósito e $M=$ matriz do ignimbrito (análise de rocha total).

Para cada perfil ou tipo púmice estudado utilizou-se uma cor diferente:

UFC (quadrado): Perfil 9= verde; Perfil 10=laranja;

UFRI (circulo): Perfil3 = vermelho; Perfil 18= preto;

UFRS (triangulo): púmice cinza (tons de cinza) e púmice rosa (tons de rosa);

FLP: diamante vazio;

CIP: diamante vermelho;

Ign. Vilama: estrela. 


\subsubsection{Unidade de Fluxo Rosa Superior (UFRS)}

Para o estudo geoquímico desta unidade foram selecionadas amostras pertencentes à base e ao topo, além de um exemplar de cada tipo de púmice (branco e cinza). Por não haver um perfil contínuo desta unidade, ou seja, de base a topo, consideraram-se como amostras de base (símbolos vazios no diagrama) os púmices localizados próximo ao contato inferior com o topo das unidades $\mathrm{UCl}$ (perfil 09 (púmice cinza)) e UFRI (perfil 03 (púmice branco)). As amostras referentes ao topo (símbolos cheios) são aquelas provindas do cume do Cerro (amostra de matriz, púmice cinza e púmice branco).

Pela Figura 19, observa-se que esta é a unidade que apresenta os mais baixos conteúdos em $\mathrm{K}_{2} \mathrm{O}$, entre 3,4 e 3,77\%; e concentrações em $\mathrm{SiO}_{2}$ semelhantes a UCl, variando entre 64,0 e $65,4 \%$.

Com relação à variação topo e base, esta unidade não apresenta uma tendência evolutiva muito clara, pois amostras do topo e da base distribuem-se de forma dispersa nos diagramas. No entanto, analisando-se separadamente os diferentes tipos de púmices, i.e. os púmices brancos e cinzas, as diferenças composicionais se tornam muito mais evidentes. Por exemplo, amostras de púmices branco, tanto da base (triangulo rosa vazio) como do topo (triangulo rosa cheio), apresentam um caráter mais ácido e mais rico em $\mathrm{K}_{2} \mathrm{O}$. Já os púmices cinzas apresentam concentrações mais altas de $\mathrm{Al}_{2} \mathrm{O}_{3}, \mathrm{TiO}_{2}, \mathrm{CaO}$ e FeOt.

Variações de base a topo da unidade também se tornam mais evidentes. Se observarmos o diagrama de $\mathrm{MgO} \times \mathrm{SiO}_{2}$ (principalmente), além dos valores de $\mathrm{TiO}_{2}$, FeOt, $\mathrm{CaO}, \mathrm{Na}_{2} \mathrm{O}$ e $\mathrm{P}_{2} \mathrm{O}_{5}$, perceberemos que na base do depósito (triângulos vazios) os púmices são mais pobres nesses elementos que no topo do depósito (triângulos cheios).

Ainda mais interessante é comparar os púmices brancos da base da unidade UFRS (triângulos rosas vazios) com as amostras do topo da UFRI (círculos cheios). Ambos púmices apresentam concentrações muito semelhantes em todos os elementos maiores ${ }^{4}$, exceto $\mathrm{Na}_{2} \mathrm{O}, \mathrm{CaO}$ e $\mathrm{K}_{2} \mathrm{O}$.

Para nenhuma das unidade estudadas (UFC, UFRI e UFRS) encontrou-se relação entre valores mais altos de mg\# e menores concentrações de $\mathrm{CaO}$ ou $\mathrm{SiO}_{2}$.

\footnotetext{
${ }^{4} \mathrm{~A}$ variação de $\mathrm{SiO}_{2}$ é inferior a $0,30 \%$.
} 


\subsubsection{Fragmento Lítico Plutônico (FLP)}

O fragmento lítico classifica-se como granodiorito (Figura 18) e, em linhas gerais, apresenta uma composição muito semelhante às demais amostras do cerro. As concentrações de elementos maiores se assemelham à base da UFRS, diferenciandose apenas quanto aos conteúdos de $\mathrm{MgO}$ e $\mathrm{CaO}$, maior e menor, respectivamente.

\subsubsection{Corpo Intrusivo Pululus (CIP)}

O corpo sub-vulcânico que intrudiu os depósitos de Pululus classifica-se como dacito, com teor de $\mathrm{SiO}_{2}$ de 64,1\% (Figura 18). Nos diagramas de tipo Harker (Figura 19) observa-se que os conteúdos em elementos maiores apresentados pelo CIP acompanham o âmbito das demais amostras analisadas, principalmente no que se refere às amostras de matriz, apresentando porém teores mais baixos de $\mathrm{TiO}_{2}$ e FeOt.

\subsection{Elementos Traços e Terras Raras}

Nos diagramas para elementos traços, como os da Figura 20, os dados mostram-se dispersos e não se observa nenhuma tendência particular. As variações que ocorrem entre as distintas amostras são pequenas se tomarmos em consideração a escala em ppm (ver nos diagramas)

Tanto os diagramas de $\mathrm{Sr}$ e $\mathrm{Rb}$ versus $\mathrm{SiO}_{2}$, assim como $\mathrm{Nb}$ versus $\mathrm{Ta}$, evidenciam que, em conjunto, as amostras do $C^{\circ}$ Pululus apresentam uma tendência de variação normal desses elementos. Porém, nenhuma tendência ordenada de diferenciação, ou seja, que obedecesse a estratigrafia proposta (i.e. de base a topo ou entre as unidades: UFC $\rightarrow$ UFRI $\rightarrow$ UFRS), foi de fato encontrada.

Nos diagramas de distribuição de ETR da Figura 21 pode-se observar um maior aporte em ETR/pesados na unidade UFRS e sua respectiva diminuição na unidade UFRI. A unidade UFC apresenta valores muito próximos à UFRS. As concentrações de leves e médios aparentemente não se diferenciam entre as unidades.

Nos diagramas da Figura 22, a semelhança entre os púmices pertencentes à UFC e o púmice cinza da UFRS torna mais evidente a afirmação. É interessante notar que o púmice branco não apresenta o mesmo enriquecimento em ETR pesados e seus valores em traços e ETR se comportam de forma semelhante às amostras pertencentes ao topo e base da unidade UFRI. Já o meio do depósito da UFRI, além de características mais máficas (como observado no item 8.1 sobre elementos 

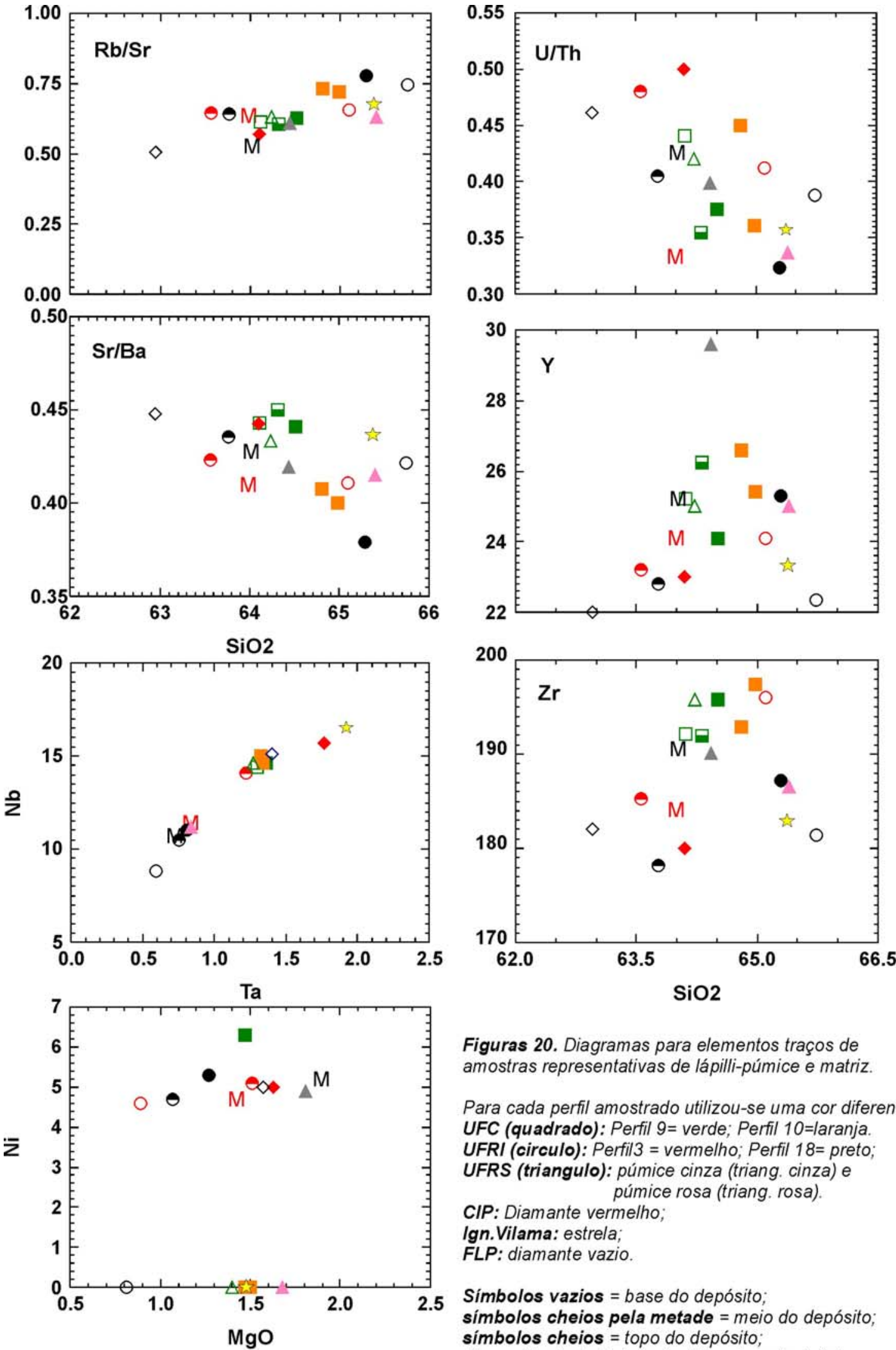

Figuras 20. Diagramas para elementos traços de amostras representativas de lápilli-púmice e matriz.

Para cada perfil amostrado utilizou-se uma cor diferente: UFC (quadrado): Perfil 9= verde; Perfil 10=laranja. UFRI (circulo): Perfil 3 = vermelho; Perfil 18= preto; UFRS (triangulo): púmice cinza (triang. cinza) e CIP: Diamante vermelho púmice rosa (triang. rosa)

Ign. Vilama: estrela;

FLP: diamante vazio.

Símbolos vazios $=$ base do depósito;

símbolos cheios pela metade = meio do depósito; símbolos cheios = topo do depósito;

$\mathbf{M}=$ matriz do ignimbrito (análise de rocha total). 
maiores), apresenta conteúdos próximos aos das amostras do Ign. Vilama e da rocha intrusiva de Pululus. É também interessante observar que as amostras de púmice da UFC e de púmices cinza da UFRS são as que apresentam os valores mais altos em elementos incompatíveis. Quando os dados são representados em diagramas em que se utiliza $\mathrm{SiO}_{2}$ como descriminante observa-se que a variação dos dados segue um padrão oscilatório.

Por meio do estudo petrográfico, sabe-se que os púmices da unidade UFRS apresentam maior quantidade de minerais máficos, tais como clinopiroxênio, ortopiroxênio e anfibólio, o que explicaria os teores um pouco mais altos de $Y$ nessas rochas. No entanto, nenhum desses minerais tem forte influência sobre a concentração de ETR/pesados, como é o caso do zircão.
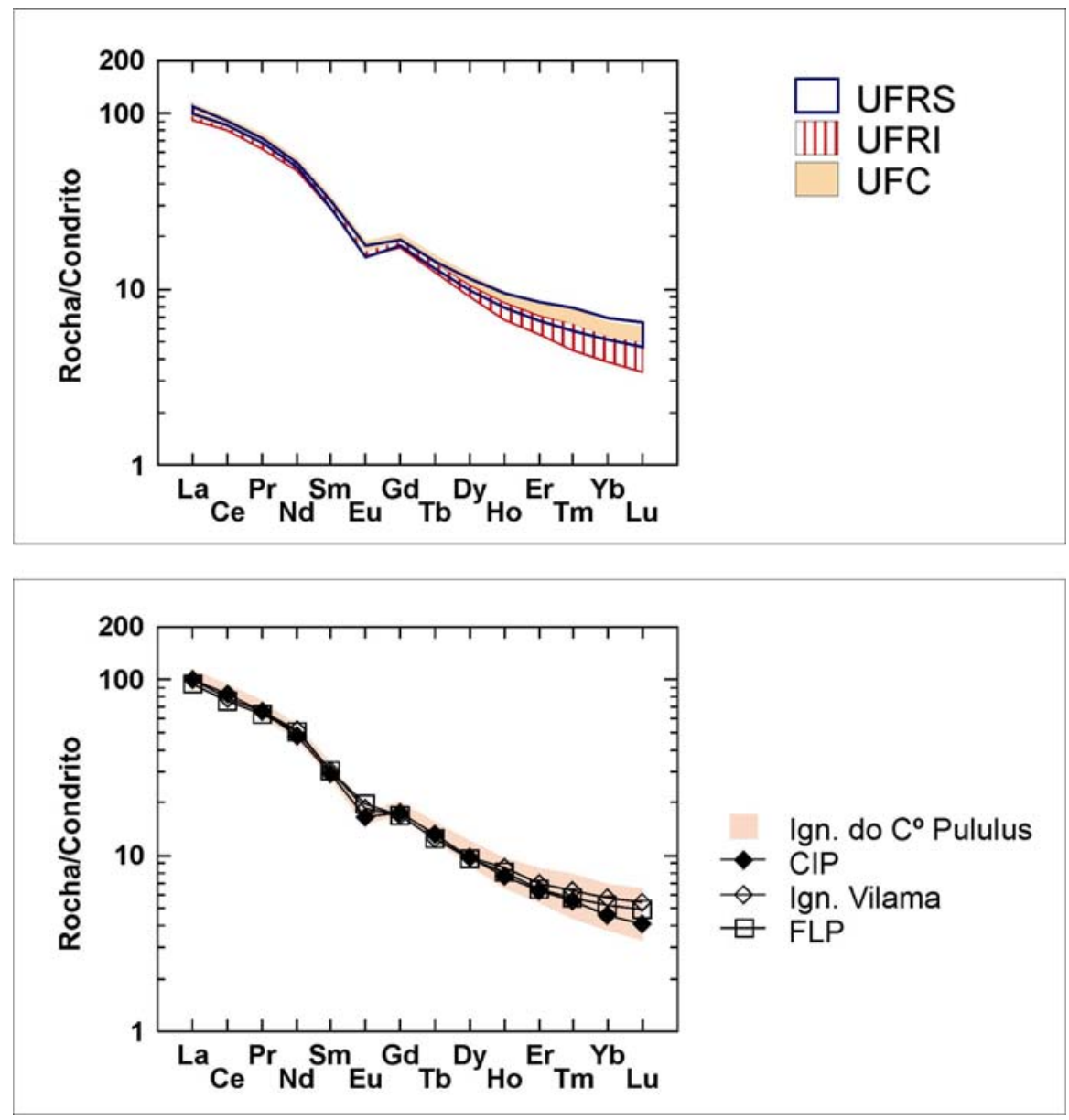

Figura 21. Diagramas de distribuição de Elementos Terras Raras. a) apenas para unidades de fluxo piroclástico do $C^{\circ}$ Pululus, b) Comparação do depósito do $C^{\circ}$ Pululus (unificado) com amostras do CIP, Ign. Vilama e FLP.

Nas rochas estudadas o zircão ocorre apenas como mineral acessório e esporádico, porém, segundo Rollinson (1993), até mesmo em concentrações inferiores a $1 \%$ na rocha, o zircão já pode ter forte influência nas concentrações de 
ETR/pesados. O diagrama ZrxMgO (Figura 20) nos certifica que os púmices das unidades UFC e UFRS apresentam uma maior proporção no elemento zircônio, o que poderia confirmar a hipótese de Rollinson.

Outra observação pode ser feita a respeito da presença de uma anomalia negativa do elemento európio em todas as amostras. Essa anomalia é uma marca característica dos depósitos pertencentes ao CVAP e estaria associada à cristalização de plagioclásio retido no grande batólito APMB (ver item 4.4.2 deste trabalho), empobrecendo a fusão que abasteceu a câmara magmática rasa relacionada a Pululus, assim como ocorreu em outras câmaras e depósitos do CVAP.

Quanto ao FLP, sua composição assemelha-se às composições das amostras da base e do púmice rosa da UFRS, além da matriz analisada da UFRI, reforçando a hipótese de que se trata de um fragmento lítico cognato.
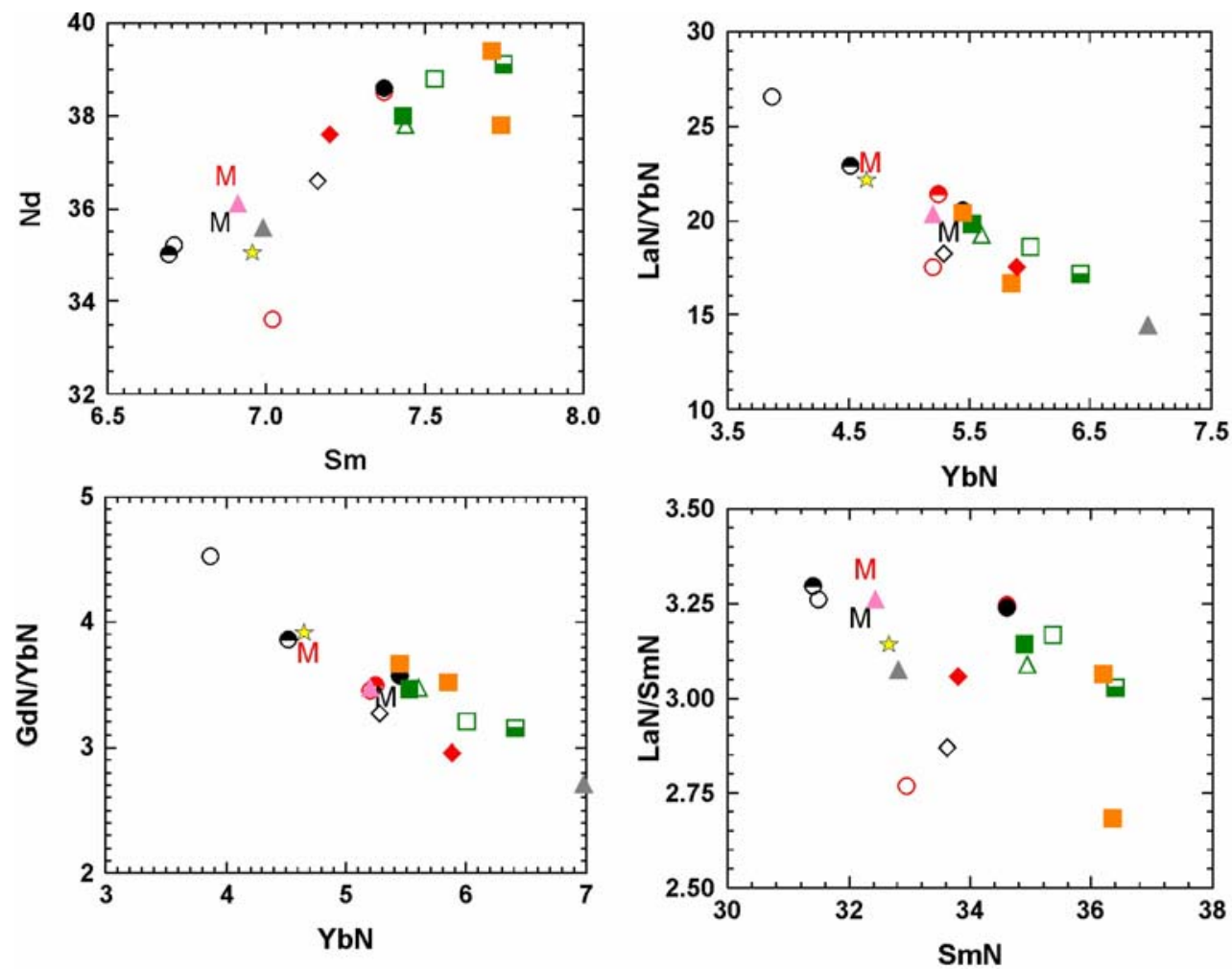

Figuras 20. Diagramas para elementos terras raras normalizados com condrito. Para cada perfil amostrado utilizou-se uma cor diferente:

\begin{tabular}{|c|c|}
\hline $\begin{array}{c}\text { UFC (quadrado): Perfil 9= verde; Perfil 10=laranja; } \\
\text { UFRI (circulo): Perfil } 3=\text { vermelho; Perfil } 18=\text { preto; } \\
\text { UFRS (triangulo): púmice cinza (triang. cinza) e } \\
\text { púmice rosa (triang. Rosa). }\end{array}$ & $\begin{array}{l}\text { CIP: diamante vermelho; } \\
\text { Ign.Vilama: estrela; } \\
\text { FLP: diamante vazio. }\end{array}$ \\
\hline
\end{tabular}

Símbolos vazios $=$ base do depósito; símbolos cheios pela metade = meio do depósito; símbolos cheios = topo do depósito: $\boldsymbol{M}=$ matriz do ignimbrito (análise de rocha total) 


\section{Discussão e Interpretações dos Resultados}

\subsection{Processos de cristalização magmática}

A alta concentração de cristais na matriz (35 a 40\%) e nos púmices (25 a $30 \%$ ) indica que os depósitos de Pululus foram gerados por um magma porfirítico. Essa característica, somada a riqueza em $\mathrm{K}_{2} \mathrm{O}$ nas rochas e as anomalias negativas de Eu nos padrões de TR, é comum na maioria dos depósitos ignimbríticos do APVC. Esse conjunto de feições reforça a hipótese proposta por vários pesquisadores (e.g. de SILVA et al., 2007), no sentido de que os minerais dessas rochas piroclásticas começam a se cristalizar num batólito subjacente (APMB).

Além disso, ao analisarmos as texturas dos minerais dos depósitos de Pululus notamos que alguns dos grandes fenocristais de plagioclásio que apresentam zoneamento truncado, reabsorção parcial e texturas de dissolução no núcleo representam provavelmente os primeiros, ou os mais antigos, cristais de plagioclásio presentes na fusão. Os teores mais ricos em cálcio no núcleo indicam que esses plagioclásios teriam se cristalizado num magma levemente mais máfico, de provável composição andesítica e sob temperaturas mais altas. As texturas de reabsorção representariam, assim, o desequilíbrio que esses cristais sofreram ao se encontrarem em uma fusão de composição dacítica.

Além desses fenocristais de plagioclásio, a enstatita (valor médio: $\mathrm{En}_{72} \mathrm{Wo}_{2} \mathrm{Fs}_{26}$, que exibe formas subédricas com bordas arredondadas e superfícies corroídas, também viria a representar um provável remanescente do magma parental da câmara magmática.

A maioria dos plagioclásios, contudo, representa a fase principal de cristalização do magma, que teria ocorrido após o fundido ser armazenado na câmara magmática a níveis mais rasos da crosta. Tal afirmação baseia-se nas texturas e zoneamentos apresentados por estes plagioclásios, que são características de cristalização em câmaras magmáticas com presença de correntes de convecção. Mais além, esses cristais também podem evidenciar processos de recarga dentro da câmara magmática, por fusões mais máficas. Esse assunto só era tratado no item 9.1.1 deste capítulo.

Junto ao plagioclásio, é provável que a biotita também tenha começado a se cristalizar durante essa fase, o que explicaria a abundância de cristais constituídos 
pelo intercrescimento desses dois minerais. A cristalização de ambos minerais é contínua, até que o processo seja interrompido devido à ascensão e erupção da fusão magmática.

Já a ferrossilita (valor médio: $\mathrm{En}_{44} \mathrm{Wo}_{2} \mathrm{Fs}_{24}$ ), assim como a augita, ocorre como cristais tardios, pois não apenas ambos aparecem englobando a enstatita, como também estão presentes nos púmices, na forma de pequenos prismas inequigranulares euédricos, participando também dos glomérulos de plagioclásio e outros máficos (biotita, enstatita, opacos e mais raramente, hornblenda).

A hornblenda também deve pertencer a essa fase tardia de cristalização, pois aparece de forma esporádica e em pequenos prismas $(<0,3 \mathrm{~mm})$. As maiores concentrações desse mineral são encontradas nos púmices cinzas pertencentes à UFRS, com tamanhos que não ultrapassam 0,2 $\mathrm{mm}$. Mesmo que escassa, as características que a hornblenda exibe podem informar algumas condições préeruptivas do magma, conforme demonstraram os estudos experimentais de Rutherford \& Hill (1993) e Merzbacher \& Eggler (1984) e que serão tratados no item 9.1.2 deste capítulo.

\subsubsection{Evidências de instabilidade na câmara registradas pelo plagioclásio}

Mudanças graduais ou repentinas no estado de equilíbrio associadas com migração, resfriamento e extrusão da fusão podem ser preservadas em discretas zonas texturais ou geoquímicas de alguns minerais (STEWART \& FOWLER, 2001). Sabe-se que o plagioclásio, presente em praticamente todas as rochas relacionadas a arcos vulcânicos, pode ser nucleado a altas temperaturas e persiste durante toda a evolução do magma na câmara mediante a cristalização de fases estáveis na fusão ao redor do cristal inicial (TEPLEY et al., 1999). As variações texturais, morfológicas e composicionais que o plagioclásio apresenta são as feições que refletem esses sucessivos eventos de mudanças nas condições estáveis da câmara magmática (e.g. físicas e químicas), e conseqüentemente, de sua evolução.

Em Pululus, a mais abundante população de plagioclásio pode ser dividida em dois grupos. O primeiro compreende microcristais a fenocristais $(<1,5 \mathrm{~mm})$ euédricos a subédricos, com bordas arredondadas e um discreto zoneamento normal ou oscilatório. A segunda população, com menos exemplares, está composta por fenocristais $(<2,5 \mathrm{~mm})$ que apresentam um zoneamento oscilatório e irregular com feições de desequilíbrio associadas. Essas feições foram identificadas como texturas 
de dissolução (empoeirada e em peneira), e são encontradas tanto nos núcleos - em geral, anédricos - como em distintas zonas internas de diversos plagioclásios, independentemente da composição, i.e. sódico ou cálcico.

Se essas duas populações foram nucleadas e evoluíram no mesmo fundido então elas podem evidenciar as variações físico-químicas que ocorreram na câmara magmática no momento em que foram cristalizadas, pois, segundo Singer et al. (1995), grãos de um mesmo mineral, cristalizados em diferentes porções da câmara sub-vulcânica, irão apresentar distintas histórias evolutivas, devido às variações termais ou químicas encontradas dentro do reservatório, podendo, além disso, ser colocadas lado a lado pela ação das correntes de convecção. Por outro lado, também é possível que essas duas populações tenham sido nucleadas em distintas fusões e que em algum momento da história da câmara e da cristalização entraram em contato por processos de mistura.

Origem das texturas de dissolução:

Tsuchiyama (1985), num estudo experimental sobre as reações entre plagioclásio e fundido, logrou reproduzir diversas texturas de dissolução, semelhantes às que ocorrem na segunda população (e.g. bordas externas ou zoneamentos internos irregulares, cristais arredondados e manteados, texturas em peneira etc.) e concluiu que tais feições são resultado da dissolução parcial do cristal, quando a composição química do mineral não se encontra em equilíbrio com a fusão.

Essas texturas, somadas à presença de cristais com bordas corroídas e cantos arredondados, atestam que as rochas do Cerro Pululus foram geradas dentro de uma câmara magmática com perturbações durante a cristalização. Essas feições podem refletir episódicas injeções de fluidos mais quentes e máficos, instabilidade na pressão, temperatura e taxa de cristalização, além de variações no conteúdo de $\mathrm{H}_{2} \mathrm{O}$ (fortemente influenciada pela velocidade de ascensão do magma pela crosta).

b) Injeções de fusões máficas:

Uma câmara de sistema aberto estará sujeita ao reaquecimento devido à entrada de fundidos mais quentes que se misturam ao fundido pré-existente e que, conseqüentemente, se resfriam. No processo de mistura é evidente que esses câmbios de temperatura (aumento e redução), sofridos em ambos fundidos, induzirão aos processos de dissolução (total ou parcial) de alguns cristais ou a cristalização de duas fases minerais. 
Oscilações no conteúdo de anortita associada à presença de texturas de dissolução (empoeirada e em peneira) são feições comuns nos plagioclásios de Pululus e podem ter sido geradas em resposta a recorrentes injeções de fusões máficas dentro da câmara. É provável que fenocristais euédricos com núcleos mais cálcicos e bordas mais pobres em anortita (e.g. $\mathrm{An}_{82-51}$ ) tenham iniciado sua cristalização na fusão máfica. A borda limpa e com zoneamento extremamente fino, de composição mais sódica, pode representar o momento em que o grão já se encontrava dentro da câmara.

De acordo com Tsuchiyama (1985), as zonas de composição mais cálcica com feições de reabsorção parcial representam o ajuste do plagioclásio pobre em anortita a temperaturas mais elevadas. Sendo assim, um plagioclásio com baixos teores de anortita nucleado e cristalizado dentro da câmara magmática estará mais vulnerável aos processos de reabsorção durante o evento de injeção e mistura de uma fusão mais máfica na câmara, podendo resultar na formação de um "novo" cristal de composição mais cálcica com a preservação de alguns relictos da composição original (i.e. pobres em cálcio), característica observada nas rochas de Pululus.

Outra forte evidência para a entrada de fusões máficas no reservatório é, segundo Singer et al. (1995), o aumento abrupto de 15\%mol de An no plagioclásio, associado a um aumento nos teores de $\mathrm{MgO}, \mathrm{FeO}$ e $\mathrm{Sr}$ e diminuição em $\mathrm{Ba}$ e $\mathrm{K}_{2} \mathrm{O}$ (e.g. HATTORI \& SATO, 1996). Nenhuma dessas variações, porém, foi identificada nos grãos analisados.

Por último, a diversidade de texturas presentes nos plagioclásios, associada à pequena sistematização da composição, tanto nos núcleos $\left(A n_{46}-A n_{85}\right)$ como nas bordas $\left(A n_{33}-A n_{83}\right)$, permite deduzir que, se houve mistura de fusões, esta mistura foi incompleta, ou seja, não houve homogeneização no magma (e.g. TSUCHIYAMA, op. cit.).

c) Correntes de convecção na câmara magmática

Correntes de convecção numa câmara magmática produzem flutuações termais que resultam em oscilações nos teores de anortita do plagioclásio. Porém magmas dacíticos ricos em cristais (entre 50 e 60\%) tendem a apresentar baixas temperaturas (aproximadamente $800^{\circ} \mathrm{C}$ ) e, conseqüentemente, altas viscosidades, 0 que torna desfavorável a formação dessas correntes. Christiansen (2005) calculou uma viscosidade de $10^{5.3} \mathrm{~Pa} / \mathrm{s}$ para um magma dacítico rico em cristais a $800^{\circ} \mathrm{C}$ e $3,8 \%$ em peso de $\mathrm{H}_{2} \mathrm{O}$. Segundo o autor, magmas nessas condições, pouco tempo antes que ocorra a erupção, tornam-se "mortos" - no sentido de movimentos de convecção - 
e cita diversos autores (e.g.: Lindsay et al. 2001b, Bachmann et al., 2002) que estudaram depósitos ignimbríticos dacíticos semelhantes aos de Pululus, concluindo que as barreiras reológicas para a convecção do magma e separação fenocristal-fusão são significantes nos casos em que a viscosidade do magma é de aproximadamente $10^{6} \mathrm{~Pa} / \mathrm{s}$.

É certo que movimentos de convecção da fusão possam ter participado, em algum momento, da história da câmara magmática do Cerro Pululus, a julgar pela presença de cristais limpos de plagioclásio com zoneamento oscilatório nas rochas. No entanto, pelo que foi exposto acima, essas correntes teriam atuado apenas durante um breve período, pouco antes do magma alcançar essas altas taxas de cristalinidade.

\subsubsection{Condições pré-eruptivas do magma registradas pela hornblenda}

Rutherford \& Hill (1993), ao estudarem as rochas do Monte Sta. Helena (EUA), analisaram a presença de bordas de reação nos fenocristais de anfibólio, concluindo que o magma dacítico teria sofrido uma lenta descompressão durante sua ascensão e possivelmente, mas não necessariamente, perda de água dissolvida. No mesmo trabalho, por meio de estudos experimentais da quebra do anfibólio e de suas bordas de reação, determinaram velocidades ascendentes do magma entre 15 e 50 $\mathrm{m} / \mathrm{h}$, velocidade de ascensão relativamente baixa e coerente com a velocidade proposta por Devine et al. (1998) para instabilidade do anfibólio durante a erupção do Monte Soufrière Hills, de Montserrat.

Para que não haja bordas de reação, ou então quebra do anfibólio, Rutherford \& Hill (op. cit.) sugerem que o magma deve ascender a velocidades que excedam os $66 \mathrm{~m} / \mathrm{h}$, pois o equilíbrio da hornblenda depende da fugacidade de $\mathrm{H}_{2} \mathrm{O}, \mathrm{F}, \mathrm{Cl}$ e O , bem como das mudanças de pressão e de temperatura. Segundo Merzbacher \& Eggler (1984), a concentração de água necessária para estabilizar o anfibólio em magmas andesíticos-dacíticos é de 3 a $5 \%$ em peso, um pouco mais alto que a necessária para estabilizar a biotita.

Em Pululus, os anfibólios mais frescos e sem bordas de reação correspondem aos pequenos e abundantes prismas que se concentram nas camadas máficas dos púmices pertencentes à UFRS. Nos depósitos da UFC e UFRI, o anfibólio está praticamente ausente e quando presente exibe espessas bordas de oxidação podendo, além do mais, ocorrer completamente substituído por um agregado de fina granulometria, constituído por minerais máficos, plagioclásio e opacos. 
As observações de Rutherford \& Hill (1993) no tocante à presença de espessas bordas de reação nos anfibólios nos levam a considerar que o início do evento eruptivo (correspondente à UFC) teria sido marcado pela ascensão do magma com velocidade consideravelmente baixa, permitindo a liberação de uma grande quantidade de voláteis e resultando numa erupção de caráter explosivo.

A abertura do sistema e o abatimento da pressão podem ter propiciado uma aceleração na cristalização da fusão que ainda se encontrava na câmara, resultando no progressivo aumento de saturação de água e a conseqüente estabilização e cristalização do anfibólio, conforme observado nos depósitos da UFRS. A melhor preservação do anfibólio e da biotita também poderia estar relacionada com um aumento na velocidade de ascensão do magma pela crosta, porém a mudança de velocidade não teria sido muito contrastante, considerando as próprias características do magma carregada de fases sólidas, tal como mencionado no trabalho de Christiansen (2005).

\subsubsection{Outras evidências}

A exemplo do plagioclásio e hornblenda, outros minerais exibem diversidade de formas ou texturas que também podem evidenciar condições de cristalização ou de instabilidade na câmara:

a) O quartzo, por exemplo, ocorre como cristais poiquiliticos anédricos, fenocristais hexagonais euédricos, ou como grãos arredondados ou embainhados, o que sugere um desequilíbrio termal, com pelo menos um evento de dissolução (e.g. NISHIMURA, et al. 2005).

b) As concentrações de inclusões fluidas que acompanham algumas superfícies de dissolução em uma ou mais zonas do plagioclásio representam, segundo Nishimura et al. (2005), líquidos que foram retidos durante o rápido crescimento do cristal após algum evento de desequilíbrio, associado talvez a flutuações térmicas no reservatório (movidos por correntes de convecção) ou injeções de fusões mais máficas, que também favoreceria o aumento em $\mathrm{pH}_{2} \mathrm{O}$. Segundo os autores, a superfície de dissolução do cristal torna-se favorável para que o líquido se pegue ao mineral e seja então atrapado durante o subseqüente crescimento (NISHIMURA, op.cit.).

c) Os nódulos observados em amostras de púmices também são uma forte evidência de desequilíbrio ou de injeções máficas. Os núcleos constituídos por plagioclásio parcialmente reabsorvido e o posterior preenchimento de seus vazios por 
piroxênio evidenciam momentos de instabilidade do primeiro e a subseqüente cristalização do mineral máfico. O crescimento de minerais máficos e opacos com orientação radial podem ser indicativos de rápido resfriamento, correspondendo talvez ao momento em que fusão máfica penetra na câmara magmática na qual o fundido está a temperaturas mais baixas. O manteamento deste nódulo por plagioclásio de composição sódica e inclusões de microcristais euédricos de composição máfica confirmam o restabelecimento do equilíbrio.

\subsection{Pequenas heterogeneidades composicionais dos depósitos}

Em linhas gerais, sabe-se também que a presença de distintos púmices em um mesmo depósito piroclástico pode indicar uma heterogeneidade na câmara magmática, associada talvez à mistura de fusões caracteristicamente distintas. No caso dos depósitos ignimbríticos do $C^{\circ}$ Pululus foram identificados 2 tipos de púmices (cinza e branco/rosa) que se diferenciam não apenas pela cor, como também pela granulometria dos fenocristais, vesicularidade e composição. Além disso, conforme apresentado no capítulo 8 , os púmices do Cerro Pululus exibem pequenas variações químicas no tocante aos elementos maiores e terras raras, fato que é muito mais evidente na unidade UFRI, em que se observa um comportamento oscilatório de alguns elementos químicos ao longo de seções de base a topo do depósito.

Essas oscilações poderiam ser explicadas como resultado de pequenas heterogeneidades na câmara devido, talvez, à grande extensão da mesma, associadas a eventos de recarga por outras fusões e à baixa efetividade das correntes de convecção (pelas mesmas razões já citadas no item 9.1.1.c).

A falta de um zoneamento mineralógico ou uma variação química mais sistemática no depósito evidencia que processos de cristalização fracionada não foram efetivos devido à alta cristalinidade do magma e à dificuldade de separação entre fluido e cristais.

A geometria da câmara também tem um importante papel nos processos de homogeneização da fusão no seu interior. Estimamos que uma forma alongada e delgada dificultaria a formação das correntes de convecção e a separação dos cristais, propiciando a formações de bolsões ao longo do reservatório (e.g. LINDSAY, 2001b). 


\section{Relação dos depósitos de Pululus com ignimbritos da Caldeira Vilama}

O local de origem dos fluxos piroclásticos (i.e. boca de emissão) que resultaram na formação do $\mathrm{C}^{\circ}$ Pululus ainda não é conhecido, da mesma forma que ainda são incertas a relação e a posição estratigráfica com outros depósitos do APVC e particularmente com os depósitos da Caldeira Vilama.

O $\mathrm{C}^{\circ}$ Pululus apresenta bordas escarpadas, com paredes de 10 a $50 \mathrm{~m}$ de altura, que faz com que o cerro se destaque em meio à planície circunvizinha. Devido a isso, o cerro sempre foi citado em trabalhos de reconhecimento regional como uma unidade piroclástica em forma de escudo, apesar de estudos geológicos de detalhe nunca terem sido realizados.

A partir do trabalho de Coira et al. (1996a,b) o $C^{\circ}$ Pululus passou a ser considerado como unidade piroclástica pertencente a fase pós-colapso da Caldeira Vilama, que teria ocorrido entre o Pleistoceno-Plioceno. Segundo os autores, os fluxos foram lançados a partir de uma boca eruptiva de orientação NO, coincidentes com as fraturas anelares sub-paralelas às estruturas de colapso do sistema caldérico, depositando-se na porção central da depressão de Vilama, por cima do ignimbrito homônimo.

Soler (2005), ao mapear novamente os depósitos da caldeira Vilama e reinterpretar sua origem, termina por excluir os depósitos do $\mathrm{C}^{\circ}$ Pululus do sistema, figurando no mapa do autor como um depósito ignimbrítico pós-caldérico que data do Plio-Pleistoceno, depositado acima do Ign. Vilama e do lado externo da depressão caldérica; sem qualquer relação com a fase ressurgente da mesma.

O presente trabalho, que teve por objetivo estudar em detalhe a gênese e a deposição dos fluxos ignimbríticos que conformam o $\mathrm{C}^{\circ}$ Pululus, oferece a possibilidade de realizar uma correlação entre Pululus e os depósitos pertencentes à caldeira Vilama com base, não apenas nas características em campo, mas em estudos petrológicos e geoquímicos.

O que leva à realização dessa comparação é a homogeneidade química apresentada pelas rochas do $\mathrm{C}^{\circ}$ Pululus, sugerindo que as mesmas não foram geradas em uma pequena câmara magmática, pois, de acordo com Silva e Francis (1991), "os ignimbritos dacíticos de menor volume do CVAP, não parecem apresentar relação com as típicas morfologias de caldeira e são produtos gerados por pequenas câmaras magmáticas zonadas devido a sua variação textural e composicional". 
Para comparação serão utilizados os trabalhos mais recentes sobre a caldeira Vilama, de autoria de Soler (2005) e Soler et al. (2007). As unidades a serem comparadas são: UFC, UFRI e UFRS de Pululus com UEI, UESb e UESt de Vilama, respectivamente.

\subsection{Estratigrafia do Ign. Vilama}

Soler (2005) expõe que o evento de colapso da caldeira Vilama teria sido o responsável pela geração de um único fluxo piroclástico que se depositou nas áreas interna e externa da caldeira, sendo denominado Ign. Vilama intra e extra-caldeira, respectivamente. Segundo o autor, o Ign. Vilama extra-caldeira está integrado por 2 unidades de resfriamento, que corresponderiam a diferentes etapas de formação da estrutura caldérica.

A primeira delas, denominada por Soler (2005) como "Unidad de Esfriamiento Inferior" (UEI), apresenta características muito contrastantes ao restante do depósito e seus principais afloramentos localizam-se a SW e N-NE do $C^{\circ}$ Pululus (Figura 08), com espessuras de que variam de $<1$ a $110 \mathrm{~m}$.

Segundo Soler (2005) a UEI é constituída por uma intercalação de depósitos de fluxos ignimbríticos maciços, de cor predominantemente cinza, com soldamento, em geral, ausente a incipiente, e apresentam apenas um tipo de púmice, de cor cinza. São depósitos ricos em púmice e pobres em líticos, com exceção de um depósito de fácies proximal, a oeste da caldeira Vilama (NW do $C^{\circ}$ Pululus) que contém, em abundância, grandes fragmentos líticos.

A segunda unidade foi denominada de "Unidad de Esfriamiento Superior" (UES; SOLER, 2005) e está constituída por um extenso depósito ignimbrítico maciço, sem intercalações e com variação, de base a topo, no grau de soldamento. A zona de soldamento mais intenso (que chega a formar um lava-like ignimbrite em alguns afloramentos) representa a base da unidade (UESb) e seu contato com o topo (UESt) ocorre de forma gradativa. Ambas apresentam uma cor parda-avermelhada em afloramento e de cinza-chumbo a rosa claro em superfícies frescas, com espessuras de até $25 \mathrm{~m}$ para UESb e de até $50 \mathrm{~m}$ para UESt (SOLER, 2005).

\subsection{Petrografia e Química Mineral do Ign. Vilama e do Co Pululus}

Tanto o Ign. Vilama extra-caldeira como as rochas do $C^{\circ}$ Pululus apresentam a mesma assembléia mineralógica, constituída por: plagioclásio, biotita, quartzo, 
ortopiroxênio, \pm clinopiroxênio e \pm hornblenda, além de apatita, zircão e opacos como acessórios. Esses minerais não apenas ocorrem com a mesma freqüência, mas também apresentam as mesmas relações texturais.

\subsubsection{Classificação dos principais minerais constituintes}

A composição dos principais minerais do Ign. Vilama (extra-caldeira) se assemelha à dos minerais do $C^{\circ}$ Pululus.

Segundo Soler (2005), os plagioclásios dos depósitos de Vilama exibem teores de anortita oscilando entre andesina-bytownita $\left(A n_{50-87}\right.$ no centro e $A n_{45-76}$ na borda). Os cristais podem ainda estar ou não zonados, apresentando uma grande variedade textural (e.g. evidências de reabsorção, centros e bordas corroídos, presença ou ausência de zoneamento). Quanto ao piroxênio, sua principal forma de ocorrência é como cristais ortorrômbicos euédricos de enstatita, seguidos em abundância pela ferrossilita. O clinopiroxênio ocorre principalmente no topo do depósito e corresponde ao grupo da augita. Escassos cristais de pigeonita também foram encontrados, porém pertencem a outra fácies do depósito (fácies de composição riolítica na base da UESb que não será tratada neste trabalho). O anfibólio ocorre como cristais euédricos a subédricos de coloração verde e marrom e classifica-se como o magnésio-hornblenda e, mais raramente, tschermakitahornblenda.

\subsubsection{Biotitas}

Os conteúdos de $\mathrm{Ti}, \mathrm{Mn}, \mathrm{Mg}$ e $\mathrm{Fe}$ das biotitas têm sido utilizados com sucesso para correlacionar extensos depósitos ignimbríticos do CVAP (e.g. De SILVA e FRANCIS, 1989; LINDSAY et al., 2001). De acordo com Soler et al. (2007), as biotitas do Ign. Vilama se caracterizam por apresentar uma grande variabilidade no conteúdo de Fe e Mg, assim como uma homogeneidade de $\mathrm{Ti}$ e $\mathrm{Mn}$, o que permite utilizá-la como parâmetro distintivo com outros depósitos do complexo. Essas características, porém, não são condizentes com dados obtidos para as biotitas do $\mathrm{C}^{\circ}$ Pululus.

A partir dos diagramas da Figura 23, observa-se que as biotitas de Pululus apresentam conteúdos mais altos de $\mathrm{Mn}, \mathrm{Ti}$ y $\mathrm{Fe}^{2+}$ que as biotitas de Vilama selecionadas por Soler et al (2007) como as mais características do depósito (círculos vazios). Além disso, as concentrações de $\mathrm{Ti}, \mathrm{Mg}$ y $\mathrm{Fe}^{2+}$ de Pululus são mais uniformes, diferentemente do que ocorre com o $\mathrm{Mn}$, que se comporta de forma mais variável. 
Nos diagramas, também foram inseridas as análises de biotitas pertencentes ao perfil Lagunillas II (amostra M-51 de SOLER, 2005), afloramento localizado a E do cerro Salle e NE de Pululus. Neste caso, as biotitas apresentam uma composição mais semelhante às do $\mathrm{C}^{\circ}$ Pululus, com maior variabilidade no conteúdo de Ti e Mn. É provável que essa semelhança ocorra devido ao menor grau de alteração das biotitas M-51, da unidade UESt de Vilama e das biotitas analisadas neste trabalho para Pululus.

Independentemente do grau de alteração, outros elementos também podem confirmar a correlação entre o Ign. Vilama e o $C^{\circ}$ Pululus. O valor de $\mathrm{mg \#}$ varia entre 0,44 e 0,67 para as biotitas de Pululus e de 0,45 a 0,57 para o Ign. Vilama. A concentração de Ba está entre 0,04 e 0,52 u.p.f.u. tanto para Pululus como para o lgn. Vilama e os altos conteúdos de $F$ de Pululus $(0,13$ a 2,27) são idênticos ao Perfill Lagunillas.
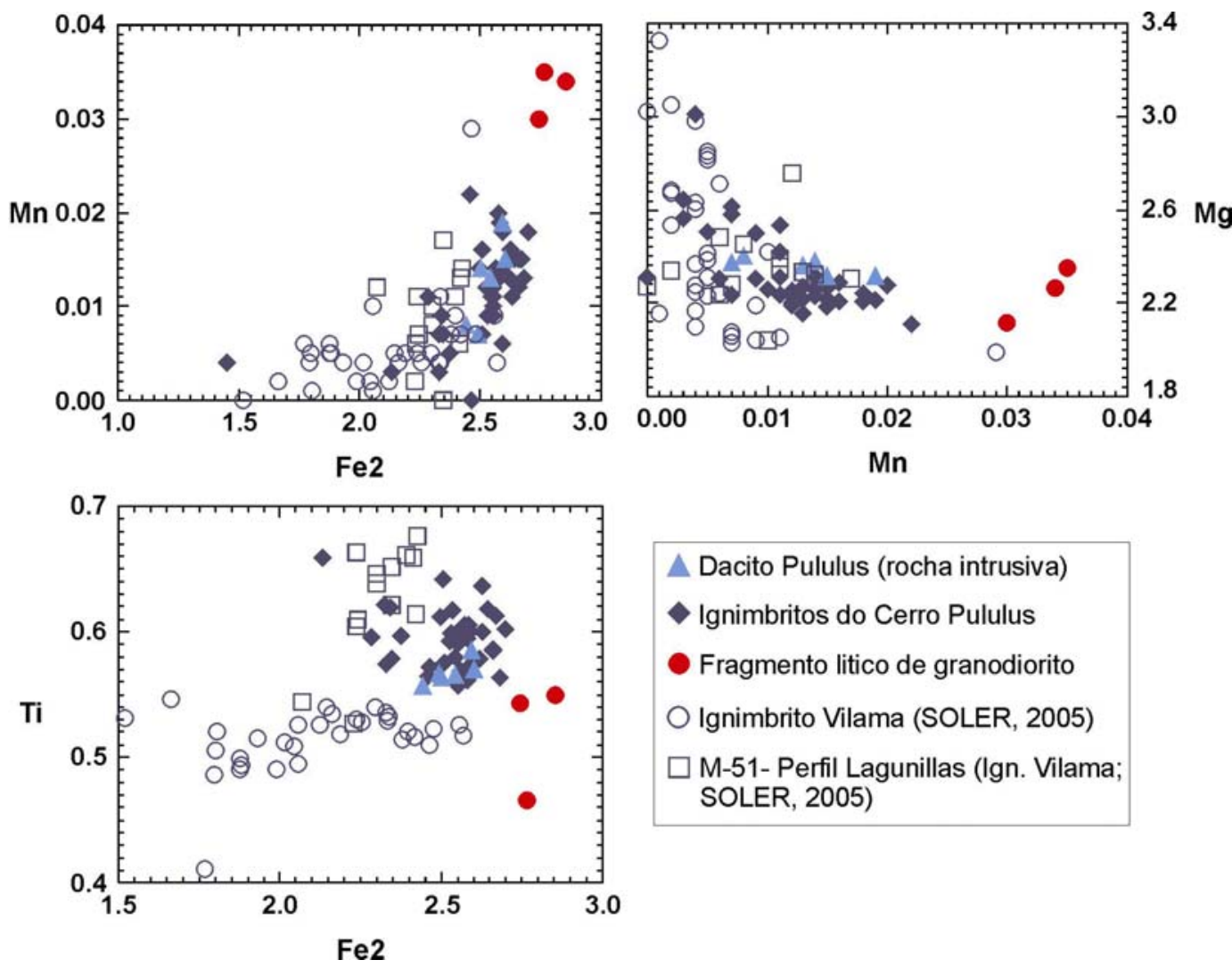

$\triangle$ Dacito Pululus (rocha intrusiva)

Ignimbritos do Cerro Pululus

- Fragmento litico de granodiorito

O Ignimbrito Vilama (SOLER, 2005)

$\square$ M-51- Perfil Lagunillas (Ign. Vilama; SOLER, 2005)

Figura 23. Correlação dos depósitos do $C^{\circ}$ Pululus com Ign. Vilama (SOLER, 2005) a partir da química mineral (Fe-Ti-Mn-Mg) de fenocristais de biotita. Dados em unidade por fórmula unitária (u.p.f.u.) recalculados em $22 \mathrm{O}+2 \mathrm{OH}$. Maiores detalhes no texto. 


\subsection{Geoquímica do Ign. Vilama e do Co Pululus}

Como mencionado no capítulo 08 , as análises geoquímicas de ignimbritos devem ser preferencialmente realizadas em fragmentos juvenis, evitando-se de tal forma possíveis contaminações por parte de xenocristais e fragmentos líticos acidentais ou acessórios recolhidos eventualmente pela passagem do fluxo piroclástico. Contudo, Soler menciona que teve dificuldade para separar os púmices na maioria de suas amostras devido ao alto grau de soldamento em que se encontravam, tendo de realizar suas análises em amostras de rocha total. O autor, no entanto, reconhece que não houve grandes variações entre as análises de rocha total e de púmices que caracterizam o Ign. Vilama e é por isso que utilizaremos com confiança seus dados de rocha total para comparação com as análises de púmices do Co Pululus.

Quimicamente, o Ign. Vilama extra-caldeira (com exceção da fácies riolito descrito por SOLER, 2005) é dacítico cálcio-alcalino de alto- $\mathrm{K}_{2} \mathrm{O}$, com características meta a peraluminosas e índices de saturação de alumina (A/CNK) entre 0,90 e 1,15\% (SOLER, 2005). Para a elucidar a comparação e a semelhança entre os dois depósitos, são apresentados na Figura 24 alguns diagramas de elementos maiores $\mathrm{X}$ $\mathrm{SiO}_{2}$ de análises correspondentes às rochas do $\mathrm{C}^{\circ}$ Pululus e do Ign. Vilama, assim como análises de púmices rico em cristais e de composição dacítica pertencentes a outros depósitos ignimbriticos do APVC, tais como, Ign. Atana (LINDSAY et al,. 2001), Ign. Sifón (DE SILVA e FRANCIS, 1989) e ignimbritos do Complexo vulcânico Coranzuli (SEGGIARO et al., 2001). Também foram inseridos os dados correspondentes ao CIP e FLP de Pululus.

\subsection{Modelos eruptivos}

Os modelos propostos para a geração e deposição dos ignimbritos Pululus, com extensão aproximada de $150 \mathrm{~km}^{2}$, e o Ignimbrito Vilama, com aproximadamente $4.000 \mathrm{~km}^{2}$ (SOLER, 2005), também reforçam a hipótese de correlação devido a sua grande semelhança. Ambos modelos foram elaborados a partir das características observadas nos afloramentos, tais como: espessura do depósito, tamanho e quantidade de fragmentos juvenis e líticos, grau de soldamento, relações estratigráficas etc. 

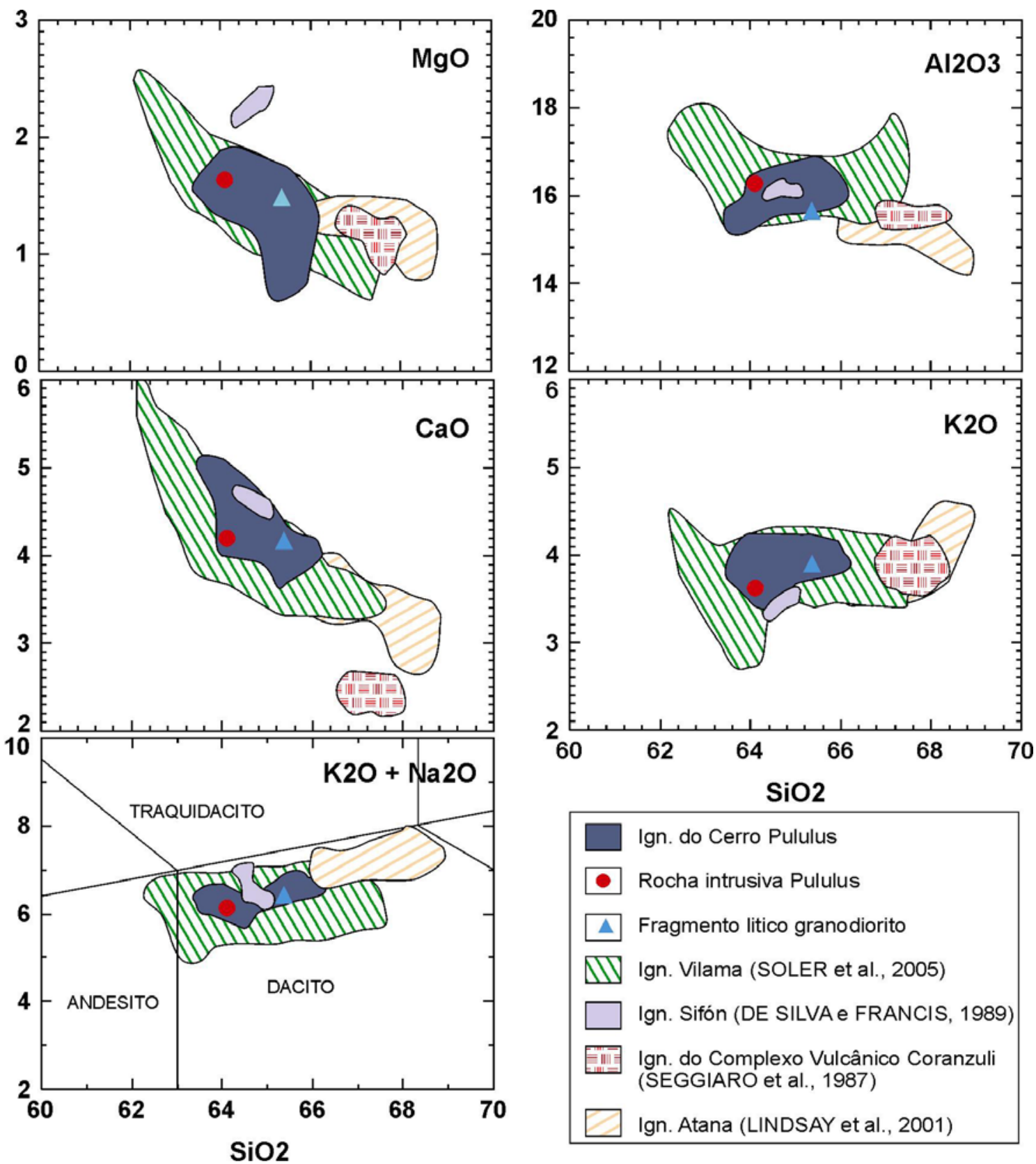

Figura 24. Diagramas do tipo Harker para análises de lapilli-púmice (exceto Ign. Vilama, c/ análise de rocha total) de ignimbritos do APVC e diagrama de classificação TAS (LE BAS et al., 1986).

\subsubsection{Modelo eruptivo para os depósitos do Cerro Pululus}

O modelo eruptivo para o $\mathrm{C}^{\circ}$ Pululus foi primeiramente apresentado em Polo (2004) e sugere que as diferentes unidades de fluxo piroclástico (UFC, UFRI e UFRS) foram geradas a partir de explosões sucessivas, partindo de um mesmo centro emissor. Devido à alta viscosidade e temperatura do magma porfirítico, as explosões 
formaram colunas eruptivas com pouco desenvolvimento vertical, evitando assim uma maior perda de calor.

Durante o primeiro evento explosivo (que corresponde à UFC), algumas feições como a taxa de descarga, e/ou explosividade, e/ou dinâmica de colapso da coluna, teriam variado gradualmente durante a erupção, gerando, num mesmo fluxo, pulsos consecutivos que resultaram em gradações descontínuas no depósito (fácies ${ }^{5}$ ), com a ausência de superfícies de contato. A fácies 1-a indica um maior aporte de fragmentos líticos, que pode estar relacionada à fase de abertura do conduto vulcânico. Pelas características da fácies-1b, pode-se dizer que, durante a passagem da corrente, a cabeça do fluxo teria permitido uma maior entrada de ar externo durante o transporte (ver item 3.3.1), o que provocou turbulência e, conseqüentemente, um rápido resfriamento no depósito. Em seqüência (fácies 2 e 3) o fluxo teria entrado num regime de menor turbulência, comportando-se de forma laminar, o que permitiu uma maior retenção de calor e, assim, um aumento no grau de soldamento.A segunda explosão (UFRI) gerou nuvens mais densas que a erupção anterior, evitando o desenvolvimento vertical da coluna eruptiva e também uma maior perda de calor. $O$ fluxo viscoso e com elevada temperatura comportou-se de forma pouco turbulenta, contribuindo para a formação de um depósito com alto grau de soldamento. O terceiro evento vulcânico (UFRS) teria apresentado características explosivas e de dinâmicas de fluxo semelhantes à UFRI. O fluxo denso e quente teria se comportado de forma laminar, depositando-se como uma fina capa sobre as demais unidades (<10 m de espessura).

A distribuição dos depósitos foi fortemente influenciada pela topografia, contribuindo assim para a formação de depósitos do tipo HARI (dentro de paleovales), com zonas de soldamento associadas, tanto para a UFC como para a UFRI. A UFRS, por outro lado formou um depósito do tipo LARI.

A ausência de variações laterais nos depósitos, assim como de qualquer indicio de fácies proximal no alto do cerro (e.g. brechas co-ignimbriticas), impossibilitou definir a localização da boca de emissão dos fluxos piroclásticos.

\subsubsection{Modelo eruptivo para o Ign. Vilama (SOLER, 2005; SOLER et al., 2007)}

\footnotetext{
${ }^{5}$ Não se deve descartar, contudo, a possibilidade de que, em vez de fácies, essas variações representem diferentes unidades de fluxo que se depositaram em curtos intervalos de tempo e se resfriaram em conjunto, formando uma Unidade de Resfriamento Composta.
} 
Segundo os autores, o Ign. Vilama depositou-se durante o evento de formação da caldeira Vilama, sendo que a maior parte do material foi depositada dentro da estrutura colapsada (intra-caldeira) e só uma pequena parcela constitui os depósitos de extra-caldeira.

O início do colapso teria sido o responsável pelo disparo da erupção, que gerou colunas eruptivas bem desenvolvidas e com fases convectivas bem eficientes (tipo Pliniano), além disso a menor dimensão da boca de emissão, menor taxa de ascensão do magma e um maior conteúdo de voláteis no teto da câmara magmática teriam contribuído para o caráter mais explosivo desta fase que resultou na deposição da unidade UEI. O moderado a alto conteúdo de fragmentos líticos na UEI foi interpretado como produto resultante da abertura dos condutos por onde a câmara foi esvaziada.

Com o melhor desenvolvimento das estruturas de colapso, as condições eruptivas mudaram bruscamente e deu-se início à emissão do material que conforma a unidade UES. Inicialmente, a coluna eruptiva apresentou pouco desenvolvimento vertical e um constante aporte de material, formando fluxos muito quentes. A rápida deposição da unidade UES esteve associada a uma alta taxa de emissão que pode ser alcançada pela maior extensão da boca de emissão ou pela formação de múltiplas fraturas que atuaram simultaneamente como condutos eruptivos. O Ign. Vilama extracaldeira foi classificado como depósito do tipo LARI.

\subsubsection{Discussão e comparação entre modelos}

Para a comparação entre os modelos eruptivos devem-se ter em conta, primeiro, as diferenças de tamanho e volume entre os ignimbritos do $C^{\circ}$ Pululus e o Vilama. Apesar dessas grandes diferenças, existem semelhanças notórias, as quais estão relacionadas abaixo:

1) Ambos conjuntos são compostos de três depósitos. As unidades denominadas UFC, UFRI e UFRS do $C^{\circ}$ Pululus são semelhantes às unidades UEI, UESb e UESt do Ign. Vilama, respectivamente.

2) Ambas unidades da base (UFC e UEI) foram geradas por erupções de caráter mais explosivo, resultando em fluxos com maior turbulência e depósitos com menor grau de soldamento. Ambas não constituem um depósito maciço e são formadas por diferentes depósitos de fluxo que viriam a formar uma unidade de resfriamento composta. Além do mais, a presença de fácies com maior concentração 
de fragmentos líticos pode estar relacionada a fase de abertura de um conduto vulcânico.

3) Os depósitos correspondentes às unidades UFRI e UFRS (Pululus) e UESb e UESt (Vilama) são resultantes de fluxos piroclásticos densos, viscosos e pouco turbulentos, gerados pelo colapso de colunas eruptivas com pouco desenvolvimento vertical. O contato entre a unidade inferior (UFRI e UESb) e a unidade de topo (UFRS e UESt) é gradual, indicando uma taxa de descarga contínua, com alguma variação, porém, no volume e velocidade do material lançado, o que caracteriza as diferenças entre base e topo desses conjuntos (ou seja, variação no grau de soldamento, extensão e espessura). 


\section{Considerações finais}

Com base nos estudos realizados e particularmente nos itens que focalizam as discussões e interpretações sobre os vários aspectos das rochas piroclásticas em estudo, podemos oferecer algumas interpretações a respeito dos ignimbritos do Cerro Pululus e também quanto à correlação desses depósitos com os ignimbritos da Caldeira Vilama.

\subsection{O Cerro Pululus}

11.1.1 $O \mathrm{C}^{\circ}$ Pululus é constituído por três unidades de fluxo ignimbrítico, que possuem de 20 a $30 \%$ de púmices e escassos fragmentos líticos $(<2 \%$ e ocasionalmente $8 \%$ ). Na porção mais elevada do cerro aflora um corpo intrusivo subvulcânico (CIP) que elevou e deformou os depósitos piroclásticos na forma de um anticlinal.

a) Unidade de Fluxo Cinza (UFC): representa a unidade basal e aflora na porção SW do cerro. Caracteriza-se por sua coloração cinza, um tipo de púmice (branco/rosa), soldamento ausente a incipiente e presença de distintas fácies sem superfícies de contato.

b) Unidade de Fluxo Rosa Inferior (UFRI): depósito que aflora na porção oeste e norte do cerro, de cor rosa acinzentada e espessura entre 10 e 60 m. É maciça, com médio a alto grau de soldamento, apresenta dois tipos de púmices (branco/rosa e cinza) e foi afetada por reomorfismo e alteração fase-vapor.

c) Unidade de Fluxo Rosa Superior (UFRS): depósito que cobre as demais unidades do cerro, não ultrapassando $10 \mathrm{~m}$ de espessura. Caracteriza-se por sua cor rosada, grau médio de soldamento e, principalmente, por seu aspecto lajoso. Seu contato com a UFRI é pouco nítido, ocorrendo em diversas ocasiões de forma gradativa. A SW do cerro deposita-se diretamente acima da UFC.

11.1.2 Interpreta-se que esses depósitos tenham sido gerados a partir de explosões sucessivas, partindo de um mesmo centro emissor. Porém como o alto do cerro está completamente coberto pela unidade UFRS, além da ausência de 
variações laterais ou de fácies proximais nos depósitos (e.g. brechas coignimbríticas), não foi possível definir com maior precisão a localização da boca eruptiva que gerou tais fluxos.

11.1.3 A alta concentração de cristais na rocha (50-68\% nos púmices e 23 a $32 \%$ na matriz) indica que os depósitos foram originados por um magma porfirítico. As várias unidades que compõem o cerro apresentam a mesma assembléia mineralógica: plagioclásio (40-61\%), biotita (17-30\%), quartzo (9-24\%), ortopiroxênio (<10\%), clinopiroxênio (<4\%) e anfibólio (<2\%) como minerais principais, além de apatita, zircão e minerais opacos, como acessórios (menos de 1\%).

11.1.4 As feições texturais dos minerais essenciais são fonte importante de informações a respeito do processo de cristalização. Nesse sentido, destacam-se as características do plagioclásio. O mineral possui teores de anortita oscilando entre 43 e $86 \%$ e os cristais podem ser divididos em três grupos:

Grupo-l: são os cristais mais antigos da fusão e ocorrem como fragmentos de fenocristais $(<2 \mathrm{~mm})$ com texturas internas de dissolução e zoneamento oscilatório, truncado por quebra e com sobrecrescimento de uma fina borda irregular mais pobre em anortita.

Grupo-II: são os plagioclásios mais abundantes e representam a principal fase de cristalização do magma. Caracterizam-se por suas formas euédricas $(<1 \mathrm{~mm})$, com zoneamento normal a oscilatório e bordas arredondadas. É comum que apresentem inclusões de biotita ou estejam intercrescidos com a mica.

Grupo-III: são fenocristais $(<2,5 \mathrm{~mm})$ com zoneamento complexo e irregular, texturas internas de dissolução e bordas parcialmente reabsorvidas, apresentando, na maioria das vezes, uma fina borda irregular pobre em anortita. Sua presença nas rochas foi interpretada como uma evidência de recarga de fusões mais máficas dentro no reservatório. 
11.1.5 A biotita ocorre como placas $<2,5 \mathrm{~mm}$ e representa, junto ao plagioclásio do grupo II, a principal fase de cristalização do magma. A geração de mica foi contínua, até o processo ser interrompido durante a ascensão e erupção da fusão magmática.

11.1.6 No tocante aos piroxênios, foram identificados cristais de ferrossilita, enstatita, augita e pigeonita.

a) A ferrossilita $\left(\mathrm{En}_{44-59} \mathrm{Wo}_{2} \mathrm{Fs}_{54-39}\right)$ é o piroxênio mais abundante e está presente como microfenocristais euédricos a subédricos $(<1 \mathrm{~mm})$, com finas a grossas bordas de oxidação e inclusões de plagioclásio e, mais raramente, enstatita. Este mineral foi interpretado como representante de uma fase tardia de cristalização devido à sua fina granulometria e por apresentar inclusões de plagioclásio (do grupo II).

b) A enstatita $\left(\mathrm{En}_{67-76} \mathrm{Wo}_{2} \mathrm{Fs}_{31-22}\right)$ ocorre como cristais subédricos a anédricos, intensamente fraturados, com bordas arredondadas e superfícies corroídas, e também nos núcleos de ortopiroxênios zonados. A enstatita foi considerada como provável remanescente do magma parental.

c) A augita é o clinopiroxênio mais abundante e aparece em prismas isolados euédricos a subédricos ou englobando a ferrossilita e micrólitos de plagioclásio. Apenas um microcristal de pigeonita foi encontrado.

11.1.8 Os anfibólios são magnésio-hornblenda e, ocasionalmente, tschermakitahornblenda. Ocorrem de forma esporádica e com granulometria inferior a 0,3 $\mathrm{mm}$. Estimamos que o mineral pertence à fase tardia de cristalização.

11.1.9 Os dados químicos obtidos em amostras pertencentes às diferentes unidades do Cerro Pululus, incluindo o CIP, indicam que as rochas são de composição dacítica, com conteúdo de $\mathrm{SiO}_{2}$ variando entre 63,56 e 65,74\%. Essas rochas pertencem série cálcio-alcalina rica em potássio, com características meta a 
peraluminosas, razões $\mathrm{A} / \mathrm{CNK}$ variando entre 0,9 e 1,04 e valores mg\# entre 26,77 e 41,65 .

11.1.10 No tocante aos elementos traços e terras raras, os primeiros mostram-se dispersos e não apresentam nenhuma tendência particular. Quanto aos ETR, os púmices cinzas da unidade UFRS, além dos púmices da UFC, revelaram um maior aporte em ETR (Er, Tm, Yb, Lu), o que apenas poderia ser explicado por um eventual excesso no mineral zircão com relação às outras amostras analisadas. Todas as rochas apresentam uma anomalia negativa do elemento európio, marca característica dos depósitos ignimbríticos pertencentes ao CVAP.

11.1.11 As feições texturais dos minerais, em parte mencionadas em itens anteriores, somadas a outras evidências, permitem oferecer um panorama mais completo sobre os processos de cristalização, instabilidades físico-químicas na câmara magmática, além das condições pré-eruptivas.

a) As oscilações no conteúdo de anortita dos plagioclásios, associadas à presença de texturas de dissolução (empoeirada e em peneira), foram geradas como resposta a recorrentes injeções máficas dentro da câmara. Também se considera que os fenocristais euédricos com zoneamento inverso $\left(\mathrm{An}_{82-51}\right)$ do Grupo III foram nucleados na fusão mais máfica. Outras fortes evidências de mistura são proporcionadas pelos freqüentes nódulos de plagioclásio com minerais máficos e grãos opacos encontrados nas rochas. A orientação radial dos minerais ferromagnesianos nesses nódulos pode ser indicativa de rápido resfriamento correspondendo, talvez, ao momento em que a fusão máfica penetrou na câmara magmática.

b) A julgar pela presença de cristais limpos de plagioclásio com zoneamento oscilatório, estima-se que as correntes de convecção possam ter participado, em algum momento, da história da câmara magmática de Pululus. Essas correntes, porém, teriam atuado apenas durante um breve período, antes que o magma alcançasse 
as altas taxas de cristalinidade, tornando desfavorável a movimentação do fundido.

c) As altas taxas de cristalinidade do magma dificultaram também a atuação de processos de fracionamento e a separação entre fluido e cristais, resultando em depósitos que não mostram nenhum tipo de mudança sistemática nos minerais ou na composição química das rochas.

d) Outra evidência da baixa efetividade de correntes de convecção na câmara é fornecida pelo comportamento oscilatório dos elementos químicos, em seções que vão da base ao topo dos depósitos e também pela presença de distintos púmices em uma mesma unidade piroclástica. Essas heterogeneidades devem-se, também, a eventos recorrentes de recarga, por fundidos de composição um pouco diferente.

e) Estimamos ainda que uma câmara de disposição sub-horizontal, com forma alongada e delgada dificultaria a formação das correntes de convecção, assim como a separação dos cristais, propiciando a formação de bolsões com fundidos um pouco diferentes (mais máficos), ao longo do reservatório e impossibilitando a homogeneização no mesmo.

f) Informações a respeito da erupção podem ser obtidas analisando-se as características do anfibólio nas rochas. A presença de hornblenda com espessas bordas de reação, na unidade UFC, nos leva a deduzir que durante o início do evento eruptivo o magma ascendeu a uma velocidade consideravelmente baixa, permitindo a liberação de uma grande quantidade de voláteis, que resultou numa erupção de caráter explosivo. A abertura do sistema e o abatimento da pressão dentro da câmara propiciariam uma aceleração na cristalização do fundido, resultando no progressivo aumento de saturação de água e na conseqüente estabilização e cristalização dos microcristais de anfibólio encontrados nas rochas da UFRS. A melhor preservação do 
anfibólio e da biotita nas rochas poderia estar relacionada a um aumento na velocidade de ascensão do magma. A mudança de velocidade, porém, não teria sido muito contrastante, considerando as próprias características do magma $(>50 \%$ de cristais e alta viscosidade).

\subsection{Correlação com os depósitos da Caldeira Vilama}

A comparação entre os depósitos piroclásticos da Caldeira Vilama e os ignimbritos do Cerro Pululus é feita principalmente com base nas características estratigráficas, na composição química dos minerais, na química de rocha e nas interpretações com respeito aos processos que atuaram na câmara magmática para formação de ambos depósitos. No entanto, deve-se tomar em consideração as grandes diferenças de dimensão entre esses dois ignimbritos, sendo que Soler (2005) realizou um trabalho de índole regional para Vilama, enquanto no presente trabalho de Pululus se oferece um estudo detalhado da estratigrafia, petrografia e química dos minerais.

11.2.1 Ambos ignimbritos são compostos por três unidades de fluxo que apresentam características muito semelhantes, tais como: cor, grau de soldamento, relações estratigráficas, quantidade e tipos de púmices, quantidade e tipos de líticos, assembléia mineralógica e composição química, havendo, inclusive, uma correlação quase perfeita entre as unidades inferiores, médias e superiores. Cabe ressaltar que o Cerro Pululus está localizado na borda externa da Caldeira Vilama e, portanto, interpretamos que ele representa apenas uma extensão do Ignimbrito Vilama extra-caldeira.

11.2.2 Tanto a unidade UEI de Vilama como o UFC de Pululus são depósitos de cor cinza, não soldados, com um tipo de púmice, constituídos por diversas fácies, sendo uma rica em fragmentos líticos. Soler (2005) interpretou as diferentes fácies do depósito UEI como uma seqüência de fluxos piroclásticos maciços resultante do colapso de plumas vulcânicas do tipo Pliniano. Enquanto Polo (2004) interpretou as fácies da UFC como resultado do colapso de uma única coluna piroclástica com variações na taxa de 
descarga e explosividade durante a erupção. Ambos interpretaram a fácies rica em fragmentos líticos como resultante da abertura de um novo conduto vulcânico.

11.2.3 Tanto a unidade UESb de Vilama, como UFRI de Pululus são maciças, de cor rosa-marrom acinzentado, com soldamento variável de médio a alto grau, apresentando dois tipos de púmices e baixos conteúdos em fragmentos líticos. O contato da unidade UESb com UESt, de Vilama, é do tipo gradacional. Por outro lado, o contato entre as unidades UFRI e UFRS, de Pululus, não é nítido, e por esse motivo neste trabalho consideramos que se trata de um contato gradacional. Tanto a UESt como UFRS apresentam um característico aspecto lajoso e podem ser observadas em contato direto com a unidade basal, UEI e UFC, respectivamente. Desse modo, estima-se que o depósito intermediário (UESb de Vilama e UFRI de Pululus) não tem, necessariamente, a mesma extensão que o depósito de topo.

11.2.4 Em linhas gerais, ambos depósitos apresentam as mesmas assinaturas geoquímicas. São rochas dacíticas cálcio-alcalinas de alto- $\mathrm{K}_{2} \mathrm{O}$ com características meta a peraluminosas e razões $A / C N K$ variando entre 0,90 e $1,15 \%$. Suas assembléias minerais tampouco se diferenciam. Ambos têm o plagioclásio como mineral predominante, seguido em abundância pela biotita, quartzo, piroxênio e anfibólio como minerais principais.

11.2.5 As composições químicas dos minerais são praticamente idênticas em ambos ignimbritos. O plagioclásio varia entre An43 e An86. Os piroxênios são augita, enstatita e ferrossilita e o anfibólio (magnésio-hornblenda e tschermakita) ocorre esporadicamente. Os dados químicos das biotitas frescas de Pululus (com valores de mg\# entre 0,45 e 0,57) são semelhantes as raras biotitas frescas de Vilama.

11.2.11 Os trabalhos realizados, tanto em Pululus como em Vilama, demonstram que a câmara, de grandes dimensões, teria uma geometria particular, com disposição sub-horizontal, forma alongada e delgada. Essa conformação particular teria conseqüências diretas no tocante a correntes de convecção, separação de cristais e formações de bolsões de distintas composições. Tal 
como mencionado nos itens relacionados a Pululus (item 11.1.11), os resultados desses processos, somados a episódicos eventos de recarga por fusões máficas, geraram as pequenas heterogeneidades ao longo do reservatório.

11.2.12 Não existem evidências de que os fluxos piroclásticos de Pululus foram lançados a partir de um conduto vulcânico localizado no ponto mais alto do cerro. Nesse local o que existe é um corpo intrusivo (CIP) que penetra e deforma os ignimbritos aí depositados. A inexistência de qualquer conduto vulcânico é mais um elemento para correlacionar Pululus e Vilama. 


\section{Referências Bibliográficas}

Ahlfeld, F., 1945. Geologia de los yacimientos de "Estaño Madera" de Macha (Bolivia) y de yacimientos similares del noroeste argentino. Notas del Museo de La Plata, Instituto del Museo de la Universidad Nacional de La Plata, Tomo X, Geologia, 36.

Ahlfeld, F., 1948. Estudios Geologicos de Yacimientos Minerales de la Provincia de Jujuy, $1^{\circ}$ parte. Universidad Nacional de Tucúman, Instituto de Geologia y Mineria, Public. 455.

Allmendinger, R.W., Jordan, T.E., Kay, S.M., Isacks, B.L., 1997. The Evolution of the Altiplano-Puna Plateau of the Central Andes. Annu. Rev. Earth Planet. Sci, 25, p:139-174.

Angelelli, V., de Brodtkorb, M.K., Gordillo, C.E., Gay, H.D., 1983. Las Especies Minerales de la República Argentina. Servicio Minero Nacional, Ministerio de Economia, Secretária de Insdústria y Mineria, Subsecretaria de Mineria (Publicácion Especial).

Bachmann, O, Dungan, M.A., Lipman, P.W., 2002. The Fish Canyon magma body, San Juan volcanic field, Colorado: Rejuvenation and eruption of an uppercrustal batholith. Journal of Petrology, 43, p: 1469-1503.

Bahlburg, H., 1990. The Ordovician basin in the Puna of NW Argentina and N Chile. Geodynamic evolution from back arc to foreland basin. Geotektonische Forschungen 75, p: 1-107.

Brace, W.F., Kohlstedt, D.L., 1980. Limits on lithospherics stress imposed by laboratory experiments. Journal of Geophysics Research 85, p: 6248-6252

Caffe, P.J.; Trumbull, R.B.; Coira, B.L.; Romer, R.L., 2002. Petrogénesis of Early Neogene Magmatism in the Northern Puna; Implications for Magma Genesis and Crustal Processes in the Central Andean Plateau. Journal of Petrology 43 (5), p: 907-942. 
Cahill, T., Isacks, B.L., 1992. Seismicity and shape of the subducted Nazca plate. Journal of Geophysical Research 97 (B12), p: 17503-17529.

Cas, R.A.F., Wright, J.V., 1987. Volcanic Successions: Modern and Ancient. Chapman and Hall, London. 528p.

Chmielowski, J., Zandt, G., Haberland, C., 1999. The central Andean Altiplano-Puna magma body. Geophysical Research Letters 26, p: 783-786.

Christiansen, E.H., 2005. Contrasting processes in silicic magma chambers: evidence from very large volume ignimbrites. Geology Magazine, 142 (6), p: 669-681.

Claudohos, T.T., Allmendinger, R.W., Coira, B., Farrar, E., 1994. Late cenozoic deformation in the central andes: fault kinematics from Northern Puna, Northwestern argentina and Southwesthern Bolivia. Journal of South American Earth Science, 7, p: 209-228.

Coira, B.L., 1979. Descripcion Geologica de la hoja 3C Abra Pampa, Provincia de Jujuy. Servicio Geologico Nacional Boletín 170, p: 1-90. Buenos Aires.

Coira, B.L., Kay, S.M., Viramonte, J., 1993. Upper Cenozoic Magmatic Evolution of the Argentine Puna - A model for changing subduction geometry. International Geology Review 35 (08), p:677-720.

Coira, B.L., Caffe, P.J.,Diaz, A., Ramirez, A., 1996a. Sistema de Calderas Anidadas del Cenozoico Superior: Vilama- Coruto, Puna (Argentina) - Altiplano (Bolivia). Memorias del XII Congresso Geologico de Bolivia, III, p: 991 - 1002.

Coira, B.L., Caffe, P.J., Kay, S.M., Diaz, A., Ramirez, A., 1996b. Complejo Volcanico Vilama - sistema Calderico del Cenozoico Superior en Puna, Jujuy. XIII Congresso Geologico Argentino y $3^{\circ}$ Congresso de Exploración de Hidrocarburos, Actas III, p: 603-620.

Coira, B.L., Kay, S.M., Perez, E.M.B., Woll, B., Hanning, M., Flores, P., 1999. Magmatic sources and tectonic setting of Gondwana margin ordovician magmas, Northern Puna of Argentina and Chile. In: Ramos, V., Kepie, D. (Eds) Laurentian- Gondwana connections before Pangea, GSA Special Paper. 
Deer, W.A., Howie, R.A., Zussman, J., 1978. Rock-forming Minerals, Volume 2A. Single-chain silicates (2nd ed.). Wiley, New York, 668 p.

De Silva, S.L., 1989a. Altipalno Puna volcanic complex of the Central Andes. Geology 17, p:1102-1106.

De Silva, S.L., 1989b. Geochronology and stratigraphy of the ignimbrites from the $21^{\circ} 30^{\prime} S$ portion of the central Andes of northern Chile. Journal of Volcanology and Geothermal Research 37, p: 93-131.

De Silva, S.L., Francis, P.W., 1989. Correlation of large ignimbrites - Two case studies from the Central Andes of northern Chile. Journal of Volcanology and Geothermal Research 37, p: 133-149.

De Silva, S.L. de, Francis, P.W., 1991. Volcanoes of the Central Andes. Springer, Berlin Heidelberg New York, 216 p.

De Silva, S.L., Gosnold, W.D., 2007. Episodic construction of batholiths: Insights from the spatiotemporal development of an ignimbrite flare-up. Journal of Volcanology and Geothermal Research 167, p: 320-335.

Devine, J.D., Rutherford, M.J., Gardner, J.E., 1998. Petrologic determination of ascent rates or the 1995-1997 Soufrière Hills Volcano andesitic magma. Geophysical Research Letters, 25, p: 3673-3676.

Fracchia, D., Polo, L.A., Caffe, P, Coira, B., 2008. Redefinición estratigráfica de la Ignimbrita Pululus: Consecuencias volcanológicas y metalogenéticas. XVII Congreso Geologico Argentino (inédito).

Freundt, A., Rosi, M. (Eds.) 1998. From Magma to Tephra. Modelling physical processes of explosive volcanic eruptions. Elsevier, Amsterdam, 318p.

Freundt, A., Wilson, C.J.N., Carey, S.N., 2000. Ignimbrites and block-and-ash flow deposits. In: Sigurdsson, H., Houghton, B., McNutt, S.R., Rymer, H. e Stix, J. (Eds.): Encyclopedia of Volcanoes, p: 581-600. Academic Press.

Gangui, A., 1998. Seismic stratigraphy of the Pozuelos basin: Northern Puna, Argentina. X Congreso Latinoamericano de Geología, Buenos Aires. Actas 1, p:12-17. 
Gill, J.B., 1981. Orogenic andesites and plate tectonics. Spinger Verlag, New York, $358 p$.

Gubbels, T.L.; Isacks, B.L.; Farrar, E., 1993. High level surfaces, plateau uplift, and foreland developement, Central Bolivian Andes. Geology 21, p:695-698.

Guest, J.E., 1969. Upper Tertiary ignimbrites in the Andes cordillera of part of Antofagasta Province, northern Chile. Geol. Society America Bulletin 80 (3), p: 337-362.

Gutscher, M.A., Spakman, W., Bijwaard, H., Engdahl, E.R., 2000. Geodynamics of flat subduction: seismicity and tomografic constraints from the Andean margin. Tectonics 19, p: 814-833.

Hattori, K., Sato, H., 1996. Magma evolution recorded in plagioclase zoning in 1991 Pinatubo eruption products. American Mineralogist 81, p:982-994.

Isacks, B.L., 1988. Uplift of the Central Andean Plateau and bending of the Bolivian Orocline. Journal of Geophysical Research 93, p. 3211-3231.

Johnson, M.C., Rutherford, M.J., 1989. Experimental calibration of the aluminiun-inhornblende geobarometer with application to Long Valley caldera (California) volcanic rocks. Geology, 17, p:837-841.

Jordan, T.E., Alonso, R., 1987. Cenozoic stratigraphy and basin tectonic of the Andes Mountains. $20^{\circ}-28^{\circ}$, south latitude. American Association of Petroleum Geologist Bulletin, 71 (1), p: 49-56.

Kay, S.M., Coira, B., Viramonte, J., 1994. Young mafic back-rc volcanic rocks as a guide to lithospheric delamination beneath the Argentine, Puna Plateau. Journal of Geophysical Research, 99 (B12), p:24,232-24,339.

Leake, B.E. (Charmain), 1997. Nomenclature of amphiboles: report of the Subcommittee on Amphiboles of the International Mineralogical Association, Comission on New Minerals and Mineral Names. American Mineralogist, 82, p: 1019-1037. 
Le Bas, M.J., Le Maitre, R.W., Streckeisen, A., Zanettin, B., 1986. A chemical classification of volcanic rocks based on the total alkali-silica diagram. Journal of Petrology, 27 (3), p: 745-750.

Leidig, M., Zandt, G., 2003. Highly anisotropic crust in the Altiplano-Puna volcanic complex of the central Andes. Journal of Geophysical Research 108 (B1), p: 2014.

Lindsay J.M., de Silva, S.L., Trumbull, R.B., Emmermann, R., Wemmer, K., 2001a. La Pacana caldera, N. Chile: a re-evaluation of the stratigrafy and volcanology of one of the world's largest resurgent calderas. Journal of Volcanology and Geothermal Research 106, p: 145-173.

Lindsay J.M., Schmitt A.K., Trumbull, R.B., de Silva, S.L., Siebel, W., Emmermann, R., 2001b. Magmatic Evolution of the La Pacana Caldera System, Central Andes, Chile: Compositional Variation of Two Cogenetic, Large- Volume Felsic Ignimbrites. Journal of Petrology 42 (3), p: 459-486.

Merzbacher, C.; Eggler, D.H., 1984. A magmatic geohygrometer: Application to Mount St. Helens and other dacitic magmas. Geology, 12, p:587-590.

Nishimura, K.; Kawamoto, T.; Kobayashi, T.; Sugimoto, T.; Yamashita, S., 2005. Melt inclusion analysis of the Unzen 1991-1995 dacite: implications for cristallization process of dacite magma. Bulletin of Volcanology, 67, p:648662.

Pichler, H.; Zeil, W., 1972. The Cenozoic Rhyolite- Andesite association of the Chilean Andes. Bulletin of Volcanology, 35 (2), p: 424-452.

Polo, L.A., 2004. Vulcanismo tardio do complexo de caldeiras Vilama-Coruto, Puna Jujenha, Argentina: Evolução vulcânica do Cerro Pululus. Monografia de Trabalho de Formatura. Instituto de Geociências, Universidade de São Paulo.

Rutherford, M.J. , Hill, P.M., 1993. Magma ascent rates from amphibole breakdown: an experimental study applied to the 1980-86 Mount St.Helens eruption. Journal Geophysics Research, 98, p: 19,667-19,685. 
Schmitt A.K.; de Silva, S.L.; Trumbull, R.B.; Emmermenn, R., 2001. Magma evolution in the Purico ignimbrite complex, northen Chile: evidence for zoning of a dacite magma by injection of rhyolitic melts following mafic recharge. Contrib. Mineral Petrology, 140, p: 680-700.

Schnurr, W.B.W., Trumbull, R.B., Clavero, J., Hahne, K., Siebel, W., Gardeweg, M., 2007. Twenty-five million years volcanism in the southern central volcanic zone of the Andes: Geochemistry and magma genesis of ignimbrites from 25 to $27^{\circ} \mathrm{S}, 67$ to $72^{\circ} \mathrm{W}$. Journal of Volcanology and Geothermal Research 166, p: $17-46$.

Sgrosso, P., 1935. Los yacimientos aluvionales de Sn del departamento Rinconada, Província de Jujuy, Direccion Nacional de Geología y Mineria Public., 110 (inédito)

Singer, B.S., Dungan, M.A., Layne, G.D., 1995. Textures and Sr, Ba, Mg, Fe, K and Ti compositional profiles in volcanic plagioclase: Clues to the dynamics of calcalkaline magma chambers. American Mineralogist, 80, p: 776-798.

Smith, R.L., 1960. Zones and Zonal Variations in Welded Ash Flows - shorter contributions to general geology. Geological Survey Professional Paper, 354F, p: 149-159.

Soler, M.M., 2005. Caldera Vilama (Mioceno Superior): Su estratigrafia, evolución magmática y relación con eventos ignimbriticos tempranos. Puna Argentina Altiplano Boliviano. Tese Doutorado. Universidad Nacional de Salta. 358p.

Soler, M.M., Caffe, P.J., Coira, B.L., Onoe, A.T., Kay, S.M., 2007. Geology of the Vilama caldera: A new interpretation of a large-scale explosive event in the Central Andean plateau during the Uper Miocene. Journal of Volcanology and Geothermal Research 164, p: 27-53.

Soler, P. \& Jimenez, C., 1993. Magmatic contraints upon the evolution of the bolivian Andes since late Oligocene times. Second ISAG, Oxford (U.K.), p: 447-451.

Sparks, R.S.J., Self, S., Walker, G.P.L., 1973. Products of Ignimbrite Eruptions. Geology 1 (03), p: 115-118. 
Sparks, R.S.J., Francis, P.W., Hamer, R.D., Pankhurst, R.J., O’Callangham, L.O., Thorpe, R.S., Page, R., 1985. Ignimbrites of the Cerro Galán caldera, NW Argentina. Journal of Volcanology and Geothermal Research 24, p: 205-248.

Springer, M. 1999. Interpretation of heat-flow density in the Central Andes. Tectonophysics 306, p: 377-395.

Stewart, M.L.; Fowler, A.D., 2001. The nature and occurrence of discrete zoning in plagioclase from recently erupted andesitic volcanic rocks, Montserrat. Journal of Volcanology and Geothermal Research 106, p: 243-253.

Tepley, F. J. III, Davidson, J. P. \& Clynne, M. A., 1999. Magmatic interactions as recorded in plagioclase phenocrysts of Chaos Crags, Lassen Volcanic Center, California. Journal of Petrology 40, p: 787-806.

Tsuchiyama, A., 1985. Dissolution kinetics of plagioclase in the melt of the system diopside-albite-anorthite, and the origin of dusty plagioclase in andesites. Contributions to Mineralogy and Petrology 89, p: 1-16.

Turner, J.C.M. \& Mendez, V., 1979. Puna, en segundo simposio de geologia regional Argentina. Academia Nacional de Ciencias, Cordoba, Argentina, p.57-94.

Walker, G.P.L., 1983. Ignimbrite types and ignimbrite problems. Journal of Volcanology and Geothermal Research 17, p: 65-88.

Wilson, C.J.N., Houghton, B.F., 2000. Pyroclastic Transport and Deposition. In: Sigurdsson, H., Houghton, B., McNutt, S.R., Rymer, H. e Stix, J. (Eds.): Encyclopedia of Volcanoes, p: 545-554. Academic Press.

Yuan, X., Sobolev, S.V., Kind, R., 2002. Moho topography in the central Andes and its geodynamics implication. Earth and Planetary Science Letters 199, p: 389402.

Zandt, G., Leidig, M., Chmielowski, J., Baumont, D., Yuan, X., 2003. Seismic detection and characterization of the Altiplano-Puna magma body, Central Andes. Pure and Applied Geophysics 160, p: 789-807. 


\section{ANEXO I}

\section{GLOSSÁRIO DOS TERMOS E EXPRESSÕES UTILIZADOS NO TRABALHO}

Alteração fase-vapor: resulta da percolação de gases e fluidos quentes dentro do depósito durante sua fase de resfriamento, depositando um cimento que reduz os espaços dos poros. Entre os produtos encontram-se tridimita, cristobalita e feldspato potássico.

Axiolítica (textura de desvitrificação): ver esferulito.

Brecha co-ignimbrítica: brechas típicas indicativas das proximidades da cratera do vulcão, constituída por fragmentos líticos de grandes dimensões que não poderiam ser carregadas pelas correntes piroclásticas.

Caldeiras: grandes estruturas de colapso geradas após intensas erupções ( $>50-100$ $\mathrm{km}^{3}$ de magma descarregado) que esvaziam as câmaras magmáticas e conseqüentemente desestabilizam o terreno vulcânico.

Cristaloclastos (fragmentos piroclásticos): cristais livres ou fragmentos angulares que são derivados de magmas porfiríticos e de fragmentos juvenis que foram relançados durante uma atividade explosiva (CAS \& WRIGHT, 1987).

Desvitrificação: envolve a nucleação e cristalização de cristais no vidro vulcânico em temperaturas sub-sólidas. Este processo ocorre em lavas, intrusões rasas e ignimbritos com alto grau de soldamento. As taxas de desvitrificação dependem da temperatura e da composição de soluções aquosas presentes (McPHIE et al, 1993). Os produtos gerados são esferulitos, litofises e textura micropoiquilitica.

Down-sag collapse: Modelo de subsidência para caldeiras, baseado na geometria de subsidência e nas estruturas resultantes do colapso. Este tipo caracteriza-se por apresentar uma subsidência simples, delimitado por bordas topográficas pouco pronunciadas e bordas estruturais pouco definidas (ver detalhes em LOPMAN, 2000).

Esferulitos: estruturas de devitrificação com formas esféricas ou elipsoidais, constituídas por agregados de cristais fibrosos de quartzo e feldspato potássico. Sua morfologia varia de acordo com a temperatura de formação. 


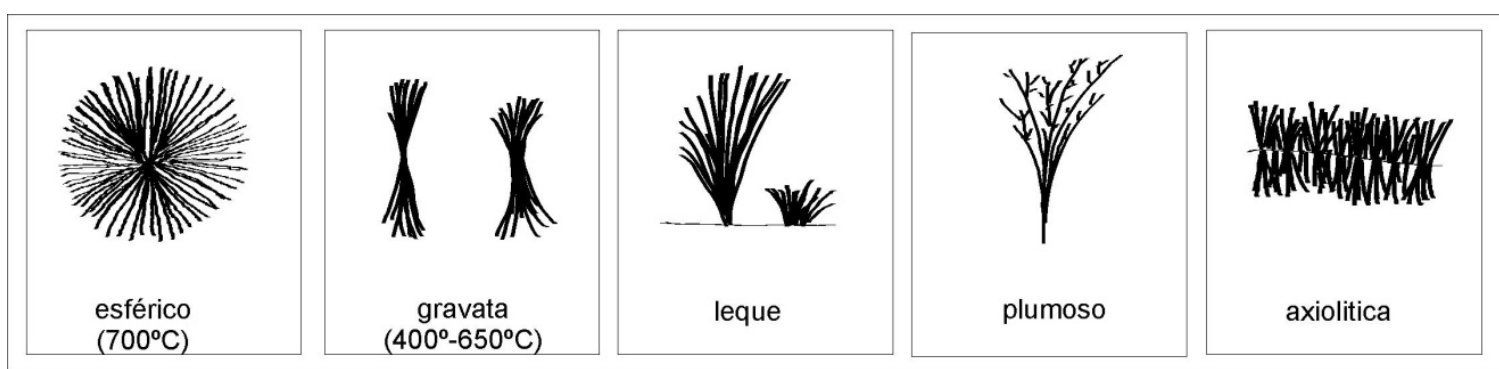

(figura adaptada de LOFGREN,1974 in McPHIE et al, 1993)

Eutaxítica (textura): textura presente na matriz de rochas vulcanoclásticas em resposta ao achatamento e deformação dos estilhaços vítreos (glass-shards) devido as altas temperaturas de deposição e carga sobre-imposta (i.e.soldamento).

Fiammes: púmices achatados e em sigmóide, evidenciando que a rocha foi afetada por soldamento.

Fluxos (correntes piroclásticas): são correntes densas, quentes e turbulentas que descem pelas encostas do vulcão a altas velocidades, geradas pelo colapso de uma coluna eruptiva ou por uma explosão lateral. O colapso (assimétrico ou lateral) ocorre quando a densidade da pluma supera a densidade da atmosfera circundante e não há energia suficiente para sustentá-la (WILSON \& HOUGHTON, 2000).

Fluxos pumícios (Pumice-Flows): Correntes que geram depósitos maciços e mal selecionados de fragmentos de púmice em fração bloco-lapilli (ocasionalmente blocos $>1 \mathrm{~m}$ de diâmetro), imersos em uma matriz de fração cinza constituída por estilhaços vítreos (glass-shards) e cristais.

Fragmentos piroclásticos: São os produtos resultantes da fragmentação do magma e das paredes da rocha encaixante durante uma erupção explosiva. Eles podem ser classificados quanto ao seu tamanho ou quanto a sua origem (CAS \& WRIGHT, 1987).

Glass-shards: são pequenos estilhaços vítreos angulares resultantes da fragmentação explosiva magmática das vesículas do púmice. Morfologicamente os glass-shards podem ter formas variadas semelhantes à letra $Y$ e também formas cuspidadas, características de erupções magmáticas sílico-explosivas. Quando depositados ainda quentes e sob pressão de uma carga sobre imposta os glass-shards podem deformar-se 
plasticamente, como ocorre nos ignimbritos soldados (CAS \& WRIGHT, 1987).

Grau de soldamento: definida pela relação média do comprimento $(\mathrm{cm})$ versus altura (cm) de púmices presentes no depósito.

HARI: (hight-aspect ratio ignimbrites) classificação de Walker (1983) para os depósitos piroclásticos a partir de sua relação $\mathrm{V} / \mathrm{H}$ (V: espessura da unidade; $\mathrm{H}$ : diâmetro de uma área que compreende todos os afloramentos controlados pela topografia). Ignimbritos do tipo HARI limitam-se a ocupar fundos de vales, caracterizando-se como depósitos espessos e de pouco extensão.

Ignimbrito: é a rocha ou depósito formado a partir de um fluxo piroclástico pumício (púmice-flow), independentemente de estar ou não soldado (CAS \& WRIGHT, 1987).

Juvenis (fragmentos): fragmentos vesículados do magma, que podem estar parcialmente cristalizados ou não cristalizados (fragmentos vítreos). A morfologia destes fragmentos pode estar controlada não apenas pelo tipo de magma como também pelo estilo de fragmentação e transporte. Classificamse como fragmentos juvenis os púmices e os glass-shards (CAS \& WRIGHT, 1987).

LARI: (low-aspect ratio ignimbrites) classificação de Walker (1983) para os depósitos piroclásticos a partir de sua relação $\mathrm{V} / \mathrm{H}$ (V: espessura da unidade; H: diâmetro de uma área que compreende todos os afloramentos controlados pela topografia). Ignimbritos do tipo LARI são gerados por eventos cataclísmicos, no qual seus fluxos conseguem ultrapassar barreiras topográficas e rios a altas velocidades, resultando em depósitos extensos e de pouca espessura.

Lava-like ignimbrites: depósitos ignimbriticos maciços e intensamente afetados por soldamento. São reologicamente semelhantes a fluxos de lava.

Líticos (fragmentos): fragmentos de rochas . Representam os componentes densos dentro de um depósito piroclástico. O conteúdo de fragmentos liticos é um bom indicador da competência e estabilidade das rochas que formam as paredes do conduto vulcânico. A composição dos clastos líticos pode ajudar a localizar a posição do boca eruptiva ou indicar a profundidade em que ocorreu a fragmentação. Cas \& Wright (1987) classificam os liticos como: 
$\checkmark \quad$ Cognatos: fragmentos juvenis não vesículados que se solidificaram no magma e foram lançados durante a erupção;

$\checkmark$ Acessórios: fragmentos derivados das paredes da câmara ou do conduto, que também foram ejetadas durante uma explosão ;

$\checkmark$ Acidentais: clastos recolhidos no terreno pela passagem de uma corrente piroclástica.

Os líticos são usualmente angulares, mas em alguns casos podem apresentar-se arredondados, nas proximidades da erupção. Clastos líticos angulares podem também ter sido produzidos por processos de fragmentação de choque à altas temperaturas, auto-brechamento ou por processos epiclásticos (retrabalhamento do material piroclástico).

Perlíto (textura perlítica): delicadas fraturas em formas concêntricas ou linhas curvas, que ocorrem no vidro vulcânico em resposta a hidratação e rápido resfriamento.

Piecemeal collapse: Modelo de subsidência para caldeiras, baseado na geometria de subsidência e nas estruturas resultantes do colapso. Este tipo caracteriza-se por apresentar uma subsidência irregular, composta de vários blocos falhados resultantes do colapso gerado por uma única erupção ou uma série de erupções (ver detalhes em LIPMAN, 2000).

Piston collapse: Modelo de subsidência para caldeiras, baseado na geometria de subsidência e nas estruturas resultantes do colapso. Este tipo de colapso caracteriza-se pela subsidência do piso da caldeira como um único bloco. É provável que este tipo de colapso seja resultante de uma única e grande erupção piroclástica que esvaziou uma camâra magmática rasa, próxima a superfície (ver detalhes em LIPMAN, 2000).

Plumas vulcânicas: são turbulentas colunas convectivas geradas pela fragmentação do magma e sua conseqüente descarga pela boca eruptiva, a altas velocidades. Estas colunas podem estar controladas por diversos fatores, tais como composição do magma, quantidade e natureza dos voláteis, valor de descarga do magma ou geometria da cratera. As plumas podem ser mantidas por um longo período de tempo devido à contínua descarga de 
material pela boca eruptiva ou podem desestabilizar-se gerando correntes de densidade piroclástica.

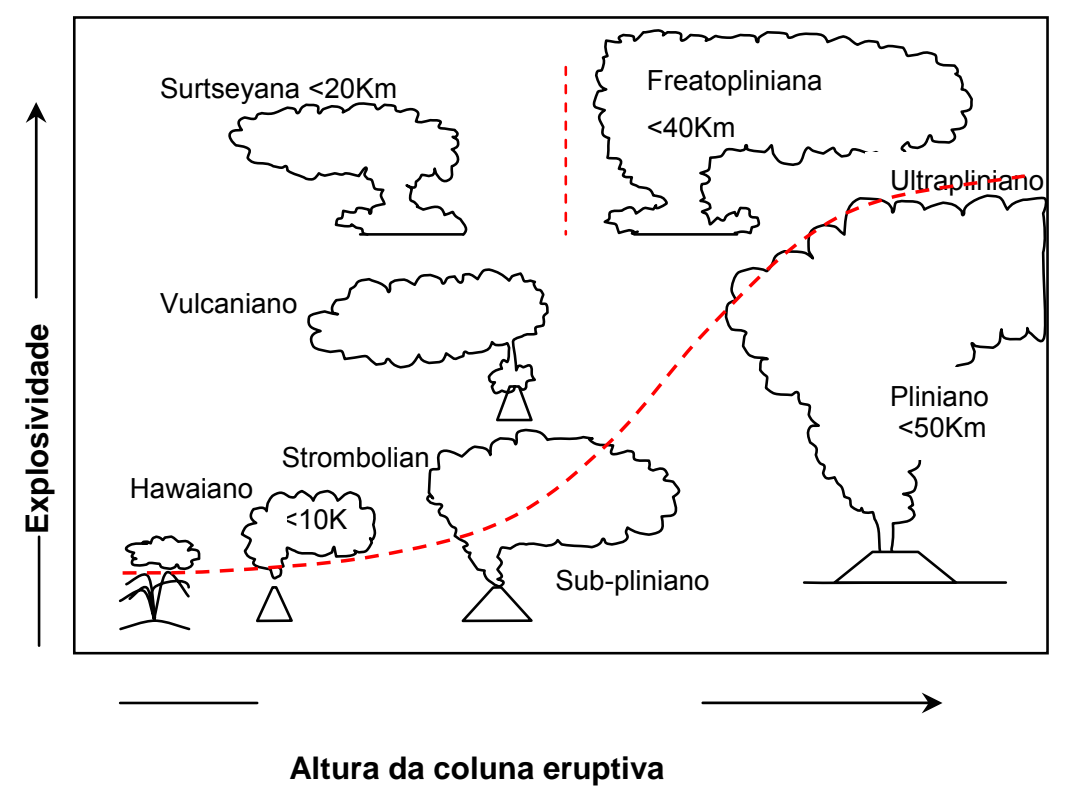

Classificação dos tipos de erupção a partir da explosividade, e os tipos de plumas geradas, segundo Cas \& Wright (1987)

Púmices: são fragmentos comuns em erupções explosivas magmáticas e estão relacionados com magmas altamente vesiculados. Apresentam geralmente cores claras e uma baixa densidade $\left(\leq 1 \mathrm{gcm}^{-3}\right)$ associada a uma alta vesicularidade, podendo conter cristais quando originados por magmas porfiríticos.

Queda piroclástica: Chuva de fragmentos piroclásticos caídos da atmosfera, que foram ejetados por plumas ou jatos eruptivos durante uma explosão vulcânica.

Reomorfismo: fluidez secundária gerada durante a fase de soldamento do ignimbrito, no qual devido às altas temperaturas ainda se apresenta em estado plástico. Está evidenciado pela presença da textura eutaxítica e fiammes.

Soldamento: é o processo de coesão e deformação do material piroclástico depositado a altas temperaturas e com uma carga sobreposta (FREUNDT et al., 2000). 
Surge (corrente piroclástica): são correntes turbulentas, gasosas, úmidas, frias $\left(<100^{\circ} \mathrm{C}\right)$ e de trajetória radial-horizontal, geradas por explosões surtseyanas e freatomagmáticas A abundância de gases confere-lhes baixa concentração de partículas sólidas e maior fluidez que aos fluxos piroclásticos. Surges e fluxos piroclásticos podem aparecer associados nos mesmos depósitos (VALENTINE \& FISHER, 2000).

Surge (depósito): depósito gerado por correntes piroclásticas de surge. Sua espessura, quando constituída por um único evento, raramente ultrapassa $0,50 \mathrm{~m}$ próximo nas proximidades da boca eruptiva; e a presença de lapilli acrescionários e estruturas sedimentares (tais como: laminação paralela, marcas de ondas, estratificação cruzada e lentes de fluidificação) são suas principais características distintivas. Depósitos de surge podem ocorrer na base de depósitos ignimbríticos (VALENTINE \& FISHER, 2000).

Trap-door collapse: Modelo de subsidência para caldeiras, baseado na geometria de subsidência e nas estruturas resultantes do colapso. Este tipo encontra-se delimitado por falhas marginais incompletas (em apenas um lado da caldeira) resultando assim no colapso parcial da caldeira (ver detalhes em LIPMAN, 2000).

Unidade de fluxo: Depósito constituído por apenas um único fluxo piroclástico (SPARKS,1976). Muitos ignimbritos são constituídos por mais de uma unidade de fluxo.

Unidade de Resfriamento Simples: depósito maciço, sem intercalações, constituído por uma única unidade de fluxo.

Unidade de Resfriamento Composta: depósito constituído por duas ou mais unidades fluxo que se resfriaram em conjunto. Isto ocorre quando os fluxos se depositam quase simultaneamente, evitando a perda de calor dos fluxos antecedentes. 


\section{$\underline{\text { Referências Bibliográficas }}$}

Cas, R.A.F., Wright, J.V., 1987. Volcanic Successions: Modern and Ancient. Chapman and Hall, London. 528p.

Freundt, A., Wilson, C.J.N., Carey, S.N., 2000. Ignimbrites and block-and-ash flow deposits. In: Sigurdsson, H., Houghton, B., McNutt, S.R., Rymer, H. e Stix, J. (Eds.): Encyclopedia of Volcanoes, p: 581-600. Academic Press.

Lipman, P.W., 2000. Calderas. In: Sigurdsson, H., Houghton, B., McNutt, S.R., Rymer, H. e Stix, J. (Eds.): Encyclopedia of Volcanoes, p: 643-662. Academic Press.

Lofgren, G., 1974. An experimental study of plagioclase crystal morphology: isothermal crystallisation. American Journal Science, 274, p: 243-273.

McPhie, J., Doyle, M, Allen, R., 1993. Volcanic Textures: A guide to the interpretation of textures in volcanic rocks. Centre for Ore Deposit and Exploration Studies. University of Tasmania, 198p.

Sparks, R.S.J., 1976. Grain size variation in ignimbrites and implications for the transport of pyroclastic flows. Sedimentology 23, p: 147-188

Valentine, G. A., Fisher, R. V., 2000. Pyroclastic Surges and Blasts. In: Sigurdsson, H., Houghton, B., McNutt, S.R., Rymer, H. e Stix, J. (Eds.): Encyclopedia of Volcanoes, p: 571-580. Academic Press.

Walker, G.P.L., 1983. Ignimbrite types and ignimbrite problems. Journal of Volcanology and Geothermal Research 17, p: 65-88.

Wilson, C.J.N., Houghton, B.F., 2000. Pyroclastic Transport and Deposition. In: Sigurdsson, H., Houghton, B., McNutt, S.R., Rymer, H. e Stix, J. (Eds.): Encyclopedia of Volcanoes, p: 545-554. Academic Press. 


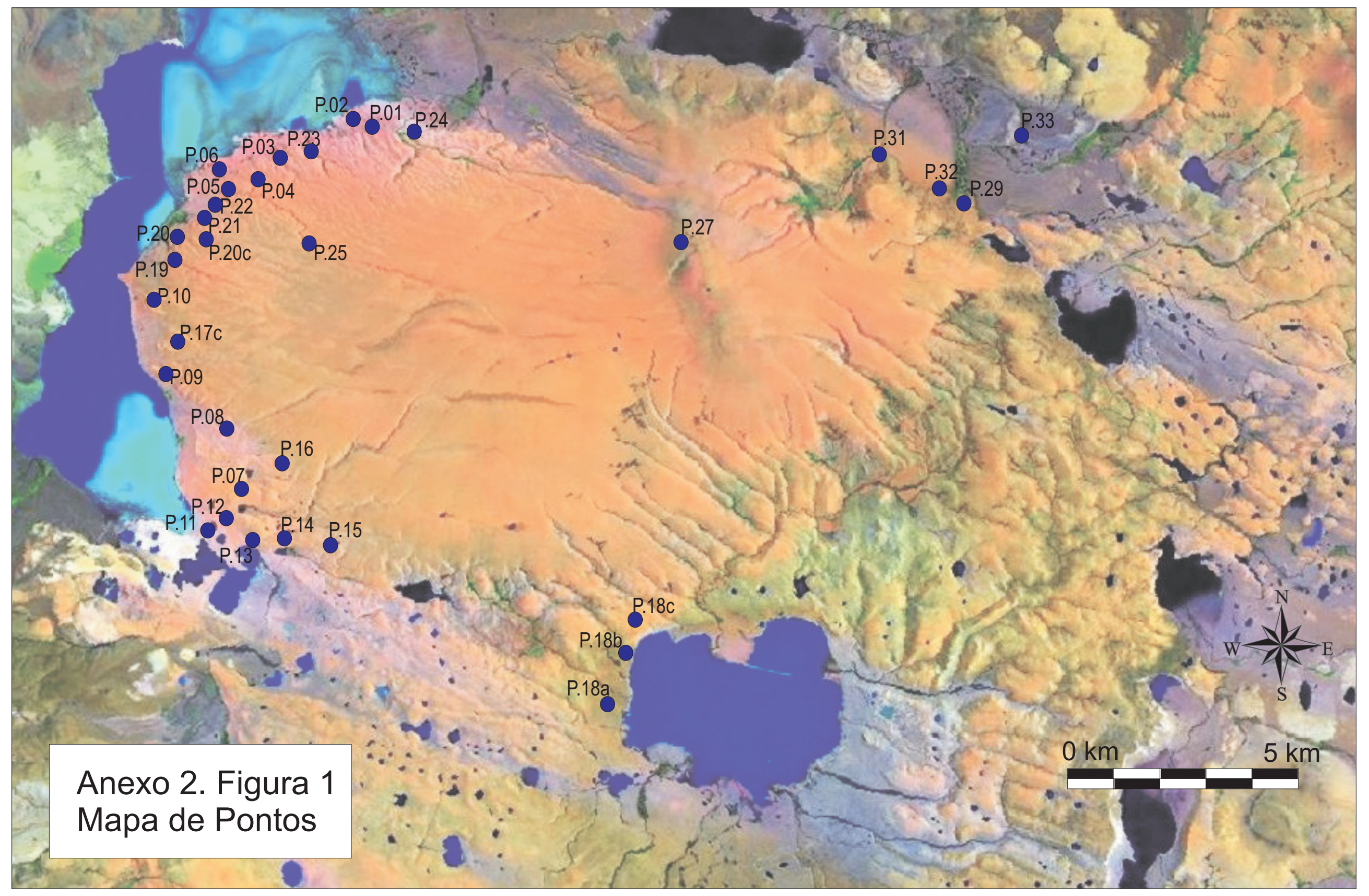




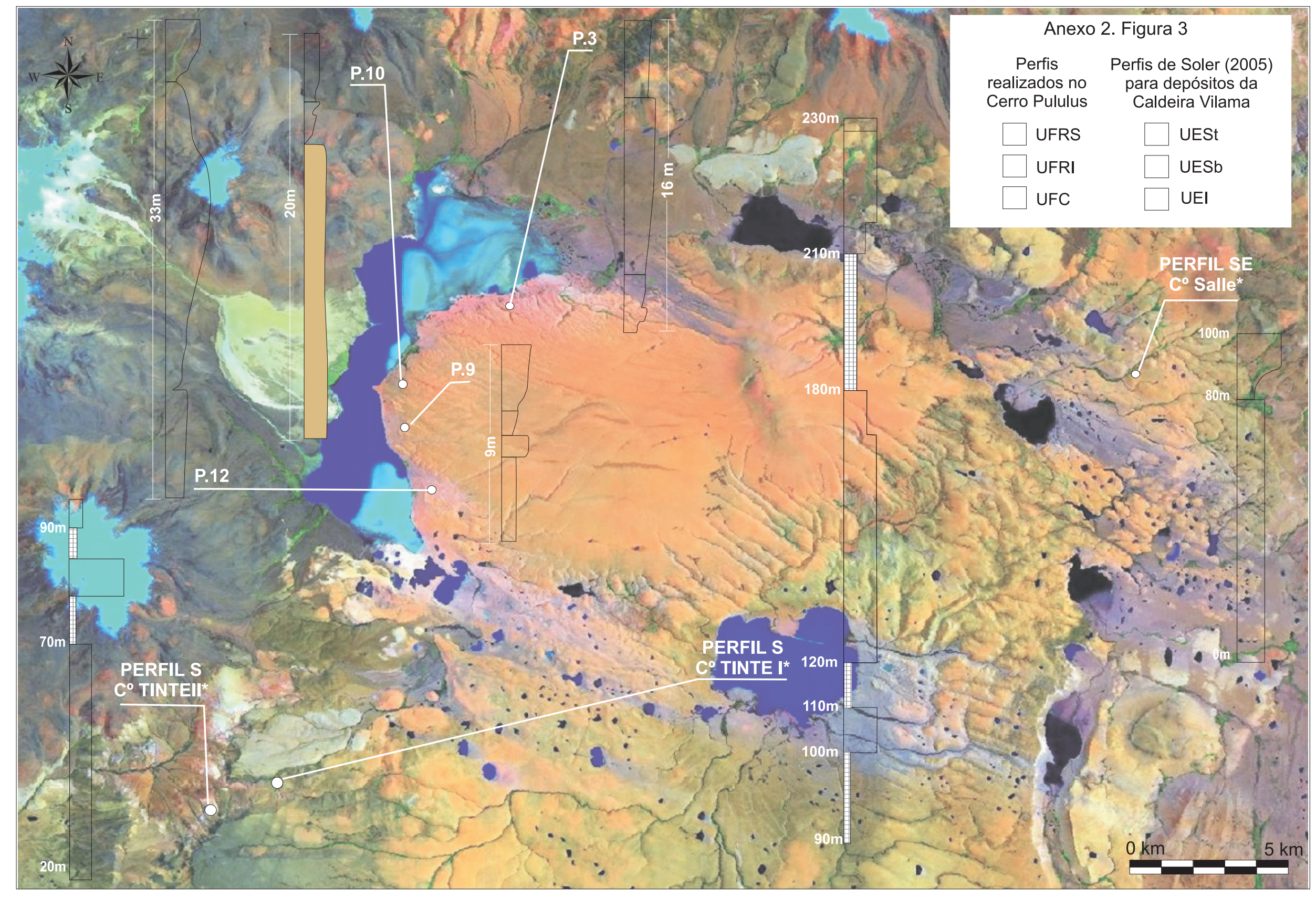




\begin{tabular}{|c|c|c|c|c|c|c|c|c|c|c|c|}
\hline PONTO & unidade & GPS & $\begin{array}{l}\text { ALTURA } \\
(\mathrm{msnm})\end{array}$ & $\begin{array}{l}\text { DESCRIÇÃO DO } \\
\text { AFLORAMENTO }\end{array}$ & espess. & amostras & $\%$ púmice & granul & $\%$ liticos & granul & $\begin{array}{l}\text { grau de } \\
\text { soldamento }\end{array}$ \\
\hline P01 & UFRI & $\begin{array}{l}22^{\circ} 34^{\prime} 24^{\prime \prime} / \\
66^{\circ} 51^{\prime} 50.7^{\prime \prime}\end{array}$ & 4524 & $\begin{array}{l}\text { Ignimbrito rosado com púmices } \\
\text { soldados em fiamme }\end{array}$ & $4 m$ & $\begin{array}{l}\text { PUL-01 (A, L, } \\
\text { V) } \\
\text { PUL-02 }\end{array}$ & & $<22 \mathrm{~cm}$ & & $<3 \mathrm{~cm}$ & 03:01 \\
\hline P02 & UFRI & $\mid \begin{array}{l}22^{\circ} 34^{\prime} \\
17.03^{\prime \prime} / \\
66^{\circ} 52^{\prime} 27.4 "\end{array}$ & 4513 & $\begin{array}{l}\text { Ignimbrito marrom-rosado, } \\
\text { soldado afetado por alteração } \\
\text { hidrotermal, com percolação de } \\
\text { óxidos }\end{array}$ & em planta & PUL-03 & & $<10 \mathrm{~cm}$ & & & 05:01 \\
\hline \multirow{3}{*}{$\begin{array}{l}\text { P03ia } \\
\text { P03ib } \\
\text { P03ic }\end{array}$} & \multirow{3}{*}{ UFRI } & \multirow{5}{*}{$\begin{array}{l}22^{\circ} 35^{\prime} 01.1^{\prime \prime} \\
\text { / 66055' } \\
02.4^{\prime \prime}\end{array}$} & \multirow{5}{*}{4522} & \multirow{5}{*}{$\begin{array}{l}\text { Ignimbrito marrom-rosado com } \\
\text { variações verticais, diferentes } \\
\text { graus de soldamento e } \\
\text { diaclases }\end{array}$} & $0,5 \mathrm{~m}$ & \multirow[t]{2}{*}{ PUL-04 } & $10-15 \%$ & $2-11 \mathrm{~cm}$ & $<5 \%$ & $3-14 \mathrm{~cm}$ & 2,5:01 \\
\hline & & & & & $1,5 \mathrm{~m}$ & & $25-35 \%$ & $2-15 \mathrm{~cm}$ & $<3 \%$ & $<5 \mathrm{~cm}$ & 02:01 \\
\hline & & & & & $0,8 \mathrm{~m}$ & PUL-05 & $25-30 \%$ & $2-15 \mathrm{~cm}$ & $<2 \%$ & $<5 \mathrm{~cm}$ & 02:01 \\
\hline \multirow{2}{*}{$\begin{array}{l}\text { P03sa } \\
\text { P03sb }\end{array}$} & \multirow{2}{*}{ UFRS } & & & & $13 m$ & PUL-07 & $25-30 \%$ & $2-30 \mathrm{~cm}$ & $<2 \%$ & $2-5 \mathrm{~cm}$ & 04:01 \\
\hline & & & & & $4 m$ & PUL-06 & $25-30 \%$ & $<25 \mathrm{~cm}$ & $<2 \%$ & $<3 \mathrm{~cm}$ & $3,5: 01$ \\
\hline \multirow[b]{2}{*}{ P04 } & \multirow{2}{*}{ UFRS } & \multirow{2}{*}{$\mid \begin{array}{l}22^{\circ} 35^{\prime} 17.7^{\prime \prime} \\
/ 66^{\circ} 53^{\prime} \\
31.3^{\prime \prime}\end{array}$} & \multirow{2}{*}{4590} & \multirow{2}{*}{$\begin{array}{l}\text { Ignimbrito marrom-rosado com } \\
\text { menor soldamento e púmice de } \\
\text { maior tamanho }\end{array}$} & \multirow[b]{2}{*}{$6 m$} & PUL-08 & \multirow[b]{2}{*}{$20-25 \%$} & \multirow[b]{2}{*}{$<25 \mathrm{~cm}$} & \multirow[b]{2}{*}{$<2 \%$} & & \multirow[b]{2}{*}{ 02:01 } \\
\hline & & & & & & PUL-09 & & & & & \\
\hline \multirow{2}{*}{$\begin{array}{l}\text { P05a } \\
\text { P05b }\end{array}$} & \multirow[b]{2}{*}{ UFRI } & \multirow{2}{*}{$\mid \begin{array}{l}22^{\circ} 35^{\prime} 13.3^{\prime \prime} \\
/ 66^{\circ} 53^{\prime} \\
43.1^{\prime \prime}\end{array}$} & \multirow{2}{*}{4565} & \multirow{2}{*}{$\begin{array}{l}\text { Ignimbrito rosado com variação } \\
\text { vertical no tamanho do púmice e } \\
\text { no grau de soldamento }\end{array}$} & $4 m$ & PUL-10 & $15-18 \%$ & $<25 \mathrm{~cm}$ & $2-3 \%$ & $0,5-5 \mathrm{~cm}$ & 4,3:01 \\
\hline & & & & & $2 m$ & PUL-11 & $10-12 \%$ & $4-15 \mathrm{~cm}$ & $2-3 \%$ & $<6,5 \mathrm{~cm}$ & 2,1:01 \\
\hline \multirow{2}{*}{ P06 } & \multirow{2}{*}{ UFRI } & \multirow{2}{*}{\begin{tabular}{|l|}
$22^{\circ} 35^{\prime} 17.0^{\prime \prime}$ \\
$/ 66^{\circ} 54^{\prime}$ \\
$10.7^{\prime \prime}$
\end{tabular}} & \multirow{2}{*}{4540} & \multirow{2}{*}{$\begin{array}{l}\text { veta Yareta em ignimbrito } \\
\text { rosado como rocha encaixante }\end{array}$} & \multirow{2}{*}{$10 \mathrm{~m}$} & PUL-12 & & & & & \\
\hline & & & & & & PUL-13 & & & & & \\
\hline \multirow{3}{*}{ P07 } & UFRS & \multirow{3}{*}{$\mid \begin{array}{l}22^{\circ} 39^{\prime} 28.9^{\prime \prime} \\
/ 66^{\circ} 53^{\prime} \\
38.7^{\prime \prime}\end{array}$} & \multirow{3}{*}{4534} & \multirow{3}{*}{$\begin{array}{l}\text { Contato de ignimbrito cinza não } \\
\text { soldado abaixo de ignimbrito } \\
\text { rosado lajoso }\end{array}$} & $3 m$ & PUL-14 & $8-10 \%$ & $<15 \mathrm{~cm}$ & $<2 \%$ & $<6 \mathrm{~cm}$ & 02:01 \\
\hline & UIFC & & & & \multirow{2}{*}{$2 m$} & PUL-15 & $12-15 \%$ & $1-15 \mathrm{~cm}$ & 5-8\% & $<5 \mathrm{~cm}$ & $\tilde{\tilde{n}}$ \\
\hline & & & & & & PUL-15P & base) & & & & \\
\hline & UFRS & $22^{\circ} 39^{\prime} 02.6^{\prime \prime}$ & & Contato de ignimbrito rosado & $<1,5 \mathrm{~m}$ & PUL-17 & $25-30 \%$ & $7-30 \mathrm{~cm}$ & $<2 \%$ & $<3 \mathrm{~cm}$ & 03:01 \\
\hline & UFC & $03.7^{\prime \prime}$ & & não soldado & $<1 \mathrm{~m}$ & PUL-16 & $15-20 \%$ & $1-12 \mathrm{~cm}$ & $<8 \%$ & $2-6 \mathrm{~cm}$ & $\tilde{n}$ \\
\hline
\end{tabular}




\begin{tabular}{|c|c|c|c|c|c|c|c|c|c|c|c|}
\hline PONTO & unidade & GPS & $\begin{array}{l}\text { ALTURA } \\
\text { (msnm) }\end{array}$ & $\begin{array}{l}\text { DESCRIÇÃO DO } \\
\text { AFLORAMENTO }\end{array}$ & espess. & amostras & \% púmice & granul & $\%$ liticos & granul & $\begin{array}{l}\text { grau de } \\
\text { soldamento }\end{array}$ \\
\hline P09a & \multirow{3}{*}{ UFC } & \multirow{5}{*}{$\begin{array}{l}22^{\circ} 38^{\prime} 21.8^{\prime \prime} \\
/ 66^{\circ} 54^{\prime} \\
29.8^{\prime \prime}\end{array}$} & \multirow{5}{*}{4544} & \multirow{5}{*}{$\begin{array}{l}\text { Contato de ignimbrito rosado } \\
\text { lajoso sobre ignimbrito cinza } \\
\text { não soldado }\end{array}$} & $3,5 \mathrm{~m}$ & PUL-18 & $15-18 \%$ & $4-15 \mathrm{~cm}$ & $<8 \%$ & $1,5-10 \mathrm{~cm}$ & 02:01 \\
\hline P09b & & & & & $0,8 \mathrm{~m}$ & PUL-19 & $23-25 \%$ & $4-25 \mathrm{~cm}$ & $8-12 \%$ & $1-5,5 \mathrm{~cm}$ & 5,1:01 \\
\hline P09c & & & & & $0,9 m$ & PUL-20 & $14-16 \%$ & $<15 \mathrm{~cm}$ & $<5 \%$ & $<10 \mathrm{~cm}$ & 02:01 \\
\hline P09d & \multirow{2}{*}{ UFRS } & & & & \multirow{2}{*}{$3 m$} & PUL-21 & \multirow{2}{*}{$15 \%$} & \multirow{2}{*}{$<20 \mathrm{~cm}$} & \multirow{2}{*}{$<2 \%$} & \multirow{2}{*}{$<10 \mathrm{~cm}$} & \multirow{2}{*}{$?$} \\
\hline P09e & & & & & & PUL-22 & & & & & \\
\hline P10a & \multirow[t]{2}{*}{ UFC } & \multirow{4}{*}{$\begin{array}{l}22^{\circ} 37^{\prime} 23.6^{\prime \prime} \\
/ 66^{\circ} 55^{\prime} \\
06.3^{\prime \prime}\end{array}$} & \multirow{4}{*}{4525} & \multirow{4}{*}{$\begin{array}{l}\text { Ignimbrito cinza lajoso } \\
\text { silicificado na porção mais } \\
\text { central e por vezes soldado com } \\
\text { algumas variações verticais, } \\
\text { muito rico em púmices e liticos } \\
\text { (17 metros de espessura) }\end{array}$} & $9 m$ & PUL-23 & \multirow[t]{2}{*}{$>40 \%$} & \multirow[t]{2}{*}{$1-30 \mathrm{~cm}$} & \multirow[t]{2}{*}{$5 \%$} & \multirow[t]{2}{*}{$<4 \mathrm{~cm}$} & \multirow[t]{2}{*}{$6,2: 1$} \\
\hline P10b & & & & & $5 m$ & PUL-24 & & & & & \\
\hline P10c & \multirow{2}{*}{ UFRS } & & & & $<2 \mathrm{~m}$ & PUL-25 & \multirow[t]{2}{*}{$30-35 \%$} & $1-8 \mathrm{~cm}$ & $<5 \%$ & $<1 \mathrm{~cm}$ & $?$ \\
\hline P10d & & & & & $<4 m$ & PUL-26 & & $1-15 \mathrm{~cm}$ & $<5 \%$ & $<4 \mathrm{~cm}$ & $?$ \\
\hline P11 & $?$ & $\begin{array}{l}22^{\circ} 39^{\prime} 42.0^{\prime \prime} \\
/ 66^{\circ} 54^{\prime} \\
58.5^{\prime \prime}\end{array}$ & 4528 & $\begin{array}{l}\text { Ignimbrito creme-rosado de } \\
\text { composição riolitica e aspecto } \\
\text { maciço }\end{array}$ & $10-15 m$ & PUL-27 & $15-18 \%$ & $1-3 \mathrm{~cm}$ & $2-3 \%$ & $1-10 \mathrm{~cm}$ & $\tilde{n}$ \\
\hline \multirow[b]{2}{*}{ P12 } & UFRS & \multirow{2}{*}{$\begin{array}{l}22^{\circ} 39^{\prime} 28.9^{\prime \prime} \\
/ 66^{\circ} 53^{\prime} \\
38.7^{\prime \prime}\end{array}$} & \multirow{2}{*}{4534} & \multirow{2}{*}{$\begin{array}{l}\text { Contato de ignimbrito lajoso } \\
\text { marrom-rosado }(3 \mathrm{~m}) \text { sobre } \\
\text { ignimbrito cinza }(30 \mathrm{~m}) \text { com } \\
\text { púmices elipsoidais, porém sem } \\
\text { soldamento }\end{array}$} & $3 m$ & PUL-14L & 8-10\% & $<15 \mathrm{~cm}$ & $<2 \%$ & $2-6 \mathrm{~cm}$ & 02:01 \\
\hline & UFC & & & & $30 \mathrm{~m}$ & \begin{tabular}{|l} 
PUL-15Ps \\
PUL-15Pi
\end{tabular} & $12-20 \%$ & $1-30 \mathrm{~cm}$ & $2-5 \%$ & $<25 \mathrm{~cm}$ & $\tilde{n}$ \\
\hline P13 & UFRS & $\begin{array}{l}22^{\circ} 39^{\prime} 35.5^{\prime \prime} \\
/ 66^{\circ} 54^{\prime} \\
18.4^{\prime \prime}\end{array}$ & 4530 & $\begin{array}{l}\text { Ignimbrito marrom-rosado } \\
\text { alterado com púmices soldados } \\
\text { em fiamme }\end{array}$ & $5 m$ & PUL-28 & $15-20 \%$ & $2-25 \mathrm{~cm}$ & $2-5 \%$ & $?$ & 3,9:01 \\
\hline P14 & UFRS & $\begin{array}{l}22^{\circ} 39^{\prime} 47.6^{\prime \prime} \\
/ 66^{\circ} 53^{\prime} \\
03.7^{\prime \prime}\end{array}$ & 4568 & $\begin{array}{l}\text { Ignimbrito rosado alterado com } \\
\text { menor \% de púmices e de } \\
\text { menor tamanho }\end{array}$ & & & $13-15 \%$ & $<10 \mathrm{~cm}$ & $<2 \%$ & $?$ & 04:01 \\
\hline P15 & UFRS & $\begin{array}{l}22^{\circ} 39^{\prime} 50.3^{\prime \prime} \\
/ 66^{\circ} 52^{\prime} \\
43.5^{\prime \prime}\end{array}$ & 4600 & $\begin{array}{l}\text { Ignimbrito rosado lajoso com } \\
\text { púmices em fiamme }\end{array}$ & & PUL-29 & $15-20 \%$ & $3-25 \mathrm{~cm}$ & $<2 \%$ & $1-3 \mathrm{~cm}$ & $4,6: 1$ \\
\hline
\end{tabular}




\begin{tabular}{|c|c|c|c|c|c|c|c|c|c|c|c|}
\hline PONTO & unidade & GPS & $\begin{array}{l}\text { ALTURA } \\
\text { (msnm) }\end{array}$ & $\begin{array}{l}\text { DESCRIÇÃO DO } \\
\text { AFLORAMENTO }\end{array}$ & espess. & amostras & $\%$ púmice & granul & $\%$ liticos & granul & $\begin{array}{l}\text { grau de } \\
\text { soldamento }\end{array}$ \\
\hline $\begin{array}{l}\text { P16 } \\
\text { (controle) }\end{array}$ & $\begin{array}{l}\text { UFRSI } \\
\text { UFRI/ } \\
\text { UFC }\end{array}$ & $\begin{array}{l}22^{\circ} 39^{\prime} 11.7^{\prime \prime} \\
/ 66^{\circ} 53^{\prime} \\
38.0^{\prime \prime}\end{array}$ & 4565 & $\begin{array}{l}\text { Contato de ignimbrito rosado } \\
\text { sobre ignimbrito cinza não } \\
\text { soldado. Aqui se observa uma } \\
\text { variação no soldamento da } \\
\text { unidade rosada e variação em } \\
\text { seu aspecto lajoso e } \\
\text { diaclasamento. Não é possivel } \\
\text { observar um contato nítido entre } \\
\text { UFRI e UFRS. }\end{array}$ & & & & & & & \\
\hline $\begin{array}{l}\text { P17 } \\
\text { (controle) }\end{array}$ & $\begin{array}{l}\text { UFRS/ } \\
\text { UFRI/ } \\
\text { UFC }\end{array}$ & $\begin{array}{l}22^{\circ} 37^{\prime} 41.1^{\prime \prime} \\
/ 66^{\circ} 54^{\prime} \\
29.6^{\prime \prime}\end{array}$ & 4600 & $\begin{array}{l}\text { Contato de ignimbrito marrom- } \\
\text { rosado lajoso sobre ignimbrito } \\
\text { cinza não soldado, com } \\
\text { espessura de aprox. } 50 \mathrm{~m} \text {. }\end{array}$ & $50 m$ & & & & & & \\
\hline P18a & UFC & $\begin{array}{l}22^{\circ} 40^{\prime} 54.7^{\prime \prime} \\
/ 66^{\circ} 48^{\prime} \\
58.4^{\prime \prime}\end{array}$ & 4464 & $\begin{array}{l}\text { Ignimbrito cinza em lajes } \\
\text { alterado para uma cor mais } \\
\text { vermelha na parte superior, com } \\
\text { fiammes }\end{array}$ & $6 \mathrm{~m}$ & PUL-32 & $15-20 \%$ & $2-30 \mathrm{~cm}$ & $<3 \%$ & $<3 \mathrm{~cm}$ & 09:01 \\
\hline P18b & UFRS & $\begin{array}{l}22^{\circ} 40^{\prime} 31.2^{\prime \prime} \\
/ 66^{\circ} 48^{\prime} \\
54.1^{\prime \prime}\end{array}$ & 4505 & $\begin{array}{l}\text { Mesmo ignimbrito (espessura } \\
\text { de } 100 \mathrm{~m} \text { ) porém com púmices } \\
\text { menores, em fiamme e } \\
\text { presença de pouquissimos } \\
\text { liticos }\end{array}$ & $70 m$ & \begin{tabular}{|l|} 
PUL-30 \\
PUL-30P
\end{tabular} & $15-20 \%$ & $<10 \mathrm{~cm}$ & $<1 \%$ & $<3 \mathrm{~cm}$ & 09:01 \\
\hline P18c & UFRS & $\begin{array}{l}22^{\circ} 40^{\prime} 17.9^{\prime \prime} \\
/ 66^{\circ} 48^{\prime} \\
51.0^{\prime \prime}\end{array}$ & 4550 & $\begin{array}{l}\text { Mesmo ignimbrito que } \\
\text { aparentemente cobre toda a } \\
\text { superficie sul do CoPululus, com } \\
\text { o mesmo aspecto rosado e } \\
\text { lajoso }\end{array}$ & $28 \mathrm{~m}$ & PUL-31 & $25-30 \%$ & $<10 \mathrm{~cm}$ & $<2 \%$ & $<3 \mathrm{~cm}$ & 8,6:01 \\
\hline P19 & $\begin{array}{l}\text { INTERME } \\
\text { D FÁCIES } \\
\text { la }\end{array}$ & $\begin{array}{l}22^{\circ} 36^{\prime} 40.1^{\prime \prime} \\
/ 66^{\circ} 55^{\prime} \\
07.1^{\prime \prime}\end{array}$ & 4530 & $\begin{array}{l}\text { Ignimbrito branco-creme, de } \\
\text { aprox } 10 \mathrm{~m} \text { de espessor }\end{array}$ & $10 m$ & \begin{tabular}{|l} 
PUL-33 \\
PUL-..................
\end{tabular} & $25-30 \%$ & $4-23 \mathrm{~cm}$ & $8-10 \%$ & $<22 \mathrm{~cm}$ & 4,5:01 \\
\hline P20 & UFRI & $\begin{array}{l}22^{\circ} 36^{\prime} 28.5^{\prime \prime} \\
/ 66^{\circ} 55^{\prime} \\
05.1^{\prime \prime}\end{array}$ & 4550 & $\begin{array}{l}\text { Contato de ignimbrito rosado } \\
\text { lajoso. Não se observa o } \\
\text { contato com ignimbrito P19 }\end{array}$ & $15 m$ & \begin{tabular}{|l} 
P20 \\
PUL-34
\end{tabular} & $20-25 \%$ & $2-25 \mathrm{~cm}$ & $<2 \%$ & $<5 \mathrm{~cm}$ & 5,2:01 \\
\hline
\end{tabular}




\begin{tabular}{|c|c|c|c|c|c|c|c|c|c|c|c|}
\hline PONTO & unidade & GPS & $\begin{array}{l}\text { ALTURA } \\
\text { (msnm) }\end{array}$ & $\begin{array}{l}\text { DESCRIÇÃO DO } \\
\text { AFLORAMENTO }\end{array}$ & espess. & amostras & $\%$ púmice & granul & $\%$ liticos & granul & $\begin{array}{l}\text { grau de } \\
\text { soldamento }\end{array}$ \\
\hline $\begin{array}{l}\text { P20b } \\
\text { (controle) }\end{array}$ & UFRI & $\begin{array}{l}22^{\circ} 36^{\prime} 08.6^{\prime \prime} \\
/ 66^{\circ} 54^{\prime} \\
52.7^{\prime \prime}\end{array}$ & 4530 & $\begin{array}{l}\text { Mesmo ignimbrito marrom- } \\
\text { rosado lajoso ( } 5 \mathrm{~m} \text { de espessor) } \\
\text { do P20 }\end{array}$ & $5 m$ & PUL-35 & $20-25 \%$ & $4-20 \mathrm{~cm}$ & $<2 \%$ & $<3 \mathrm{~cm}$ & 06:01 \\
\hline $\begin{array}{l}\text { P20c } \\
\text { (control) }\end{array}$ & UFRI & & & $\begin{array}{l}\text { Mesmo ignimbrito com aumento } \\
\text { de espessor para } 15 \mathrm{~m}\end{array}$ & $15 \mathrm{~m}$ & & & & & & \\
\hline P21 & UFRI & $\begin{array}{l}22^{\circ} 35^{\prime} 56.4^{\prime \prime} \\
/ 66^{\circ} 54^{\prime} \\
49.0^{\prime \prime}\end{array}$ & 4530 & $\begin{array}{l}\text { Ignimbrito marrom-rosado } \\
\text { lajoso, com púmices em } \\
\text { fiammes. Espessura de } 20 \mathrm{~m} \mathrm{e} \\
\text { aspecto maciço }\end{array}$ & $>20 m$ & & $25-30 \%$ & $2-31 \mathrm{~cm}$ & $2-5 \%$ & $<7 \mathrm{~cm}$ & 3,9:01 \\
\hline P22 & UFRI & $\begin{array}{l}22^{\circ} 35^{\prime} 45.4^{\prime \prime} \\
/ 66^{\circ} 54^{\prime} \\
25.5^{\prime \prime}\end{array}$ & 4590 & $\begin{array}{l}\text { Ignimbrito marrom-rosado lajoso } \\
\text { que aumenta de espessura e } \\
\text { passa a ser predominante no } \mathrm{C}^{\circ}\end{array}$ & $40 m$ & PUL-36 & $\begin{array}{l}28-30 \% \text { sup } \\
35-40 \% \text { inf }\end{array}$ & $3-50 \mathrm{~cm}$ & $2-5 \%$ & $<5 \mathrm{~cm}$ & 5,5:01 \\
\hline P23 & UFRI & $\begin{array}{l}22^{\circ} 34^{\prime} 48.5^{\prime \prime} \\
/ 66^{\circ} 53^{\prime} \\
21.6^{\prime \prime}\end{array}$ & 4550 & $\begin{array}{l}\text { Ignimbrito marrom-rosado e } \\
\text { aspecto maciço, com 30m de } \\
\text { espessura }\end{array}$ & $30 \mathrm{~m}$ & \begin{tabular}{|l|} 
PUL-37 \\
PUL-37L
\end{tabular} & $30-35 \%$ & $4-47 \mathrm{~cm}$ & $3-5 \%$ & $<40 \mathrm{~cm}$ & 4,6:01 \\
\hline P24 & UFRI & $\begin{array}{l}22^{\circ} 34^{\prime} 24.0^{\prime \prime} \\
/ 66^{\circ} 51^{\prime} \\
50.7^{\prime \prime}\end{array}$ & 4524 & $\begin{array}{l}\text { Ignimbrito rosado, soldado e em } \\
\text { fiamme }\end{array}$ & $40 m$ & \begin{tabular}{|l|} 
PUL-38 \\
PUL-38a
\end{tabular} & $30-40 \%$ & $<40 \mathrm{~cm}$ & $\begin{array}{l}3-5 \% \\
\text { (nível com } \\
5-8 \%)\end{array}$ & $\begin{array}{l}1-25 \mathrm{~cm} \\
\text { (até de } 50 \\
\text { e } 80 \mathrm{~cm})\end{array}$ & $4,5: 01$ \\
\hline P25 & UFRI & $\begin{array}{l}22^{\circ} 35^{\prime} 51.4^{\prime \prime} \\
/ 66^{\circ} 53^{\prime} \\
04.8^{\prime \prime}\end{array}$ & 4660 & $\begin{array}{l}\text { Antiga mina abandonda de } \\
\text { rocha ignimbritica soldada de } \\
\text { coloração rosada coberta por } \\
\text { uma pelicula de óxido (vermelha } \\
\text { e preta) }\end{array}$ & & PUL-ponto25 & & & & & \\
\hline P26 & INF ???? & $\begin{array}{l}22^{\circ} 35^{\prime} 51.4^{\prime \prime} \\
/ 66^{\circ} 53^{\prime} \\
04.8^{\prime \prime}\end{array}$ & 4660 & $\begin{array}{l}\text { Ignimbrito rosado soldado lajoso } \\
\text { que cobre o } \mathrm{C}^{\circ} \text { Pululus }\end{array}$ & $25 m$ & & $30-40 \%$ & $<22 \mathrm{~cm}$ & $<2 \%$ & $<3 \mathrm{~cm}$ & 3,9:01 \\
\hline P27 & UFRS & $22^{\circ} 35^{\prime} 55.9^{\prime \prime}$ & & $\begin{array}{l}\text { Mesmo ignimbrito marrom- } \\
\text { rosado no domo de Pululus, } \\
\text { porém mais fresco. }\end{array}$ & & & & & & & \\
\hline P28 & UFRS & $\mid \begin{array}{l}/ 66^{\circ} 48^{\prime} \\
23.0^{\prime \prime}\end{array}$ & 5100 & $\begin{array}{l}\text { Mesmo ignimbrito marrom- } \\
\text { rosado no domo de Pululus, } \\
\text { lajoso com púmices em fiamme }\end{array}$ & & PUL-44 & & & & & \\
\hline
\end{tabular}




\begin{tabular}{|c|c|c|c|c|c|c|c|c|c|c|c|}
\hline PONTO & unidade & GPS & $\begin{array}{l}\text { ALTURA } \\
\text { (msnm) }\end{array}$ & \begin{tabular}{|l|} 
DESCRIÇÃO DO \\
AFLORAMENTO
\end{tabular} & espess. & amostras & $\%$ púmice & granul & $\%$ liticos & granul & \begin{tabular}{|l} 
grau de \\
soldamento
\end{tabular} \\
\hline P29 & SUP ??? & \begin{tabular}{|l|}
$22^{\circ} 35^{\prime} 30.0^{\prime \prime}$ \\
$/ 66^{\circ} 44^{\prime}$ \\
$53.0^{\prime \prime}$
\end{tabular} & 4550 & $\begin{array}{l}\text { Ignimbrito marrom-rosado com } \\
\text { púmices em fiamme e mesmos } \\
\text { liticos }\end{array}$ & $3 m$ & PUL-39 & $30-40 \%$ & $3-12 \mathrm{~cm}$ & $<2 \%$ & $<3 \mathrm{~cm}$ & 5,5:01 \\
\hline P30 & SUP ??? & & & $\begin{array}{l}\text { Ignimbrito bem rosado com } \\
\text { púmices, afetado por alteração } \\
\text { hidrotermal, no qual } \\
\text { desprendem-se em bolas (ao } \\
\text { invés de placas) de alguns } \\
\text { pocos cm a até } 30 \mathrm{~m} \text { de } \\
\text { diâmetro }\end{array}$ & $10 \mathrm{~m}$ & & $30-40 \%$ & $3-15 \mathrm{~cm}$ & $<2 \%$ & $<3 \mathrm{~cm}$ & 05:01 \\
\hline P31 & SUP ??? & & & $\begin{array}{l}\text { Ignimbrito com púmices maiores } \\
\text { e maior grau de soldamento. O } \\
\text { afloramento apresenta } \\
\text { diaclasamento vertical e parece } \\
\text { estar bem silicificado }\end{array}$ & $60 \mathrm{~m} ?$ & \begin{tabular}{|l} 
PUL-40 \\
PUL-41
\end{tabular} & $30-40 \%$ & $3-15 \mathrm{~cm}$ & $<2 \%$ & $<3 \mathrm{~cm}$ & 7,1:01 \\
\hline $\begin{array}{l}\text { P32 } \\
\text { (observ) }\end{array}$ & SUP ??? & $\begin{array}{l}22^{\circ} 35^{\prime} 18.5^{\prime \prime} \\
/ 66^{\circ} 45^{\prime} \\
18.7^{\prime \prime}\end{array}$ & 4265 & $\begin{array}{l}\text { Zona de alteração que afeta a } \\
\text { borda NE do Co. Nota-se um } \\
\text { alinhamento N80W desta } \\
\text { alteração, de acordo com o } \\
\text { diaclasamento mais marcante, } \\
\text { com aumento de espessura } \\
\text { para oeste. }\end{array}$ & & PUL-42 & & & & & \\
\hline P33 & SALLE & $\begin{array}{l}22^{\circ} 34^{\prime} 40.6^{\prime \prime} \\
/ 66^{\circ} 44^{\prime}\end{array}$ & 4552 & Ignimbrito Salle & $5 m$ & PUL-43 & $25-30 \%$ & $<7 \mathrm{~cm}$ & & & 06:01 \\
\hline
\end{tabular}




\title{
ANEXO IV \\ DESCRIÇÕES PETROGRÁFICAS
}

\begin{abstract}
PUL 04A
Ponto:03ia - UFRI

Matriz com lapilli-púmices soldados (estirados, com bordas difusas e terminações em chamas) que se diferenciam da matriz devido a sua tonalidade mais clara. A matriz apresenta textura eutaxítica e foi afetada por alteração fase-vapor (que também afetou alguns minerais). Fragmentos angulosos de shards podem ser identificados devido a desvitrificação tipo axiolítica e micro-poiquilítica, dispersos na matriz. A desvitrificação do tipo esferulítica ocorre principalmente nos fragmentos de púmice.
\end{abstract}

Quartzo: fragmentado com bordas embainhadas e parcialmente reabsorvido. Ocorre principalmente como fenocristais poiquilíticos englobando cristais de plg.

Plagioclásio: ocorre com zoneamento simples, irregular e/ou com inclusões. Os fenocristais são os mais fraturados e podem apresentar textura do tipo peneira. Ocorre intercrescido a bt e com inclusões de bt e opacos. Também pode formar glomérulos de pequenos cristais englobados por bt ou qtz poiquilítico.

Biotita: alterada, ocorre de três formas distintas. Como placas finas; como placas maiores e mais largas, intercrescidas ao plagioclásio e preservando melhor o seu núcleo; como cristais completamente oxidados, associados aos glomérulos de plg.

Outros máficos (opx, cpx e hbl): Na matriz estes minerais são raros e muitos foram reconhecidos como pseudomorfos. Já nos lapilli-púmices estes minerais são mais abundantes e estão mais preservados. Não foi identificada nenhuma hbl, tanto na matriz como nos púmices. Dentre os px, a enstatita é a mais abundante e ocorre como microfenocristais euédricos a sub-édricos. A augita também é rara e ocorre apenas nos púmices. Apenas um fenocristal de opx foi encontrado, apresentando espessas bordas de oxidação e núcleo ainda preservado.

Opacos: encontra-se disperso na matriz e nos púmices. Pode ocorrer como pequenas e finas placas (provável ilm) ou como fenocristais com bordas avermelhadas (provável mgn). Também está associado a um pequeno aglomerado de plg e bt.

Fragmento Lítico: rocha de provável origem sedimentar (do embasamento), composta por cristais arredondados e parcialmente recristalizados de qtz.

PUL 05A

Ponto:03ic - UFRI

Matriz vulcanoclástica rica em cristaloclastos e lapilli-púmices soldados. Os púmices apresentam as bordas pouco definidas e terminações em chama. A matriz apresenta uma textura eutaxítica e desvitrificação do tipo microgranofírica (i.e. glass-shards deformados e visíveis apenas pela desvitrificação). A textura esferulítica ocorre apenas nos púmices. A rocha está afetada por sericitização (que atravessa as bordas e fraturas dos minerais, como também os esferulítos de desvitrificação).

Bt: biotita; Cpx: clinopiroxênio; Hbl:hornblenda; Ilm: Ilmenita; Mgn: magnetita; Opx: ortopiroxênio; Plg: plagioclásio; Qtz: quartzo; 
Quartzo: fragmentado, com bordas embainhadas e parcialmente reabsorvido. Alguns cristais $(<2 \mathrm{~mm})$ ocorrem em forma de gota, indicando uma intensa reabsorção. Também ocorre como cristais poiquilíticos englobando cristais de plg.

Plagioclásio: Os cristais maiores $(<1,8 \mathrm{~mm})$ exibem marcante zoneamento, em geral irregular e com núcleo corroído (textura tipo peneira), além de uma grande quantidade de inclusões. Outros grandes fragmentos apresentam seu zoneamento truncado, com núcleo e zonas afetadas por corrosão. Também observam-se aglomerados de pequenos cristais de plg (limpos, sem zoneamento ou inclusões) associado a cristais de bt, \pm opx, \pm hbl.

Biotita: ocorre parcial ou totalmente alterada como cristais individuais ou associados a aglomerados de plg, \pm opx, \pm hbl. Os cristais maiores (individuais) podem estar intercrescidos ou manteados por plg. Em suas fraturas também se observam pequenas inclusões de zircão, porém sem formar halos pleocróicos.

Outros máficos (opx, cpx e hbl): cristais de opx e cpx apresentam espessas bordas de alteração ou estão completamente alterados. Muitos podem ser identificados apenas como pseudomorfos. Ambos ocorrem como cristais isolados, ou em grandes aglomerados de cpx+opx ou cpx+opx+plg+bt. Não foi encontrado $\mathrm{Hbl}$.

\section{PUL 06B}

Ponto:03sb - UFRI

Amostra de matriz com lapilli-púmices. A matriz apresenta textura eutaxítica, com glass-shards desvitrificados (textura microgranofírica) que se moldam em torno de cristaloclastos e púmices. Os púmices também estão desvitrificados, apresentando textura esferulítica caótica. Os minerais máficos apresentam-se bastante oxidados.

Quartzo: cristais fragmentados, embainhados ou com bordas arredondadas. Em alguns ainda é possível definir suas formas hexagonais. Fenocristais maiores $(<2 \mathrm{~mm})$ ocorrem como cristais poiquilíticos englobando aglomerados de pequenos cristais de plg e bt.

Plagioclásio: fragmentado ou fraturado, apresenta zoneamento irregular, com textura de dissolução acompanhando o zoneamento ou apenas com seu núcleo corroído (textura esponjosa). Pode ocorrer intercrescido a bt (formando aglomerados) ou como inclusão em minerais máficos.

Biotita: é o mineral máfico mais abundante, sempre muito alterado e oxidado. É encontrado em duas formas distintas: como grandes cristais com inclusões de plg (principalmente) e outros minerais acessórios e como placas completamente oxidadas associados aos glomérulos de plg.

Outros máficos (opx, cpx e hbl): São bastante raros na rocha. É provável que sua escassez se deva ao avançado grau de alteração que afeta a rocha o que dificulta a identificação de alguns máficos (prováveis pseudomorfos).

Opacos: ocorrem como cristais idiomórficos de bordas bem avermelhadas. Mineral não identificado, provável mgn. 
Amostra de matriz com lapilli-púmice. A matriz apresenta textura eutaxítica e cristalização fase-vapor formando lithophysaes estirados (paralelos ao estiramento dos púmices). Os púmices estão desvitrificados, com texturas do tipo esferulítica e "fan". Suas vesículas estão parcialmente preenchidas devido a cristalização fase-vapor que afetou a rocha. O soldamento é incipiente.

Quartzo: cristais fragmentados, embainhados ou com bordas arredondadas. Em alguns ainda é possível definir suas formas hexagonais. Fenocristais poiquilíticos $(<2 \mathrm{~mm}$ ) englobam aglomerados de pequenos cristais de plg e bt;

Plagioclásio: intactos, fragmentados ou fraturados. Apresentam zoneamento irregular, com texturas de dissolução acompanhando o zoneamento ou apenas com seu núcleo corroído (textura tipo peneira). Pode ocorrer intercrescido a bt e opacos (formando aglomerados) ou como inclusão em minerais máficos. Também pode apresentar inclusões de opx;

Biotita: muita alterada, cloritizada e/ou oxidada. Ocorre intercrescida ao plg e apresenta inclusões de outros minerais acessórios. Também se observam cristais de bt manteados por plg ou bordejados por diversos microcristais de plg. Pode ocorrer associada aos glomérulos de plg.

Outros máficos (opx, cpx e hbl): são minerais bem escassos na rocha, apresentando um avançado grau de oxidação;

Opacos: ilm e mgn (este último com bordas mais avermelhadas e euédrico). Comumente encontra-se um mineral não identificado, que, devido ao estado de oxidação dos máficos, interpreta-se como provável pseudomorfo, completamente substituídos por opacos.

PUL 08

Ponto: 04 - UFRS

Amostra de matriz com lapilli-púmices e fragmento lítico de rocha vulcânica (constituída por qtz, plg e máficos). A matriz ainda apresenta algumas feições de textura eutaxítica preservada. Os púmices aparentemente estão bem soldados, com bordas e terminações pouco definidas (difusas). A alteração fase-vapor que afetou a rocha não foi muito intensa (alguns plg estão sericitizados), sendo que a desvitrificação se mostra presente principalmente nos púmices, com uma textura do tipo microgranofírica nas porções centrais e esferulítica (parcial ou completa) em suas bordas.

Quartzo: cristais intensamente fraturados e/ou fragmentados, embainhados ou com bordas arredondadas. Em alguns ainda é possível definir suas formas hexagonais e outros ocorrem como "gotas", completamente arredondados. Fenocristais poiquilíticos $(<2 \mathrm{~mm})$, também de forma hexagonal, englobam pequenos cristais de plg e/ou bt, apresentando-se mais preservados no interior de púmices;

Plagioclásio: ocorrem fragmentados ou fraturados, principalmente os cristais maiores. Apresentam zoneamento irregular, com texturas de dissolução que acompanha o zoneamento ou apresentando apenas o seu núcleo corroído (textura tipo peneira).

Bt: biotita; Cpx: clinopiroxênio; Hbl:hornblenda; Ilm: Ilmenita; Mgn: magnetita; Opx: ortopiroxênio; Plg: plagioclásio; Qtz: quartzo; 
Podem apresentar concentrações de inclusões fluídas acompanhando a borda de algumas zonas ou pequenas inclusões fluídas e/ou micrólitos formando um desenho em espiral dentro do cristal. Suas bordas também podem apresentam-se angulosas e/ou corroídas e muitos se encontram intercrescidos com bt e opacos. Também se observam cristais de plagioclásio com zoneamento truncado e borda de sobrecrescimento;

Biotita: Apresenta-se bastante oxidada ou desagregando-se, devido talvez a alteração fase-vapor. Pode apresentar inclusões de plg ou estar intercrescida a este. Também ocorre associada aos glomérulos de plg.

Outros máficos (opx, cpx e hbl): A presença de hbl é esporádica. Os poucos cristais são de difícil distinção, apresentando grossas bordas de oxidação. O opx ocorre como pequenos cristais euédricos (maior que a hbl e cpx), apresentando grossas bordas de oxidação com apenas o núcleo preservado. A maioria representa cristais de enstatita. O cpx também apresenta grossas bordas de oxidação de coloração avermelhada e só é reconhecido devido ao seu núcleo que ainda está preservado. Alguns cristais foram reconhecidos como pseudomorfos.

Opacos: ocorrem como cristais euédricos avermelhados, provável mgn.

\section{PUL 10A}

Ponto:05a - UFRI

Amostra de matriz com lapilli-púmices. A matriz apresenta textura eutaxítica e os púmices estão desvitrificados com textura do tipo microgranofírica. O púmice é rico em minerais máficos (grandes fenocristais de bt, além de fenocristais de opx euédrico).

Quartzo: os cristais apresentam-se fragmentados, embainhados ou com bordas arredondadas. Em alguns ainda é possível definir suas formas hexagonais. Fenocristais poiquilíticos $(<2 \mathrm{~mm})$, também de forma hexagonal, englobam pequenos cristais de plg e/ou bt;

Plagioclásio: os cristais ocorrem mais fragmentados e/ou fraturados na matriz, sendo que cristais maiores são mais abundantes no púmice. Podem apresentar zoneamento irregular, com texturas de dissolução acompanhando o zoneamento ou apenas um núcleo corroído (textura tipo peneira). Também apresentam concentrações de inclusões fluídas acompanhando a borda de algumas zonas ou pequenas inclusões fluídas e/ou micrólitos formando um desenho em espiral dentro do cristal. Suas bordas também podem apresentam-se angulosas e/ou corroídas. Muitos estão intercrescidos com bt e opacos, ou apresentam sericitização nas bordas;

Biotita: Apresenta-se bastante oxidada ou desagregando-se, devido talvez a alteração fase-vapor. Muitos cristais apresentam inclusões de plg (principalmente nas bordas) ou estão intercrescidos a este. Também ocorre associada aos glomérulos de plg.

Outros máficos (opx, cpx e hbl): O opx é o segundo mineral máfico predominante na rocha. É comum sua associação com plg, no qual, opx ocorre com formas subédricas a xenomórficas dentro do plg, ou o plg cristaliza-se ao redor de fenocristais euédricos a subédricos de opx. Os microcristais podem ocorrer dispersos ou também associados aos discretos bandamentos dentro do púmice. Os fenocristais são mais susceptíveis em apresentar grossas bordas de oxidação. 
A hbl ocorre predominantemente como microcristais (euédricos a xenomórficos) associados a discretas concentrações de minerais máficos no púmice (semelhante a finos bandamentos). Os cristais individuais que ocorrem dispersos no púmice apresentam, em geral, grossas bordas de oxidação (de coloração avermelhada) com apenas seu núcleo preservado. Não foi encontrado na matriz.

O cpx ocorre disperso ou também associado ao bandamento dentro do púmice, junto ao opx e hbl. Pode apresentar formas euédricas a xenomórficas, com bordas oxidadas e núcleo preservado.

Opacos: ocorrem como minerais avermelhadas (provável mgn) ou como produtos de alteração de minerais máficos.

PUL 14

Ponto: 07a - UFRS

Amostra de matriz com lapilli-púmice. A matriz apresenta uma grande quantidade de cristais $(\approx 50 \%)$ e está afetada por alteração fase-vapor, o que pode ter mascarado a textura eutaxítica. Os púmices estão bem compactados e desvitrificados, apresentando textura do tipo microgranofírica.

Quartzo: os cristais estão fragmentados, parcialmente embainhados ou com bordas arredondadas. Em alguns ainda é possível definir suas formas hexagonais. Fenocristais poiquilíticos $(<1,4 \mathrm{~mm})$ englobam pequenos cristais de plg.

Plagioclásio: os cristais ocorrem fragmentados e/ou fraturados [principalmente os cristais maiores $(<1,8 \mathrm{~mm})]$. A grande maioria apresenta zoneamento irregular complexo e extinção ondulante. Outros cristais apresentam vestígios de exsolução ou dissolução, acompanhando o zoneamento ou apenas com seu núcleo corroído (textura do tipo peneira). Pode apresentar concentrações de inclusões fluídas acompanhando a borda de algumas zonas composicionais do cristal. Suas bordas podem estar angulosas e/ou corroídas. Muitos estão intercrescidos com bt e opacos.

Biotita: Apresenta-se um pouco oxidada. Muitos cristais apresentam inclusões de plg ou estão intercrescidos a este. Também apresenta inclusões de cpx, hbl e opacos.

Outros máficos (opx, cpx e hbl): 0 opx pode apresentar finas bordas de oxidação, como também arredondamento de suas bordas. Alguns cristais são ricos em inclusões (aparentemente inclusões fluídas). A hbl apresenta coloração esverdeada e uma alta birrefringência, assemelhando-se com o cpx. Pode apresentar bordas de oxidação e ocorrer como inclusão em cristais de bt. $\mathrm{O} \mathrm{cpx}$ ocorre fragmentado, porém, aparentemente está mais estável que outros máficos (opx e hbl).

Opacos: como produto de alteração de minerais máficos.

PUL 15PE

Ponto: 07b - UFC

\section{Descrição Macroscópica}

Púmice rico em cristais, de matriz afanítica e leucocrática (coloração rosa-clara acinzentada). Apresenta microfenocristais de minerais máficos (provavelmente bt) e 
vesículas preenchidas por minerais félsicos (provavelmente qtz e plg). Observa-se um suave bandamento pouco uniforme (cinza/rosa).

\section{Descrição Microscópica}

Amostra de lapilli-púmice com textura vitroclástica e de desvitrificação. Apresenta uma grande quantidade em cristais e poucas vesículas. Foi afetada por alteração fasevapor.

Quartzo: cristais fragmentados, parcialmente embainhados ou com bordas arredondadas. Em alguns ainda é possível definir suas formas hexagonais. Fenocristais poiquilíticos $(<1,4 \mathrm{~mm})$ englobam pequenos cristais de plg idiomórfico e bt. Também é freqüente a inclusão de micrólitos (plg?).

Plagioclásio: Os cristais estão fragmentados ou fraturados e muitos apresentam suas bordas sericitizadas, podendo ser angulosas e/ou corroídas. Pode apresentar zoneamento irregular complexo e extinção ondulante. Alguns poucos cristais apresentam vestígios de exsolução ou dissolução que acompanha o zoneamento ou apenas apresenta seu núcleo corroído (textura do tipo peneira). Concentrações de inclusões fluídas podem acompanhar a borda de algumas zonas composicionais do cristal. Cristais menores e limpos podem estar intercrescidos a bt e opacos e cristais maiores ocorrem nas bordas de vesículas ou formando glomérulos;

Biotita: Ocorre bastante oxidada. Apresenta inclusões de plg ou está intercrescida ao mesmo, dando a impressão que está se "desagregando". Também apresenta inclusões de px, qtz e opacos.

Outros máficos (opx, cpx e hbl): Os microfenocristais de opx apresentam finas bordas de oxidação e estão parcialmente arredondados. Pode apresentar inclusões de plg e opacos. A hbl é rara e ocorre como um minúsculo cristal sub-édricos (com pontas quebradas). Também apresenta suas bordas oxidadas. $\mathrm{O} c p x$ está fragmentado, e pode ocorrer como fenocristais maiores que o opx, porém em menor abundancia. Entre os máficos é o mais resistente à alteração.

Opacos e acessórios: opacos como produto de alteração de minerais máficos. Zircão e apatita como acessórios.

\section{PUL 16B}

Ponto: 08 - UFC

\section{Descrição macroscópica}

Matriz rica em cristaloclastos e púmices na fração lapilli-cinza. A matriz apresenta abundância em cristaloclastos de bt e minerais félsicos. Os fragmentos de púmice apresentam uma coloração rosada e tonalidade mais clara e são ricos em fenocristais (com granulometria maior que os cristais da matriz) de minerais máficos (provável bt) e minerais félsicos (qtz e plg). A amostra não está soldada e pode ter sido afetada por alteração ou cristalização fase-vapor.

\section{Descrição microscópica}

Amostra de ignimbrito desvitrificado e afetado, levemente, por compactação e cristalização fase-vapor. A matriz apresenta textura eutaxítica, parcialmente encoberta por sericitização, e shards pouco deformados que ainda podem ser reconhecidos 
devido à textura de desvitrificação (esferulítica na porção interna e axiolítica próximo as paredes). Lapilli-púmices menores estão aparentemente soldados, com bordas pouco definidas e terminações em chama; e também apresentam texturas de desvitrificação esferulítica e microgranofírica, além de perlítos e lithophysaes (ou talvez vesículas). O fragmento lítico representa uma rocha vulcânica de composição andesitica e textura micro-traquítica.

Quartzo: cristais idiomórficos (hexagonais) ou fragmentados, embainhados e/ou com bordas arredondadas. Alguns fenocristais poiquilíticos $(<1,4 \mathrm{~mm})$ englobam pequenos glomérulos de plg idiomórfico e também bt. É freqüente a inclusão de micrólitos de plg nos cristais maiores.

Plagioclásio: os cristais estão fragmentados ou fraturados e muitos apresentam suas bordas sericitizadas, angulosas e/ou corroídas. Pode apresentar zoneamento irregular complexo e extinção ondulante. Alguns poucos cristais apresentam vestígios de exsolução ou dissolução que acompanha o zoneamento ou apresenta apenas um núcleo corroído (textura esponjosa). Pode também apresentar concentrações de inclusões fluídas acompanhando a borda de algumas zonas composicionais do cristal. Muitos estão intercrescidos com bt e opacos e os cristais maiores ocorrem nas bordas de vesículas ou formando glomérulos.

Biotita: Ocorre bastante oxidada. Apresenta inclusões de plg ou está intercrescida ao mesmo, dando a impressão que está se "desagregando". Também apresenta inclusões de px, qtz e opacos.

Outros máficos (opx, cpx e hbl): O opx ocorre como microfenocristais euédricos a sub-édricos (levemente a intensamente fraturados) com finas bordas de oxidação e poucas inclusões. O cpx encontra-se fraturado e/ou fragmentado (assim como a hbl), porém, aparentemente está mais estável que outros máficos (opx e bt). Não foi encontrado hbl

Opacos e acessórios: opacos associados a glomérulos de bt e plg ou como produto de alteração de minerais máficos. Zircão e apatita como acessórios.

\section{PUL 18B}

Ponto: 09a - UFC

\section{Descrição Macroscópica}

Púmice vesículado, rico em fenocristais, com matriz afanítica e leucocrática de cor rosa-clara acinzentada. Fenocristais de minerais máficos (provavelmente bt oxidada) e vesículas preenchidas por minerais félsicos (provavelmente qtz e plg).

\section{Descrição microscópica}

Amostra de lapilli-púmice com textura vitroclástica e desvitrificação esferulítica. Apresenta uma grande quantidade de cristais (30-35\%), algumas vesículas e porções sericitizadas (que também afeta alguns cristais de plg) associada talvez à alteração fase-vapor.

Bt: biotita; Cpx: clinopiroxênio; Hbl:hornblenda; Ilm: IImenita; Mgn: magnetita; Opx: ortopiroxênio; Plg: plagioclásio; Qtz: quartzo; 
Quartzo: fenocristais fragmentados, bastante embainhados ou com bordas arredondadas. Também ocorre como cristais finais que englobam pequenos cristais de plg idiomórfico ou de bordas corroídas.

Plagioclásio: Os cristais estão fragmentados ou fraturados e muitos apresentam suas bordas e fraturas internas sericitizadas. Apresentam feições de dissolução, seguidos por recristalização e zoneamento. Alguns apresentam seu núcleo corroído (textura tipo peneira) e/ou apresentam zoneamento apenas em suas bordas. Muitos estão intercrescidos com bt e opacos e os cristais maiores ocorrem nas bordas de vesículas ou formando glomérulos.

Biotita: Ocorre como fenocristais com oxidação avançada. Apresenta inclusões de plg ou está intercrescida ao mesmo. Também apresenta inclusões de opx e opacos.

Outros máficos (opx, cpx e hbl): opx ocorre como feno e microcristais euédricos a subédricos (devido a dissolução parcial ou arredondamento de suas bordas). Também apresenta finas bordas de oxidação. Nos cortes paralelos ao eixo-c observa-se zonas de dissolução ou de crescimento concomitante com outros minerais (geralmente plg intercrescido). Cpx ocorre como pequenos grãos, podendo estar associado a cristais de opx. Seu grau de oxidação está bem menos avançado que em outros minerais máficos. A hbl apresenta bordas de oxidação ou está completamente oxidada com pequenas porções internas ainda preservadas;

Opacos e acessórios: opacos como produto de alteração de minerais máficos. Zircão e apatita como acessórios.

\section{PUL 19}

Ponto: 09b - UFC

\section{Descrição macroscópica}

Matriz leucocrática e afanítica, rica em cristaloclastos e presença de púmice $(<2,0 \mathrm{~mm})$ como fiammes brancos e rosados. Observa-se uma maior concentração de minerais máficos na matriz do que nos púmices. A matriz apresenta em maior abundância fenocristais de minerais máficos (bt oxidada) e os púmices apresentam pequenas vesículas preenchidas por minerais félsicos (qtz e plg).

\section{Descrição microscópica}

Matriz com textura eutaxítica e cristais bastante cominuidos. Os fiammes de púmice apresentam textura de desvitrificação do tipo esferulítica. Ocorre uma grande quantidade de cristais (30-35\%), algumas vesículas e também porções sericitizadas (que pode afetar alguns cristais de plag) associadas talvez à uma alteração fasevapor.

Quartzo: cristais arredondados e/ou engolfados (principalmente os cristais maiores) podendo, ou não, apresentar fraturas internamente. Poucos cristais ainda preservam suas bordas e arestas retas, evidenciando sua forma originalmente hexagonal. Pode ocorrer como cristais poiquilíticos ou como pequenos glomérulos de dois ou três cristais de quartzo;

Plagioclásio: cristais fragmentados ou fraturados, com bordas arredondadas. Apresentam feições de dissolução, seguidos por recristalização e zoneamento. Alguns apresentam seu núcleo corroído (textura tipo peneira) e/ou apresentam zoneamento 
apenas em suas bordas. Outros apresentam seu zoneamento truncado com recristalização posterior. Muitos estão intercrescidos com bt e opacos e os cristais maiores ocorrem nas bordas de vesículas ou formando glomérulos.

Biotita: ocorre oxidada e muitas vezes desagregada dentro do púmice, constituindo uma sombra que evidencia o soldamento e o reomorfismo sofridos pela rocha.

Outros máficos (opx, cpx e hbl): Opx está presente como pequenos cristais euédricos com finas bordas de oxidação. $O$ único fenocristal observado $(>0.8 \mathrm{~mm})$ apresenta inclusões de opx anterior e plg no seu interior, além de plg e bt em sua borda. O cpx está presente como cristais euédricos e subédricos e bordas oxidadas. Apresenta inclusões de outros minerais máficos (opx) e opacos.

Opacos e acessórios: opacos ocorrem apenas como material de alteração de minerais máficos. Acessórios estão dispersos pelo púmice e inclusos no plagioclásio.

\section{PUL 20C \\ Ponto: 09c - UFC}

\section{Descrição macroscópica}

Púmice elipsoidal e vesiculado, rico em fenocristais, com matriz leucocrática (de coloração rosa-clara acinzentada). Apresenta fenocristais de minerais máficos (provavelmente bt oxidada) e vesículas preenchidas por minerais félsicos (qtz e plg).

\section{Descrição microscópica}

Amostra de lapilli-púmice com textura vitroclástica e desvitrificação esferulítica. Apresenta uma grande quantidade de cristais (30-35\%), algumas vesículas e porções sericitizadas (que também afeta alguns cristais de plg) devido à alteração fase-vapor (mais intenso que na amostra PUL-18B/Pto.09a)

Quartzo: cristais fragmentados, bastante embainhados ou com bordas arredondadas. Ocorre principalmente como cristais poiquilíticos $(<3 \mathrm{~mm})$ que englobam pequenos cristais de plg idiomórfico (ou com bordas corroídas). Observaram-se inclusões anisótropas (semelhante a vidro).

Plagioclásio: Os cristais estão fragmentados ou fraturados e muitos apresentam suas bordas e fraturas internas sericitizadas. Apresentam feições de dissolução, seguidos por recristalização e zoneamento. Alguns apresentam seu núcleo corroído (textura esponjosa) e/ou concentrações de inclusões fluídas acompanhando a borda de algumas zonas composicionais do cristal. Suas bordas também podem apresentam-se angulosas e/ou corroídas. Muitos estão intercrescidos com bt e opacos e os cristais maiores ocorrem nas bordas de vesículas ou formando glomérulos;

Biotita: Ocorre bastante oxidada. Pode apresentar inclusões de plg, zircão e opacos.

Outros máficos (opx, cpx e hbl): opx ocorre como cristais euédricos ou grãos arredondados (devido à dissolução parcial de suas bordas), com finas bordas de oxidação ou parcialmente oxidados (principalmente os menores). Observou-se um cristal zonado com grande quantidade de inclusões no núcleo. Cpx ocorre como pequenos cristais, podendo apresentar inclusões de plg e zircão, ou estar associado a bt.

Opacos e acessórios: opacos como produto de alteração de minerais máficos. Zircão e apatita como acessórios

Bt: biotita; Cpx: clinopiroxênio; Hbl:hornblenda; Ilm: Ilmenita; Mgn: magnetita; Opx: ortopiroxênio; Plg: plagioclásio; Qtz: quartzo; 
PUL 21

Ponto: 09 - UFRS

\section{Descrição macroscópica}

Matriz rica em cristaloclastos e púmices na fração lapilli-cinza. A matriz apresenta abundancia em fenocristais de bt (oxidado) e minerais félsicos. Os fragmentos de púmice ocorrem como fiammes rosados contendo microfenocristais (maiores que os cristais da matriz) de minerais máficos (bt e px) e minerais félsicos (qtz e plg). A amostra está soldada e pode ter sido afetada por alteração ou cristalização fase-vapor.

\section{Descrição microscópica}

Amostra de ignimbrito desvitrificado e afetado por soldamento. A matriz apresenta textura vitroclástica não sendo muito evidente a textura eutaxítica. Os púmices apresentam desvitrificação esferulítica e ocorrem em fiammes, sendo que os cristais não se encontram orientados e há ausência de reomorfismo. Identificaram-se glassshard não afetados por soldamento que ainda puderam ser reconhecidas devido à textura de desvitrificação (esferulítica na porção interna e axiolítica próximo as paredes).

Quartzo: cristais idiomórficos (hexagonais) ou fragmentados, embainhados e/ou com bordas arredondadas. Alguns fenocristais poiquilíticos $(<1,5 \mathrm{~mm})$ englobam pequenos glomérulos de plg idiomórfico e também bt, opx e opacos. É freqüente a inclusão de micrólitos de plg nos cristais.

Plagioclásio: Os cristais estão fragmentados ou fraturados. Muitos apresentam feições de dissolução ou inclusões, podendo estar associado ou não a um zoneamento irregular complexo e com extinção ondulante. Alguns poucos cristais apresentam seu núcleo corroído (textura do tipo peneira) como vestígio de exsolução ou dissolução. Podem também apresentar concentrações de inclusões fluídas acompanhando a borda de algumas zonas composicionais do cristal. Suas bordas também podem apresentam-se angulosas e/ou corroídas. Muitos estão intercrescidos com bt e opacos e os cristais maiores ocorrem nas bordas de vesículas ou formando glomérulos.

Biotita: Ocorre bastante oxidada e com bordas de alteração. Apresenta inclusões de plg ou está intercrescida ao mesmo. Também apresenta inclusões de px, qtz e opacos.

Outros máficos (opx, cpx e hbl): Os cristais de opx são euédricos a xenomórficos, com abundantes fraturas e com finas bordas de oxidação. Muitos estão parcialmente dissolvidos (arredondados), podendo, além do mais, estar intercrescido ao plg. O cpx é raro e ocorre no púmice com formas subédricas, fragmentado e com bordas de oxidação. Não foi observado hbl.

Opacos e acessórios: opacos como produto de alteração de minerais máficos. Zircão e apatita como acessórios.

\section{PUL 24}

Ponto: $10 b$ - UFC 


\section{Descrição macroscópica}

Matriz e lapilli-púmice. A matriz é afanítica, de cor rosa-acinzentada, rica em cristaloclastos e púmices na fração cinza. Apresenta abundancia em cristais de bt (oxidados) e minerais félsicos (plg e qtz). O fragmento de lapilli-púmice apresenta uma tonalidade mais clara que a matriz, devido à presença de vários aglomerados de minerais félsicos, que também bordejam algumas pequenas vesículas. A granulometria dos cristais é mais grossa $(<2,0 \mathrm{~mm})$, podendo-se observar, além dos minerais félsicos (qtz e plg), a presença de minerais máficos, como bt e px, já oxidados e menores que $1,0 \mathrm{~mm}$. A amostra está soldada e pode ter sido afetada por alteração ou cristalização fase-vapor.

\section{Descrição microscópica}

Amostra de ignimbrito desvitrificado e afetado por leve soldamento. A matriz apresenta textura vitroclástica não sendo evidente a textura eutaxítica. Os púmices apresentam desvitrificação esferulítica e ocorrem em fiammes sendo que os cristais não se encontram orientados e há ausência de reomorfismo. Fragmentos líticos angulosos de origem sedimentar também foram observados.

Quartzo: No púmice o quartzo pode ocorrer como fenocristais de bordas arredondadas (o que the propicia o aspecto de gota) ou com diferentes graus de engolfamento. Alguns exemplares ocorrem como cristais poiquíliticos englobando pequenos cristais de plagioclásio euédricos. Na matriz o quartzo também ocorre arredondado e/ou engolfado;

Plagioclásio: Ocorre como fenocristais euédricos a subédricos com bordas parcialmente reabsorvidas e/ou bastante fragmentadas tanto no púmice como na matriz. Em ambos, o mineral apresenta zoneamento e textura de desequilíbrio (como textura em peneira ou esponjosa) acompanhando ou não o zoneamento;

Biotita: Apresenta-se oxidada e com coloração avermelhada, como pequenas placas finas ou como grandes fenocristais com muitas inclusões de cpx, qtz e plg. Na matriz a biotita ocorre bem mais fragmentada, constituindo boa porcentagem das cinzas do ignimbrito (matriz);

Outros máficos (opx, cpx e hbl): na matriz opx ocorre como fenocristais subédricos a euédricos com finas bordas de oxidação e intensamente fraturado. No púmice, o mineral ocorre bastante fragmentado, fraturado e/ou oxidado não sendo possível comprovar, se de fato, se trata de opx. O $\mathrm{cpx}$ é o segundo mineral máfico predominante, sendo encontrado principalmente no púmice. Apresenta-se como mineral euédrico a subédrico, com bordas muito finas de oxidação (por vezes também ausentes) e granulometria menor que o opx. Já a presença de hbl é esporádica, sendo encontrada principalmente no púmice, com formas euédricas a subédricas, pequena granulometria e sem bordas de oxidação.

Opacos e acessórios: ocorre como produto de alteração de minerais máficos.

\section{PUL 25A}

Ponto: $10 \mathrm{C}$ - UFRS

Bt: biotita; Cpx: clinopiroxênio; Hbl:hornblenda; Ilm: Ilmenita; Mgn: magnetita; Opx: ortopiroxênio; Plg: plagioclásio; Qtz: quartzo; 
Amostra de lapilli-púmice com textura vitroclástica e matriz afetada por desvitrificação esferulítica. Apresenta uma grande quantidade de cristais (30\%). O qtz ocorre como cristais fragmentados, embainhados, com bordas arredondadas ou completamente arredondados. Alguns cristais ainda exibem suas formas hexagonais. Podem ocorrer como fenocristais de até $1,4 \mathrm{~mm}$ (apresentando inclusões de plg), como cristais poiquilíticos $(<1,25 \mathrm{~mm})$ englobando pequenos cristais de plg. Também se observou 0 quartzo manteando um fenocristal de plg. Os cristais de plg estão fragmentados ou fraturados. A geminação albítica se impõe sobre o zoneamento. Muitos apresentam feições de dissolução ou inclusões, podendo estar associado ou não a um zoneamento irregular complexo e com extinção ondulante. Alguns poucos cristais apresentam seu núcleo corroído (textura esponjosa) como vestígio de exsolução ou dissolução. Podem também apresentar concentrações de inclusões fluídas acompanhando a borda de algumas zonas composicionais do cristal. Outros apresentam seu zoneamento truncado com borda de sobrecrescimento, indicando um cristal original bem maior. Suas bordas também podem apresentam-se angulosas e/ou corroídas. Muitos estão intercrescidos com biotita e opacos e os cristais maiores ocorrem nas bordas de vesículas ou formando glomérulos.

\section{PUL 25c}

Ponto: 10C - UFRS

\section{Descrição macroscópica}

Ignimbrito com fragmento lítico vermelho. A matriz do ignimbrito apresenta coloração rosa-acinzentada e é rica em fenocristais, apresentando também pequenos púmices. Podem-se identificar minerais máficos oxidados (provavelmente bt, px e anf) e alguns minerais félsicos (provavelmente plg e qtz). Observa-se que os minerais máficos apresentam uma tendência de orientar-se segundo a direção de soldamento que afetou a rocha. O fragmento apresenta um bandamento que varia entre rosa $\mathrm{e}$ vermelho escuro e a ponta do fragmento ocorre em "flame". Nota-se também a presença de pequenos cristais dentro do fragmento. A amostra está soldada e pode ter sido afetada por alteração ou cristalização fase-vapor.

\section{Descrição microscópica}

Amostra de matriz com fragmento lítico em fiamme e terminações em flame (trata-se provavelmente de tufo intensamente soldado ou um outro tipo de púmice).

Quartzo: cristais idiomórficos (hexagonais) ou fragmentados, embainhados e/ou com bordas arredondadas. Alguns fenocristais poiquilíticos $(<1,4 \mathrm{~mm})$ englobam pequenos glomérulos de plg, eu a subédricos, com ou sem zoneamento.

Plagioclásio: Os cristais estão fragmentados ou fraturados. Muitos apresentam feições de dissolução ou inclusões, podendo estar associado ou não a um zoneamento irregular complexo e com extinção ondulante. Alguns poucos cristais apresentam seu núcleo corroído (textura do tipo peneira) como vestígio de exsolução ou dissolução. Podem também apresentar concentrações de inclusões fluídas acompanhando a borda de algumas zonas composicionais do cristal. Suas bordas também podem apresentam-se angulosas e/ou corroídas. Muitos estão intercrescidos com bt ou apresentam inclusões de opx e opacos. Observa-se que a geminação se 
impõe sobre o zoneamento e em outras o zoneamento ocorre truncado por um posterior crescimento do cristal.

Biotita: Ocorre bastante oxidada e com espessa borda de alteração. Apresenta inclusões de px ou plg e pode estar intercrescida ao mesmo. Também apresenta inclusões de opacos.

Outros máficos (opx, cpx e hbl): Os cristais de opx são pequenos cristais $(<0,5 \mathrm{~mm})$ euédricos a subédricos, apresentam bordas de oxidação com inclusões de minúsculos cristais de plg ou apatita. O cpx ocorre como fragmentos ou como pequenos grãos $(<0,3 \mathrm{~mm})$ idiomórficos a xenomórficos. Pode apresentar inclusões de plg.

Opacos e acessórios: opacos como produto de alteração de minerais máficos. Zircão e apatita como acessórios, por vezes inclusos nos minerais máficos.

\section{PUL 26a}

Ponto: 10D - UFRS

\section{Descrição Macroscópica}

Amostra da matriz do depósito superior com alguns púmices na fração lapilli-cinza. A matriz do ignimbrito está soldada e apresenta coloração rosa-acinzentada escura. É rica em microfenocristais de minerais máficos oxidados (provavelmente bt, além de px e anf) e alguns minerais félsicos (plg e qtz). Observa-se um fiamme, provável fragmento lítico, de coloração vermelha e, aparentemente, oxidado. Os lapilli-púmices são quase imperceptíveis, pois estão bem soldados e tem uma cor semelhante a matriz. Observam-se vesículas que aparentemente se encontram tanto na matriz como nos púmices, porém não é certo afirmar, já que está muito difícil de diferenciar o púmice da matriz. Estas vesículas são do tipo lithophysaes, com pequenos cristais em sua parede interna, e ocorrem estiradas acompanhando o plano de soldamento da rocha. A rocha parece ter sido afetada por alteração ou cristalização fase-vapor (aparentemente silicíficada).

\section{Descrição Microscópica}

Amostra de matriz com púmices e pequenos fragmentos líticos dispersos na matriz. A matriz apresenta uma marcante textura eutaxítica, moldando-se a púmices, cristaloclastos e líticos. A desvitrificação e achatamento são intensos nos púmices, porém ainda se identificam as paredes das bolhas. A desvitrificação é do tipo esferulítica dispersa, ocorrendo também a textura microgranofírica. Vesículas maiores ocorrem preenchidas, constituindo lithophysaes. Um dos fragmentos líticos aparenta ser uma rocha vulcânica ou algum aglomerado máfico. Estes líticos apresentam uma forma arredondada e são eqüidimensionais aos cristais maiores do tipo poiquilíticos (qtz). Os cristaloclastos são euédricos, sendo que fenocristais poiquilíticos de qtz estão arredondados e embainhados, podendo-se ainda, em alguns casos, observar sua forma hexagonal original.

Quartzo: cristais idiomórficos (hexagonais) ou fragmentados, embainhados e/ou com bordas arredondadas. Alguns fenocristais poiquilíticos $(<1,6 \mathrm{~mm})$ englobam pequenos glomérulos de plg eu a subédricos, que pode estar ou não zonado. Uma maior 
concentração deste mineral ocorre na parte interna de algumas estruturas lithophysaes.

Plagioclásio: Os cristais estão fragmentados ou fraturados. Muitos apresentam feições de dissolução ou inclusões (fluídas ou de outro plg), podendo estar associado ou não a um zoneamento irregular complexo e com extinção ondulante. Alguns poucos cristais apresentam seu núcleo corroído (textura do tipo peneira) como vestígio de exsolução ou dissolução. Podem também apresentar concentrações de inclusões fluídas acompanhando a borda de algumas zonas composicionais do cristal. Suas bordas também podem estar angulosas e/ou corroídas. Muitos estão intercrescidos com bt ou apresentam inclusões de opx e opacos. Observa-se que a geminação se impõe sobre o zoneamento.

Biotita: Ocorre bastante oxidada, com espessa borda de alteração. Apresenta inclusões de plg ou ocorre como agregados junto ao px. Provável constituinte da borda de alteração do anf oxidado. Também apresenta inclusões de opacos.

Outros máficos (opx, cpx e hbl): Opx ocorre principalmente como fenocristais a microcristais dispersos euédricos a subédricos, com bordas de oxidação e freqüentes inclusões de plg. Alguns cristais encontram-se fraturados ou com bordas arredondadas (principalmente na matriz). O cpx é mais raro e está bastante fragmentado. Ocorre como pequenos grãos euédricos a xenomórficos, apresentando uma inclusão de bt.

Opacos e acessórios: opacos como produto de alteração de minerais máficos. Zircão e apatita como acessórios.

\section{PUL 27}

Ponto: 11 - Depósito piroclástico de composição riolítica, embaixo dos depósitos do cerro Pululus.

\section{Descrição Macroscópica}

Amostra retirada da matriz do depósito, apresentando pequeno fragmento lítico (com $1 \mathrm{~cm}$ de diâmetro) e pequenos lapilli-cinza púmices (todos $<2 \mathrm{~mm}$ ). A matriz é leucocrática de coloração rosada, apresentando cristaloclastos de minerais máficos e félsicos (em <\%). Observam-se vesículas arredondadas na matriz do ignimbrito o que é uma boa evidência de que não ocorreu soldamento nesta rocha. Também ocorre uma discreta orientação dos minerais prismáticos e placóides devido a compactação. A rocha não aparenta ter sofrido alteração fase-vapor.

\section{Descrição Microscópica}

Amostra da matriz do ignimbrito, com pequenos fragmentos de lítico e púmices. A matriz apresenta textura eutaxítica, com suave orientação dos minerais máficos alongados. Púmices com vesículas e shards dispersos na matriz também denunciam uma suave compactação na mesma orientação dos minerais. A rocha é bem rica em qtz, contendo também plg, finas placas de bt (de até $3 \mathrm{~mm}$ de comprimento), sericita e opacos avermelhados. Estes minerais são abundantes tanto nos púmices como na matriz.

PUL 28a

Ponto: 13 - UFRS 


\section{Descrição Macroscópica}

Matriz e fragmento de lapilli-púmice. A matriz é afanítica porfirítica, com cristaloclastos $(<2 \mathrm{~mm})$ de minerais máficos oxidados e alguns félsicos (plg e qtz). Pequenos fiammes de púmices escuros $(<0,8 \times 5 \mathrm{~mm})$ também ocorrem dispersos na matriz acompanhando a mesma orientação observada em minerais mais alongados. $O$ fragmento de púmice apresenta uma coloração mais clara e cinzenta, com maior quantidade de minerais félsicos. Estes minerais parecem ocorrer como aglomerados, provavelmente preenchendo vesículas. Também se identificam minerais máficos oxidados com a mesma granulometria encontrada na matriz. A amostra está soldada e foi afetada por alteração ou cristalização fase-vapor, apresentando algumas porções amareladas.

\section{Descrição Microscópica}

Amostra de ignimbrito soldado, desvitrificado e afetado por alteração fase-vapor. A matriz apresenta textura eutaxítica, parcialmente encoberta por sericitização (fasevapor). Fragmentos de shards são identificados devido a desvitrificação e cristais de bt acompanham a direção de compactação e da textura eutaxítica. Os pequenos púmices que ocorrem na matriz encontram-se soldados, desvitrificados e com finalizações em chama (textura flame, bordas pouco definidas mesclando-se a matriz). No fragmento de lapilli-púmice ocorrem aglomerados de cristais de plg e qtz e na matriz ocorrem aglomerados de plg e minerais máficos ( $\mathrm{px}$, bt e opacos, as vezes com plg). A bt ocorre bastante oxidada, por vezes completamente substituída por opacos, ou apenas com espessas bordas de alteração. Apresenta inclusões de plg ou está intercrescida ao mesmo, e também apresenta inclusões de px, qtz e opacos. O qtz aparece como cristais idiomórficos (hexagonais) ou fragmentados, embainhados e/ou com bordas arredondadas. Alguns fenocristais poiquilíticos $(<1.8 \mathrm{~mm})$ englobam pequenos glomérulos de plg idiomórfico e também bt, opx e opacos.

\section{PUL 28B}

Ponto: 13 - UFRS

\section{Descrição Macroscópica}

Amostra de lapilli-púmice de coloração rosa-acinzentada. Contêm uma grande quantidade de fenocristais máficos (já oxidados) e félsicos (ambos $<2 \mathrm{~mm}$ ). Estruturas lithophysaes ocorrem dispersas na amostra e sua coloração amarelada evidencia que teria sido afetada por alteração fase-vapor ou hidrotermal. Alguns fenocristais félsicos parecem representar os glomérulos de plg englobados por qtz poiquílitico.

\section{Descrição Microscópica}

Amostra de lapilli-púmice afetada por alteração fase-vapor e com estágio avançado de oxidação. A matriz do púmice apresenta textura de desvitrificação do tipo esferulítica com presença de estruturas lithophysaes. A alteração fase-vapor fica evidente com a sericitização presente.

Quartzo: ocorre principalmente como fenocristais poiquilíticos $(<3,5 \mathrm{~mm})$ que englobam pequenos glomérulos de plg idiomórfico (zonados e geminados) e também

Bt: biotita; Cpx: clinopiroxênio; Hbl:hornblenda; Ilm: Ilmenita; Mgn: magnetita; Opx: ortopiroxênio; Plg: plagioclásio; Qtz: quartzo; 
bt, opx e opacos. Alguns cristais menores e sem inclusões são idiomórficos ou estão fragmentados, embainhados e/ou com bordas arredondadas. É freqüente também a inclusão de micrólitos de plg nos cristais.

Plagioclásio: Os cristais estão fragmentados ou fraturados e a maioria foi afetada por sericitização devido à alteração fase-vapor. Feições de dissolução ou inclusões podem estar, ou não, associados a um zoneamento irregular complexo e a extinção ondulante. Alguns poucos cristais apresentam seu núcleo corroído (textura esponjosa) como vestígio de exsolução ou dissolução. Podem também apresentar concentrações de inclusões fluídas acompanhando a borda de algumas zonas composicionais do cristal. Suas bordas também podem apresentam-se angulosas e/ou corroídas. Muitos estão intercrescidos com bt e opacos e os cristais maiores ocorrem nas bordas de vesículas ou formando glomérulos;

Biotita: Ocorre bastante oxidada e com bordas de alteração. Apresenta inclusões de plg ou está intercrescida ao mesmo. Também apresenta inclusões de px, qtz e opacos.

Outros máficos (opx, cpx e hbl): opx ocorre como microfenocristais subédricos, $<0,3 \mathrm{~mm}$, com finas a grossas bordas de oxidação (confererindo-lhe uma coloração avermelhada), podem além do mais estar parcialmente reabsorvido (com bordas arredondadas). Encontram-se intercrescidos ao plg e também apresentam contato de reação com bt e opacos. O cpx ocorre manteando um opx e também como pequenos cristais subédricos no púmice.

Opacos e acessórios: opacos como produto de alteração de minerais máficos. Zircão e apatita como acessórios.

\section{PUL 28C}

Ponto: 13 - UFRS

\section{Descrição Macroscópica}

Amostra de fragmento vermelho, que ocorre como fiamme. Este lítico ocorre nos depósitos do Cerro Pululus como fragmentos angulosos de granulação variada (geralmente $<3 \mathrm{~mm}$, podendo alcançar dimensões de bloco superiores a $15 \mathrm{~cm}$ ) ou como fiammes de até $10 \mathrm{~cm}$. $\mathrm{O}$ fragmento aqui amostrado representa um fiamme, com bandamento interno descontinuo. É importante mencionar que estes fragmentos apresentam inclusões de outros pequenos fragmentos líticos, que não se deformam e são moldados pela matriz do próprio lítico.

\section{Descrição Microscópica}

Este lítico parece representar um fragmento de lapilli-tufo oxidado, de coloração avermelhada. Apresenta $15-20 \%$ de cristaloclastos bem selecionados (principalmente qtz e plg), $25-30 \%$ de púmices em fiamme e $10 \%$ de fragmentos líticos diversos (origem vulcânica e sedimentar).

PUL 29

Ponto: 15 - UFRI

\section{Descrição Macroscópica}


Matriz com lapilli-púmice branco em fiamme. A matriz do ignimbrito é afanítica porfirítica de coloração rosa, com cristaloclastos $(<1 \mathrm{~mm})$ de minerais máficos oxidados e de agregados de minerais félsicos (plg e qtz). Pequenos fiammes de púmices (<2mm) também ocorrem dispersos na matriz, acompanhando a mesma direção de soldamento dos lapillis. Ambos apresentam uma coloração branca acinzentada com uma borda de tonalidade cinza-escura. Dentro dos púmices os cristais estão menos fragmentados e conseqüentemente maiores que na matriz. Também se observam vesículas nos púmices com preenchimento total ou parcial

PUL 30a

Ponto: $18 b$ - UFRI

\section{Descrição Macroscópica}

Amostra de matriz constituída por pequenos fragmentos de lapilli-púmices soldados (e outros menores de $2 \mathrm{~mm}$ ) e pequenos cristaloclastos. Tanto os púmices como a matriz são ricos em cristais e cor rosa-acinzentados. Há porções na matriz que são de tonalidade mais escura, tratando-se, provavelmente, das bordas difusas de púmices em resposta ao forte soldamento que afetou a rocha. Ocorrem cristaloclastos $(<1 \mathrm{~mm})$ de minerais máficos oxidados e poucos agregados de minerais félsicos (plg e qtz). Os minerais aparentemente não apresentam nenhuma direção preferencial, sendo que as placas de bt estão dispersas sem orientação evidente.

\section{Descrição Microscópica}

Amostra da matriz de ignimbrito soldado, desvitrificado e bastante afetado por alteração fase-vapor. Os púmices $(<4 \mathrm{~mm})$ ocorrem dispersos e apresentam uma textura de desvitrificação do tipo esferulítica plumosa, estando pouco afetados pela sericitização. A sericitização mostra-se bastante avançada na matriz, observando-se o crescimento de minerais como produto de alteração da bt. Há também, a presença de glomérulos de minerais máficos associados ao plg.

Quartzo: cristais idiomórficos (hexagonais) ou fragmentados, com forte embainhamento e/ou com bordas arredondadas. Alguns fenocristais poiquilíticos $(<1.8 \mathrm{~mm})$ englobam pequenos glomérulos de plagioclásio idiomórfico e também bt, opx e opacos. É freqüente a inclusão de micrólitos (plg???) nos cristais;

Plagioclásio: Os cristais estão bastante fragmentados ou fraturados e com forte sericitização (principalmente nas bordas e através de fraturas). Feições de dissolução ou inclusões ocorrem associadas a um zoneamento irregular complexo e a extinção ondulante do mineral. Alguns poucos cristais apresentam seu núcleo corroído (textura esponjosa) como vestígio de exsolução ou dissolução. Podem também apresentar concentrações de inclusões fluídas acompanhando a borda de algumas zonas composicionais do cristal. Suas bordas também podem apresentam-se angulosas e/ou corroídas. Muitos estão intercrescidos com bt e opacos e os cristais maiores ocorrem nas bordas de vesículas ou formando glomérulos com minerais máficos e opacos.

Biotita: Intensamente alterada ou com grossas bordas de oxidação. Também pode estar afetada pela sericitização. É comum apresentar inclusões de plg ou estar intercrescida ao mesmo. Também apresenta inclusões de px, qtz e opacos.

Bt: biotita; Cpx: clinopiroxênio; Hbl:hornblenda; Ilm: Ilmenita; Mgn: magnetita; Opx: ortopiroxênio; Plg: plagioclásio; Qtz: quartzo; 
Outros máficos (opx, cpx e hbl): Opx apresenta espessas bordas de oxidação e podem ocorrer como microcristais em glomérulos com plg, bt e cpx. microfenocristais de cpx estão fragmentados e dispersos nos púmices ou, eventualmente, nos glomérulos. Não se observa hbl.

Opacos e acessórios: opacos como produto de alteração de minerais máficos.

PUL 30P

Ponto: 18b - UFRI

\section{Descrição Macroscópica}

Amostra de lapilli-púmice de coloração roxo-claro acinzentado e pequena porção de matriz de coloração rosa-claro. O púmice apresenta uma grande quantidade de fenocristais máficos e félsicos. Alguns fenocristais félsicos parecem representar os glomérulos de plg englobados por qtz poiquílitico. Também pode haver estruturas lithophysaes.

\section{Descrição Microscópica}

Amostra de lapilli-púmice afetada intensamente por alteração fase-vapor e com alto grau de desvitrificação. A textura predominante é de desvitrificação do tipo esferulítica e microgranofírica. A alteração fase-vapor fica evidente pela forte sericitização que afetou principalmente os cristais de plg e fraturas que atravessam minerais máficos, como bt e opx.

Quartzo: ocorre principalmente como fenocristais poiquilíticos $(<1,25 \mathrm{~mm})$ que englobam pequenos glomérulos de plg idiomórfico (zonados e geminados) e também bt, opx e opacos. Cristais menores e com pouca ou nenhuma inclusão são idiomórficos ou estão fragmentados, embainhados e/ou com arestas retas e bordas arredondadas. É freqüente também a inclusão de micrólitos de plg nos cristais.

Plagioclásio: Os cristais estão fragmentados ou fraturados e a maioria foi afetada por sericitização devido à alteração fase-vapor. Observam-se feições de dissolução e/ou inclusões, que estão, ou não, associados a um zoneamento irregular complexo e/ou a extinção ondulante. Alguns poucos cristais apresentam seu núcleo corroído (textura esponjosa) como vestígio de exsolução ou dissolução. Podem também apresentar concentrações de inclusões fluídas acompanhando a borda de algumas zonas composicionais do cristal. Suas bordas também podem apresentar-se angulosas e/ou corroídas. Muitos estão intercrescidos com biotita e opacos e os cristais maiores ocorrem nas bordas de vesículas ou formando glomérulos;

Biotita: Ocorre bastante alterada com bordas de oxidação. Apresenta inclusões de plg ou está intercrescida ao mesmo. Também apresenta inclusões de opx, qtz e opacos.

Outros máficos (opx, cpx e hbl): Em porções onde ocorrem maiores concentrações de opx ele ocorre como microfenocristais intercrescidos à pequenos cristais de plg. Poucos cristais de cpx e apenas uma hbl foram encontrados.

PUL 31

Ponto: $18 c$ - UFRI

Descrição Macroscópica 
Amostra da matriz do ignimbrito com lapilli-púmice. A matriz apresenta uma coloração mais rosada que o púmice (rosa-azulado nas bordas e cinza no centro), e seus cristais estão mais fragmentados (com menor granulometria). Reconhecem-se cristaloclastos $(<4 \mathrm{~mm})$ de minerais máficos oxidados e agregados de minerais félsicos (plg com qtz) de até $5 \mathrm{~mm}$. Estes agregados aparecem principalmente nos púmices preenchendo possíveis vesículas. Os minerais aparentemente não apresentam nenhuma direção preferencial

\section{PUL 32}

Ponto: $18 \mathrm{a}$ - base UFRI

\section{Descrição Macroscópica}

Matriz com lapilli-púmices soldados. A matriz do ignimbrito é afanítica porfirítica de coloração rosa clara acinzentada e amarelada (devido a alteração fase-vapor que afetou a rocha no afloramento), com cristaloclastos $(<4 \mathrm{~mm})$ de minerais máficos oxidados e de agregados de minerais félsicos (plg e qtz). Pequenos lapilli-púmices também ocorrem dispersos na matriz, apresentando uma grande concentração de aglomerados félsicos (plg e qtz que preencheram vesículas). Estes pequenos fragmentos assim como o púmice maior (bloco, $>7 \mathrm{~cm}$ ), apresentam uma coloração mais azulada à acinzentada com vesículas amarelas. Dentro dos púmices os cristais estão menos fragmentados e conseqüentemente maiores que na matriz. Os minerais não apresentam nenhuma direção preferencial de alinhamento.

\section{Descrição Microscópica}

Amostra de matriz com pequenos lapilli-púmices dispersos. A rocha está soldada, desvitrificada e afetada por alteração fase-vapor. A matriz apresenta textura do tipo eutaxítica. Tanto os púmices (em sigmóides) como os cristaloclastos evidenciam um suave reomorfismo. A alteração fase-vapor resultou em uma sericitização que afeta principalmente a matriz e a desvitrificação do tipo esferulítica plumosa ocorre nas porções centrais dos púmices passando para microgranofírica nas bordas.

Quartzo: cristais idiomórficos (hexagonais) ou fragmentados, embainhados e/ou com bordas arredondadas. Alguns fenocristais poiquilíticos englobam pequenos glomérulos de plg idiomórfico e também bt, opx e opacos.

Plagioclásio: Os cristais estão bastante fragmentados ou fraturados e muitos apresentam sericitização (principalmente os cristaloclastos dispersos na matriz). Predominam s cristais limpos, sem zoneamento ou com zoneamento simples. Também observam-se feições de dissolução ou inclusões, associadas a um zoneamento irregular complexo e a extinção ondulante. Alguns poucos cristais apresentam seu núcleo corroído (textura esponjosa) como vestígio de exsolução ou dissolução. Podem também apresentar concentrações de inclusões fluídas acompanhando a borda de algumas zonas composicionais do cristal. Suas bordas também podem apresentam-se angulosas e/ou corroídas. Muitos estão intercrescidos com biotita e opacos e os cristais maiores ocorrem nas bordas de vesículas ou formando glomérulos. 
Biotita: concentra-se principalmente na matriz como finas placas. Ocorre bastante oxidada e afetada pela sericitização. Apresenta inclusões de plg ou está intercrescida ao mesmo. Também apresenta inclusões de px, qtz e opacos.

Outros máficos (opx, cpx e hbl): A maioria ocorre apenas como pseudomorfos. Podem estar intercrescidos ou associados ao plg.

\section{PUL 33E}

Ponto: 19 - UFC

\section{Descrição Macroscópica}

Amostra de fragmento lítico com porção da matriz. Rocha leucocrática de coloração violeta escura, afanítica, maciça. Na luz pode-se distinguir pelo brilho pequenos cristais de quartzo (?).

\section{Descrição Microscópica}

O fragmento representa uma rocha metassedimentar, constituído apenas por quartzo (textura em mosaico) e placas de biotita. A pequena porção de matriz do ignimbrito que ocorre na lâmina apresenta-se desvitrificada e sericitizada, com mineralogia constituída por plg (40\%), grãos de qtz reabsorvidos (30\%), bt (15\%), opx (8\%) e cpx (4\%).

\section{PUL 33PH}

Ponto: 19 - UFC

\section{Descrição Macroscópica}

Amostra de lapilli-púmice de coloração branca e rosa acinzentada. A coloração branca é resultado dos aglomerados de minerais félsicos, como plg e qtz. Em meio a esses aglomerados observam-se vesículas com as paredes forradas de microcristais de quartzo. Os minerais máficos presentes já estão oxidados e por vezes também parecem ocorrer como aglomerados cercados por félsicos. É provável que as porções mais rosadas representem a matriz do púmice e nota-se que no seu centro a cor se torna cinza.

\section{Descrição Microscópica}

Púmice desvitrificado, soldado e afetado por alteração fase-vapor. Apresenta textura de desvitrificação avançada, com a formação de esferulitos completos e parciais. Também ocorrem fans abertos que mudam para textura microgranofírica. Os esferulitos ocorrem dispersos na matriz do púmice, sendo que muitos se formam a partir de núcleos de qtz. Entre os cristaloclastos (55-60\%) têm-se plg (25\% - euédrico a sub-édrico, serecitizado nas bordas) qtz (15\% euédrico, com golfos de embainhamento de diferentes intensidades), px ( $8 \%$ euédrico e geminado, com bordas de oxidação e de anf e bt), hbl (<2\%, como microcristais com espessas bordas de alteração e como pseudomorfos), bt ( $<15 \%$, tabulares, alterados parcialmente como pseudomorfos - já substituídos por opacos- e como alteração do anfibólio e px). Presença também de microcristais de apatita, zircão e mgn dispersos a matriz ou como inclusões em outros minerais. 


\section{PUL 33PI}

Ponto: 19 - UFC

\section{Descrição Macroscópica}

Amostra de bloco-púmice de cor marrom avermelhado com pequena porção da matriz. O púmice apresenta vesículas achatadas, parcialmente (apenas nas paredes) ou completamente preenchidas por minerais félsicos (alcançado até $1 \mathrm{~cm}$ de comprimento) e minerais máficos oxidados menores que $3 \mathrm{~mm}$ (estes se confundem a matriz por apresentarem cores muito semelhantes). O contato do púmice com a matriz é um pouco difuso.

\section{Descrição Microscópica}

Fragmento de púmice com pequena porção da matriz. A amostra está soldada e afetada por alteração fase-vapor. Há uma grande quantidade de vesículas no púmice, compactadas e preenchidas posteriormente por produtos de alteração fase-vapor (qtz, felds, vidro e opacos). A textura do tipo esferulítica se desenvolveu principalmente no púmice e não se observam tais texturas na matriz. Os cristaloclastos são: qtz (euédricos com bordas de oxidação e quebrados), plg (menos fraturados no púmice, quebrados, alterados e como produto de alteração de outros máficos, também ocorrendo como pseudomorfo), hbl (subédrica, biotitizada e como pseudomorfo) e opx (como cristais euédricos, fraturados e com avançadas bordas de oxidação). Presença de aglomerados máficos com plg tanto na matriz como no púmice. No contato entre ambos há uma pequena porção muito soldada semelhante ao fragmento vermelho em fiamme.

\section{PUL 34}

Ponto: 20 - UFRI

\section{Descrição Macroscópica}

Amostra de matriz com lapilli-púmice. Rocha de coloração rosa-cinzenta com porções brancas, cristaloclastos e púmices cinzas e brancos. Grande parte das porções brancas representa glomérulos de cristaloclastos de minerais félsicos (qtz e plg). Os minerais máficos estão oxidados. Os fragmentos de púmice estão soldados e apresentam uma cor cinza e bordas mais avermelhadas, com fenocristais de minerais máficos e félsicos. Suas bordas estão levemente difusas, com terminações em chamas.

\section{Descrição Microscópica}

Amostra de matriz com lapilli-púmice. A matriz apresenta uma textura do tipo eutaxítica com pequenos fragmentos de púmice moderadamente soldados. Texturas de desvitrificação afetam mais os púmices (do tipo esferulítica e microgranofírica) e a alteração fase-vapor afeta principalmente os cristaloclastos máficos da matriz.

Quartzo: cristais fragmentados, embainhados ou com bordas arredondadas. Em alguns ainda é possível definir suas formas hexagonais. Fenocristais poiquilíticos $(<1,8 \mathrm{~mm})$, também de forma hexagonal, englobam pequenos cristais de plg e/ou bt;

Bt: biotita; Cpx: clinopiroxênio; Hbl:hornblenda; Ilm: Ilmenita; Mgn: magnetita; Opx: ortopiroxênio; Plg: plagioclásio; Qtz: quartzo; 
Plagioclásio: fragmentados ou fraturados, principalmente os cristais maiores. Apresentam zoneamento irregular, com texturas de dissolução acompanhando o zoneamento ou apenas com seu núcleo corroído (textura esponjosa). Também apresenta concentrações de inclusões fluídas acompanhando a borda de alguns cristais. Suas bordas também podem apresentam-se angulosas e/ou corroídas. Muitos estão intercrescidos com bt e opacos e apresentam cristais menores de plg;

Biotita: Apresenta-se bastante oxidada. Muitos apresentam inclusões de plg ou estão intercrescidos a estes. Também ocorre associada aos glomérulos de plg.

Outros máficos (opx, cpx e hbl): A identificação do mineral é dificultada pelo avançado estado de alteração e oxidação. A maior parte apresenta grossas bordas de oxidação de coloração avermelhada e apenas o núcleo ainda está preservado, destes se identifica o opx, com grossas bordas de oxidação e inclusões de plg e opacos. Outros opx apresentam feições de dissolubilidade interna. Também podem formar aglomerados ou estarem englobados por plg. O cpx é menos freqüente e apresenta grossas bordas de oxidação. Não se encontrou hbl.

Opacos: ocorrem como minerais avermelhadas.

\section{PUL 36a}

Ponto: 22 - UFRI

\section{Descrição Macroscópica}

Amostra de fragmento lítico em contato com matriz do ignimbrito. A matriz apresenta coloração rosa-avermelhada, com presença de cristaloclastos félsicos e máficos e também um lapilli-púmice que se amolda na forma do lítico. O fragmento lítico apresenta uma coloração escura (mesocrática) e granulação afanítica. Concentração de grandes fenocristais oxidados de biotita vai ficando mais escassa do centro a borda do fragmento onde a uma maior concentração de plagioclásio. Também se observam pequenos cristais avermelhados, que variam para cores mais cinzas. No contato do lítico com a matriz há uma grande concentração deste mineral vermelho (algum tipo de opaco). O púmice é cinza com presença de vesículas parcialmente preenchidas.

\section{PUL 36c}

Ponto: 22 - UFRI

\section{Descrição Macroscópica}

Amostra de lapilli-púmice e da matriz do ignimbrito. O púmice é de coloração marrom esbranquiçado. Ocorrem muitos fenocristais máficos bastante oxidados e um fenocristal maior de px. O púmice apresenta bastante vesicularidade, com vesículas levemente achatadas. A matriz é de coloração mais avermelhada, com cristais mais fragmentados e uma menor \% de cristais félsicos. Observa-se um aglomerado de plg associado a máficos e englobados por uma borda de qtz.

\section{Descrição Macroscópica}

Amostra de púmice branco em matriz de ignimbrito. Este púmice apresenta textura de desvitrificação do tipo esferulítica dispersa entre textura microgranofírica. A rocha também é afetada por alteração fase-vapor, sendo que os cristaloclastos máficos da 
matriz estão mais afetados que o púmice e seus fenocristais. Ocorrem aglomerados de plg englobados por cristal poiquilíticos qtz de $5 \mathrm{~mm}$.

Quartzo: cristais fragmentados, embainhados ou com bordas arredondadas. Em alguns ainda é possível definir suas formas hexagonais. Fenocristais poiquilíticos (de até $5 \mathrm{~mm}$ ), também de forma hexagonal, englobam pequenos cristais intercrescidos (ou constituindo aglomerados) de plg e também bt;

Plagioclásio: estão fragmentados ou intensamente fraturados, principalmente os cristais maiores. Não apresentam muito zoneamento e nem inclusões. Alguns cristais apresentam texturas de dissolução acompanhando o zoneamento e também núcleos corroídos (textura esponjosa), seguido por novo crescimento do cristal. Também apresenta concentrações de inclusões fluídas acompanhando a borda de alguns cristais. Suas bordas também podem apresentar-se angulosas e/ou corroídas. Muitos estão intercrescidos com bt e opacos e apresentam cristais menores de plg;

Biotita: Apresenta-se bastante oxidada. Muitos apresentam inclusões de plg ou estão intercrescidos a estes (crescimento do plg é paralelo a clivagem da bt). Também ocorre associada aos glomérulos de plg.

Outros máficos (opx, cpx e hbl): Hbl e cpx são de difícil distinção, alguns cristais apresentam grossas bordas de oxidação de coloração avermelhada e apenas seu núcleo ainda está preservado. O opx apresenta bordas de oxidação e poucas inclusões de plg e opacos. Alguns cristais têm feições de dissolubilidade interna ou externa (arredondados/xenomórficos). Podem, além do mais, formar aglomerados (de até $2 \mathrm{~mm}$ ) ou estarem englobados por plg ou também por qtz.

Opacos: ocorrem como minerais avermelhadas. Mineral ainda não identificado.

PUL 37a

Ponto: 23 - UFRI

\section{Descrição Macroscópica}

Pequena amostra de fragmento lítico de cor cinza escuro e rosado presente como bloco no afloramento. Este lítico apresenta uma notável orientação interna, com minerais estirados e achatamento de prováveis vesículas. Estas vesículas estão parcialmente preenchidas com plg. A matriz desta rocha apresenta uma maior vesicularidade (também parcialmente preenchidas). Observa-se a presença de minerais máficos oxidados (bt e talvez hbl) e grandes fenocristais de plg. O lítico apresenta uma borda de coloração mais avermelhada no contato com a matriz.

\section{Descrição Microscópica}

Traquíto andesíto, com cristais ineqüigranulares de plg e placas de bt acompanhando uma direção de fluxo preferencial. Seguindo a mesma direção também ocorrem aglomerados de plg e bt associados a concentrações de cristais de opx. Há também pequenas lentes que se diferenciam por apresentarem texturas de desvitrificação do tipo esferulítica e axial. Na borda do lítico em contato com a matriz ocorre delgada lâmina em que se observam aglomerados de máficos com plg, assim como fenocristais de plg e bt e textura de desvitrificação com formação de esferulitos 
completos e parciais (como se fosse um púmice englobando o lítico). Na matriz, próximo ao contato, observa-se púmices menores soldados em fiammes.

\section{PUL 37E}

Ponto: 23 - UFRI

\section{Descrição Macroscópica}

Amostra de matriz do ignimbrito com lapilli-púmice branco acinzentado. A matriz da rocha apresenta uma coloração rosada de granulação afanítica, com cristaloclastos e pequenos púmices na fração lapilli-cinza menores que $2,0 \mathrm{~mm}$ e da mesma coloração do fragmento maior. O lapilli-púmice apresenta bastante vesicularidade e fenocristais de qtz, plg e bt já oxidada. Aparentemente as vesículas não estão preenchidas.

\section{Descrição Microscópica}

Amostra de matriz com lapilli-púmice. A matriz apresenta textura eutaxítica devido a um moderado a alto grau de soldamento que ocorreu no depósito e foi fortemente afetada por alteração fase-vapor. Nota-se que todos os minerais se acomodam acompanhando o soldamento dos púmices.

Quartzo: cristais fragmentados, embainhados ou com bordas arredondadas, sendo possível definir suas formas hexagonais. Fenocristais poiquilíticos, alguns com formas hexagonais, que englobam pequenos aglomerados de plagioclásio e também biotita.

Plagioclásio: fragmentados ou intensamente fraturados, principalmente os cristais maiores. Apresentam zoneamento simples ou irregular e complexo. Podem ocorrer texturas de dissolução interna associada ao zoneamento. Diversos cristais apresentam inclusões fluídas e texturas de dissolução acompanhando o zoneamento e também núcleos corroídos (textura esponjosa), seguido por novo crescimento do cristal. Também apresenta concentrações de inclusões fluídas acompanhando a borda de alguns cristais. Suas bordas também podem apresentar-se angulosas e/ou corroídas, estando por vezes embainhada. Muitos estão intercrescidos com bt e opacos e apresentam inclusões de microcristais de plg;

Biotita: Apresenta-se bastante oxidada. Muitos apresentam inclusões de plg ou estão intercrescidos a estes (crescimento do plg é paralelo à clivagem da bt). Também ocorre associada aos glomérulos de plg.

Outros máficos (opx, cpx e hbl): Hbl ocorre como microcristais euédricos $(<0,2 \mathrm{~mm})$. Opx é o mais abundante e ocorre como pequenos grãos e com finas bordas de oxidação e raras inclusões de plg e opacos. Alguns cristais apresentam feições de dissolubilidade interna ou externa (arredondados/xenomórficos). Cpx é de difícil distinção, alguns cristais apresentam grossas bordas de oxidação.

Opacos: ocorrem como minerais avermelhadas, aparente mgn. É nítido que alguns dos opacos presentes são resultantes da desagregação ou alteração de minerais máficos (bt, hbl ou px).

PUL 37F

Ponto: 23 - UFRI

Descrição Macroscópica 
Amostra de matriz do ignimbrito com lapilli-púmice rosa-avermelhado. A matriz da rocha apresenta uma coloração rosada e granulometria na fração cinza (afanítica), com cristaloclastos e pequenos púmices, branco e rosa-escuro, nas frações lapillicinza e um pequeno fragmento de provável rocha lítica. O lapilli-púmice rosaavermelhado está soldado e apresenta bastante vesicularidade. Tanto as vesículas como os aglomerados de plg e qtz se acomodam "amassados" segundo a direção de achatamento do púmice (soldamento), formando fiammes ou sigmóides. Fenocristais de bt, oxidados, também acompanham a direção de soldamento. Na matriz ocorre um grande cristaloclasto de qtz bipiramidal.

\section{Descrição Microscópica}

$\mathrm{Na}$ amostra se observa uma intercalação da matriz do ignimbrito com fragmentos de púmice soldados. É interessante observar as variações de desvitrificação de púmices e do grau de soldamento. O contato entre púmices e matriz não é muito claro, pois o púmice mescla-se a matriz e apresenta terminações em chama. A matriz apresenta um aspecto mais sujo e textura eutaxítica. Os púmices apresentam textura de desvitrificação do tipo esferulitica e axial que se corta no contato com a matriz. Dentro do púmice identificam-se vesículas vazias (13\%) compactadas com bordas de desvitrificação axial (lithophysaes). Observa-se também parte do fragmento lítico vermelho soldado em fiamme que parece tratar-se de um fragmento de tufo extremamente soldado. Este fragmento apresenta um bandamento, com alta concentração de pequenos cristais de plg e qtz, sendo que na banda mais externa de coloração mais avermelhada ocorrem concentrações maiores de opacos, px (com bordas avançadas de oxidação) e bt.

PUL 37LC

Ponto: 23 - UFRI

\section{Descrição Macroscópica}

Amostra de fragmento lítico vermelho e matriz do ignimbrito. A matriz é de coloração rosa escura e bastante porosa, apresentando cristaloclastos máficos, como bt e px e também félsicos, como qtz e plg. O fragmento lítico comporta-se como um púmice, apresentando terminações e bordas em chama, difundindo-se um pouco a matriz. Apresenta inclusões de fragmentos líticos vermelhos, além de pequenas vesículas preenchidas e estiradas, bandamento de diferentes cores (laranja, vermelho e preto, além da própria matriz da rocha) e cristais de plg e bt.

\section{Descrição Microscópica}

A matriz do ignimbrito apresenta uma textura eutaxítica e sinais de alteração fasevapor e desvitrificação do tipo esferulítica. O fragmento lítico trata-se de uma rocha piroclástica soldada e oxidada, provavelmente um lapilli-tufo ou rocha epiclástica, devido a sua fina granulometria e boa seleção dos cristaloclastos. Apresenta fragmentos dispersos de púmice em fiamme, com pequenos cristais euédricos de opx inclusos, além de qtz, plg e hbl.

\section{PUL 38A}

Bt: biotita; Cpx: clinopiroxênio; Hbl:hornblenda; Ilm: Ilmenita; Mgn: magnetita; Opx: ortopiroxênio; Plg: plagioclásio; Qtz: quartzo; 
Ponto: 24 - UFRI

\section{Descrição Microscópica}

Amostra de matriz da rocha com lítico ou púmice. Matriz desvitrificada e afetada por alteração fase-vapor, com preenchimento parcial de vesículas. Apresenta qtz $(<10 \%)$, plg $(40-50 \%)$, bt $(20-25 \%)$, opx (15\%), hbl (<8\%) e óxidos $(10 \%)$. O fragmento de coloração cinza escuro parece ser um lapilli-púmice, porém não se descarta a possibilidade de que seja uma lava. Sua matriz apresenta desvitrificação do tipo esferulítica com granulação muito fina e sua assembléia mineraógica está representada por grãos de opx euédricos a subédricos (20-25\%), plg e opx intercrescidos, fenocristais de plg com textura esponjosa, zonados e com muitas inclusões fluídas $(40 \%)$ e bt, por vezes manteada por plg, $(<10 \%)$, hbl $(<4 \%)$ e qtz $(12 \%)$.

\section{PUL 38E}

Ponto: 24 - UFRI

\section{Descrição Macroscópica}

Amostra de fragmento de rocha lítica de origem plutônica (granulação fanerítica) e composição granodiorítica. Parece apresentar a mesma assembléia mineralógica das demais rochas piroclásticas constituintes do $\mathrm{C}^{\circ}$ Pululus.

\section{Descrição Microscópica}

Rocha de composição granodiorítica, constituída por plg (50-55\%), cpx (5-8\%), bt (18$20 \%)$, opacos ( $<10 \%)$ e qtz $(15-20 \%)$. A bt e o plg são os únicos minerais que ocorrem em formas euédricas a subédricas. Os cristais de plg ocorrem com zoneamento irregular e extinção ondulante. $\mathrm{O}$ qtz ocorre como pequenos grãos irregulares ou preenchendo vazios como cristais poiquilíticos que englobam pequenos cristais de plg.

\section{PUL 39}

Ponto: 29 - UFRS

\section{Descrição Macroscópica}

Amostra da matriz ignimbrítica com lapilli-púmice. A matriz apresenta uma coloração roxo-acinzentada e cristaloclastos de plg, qtz e minerais máficos oxidados (bt, px, hbl). Pequenos fragmentos de púmice $(<2 \mathrm{~mm})$ também fazem parte da matriz e podem estar achatados, em fiamme ou arredondados. Apresentam uma coloração rosaacinzentada, sendo mais claro que a matriz. O lapilli-púmice também apresenta uma coloração rosa sendo que é possível visualizar com maior facilidade suas vesículas parcialmente preenchidas por produtos de alteração o que lhe confere uma cor amarela assim como diversos fenocristais de plg, qtz, bt e px. Todos os fragmentos de púmice apresentam finas bordas de coloração cinza-chumbo.

\section{Descrição Macroscópica}

Amostra de matriz com lapilli-púmice. A matriz apresenta textura eutaxítica, evidenciada principalmente pelos minerais que acompanham a direção de achatamento e se amoldam ao lapilli-púmice. Também é possível identificar glass- 
shards desvitrificados e deformados, dispersos na matriz. O lapilli-púmice está soldado apresentando bordas difusas e terminações em chama, além de uma textura de desvitrificação do tipo esferulítica e microgranofírica.

Quartzo: cristais fragmentados, embainhados ou com bordas arredondadas (ocorrendo como gotas), sendo possível em alguns cristais reconhecer suas formas hexagonais $(1,2 \mathrm{~mm})$. Fenocristais poiquilíticos $(<2,5 \mathrm{~mm})$, alguns hexagonais, englobam pequenos aglomerados de plg e também bt.

Plagioclásio: fragmentados ou intensamente fraturados, principalmente os cristais maiores, que podem chegar a $2,5 \mathrm{~mm}$. Apresentam zoneamento, com ou sem texturas de dissolução interna, associadas a um zoneamento irregular e complexo. Poucos cristais apresentam inclusões e também núcleos corroídos (textura esponjosa). Alguns também apresentam bordas angulosas e/ou onduladas. Muitos estão intercrescidos com bt, opx e opacos e apresentam inclusões de pequenos cristais de plg.

Biotita: Apresenta-se bastante oxidada, com inclusões de plagioclásio ou estão intercrescidos a estes (crescimento do plg é paralelo à clivagem da bt).

Outros máficos (opx, cpx e hbl): opx ocorre como pequenos grãos euédrico a subédrico, com finas bordas de oxidação e por vezes intercrescido ao plagioclásio e opacos.

\section{PUL 40C}

Ponto: 30 - UFRS

\section{Descrição Microscópica}

Amostra de matriz com lapilli-púmice. Ignimbrito soldado e reomorfizado, afetado por alteração fase-vapor e devitrificação. O reomorfismo está evidenciado pelos púmices e minerais em sigmóides, observando-se também minerais (como cristais de qtz e px), rotacionados e circundados por cristais mais alongados (como plg e bt). Os púmices estão desvitrificados e apresentam cristais maiores e menos fraturados que na matriz do ignimbrito, constituído principalmente de qtz bipiramidal, felds, bt e px. Há púmices que apresentam uma grande concentração de cristais de opx. Ocorre também um pequeno aglomerado de plg e bt, que já está, porém, afetado pela alteração. As vesículas do púmice estão preenchidas por felds e qtz (devido à alteração fase-vapor).

PUL 42

Ponto: 30 - UFRS

Amostra da matriz do ignimbrito. Ignimbrito soldado e reomorfizado, afetado por alteração fase-vapor e devitrificação.

O reomorfismo está evidenciando pelos púmices e minerais em sigmóides. Observase também minerais, como qtz, plg e px, rotacionados e circundados por placas alongadas, de plg e bt. Os púmices de estão desvitrificados e apresentam cristais maiores e menos fraturados que a matriz, e estão constituídos por qtz bipiramidal, plg, bt e px. Há púmices que apresentam uma grande concentração de cristais de opx. Ocorre também um pequeno aglomerado de plg e bt, que já está, porémm bem Bt: biotita; Cpx: clinopiroxênio; Hbl:hornblenda; Ilm: Ilmenita; Mgn: magnetita; Opx: ortopiroxênio; Plg: plagioclásio; Qtz: quartzo; 
afetada por alteração. As vesículas de púmice estão preenchidas por plg e qtz (associado ao processo de alteração fase-vapor).

\section{PUL 44A}

Ponto: 44 - UFRS

Amostra de lapilli-púmice branco. A matriz do púmice exibe textura perlítica com esferulitos disseminados. O qtz $(25 \%)$ já está bastante reabsorvido e bem arredondado. Nota-se que a reação se dá principalmente em contato com o vidro da matriz. Cristais de plg (40\%) também apresentam bordas de reabsorção (principalmente em contato com o vidro), que afeta também o seu zoneamento (com extinção ondulante). A textura esponjosa ocorre zonalmente no mineral, além de também ocorrerem concentrações de inclusões fluídas.

A biotita $(20 \%)$ está bastante fresca e pode ocorrer como cristais poiquiliticos englobando grãos anédricos de plg ou apresentando bordas de reação, que cristaliza um fino agregado constituído por plg e opacos. Também ocorrem opx (como cristais euédricos a sub-édricos $<1 \mathrm{~mm})$, hbl (<1\%), „apatita, \pm zircão, \pm mgn, \pm ilm.

\section{PUL 44B}

Ponto: 44 - UFRS

Amostra de lapilli-púmice de cor cinza escuro. Púmice que apresenta uma devitrificação bastante avançada (microgranofírica), sem esferulitos bem definidos e com cristalização fase-vapor preenchendo espaços irregulares e, outrora, vazios. O plagioclásio está orientado, o que se assemelha a uma textura típica de lava, apresentando também uma grande concentração de minerais máficos, como opx, hbl, bt e óxidos avermelhados. O plagioclásio (labradorita) ocorre intercrescido aos grãos de opx e ilmenita ou formando glomérulos com estes minerais (que exibem formas euédricas). Fenocristais de plg apresentam uma textura em peneira, semelhante a vesículas, que ocorrem associadas ao zoneamento do mineral. A principal diferença entre o púmice e a matriz é a porcentagem de qtz, que varia de 6 a $20 \%$, respectivamente. Os demais minerais apresentam concentrações de 35-40\% plg, 20$25 \% \mathrm{bt},<10 \%$ opx $,<5 \% \mathrm{cpx},<5 \% \mathrm{hbl},<3 \%$ opacos.

\section{PUL 44C}

Ponto: 44 - UFRS

Amostra da matriz da rocha e púmice rosa. Ignimbrito desvitrificado com soldamento incipiente. A matriz apresenta-se bastante alterada, um pouco afetada por serecitização. No púmice pode-se observar uma desvitrificação avançada (textura microgranofírica), com a formação de esferulitos. A porcentagem de cristaloclastos varia de $40 \%$ para a matriz e de $20-25 \%$ para os púmices. Há uma notável diferença entre o púmice e a matriz, no qual o púmice se assembléia muito a uma lava dacítica, apresentando microcristais e agregados de minerais máficos com plagioclásio que acompanham uma direção preferencial (talvez devido ao soldamento). Este púmice sta constituído por cristais de labradorita (30-40\%), opx (15\%), cpx (<8\%), bt (<20\%), qtz embainhado (<8\%) e hbl (<4\%). A matriz está constituída por $30-40 \%$ de fenocristais 
de labradorita- andesina, opx, bt, qtz e cpx. O qtz ocorre bastante embainhado, o plg exibe uma textura esponjosa associada ao zoneamento e a bt está bordejada por um agregado de finos prismas de opx, além de plg e opacos.

\section{PUL 44D}

Ponto: 44 - UFRS

Amostra de matriz ad rocha e púmice cinza. Púmice raro, com desvitrificação avançada e riqueza em minerais máficos. Apresenta texturas interessantes. Ocorrem inclusões de plg em cristais de opx e bt, e os três podem ocorrem associados em um fino agregado. Cristais de plg apresentam zoneamento irregular e texturas de reabsorção que também afetam o zoneamento. Os fenocristais do mesmo mineral também apresentam uma textura em peneira bastante avançada, associada também ao zoneamento. Há porções dentro do púmice representadas por concentrações de minerais máficos e óxidos (com pouco qtz). Ao todo a rocha apresenta $20-25 \%$ de qtz, $40 \%$ de labradorita- andesina, $20 \%$ de bt, $12 \%$ de opx, $6 \%$ de cpx e $<4 \%$ de hbl.

Bt: biotita; Cpx: clinopiroxênio; Hbl:hornblenda; Ilm: Ilmenita; Mgn: magnetita; Opx: ortopiroxênio; Plg: plagioclásio; Qtz: quartzo; 
ANEXO V - Tabelas 1.

\section{Análise química dos plagioclásios}

UFC

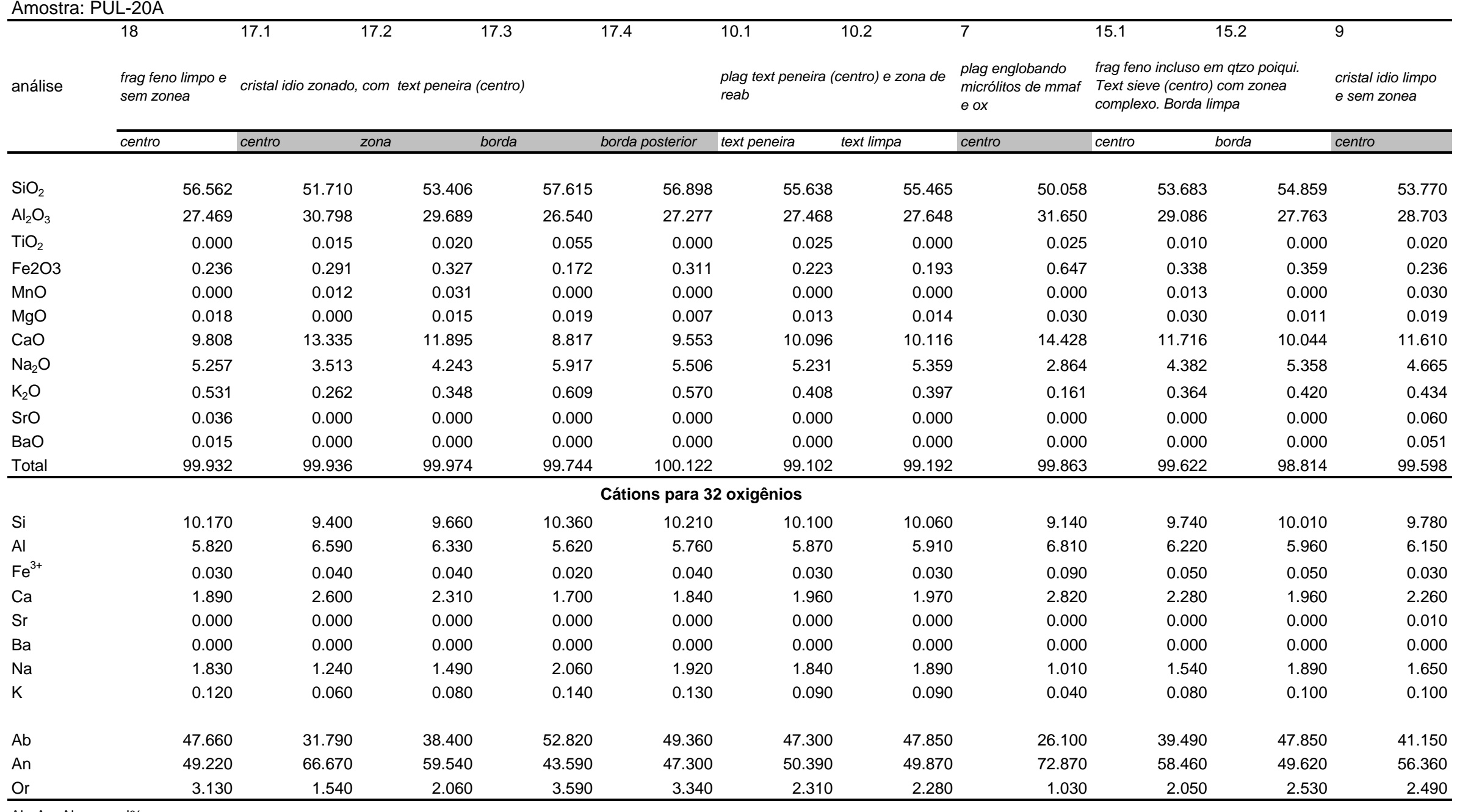

$\mathrm{Ab}, \mathrm{An}, \mathrm{Ab}$ em mol\%

mfeno: microfenocristais; feno: fenocristais; plag: plagioclásio; idio: idiomórfico; zonea: zoneamento; text; textura; reab: reabsorção; mmaf: minerais máficos; ox: óxidos; qtz: quartzo; poiqui: poiquilítico; gde: grande; irreg: irregular 
ANEXO V - Tabelas 1.

\section{Análise química dos plagioclásios}

UFC

Amostra: PUL-20A 11.1

$$
11.2
$$
8.1 8.2

análise cristal idio com forte clivagem albitica e borda posterior

plag idio com suave zonea e clivagem sobreposta

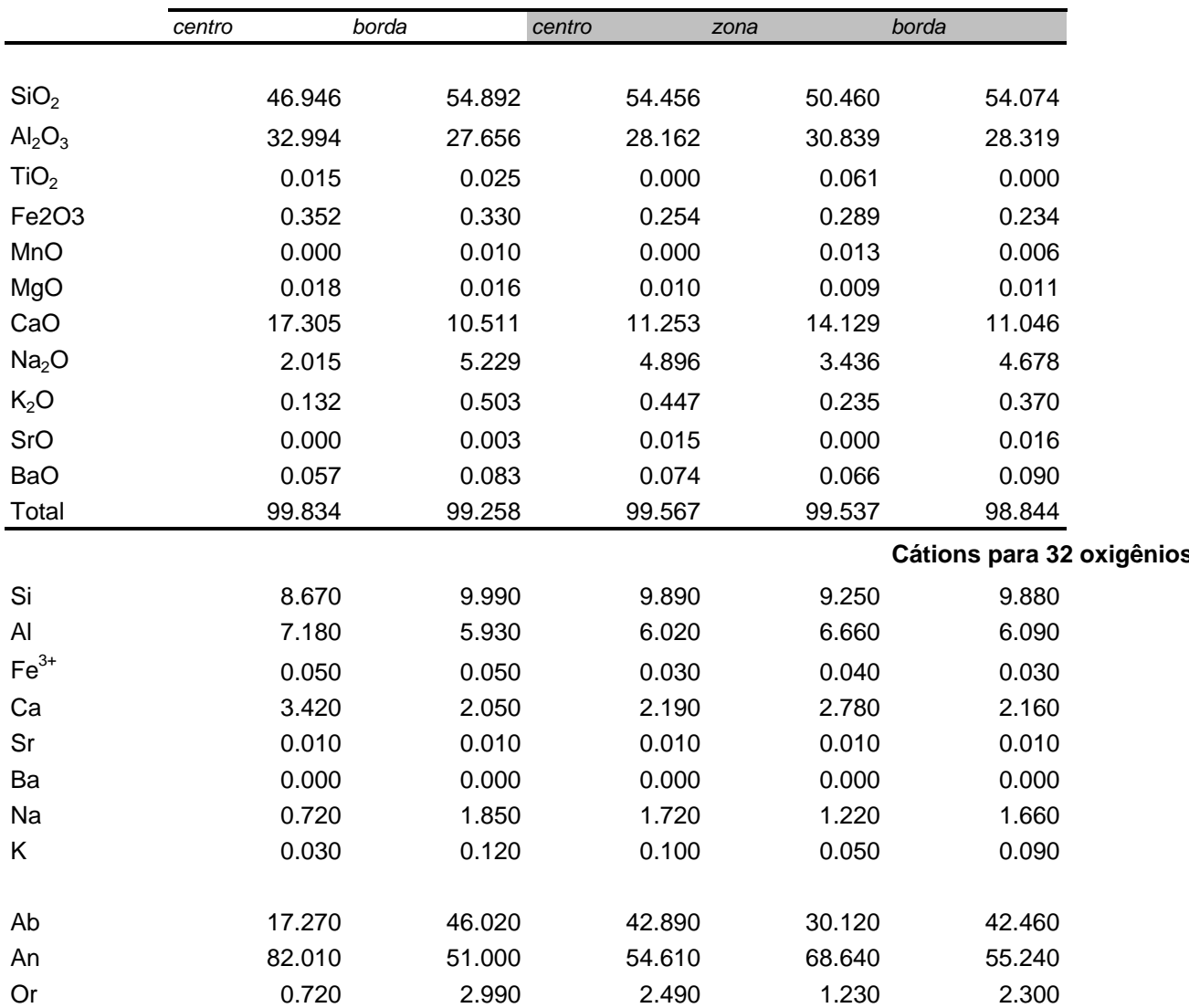

Ab, An, Ab em mol\%
UFRI

Amostra: PUL-38A

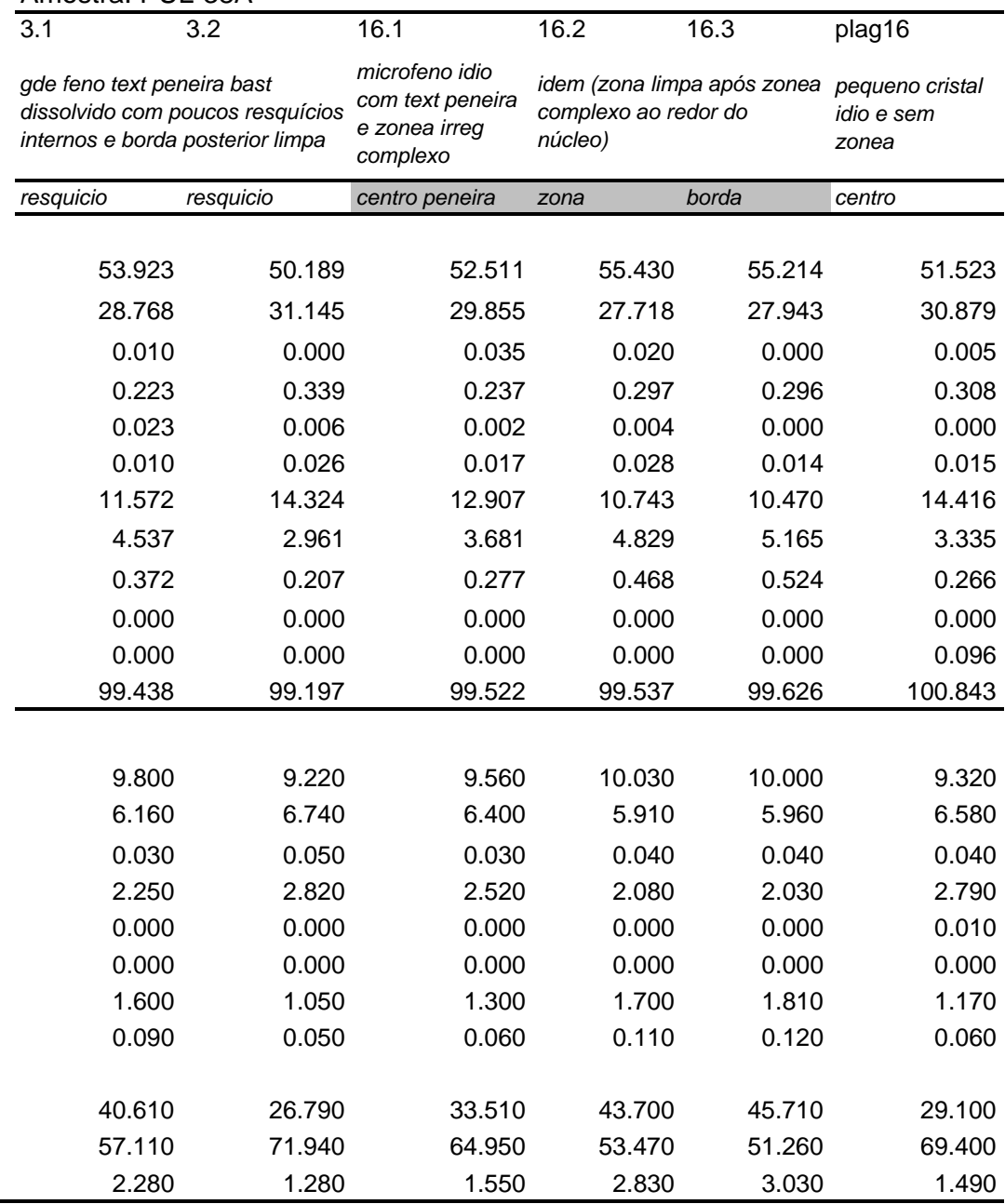

mfeno: microfenocristais; feno: fenocristais; plag: plagioclásio; idio: idiomórfico; zonea: zoneamento; text; textura; reab: reabsorção; mmaf: minerais máficos; ox: óxidos; qtz: quartzo; poiqui: poiquilítico; gde: grande; irreg: irregular 
ANEXO V - Tabelas 1.

Análise química dos plagioclásios

UFRI

Amostra: PUL-38A

\begin{tabular}{|c|c|c|c|c|c|c|c|c|c|c|c|c|c|}
\hline \multirow{3}{*}{ análise } & 12.1 & 12.2 & 19.1 & 19.2 & 19.3 & 19.4 & 19.5 & 19.6 & 19.7 & 14.1 & 14.2 & 14.3 & 4.4 \\
\hline & \multicolumn{2}{|c|}{$\begin{array}{l}\text { frag de grande feno sub-idio } \\
\text { com text peneira no centro e } \\
\text { em zona. Bordas } \\
\text { arredondadas }\end{array}$} & $\begin{array}{l}\text { feno com zonea } \\
\text { simples e bordas } \\
\text { parcial/e reabsorv. }\end{array}$ & $\begin{array}{l}\text { idem (zona } \\
\text { sombreada) }\end{array}$ & $\begin{array}{l}\text { idem (zona } \\
\text { clara) }\end{array}$ & $\begin{array}{l}\text { idem (zona } \\
\text { sombreada) }\end{array}$ & $\begin{array}{l}\text { idem (fina e } \\
\text { discreta zona } \\
\text { clara entre } \\
\text { sombreada) }\end{array}$ & $\begin{array}{l}\text { idem (zona } \\
\text { sombreada } \\
\text { irregular) }\end{array}$ & $\begin{array}{l}\text { idem (fina } \\
\text { borda branca } \\
\text { posterior) }\end{array}$ & \multicolumn{4}{|c|}{ gde feno sub-idio c/ zonea simples } \\
\hline & centro & borda & centro & zona & zona & zona & zona & zona & borda & centro & zona & zona & ona \\
\hline $\mathrm{SiO}_{2}$ & 48.691 & 52.758 & 49.418 & 47.529 & 50.876 & 47.158 & 50.922 & 50.321 & 53.461 & 46.136 & 46.450 & 48.202 & 47.722 \\
\hline $\mathrm{Al}_{2} \mathrm{O}_{3}$ & 31.978 & 29.903 & 31.559 & 33.000 & 30.948 & 32.581 & 30.709 & 30.763 & 28.077 & 33.618 & 33.856 & 32.457 & 33.350 \\
\hline $\mathrm{TiO}_{2}$ & 0.015 & 0.000 & 0.020 & 0.000 & 0.000 & 0.000 & 0.005 & 0.000 & 0.025 & 0.000 & 0.045 & 0.060 & 0.010 \\
\hline $\mathrm{Fe} 2 \mathrm{O} 3$ & 0.349 & 0.320 & 0.414 & 0.304 & 0.266 & 0.283 & 0.277 & 0.216 & 0.283 & 0.240 & 0.351 & 0.531 & 0.478 \\
\hline $\mathrm{MnO}$ & 0.000 & 0.000 & 0.016 & 0.000 & 0.000 & 0.006 & 0.000 & 0.003 & 0.015 & 0.048 & 0.033 & 0.015 & 0.000 \\
\hline $\mathrm{MgO}$ & 0.070 & 0.006 & 0.107 & 0.014 & 0.016 & 0.019 & 0.027 & 0.019 & 0.042 & 0.030 & 0.017 & 0.135 & 0.004 \\
\hline $\mathrm{CaO}$ & 15.083 & 12.773 & 15.095 & 17.166 & 14.175 & 16.266 & 14.075 & 14.549 & 11.129 & 18.021 & 18.334 & 16.325 & 16.929 \\
\hline $\mathrm{Na}_{2} \mathrm{O}$ & 2.704 & 3.856 & 2.919 & 1.934 & 3.490 & 2.256 & 3.505 & 3.231 & 4.907 & 1.710 & 1.551 & 2.338 & 2.121 \\
\hline $\mathrm{K}_{2} \mathrm{O}$ & 0.241 & 0.310 & 0.282 & 0.110 & 0.333 & 0.094 & 0.226 & 0.250 & 0.552 & 0.095 & 0.078 & 0.209 & 0.151 \\
\hline SrO & 0.000 & 0.000 & 0.000 & 0.015 & 0.000 & 0.074 & 0.011 & 0.000 & 0.000 & 0.000 & 0.000 & 0.000 & 0.035 \\
\hline $\mathrm{BaO}$ & 0.000 & 0.000 & 0.063 & 0.105 & 0.060 & 0.007 & 0.058 & 0.104 & 0.055 & 0.059 & 0.016 & 0.048 & 0.074 \\
\hline Total & 99.131 & 99.926 & 99.893 & 100.177 & 100.164 & 98.744 & 99.815 & 99.456 & 98.546 & 99.957 & 100.731 & 100.320 & 100.874 \\
\hline & & & & & & Cátions para & a 32 oxigênios & & & & & & \\
\hline $\mathrm{Si}$ & 8.990 & 9.570 & 9.060 & 8.730 & 9.270 & 8.770 & 9.300 & 9.240 & 9.830 & 8.530 & 8.520 & 8.830 & 8.710 \\
\hline Al & 6.950 & 6.390 & 6.810 & 7.140 & 6.640 & 7.140 & 6.610 & 6.650 & 6.080 & 7.320 & 7.310 & 7.000 & 7.170 \\
\hline $\mathrm{Fe}^{3+}$ & 0.050 & 0.040 & 0.060 & 0.040 & 0.040 & 0.040 & 0.040 & 0.030 & 0.040 & 0.030 & 0.050 & 0.070 & 0.070 \\
\hline $\mathrm{Ca}$ & 2.980 & 2.480 & 2.970 & 3.380 & 2.770 & 3.240 & 2.750 & 2.860 & 2.190 & 3.570 & 3.600 & 3.210 & 3.310 \\
\hline Sr & 0.000 & 0.000 & 0.010 & 0.010 & 0.010 & 0.000 & 0.010 & 0.010 & 0.010 & 0.010 & 0.000 & 0.010 & 0.010 \\
\hline $\mathrm{Ba}$ & 0.000 & 0.000 & 0.000 & 0.000 & 0.000 & 0.010 & 0.000 & 0.000 & 0.000 & 0.000 & 0.000 & 0.000 & 0.000 \\
\hline $\mathrm{Na}$ & 0.970 & 1.360 & 1.040 & 0.690 & 1.230 & 0.810 & 1.240 & 1.150 & 1.750 & 0.610 & 0.550 & 0.830 & 0.750 \\
\hline K & 0.060 & 0.070 & 0.070 & 0.030 & 0.080 & 0.020 & 0.050 & 0.060 & 0.130 & 0.020 & 0.020 & 0.050 & 0.040 \\
\hline$A b$ & 24.190 & 34.780 & 25.490 & 16.830 & 30.150 & 19.900 & 30.690 & 28.260 & 43.000 & 14.520 & 13.190 & 20.290 & 18.290 \\
\hline An & 74.310 & 63.430 & 72.790 & 82.440 & 67.890 & 79.610 & 68.070 & 70.270 & 53.810 & 85.000 & 86.330 & 78.480 & 80.730 \\
\hline Or & 1.500 & 1.790 & 1.720 & 0.730 & 1.960 & 0.490 & 1.240 & 1.470 & 3.190 & 0.480 & 0.480 & 1.220 & 0.980 \\
\hline
\end{tabular}

Ab, An, Ab em mol\%

mfeno: microfenocristais; feno: fenocristais; plag: plagioclásio; idio: idiomórfico; zonea: zoneamento; text; textura; reab: reabsorção; mmaf: minerais máficos; ox: óxidos; qtz: quartzo; poiqui: poiquilítico; gde: grande; irreg: irregular 
ANEXO V - Tabelas 1.

Análise química dos plagioclásios

UFRI

Amostra: PUL-38A

14.5

20.1

20.2 20.3 20.4 20.5 20.6

análise Idem. Borda feno sub-idio com centro e zonas com text de dissol borda cemro ZOाla zona

\begin{tabular}{|c|c|c|c|c|c|c|c|c|}
\hline & borda & Eltro & & zona & & & borda & centro \\
\hline $\mathrm{SiO}_{2}$ & 49.748 & 49.056 & 47.760 & 50.414 & 54.313 & 49.028 & 51.579 & 51.075 \\
\hline $\mathrm{Al}_{2} \mathrm{O}_{3}$ & 31.348 & 32.272 & 32.188 & 31.254 & 28.697 & 32.139 & 29.571 & 30.695 \\
\hline $\mathrm{TiO}_{2}$ & 0.025 & 0.035 & 0.000 & 0.040 & 0.015 & 0.000 & 0.000 & 0.000 \\
\hline $\mathrm{Fe} 2 \mathrm{O} 3$ & 0.398 & 0.351 & 0.391 & 0.326 & 0.297 & 0.377 & 0.265 & 0.426 \\
\hline $\mathrm{MnO}$ & 0.000 & 0.006 & 0.000 & 0.000 & 0.012 & 0.025 & 0.000 & 0.000 \\
\hline MgO & 0.014 & 0.030 & 0.029 & 0.012 & 0.020 & 0.002 & 0.032 & 0.017 \\
\hline $\mathrm{CaO}$ & 15.150 & 15.726 & 15.979 & 14.992 & 11.688 & 15.577 & 13.008 & 14.246 \\
\hline $\mathrm{Na}_{2} \mathrm{O}$ & 2.903 & 2.716 & 2.529 & 3.138 & 4.865 & 2.683 & 3.938 & 3.705 \\
\hline $\mathrm{K}_{2} \mathrm{O}$ & 0.182 & 0.118 & 0.166 & 0.162 & 0.371 & 0.161 & 0.365 & 0.297 \\
\hline $\mathrm{SrO}$ & 0.020 & 0.006 & 0.048 & 0.088 & 0.000 & 0.000 & 0.076 & 0.062 \\
\hline $\mathrm{BaO}$ & 0.171 & 0.056 & 0.084 & 0.067 & 0.007 & 0.073 & 0.086 & 0.000 \\
\hline Total & 99.959 & 100.372 & 99.174 & 100.493 & 100.285 & 100.065 & 98.920 & 100.523 \\
\hline \multicolumn{9}{|c|}{ Cátions para 32 oxigênios } \\
\hline $\mathrm{Si}$ & 9.110 & 8.960 & 8.850 & 9.180 & 9.810 & 8.980 & 9.490 & 9.290 \\
\hline Al & 6.760 & 6.940 & 7.030 & 6.700 & 6.100 & 6.930 & 6.410 & 6.570 \\
\hline $\mathrm{Fe}^{3+}$ & 0.050 & 0.050 & 0.050 & 0.040 & 0.040 & 0.050 & 0.040 & 0.060 \\
\hline $\mathrm{Ca}$ & 2.970 & 3.080 & 3.170 & 2.920 & 2.260 & 3.060 & 2.570 & 2.780 \\
\hline $\mathrm{Sr}$ & 0.020 & 0.010 & 0.010 & 0.010 & 0.000 & 0.010 & 0.010 & 0.000 \\
\hline $\mathrm{Ba}$ & 0.000 & 0.000 & 0.000 & 0.010 & 0.000 & 0.000 & 0.010 & 0.000 \\
\hline $\mathrm{Na}$ & 1.030 & 0.960 & 0.910 & 1.110 & 1.700 & 0.950 & 1.410 & 1.310 \\
\hline $\mathrm{K}$ & 0.040 & 0.030 & 0.040 & 0.040 & 0.090 & 0.040 & 0.090 & 0.070 \\
\hline$A b$ & 25.500 & 23.590 & 22.090 & 27.270 & 41.980 & 23.460 & 34.640 & 31.490 \\
\hline An & 73.510 & 75.680 & 76.940 & 71.740 & 55.800 & 75.560 & 63.140 & 66.830 \\
\hline Or & 0.990 & 0.740 & 0.970 & 0.980 & 2.220 & 0.990 & 2.210 & 1.680 \\
\hline
\end{tabular}

Ab, An, Ab em mol\%
UFRS

amostra: PUL-44a

\begin{tabular}{|c|c|c|c|}
\hline 1 & 02 & 4 & 5 \\
\hline $\begin{array}{l}\text { frag de feno } \\
\text { idio com } \\
\text { zonea nas } \\
\text { bordas }\end{array}$ & & $\begin{array}{l}\text { plag intercresc } \\
\text { com bt. Sem } \\
\text { text ou zonea. } \\
\text { Incl ox }\end{array}$ & $\begin{array}{l}\text { gde feno limpo, } \\
\text { sem zonea ou } \\
\text { text fraturado }\end{array}$ \\
\hline centro & centro & centro & centro \\
\hline 55.153 & 48.629 & 56.503 & 56.557 \\
\hline 28.405 & 32.814 & 27.571 & 27.445 \\
\hline 0.000 & 0.000 & 0.000 & 0.000 \\
\hline 0.188 & 0.316 & 0.277 & 0.224 \\
\hline 0.006 & 0.029 & 0.000 & 0.000 \\
\hline 0.005 & 0.015 & 0.009 & 0.015 \\
\hline 10.685 & 15.694 & 9.960 & 9.795 \\
\hline 4.937 & 2.283 & 5.274 & 5.362 \\
\hline 0.494 & 0.136 & 0.571 & 0.616 \\
\hline 0.031 & 0.000 & 0.036 & 0.000 \\
\hline 0.075 & 0.072 & 0.050 & 0.093 \\
\hline 99.979 & 99.988 & 100.251 & 100.107 \\
\hline 9.950 & 8.900 & 10.140 & 10.160 \\
\hline 6.040 & 7.070 & 5.830 & 5.810 \\
\hline 0.030 & 0.040 & 0.040 & 0.030 \\
\hline 2.070 & 3.080 & 1.920 & 1.890 \\
\hline 0.010 & 0.010 & 0.010 & 0.010 \\
\hline 0.000 & 0.000 & 0.000 & 0.000 \\
\hline 1.730 & 0.810 & 1.840 & 1.870 \\
\hline 0.110 & 0.030 & 0.130 & 0.140 \\
\hline 44.250 & 20.660 & 47.300 & 47.950 \\
\hline 52.940 & 78.570 & 49.360 & 48.460 \\
\hline 2.810 & 0.770 & 3.340 & 3.590 \\
\hline
\end{tabular}

mfeno: microfenocristais; feno: fenocristais; plag: plagioclásio; idio: idiomórfico; zonea: zoneamento; text; textura; reab: reabsorção; mmaf: minerais máficos; ox: óxidos; qtz: quartzo; poiqui: poiquilítico; gde: grande; irreg: irregular 
ANEXO V - Tabelas 1.

Análise química dos plagioclásios

UFRS

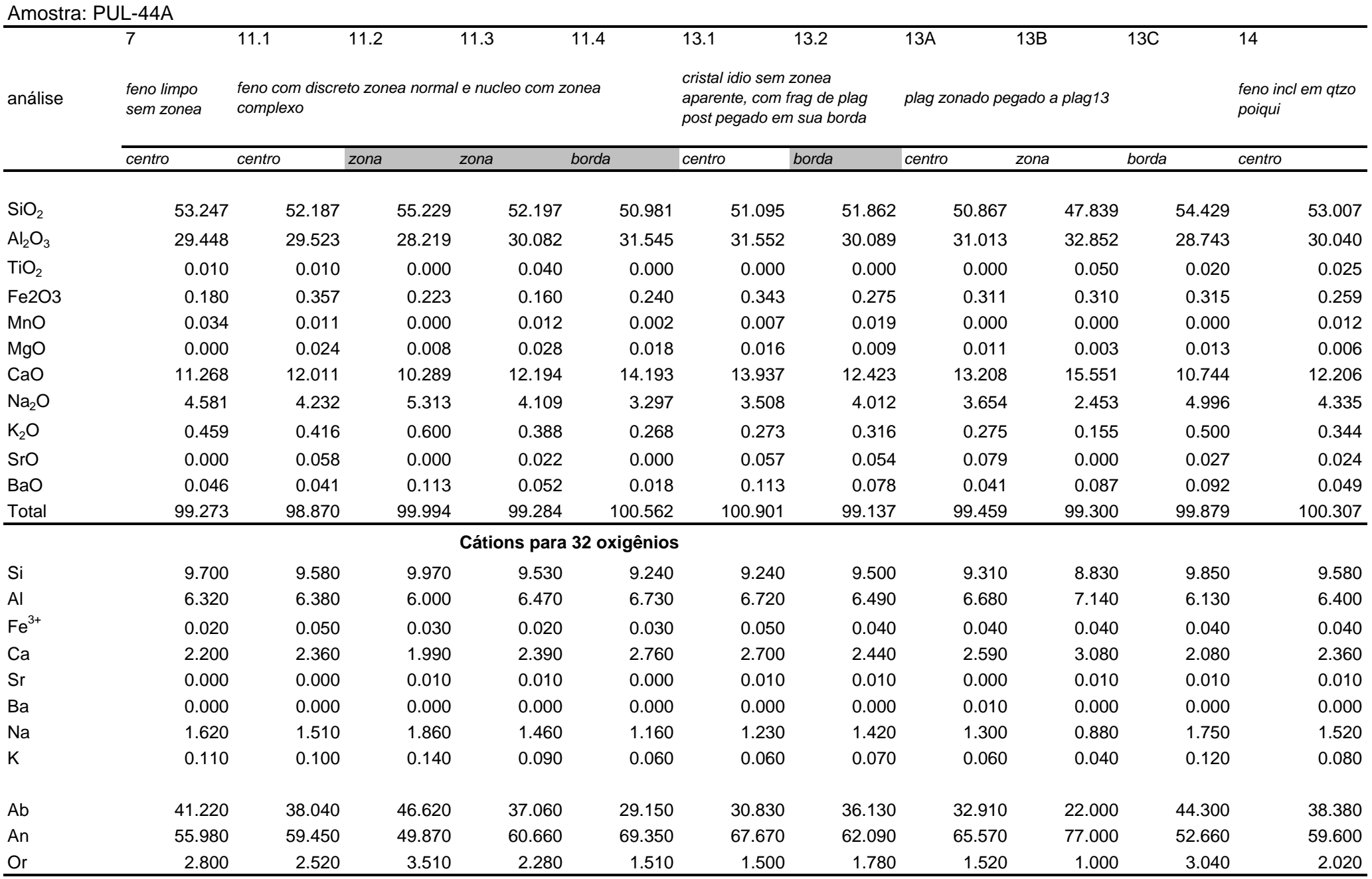

Ab, An, Ab em mol\%

mfeno: microfenocristais; feno: fenocristais; plag: plagioclásio; idio: idiomórfico; zonea: zoneamento; text; textura; reab: reabsorção; mmaf: minerais máficos; ox: óxidos; qtz: quartzo; poiqui: poiquilítico; gde: grande; irreg: irregular 
ANEXO V - Tabelas 1.

Análise química dos plagioclásios

UFRS

Amostra: PUL-44B

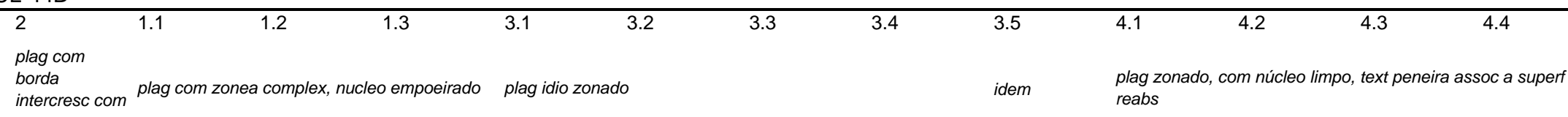

intercresc
px e ox

\begin{tabular}{|c|c|c|c|c|c|c|c|c|c|c|c|c|c|}
\hline \multirow[t]{2}{*}{ análise } & \multirow{2}{*}{$\begin{array}{l}\text { borda } \\
\text { intercresc com } \\
\text { px e ox } \\
\text { borda }\end{array}$} & \multicolumn{3}{|c|}{ plag com zonea complex, nucleo empoeirado } & \multicolumn{4}{|l|}{ plag idio zonado } & idem & \multicolumn{4}{|c|}{$\begin{array}{l}\text { plag zonado, com núcleo limpo, text peneira assoc a superf } \\
\text { reabs }\end{array}$} \\
\hline & & núcleo sujo & nucleo limpo & borda & núcleo & zona & zona & zona & borda & núcleo & zona peneira & zona reabsorv & borda \\
\hline $\mathrm{SiO}_{2}$ & 47.852 & 56.487 & 54.586 & 56.854 & 57.130 & 51.750 & 56.412 & 56.281 & 54.646 & 55.017 & 51.837 & 50.869 & 55.242 \\
\hline $\mathrm{Al}_{2} \mathrm{O}_{3}$ & 33.321 & 27.461 & 28.621 & 27.209 & 27.305 & 30.521 & 27.667 & 27.673 & 28.742 & 28.480 & 30.434 & 31.018 & 28.311 \\
\hline $\mathrm{TiO}_{2}$ & 0.099 & 0.030 & 0.000 & 0.025 & 0.025 & 0.020 & 0.000 & 0.020 & 0.010 & 0.025 & 0.000 & 0.054 & 0.020 \\
\hline $\mathrm{Fe} 2 \mathrm{O} 3$ & 0.631 & 0.208 & 0.208 & 0.172 & 0.241 & 0.324 & 0.179 & 0.253 & 0.262 & 0.228 & 0.308 & 0.285 & 0.247 \\
\hline $\mathrm{MnO}$ & 0.013 & 0.000 & 0.000 & 0.002 & 0.006 & 0.005 & 0.019 & 0.023 & 0.000 & 0.011 & 0.000 & 0.000 & 0.012 \\
\hline $\mathrm{MgO}$ & 0.029 & 0.014 & 0.018 & 0.014 & 0.015 & 0.008 & 0.022 & 0.010 & 0.012 & 0.001 & 0.022 & 0.006 & 0.016 \\
\hline $\mathrm{CaO}$ & 16.583 & 9.854 & 11.228 & 10.108 & 9.695 & 13.545 & 10.037 & 10.277 & 11.475 & 11.199 & 13.233 & 13.751 & 10.951 \\
\hline $\mathrm{Na}_{2} \mathrm{O}$ & 2.052 & 5.501 & 4.837 & 5.425 & 5.491 & 3.503 & 5.389 & 5.128 & 4.595 & 4.689 & 3.729 & 3.344 & 4.771 \\
\hline $\mathrm{K}_{2} \mathrm{O}$ & 0.124 & 0.582 & 0.450 & 0.615 & 0.610 & 0.276 & 0.600 & 0.540 & 0.423 & 0.454 & 0.268 & 0.266 & 0.498 \\
\hline SrO & 0.000 & 0.000 & 0.000 & 0.000 & 0.000 & 0.000 & 0.000 & 0.000 & 0.000 & 0.000 & 0.000 & 0.000 & 0.000 \\
\hline $\mathrm{BaO}$ & 0.000 & 0.000 & 0.000 & 0.000 & 0.000 & 0.000 & 0.000 & 0.000 & 0.000 & 0.000 & 0.000 & 0.000 & 0.000 \\
\hline Total & 100.704 & 100.137 & 99.948 & 100.424 & 100.518 & 99.952 & 100.325 & 100.205 & 100.165 & 100.104 & 99.831 & 99.593 & 100.068 \\
\hline \multicolumn{14}{|c|}{ Cátions para 32 oxigênios } \\
\hline Si & 8.730 & 10.150 & 9.870 & 10.190 & 10.210 & 9.410 & 10.120 & 10.110 & 9.850 & 9.920 & 9.430 & 9.290 & 9.960 \\
\hline Al & 7.160 & 5.810 & 6.090 & 5.740 & 5.750 & 6.540 & 5.850 & 5.850 & 6.100 & 6.050 & 6.520 & 6.670 & 6.010 \\
\hline $\mathrm{Fe}^{3+}$ & 0.090 & 0.030 & 0.030 & 0.020 & 0.030 & 0.040 & 0.020 & 0.030 & 0.040 & 0.030 & 0.040 & 0.040 & 0.030 \\
\hline $\mathrm{Ca}$ & 3.240 & 1.900 & 2.170 & 1.940 & 1.860 & 2.640 & 1.930 & 1.980 & 2.220 & 2.160 & 2.580 & 2.690 & 2.110 \\
\hline $\mathrm{Sr}$ & 0.000 & 0.000 & 0.000 & 0.000 & 0.000 & 0.000 & 0.000 & 0.000 & 0.000 & 0.000 & 0.000 & 0.000 & 0.000 \\
\hline $\mathrm{Ba}$ & 0.000 & 0.000 & 0.000 & 0.000 & 0.000 & 0.000 & 0.000 & 0.000 & 0.000 & 0.000 & 0.000 & 0.000 & 0.000 \\
\hline $\mathrm{Na}$ & 0.730 & 1.920 & 1.700 & 1.890 & 1.900 & 1.240 & 1.870 & 1.790 & 1.610 & 1.640 & 1.320 & 1.180 & 1.670 \\
\hline $\mathrm{K}$ & 0.030 & 0.130 & 0.100 & 0.140 & 0.140 & 0.060 & 0.140 & 0.120 & 0.100 & 0.100 & 0.060 & 0.060 & 0.110 \\
\hline$A b$ & 18.250 & 48.610 & 42.820 & 47.610 & 48.720 & 31.470 & 47.460 & 46.020 & 40.970 & 42.050 & 33.330 & 30.030 & 42.930 \\
\hline An & 81.000 & 48.100 & 54.660 & 48.870 & 47.690 & 67.010 & 48.980 & 50.900 & 56.490 & 55.380 & 65.150 & 68.450 & 54.240 \\
\hline Or & 0.750 & 3.290 & 2.520 & 3.530 & 3.590 & 1.520 & 3.550 & 3.080 & 2.540 & 2.560 & 1.520 & 1.530 & 2.830 \\
\hline
\end{tabular}

Ab, An, Ab em mol\%

mfeno: microfenocristais; feno: fenocristais; plag: plagioclásio; idio: idiomórfico; zonea: zoneamento; text; textura; reab: reabsorção; mmaf: minerais máficos; ox: óxidos; qtz: quartzo; poiqui: poiquilítico; gde: grande; irreg: irregular 
ANEXO V - Tabelas 1.

Análise química dos plagioclásios

UFRS

Amostra: PUL-44C 56.1 6.1 plag intercresc parcial/e reab. compx. Text Zonado. Text $\begin{array}{ll}\text { Zonado. Text } & \text { peneiral } \\ \text { peneira núcleo e } & \text { empoeirado) }\end{array}$ \begin{tabular}{ll} 
& borda limpa \\
\hline núcleo & núcleo(limpo)
\end{tabular}

6.2
empoeirado)

núcleo

\section{$\mathrm{SiO}_{2}$}

$\mathrm{Al}_{2} \mathrm{O}_{3}$

$\mathrm{TiO}_{2}$

$\mathrm{Fe} 2 \mathrm{O} 3$

$\mathrm{MnO}$

$\mathrm{MgO}$

$\mathrm{CaO}$

$\mathrm{Na}_{2} \mathrm{O}$

$\mathrm{Ka}_{2} \mathrm{O}$

$\mathrm{SrO}$

$\mathrm{BaO}$

Total

8.62

$\mathrm{Fe}^{3+} \quad 0.06$

$\begin{array}{ll}\mathrm{Ca} & 3.400 \\ \mathrm{Sr} & 0.000\end{array}$

$\mathrm{Sr}$

$\mathrm{Na} \quad 0.600$

K

$\begin{array}{lr}\mathrm{Ab} & 14.930 \\ \mathrm{An} & 84.580 \\ \mathrm{Or} & 0.500\end{array}$

Ab, An, Ab em mol\% amostra: PUL-44C

\begin{tabular}{|c|c|c|}
\hline \multicolumn{2}{|c|}{$\begin{array}{l}\text { peq cristal sub-idio (bordas } \\
\text { quebradas), zonado }\end{array}$} & $\begin{array}{l}2.1 \\
\text { cristal frat c/ text } \\
\text { peneira no } \\
\text { núcleo. Borda } \\
\text { limpa }\end{array}$ \\
\hline núcleo & borda & núcelo \\
\hline 56.780 & 56.011 & 55.316 \\
\hline 27.793 & 27.559 & 28.871 \\
\hline 0.050 & 0.035 & 0.020 \\
\hline 0.307 & 0.275 & 0.272 \\
\hline 0.000 & 0.011 & 0.000 \\
\hline 0.014 & 0.023 & 0.011 \\
\hline 9.894 & 9.966 & 13.555 \\
\hline 5.174 & 5.232 & 2.429 \\
\hline 0.571 & 0.599 & 0.137 \\
\hline 0.000 & 0.000 & 0.000 \\
\hline 0.000 & 0.000 & 0.000 \\
\hline 100.583 & 99.711 & 100.611 \\
\hline 10.140 & 10.110 & 9.890 \\
\hline 5.850 & 5.860 & 6.080 \\
\hline 0.040 & 0.040 & 0.040 \\
\hline 1.890 & 1.930 & 2.600 \\
\hline 0.000 & 0.000 & 0.000 \\
\hline 0.000 & 0.000 & 0.000 \\
\hline 1.790 & 1.830 & 0.840 \\
\hline 0.130 & 0.140 & 0.030 \\
\hline 46.980 & 46.920 & 24.210 \\
\hline 49.610 & 49.490 & 74.930 \\
\hline 3.410 & 3.590 & 0.860 \\
\hline
\end{tabular}

0.860

mfeno: microfenocristais; feno: fenocristais; plag: plagioclásio; idio: idiomórfico; zonea: zoneamento; text; textura; reab: reabsorção; mmaf: minerais máficos; ox: óxidos; qtz: quartzo; poiqui: poiquilítico; gde: grande; irreg: irregular 
ANEXO V - Tabelas 1.

Análise química dos plagioclásios

UFRS

Amostra: PUL-44C $2.2 \quad 3.1$ 3.2 .1 4.2 4.3 4.4 5.1 cristal c/ núcleo parcial/e análise idem. Borda feno c/ text intensa no núcleo. plag com núcleo sujo e zonea idem idem borda núcleo

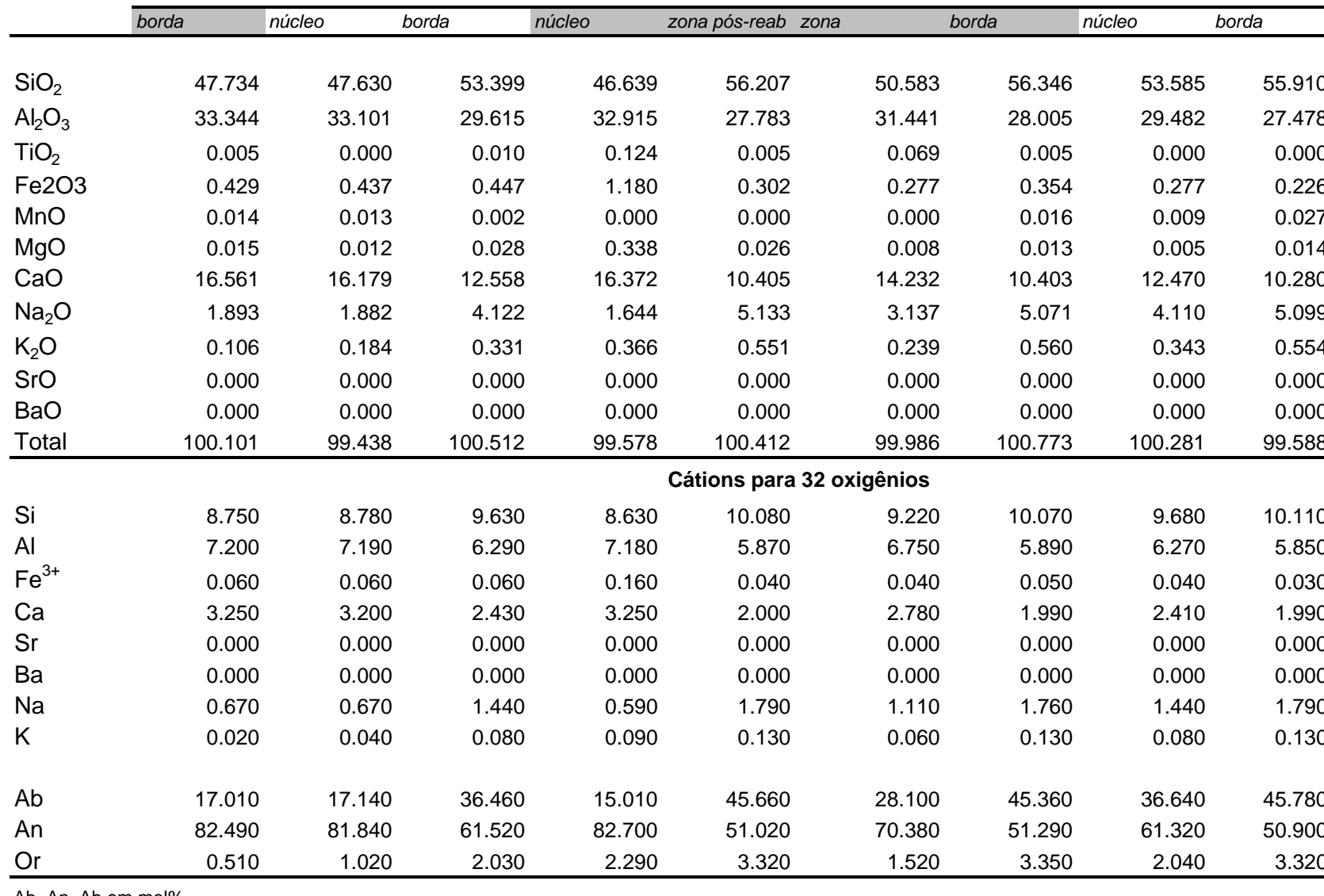

amostra: PUL-44D \begin{tabular}{ll}
\hline 1.1 & 19.1 \\
$\begin{array}{l}\text { plag zonado c/ text peneira nas } \\
\text { bordas }\end{array}$ & $\begin{array}{l}\text { gde feno idio } \\
\text { limpo } \mathrm{d} / \text { fina }\end{array}$ \\
bod post
\end{tabular}

\begin{tabular}{rrr}
\hline \multicolumn{1}{c}{ núcleo } & \multicolumn{2}{c}{ núcleo } \\
\hline 54.151 & 55.902 & 54.664 \\
28.628 & 27.735 & 28.677 \\
0.020 & 0.025 & 0.000 \\
0.360 & 0.189 & 0.222 \\
0.000 & 0.000 & 0.001 \\
0.013 & 0.005 & 0.015 \\
11.051 & 10.351 & 11.152 \\
4.765 & 5.506 & 4.618 \\
0.496 & 0.542 & 0.484 \\
0.000 & 0.000 & 0.000 \\
0.000 & 0.000 & 0.000 \\
99.484 & 100.255 & 99.833 \\
\hline & & \\
9.840 & 10.060 & 9.880 \\
6.120 & 5.880 & 6.100 \\
0.050 & 0.030 & 0.030 \\
2.150 & 2.000 & 2.160 \\
0.000 & 0.000 & 0.000 \\
0.000 & 0.000 & 0.000 \\
1.680 & 1.920 & 1.620 \\
0.110 & 0.120 & 0.110 \\
& & \\
42.640 & 47.520 & 41.650 \\
54.570 & 49.500 & 55.530 \\
2.790 & 2.970 & 2.830 \\
\hline & &
\end{tabular}


ANEXO V - Tabelas 1.

Análise química dos plagioclásios

UFRS

Amostra: PUL-44D

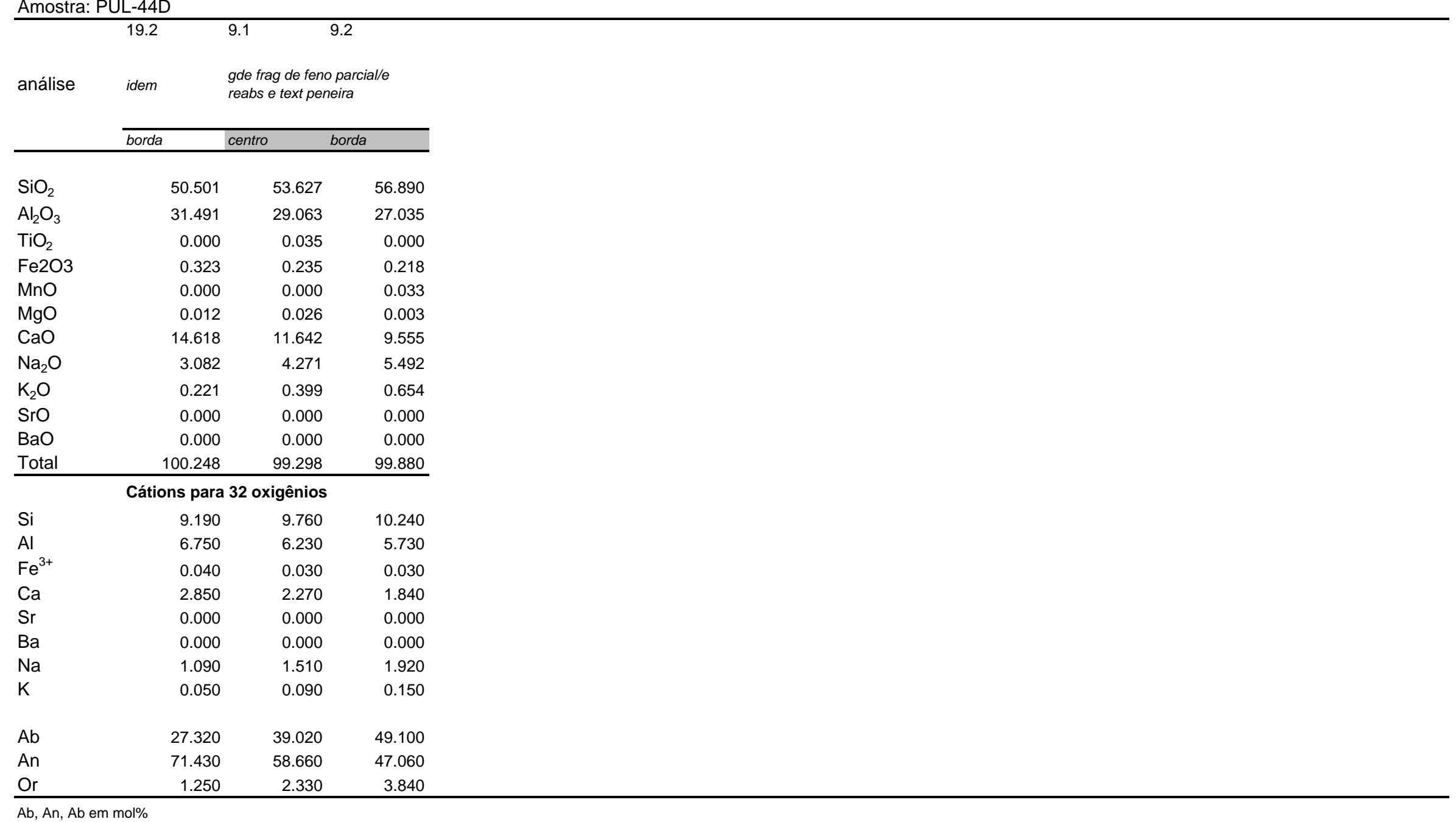

$\mathrm{Ab}, \mathrm{An}, \mathrm{Ab}$ em mol\%

mfeno: microfenocristais; feno: fenocristais; plag: plagioclásio; idio: idiomórfico; zonea: zoneamento; text; textura; reab: reabsorção; mmaf: minerais máficos; ox: óxidos; qtz: quartzo; poiqui: poiquilítico; gde: grande; irreg: irregular 
ANEXO V - Tabelas 2.

Análise química das biotitas

UFC

Amostra: PUL-20A

\begin{tabular}{|c|c|c|c|c|}
\hline & 14VM & $13 \mathrm{VM}$ & $\mathrm{BIO} \cdot 2.13 \mathrm{VM}$ & BIO.7.VD \\
\hline análise & $\begin{array}{l}\text { intercresc c/ } \\
\text { plag }\end{array}$ & bast oxid & & $\begin{array}{l}\text { inclusa em } \\
\text { opx }\end{array}$ \\
\hline
\end{tabular}

\begin{tabular}{lrrrr}
\hline $\mathrm{SiO}_{2}$ & 35.598 & 37.590 & 35.303 & 35.927 \\
$\mathrm{TiO}_{2}$ & 5.044 & 6.613 & 5.757 & 5.181 \\
$\mathrm{Al}_{2} \mathrm{O}_{3}$ & 15.046 & 14.975 & 13.873 & 13.524 \\
$\mathrm{Cr}_{2} \mathrm{O}_{3}$ & 0.000 & 0.000 & 0.000 & 0.000 \\
$\mathrm{FeO}$ & 19.560 & 11.969 & 16.765 & 18.896 \\
$\mathrm{Fe}_{2} \mathrm{O}_{3}$ & 0.000 & 0.000 & 0.000 & 0.000 \\
$\mathrm{MnO}$ & 0.000 & 0.031 & 0.024 & 0.054 \\
$\mathrm{MgO}$ & 10.290 & 13.933 & 11.667 & 11.811 \\
$\mathrm{BaO}$ & 0.264 & 0.492 & 0.710 & 0.524 \\
$\mathrm{CaO}$ & 0.036 & 0.000 & 0.046 & 0.004 \\
$\mathrm{Na}{ }_{2} \mathrm{O}$ & 0.273 & 0.259 & 0.347 & 0.177 \\
$\mathrm{~K} 2 \mathrm{O}$ & 8.806 & 9.535 & 8.519 & 9.078 \\
$\mathrm{~F}$ & 2.271 & 2.449 & 1.983 & 1.005 \\
$\mathrm{Cl}$ & 0.219 & 0.233 & 0.206 & 0.244 \\
$\mathrm{H}{ }_{2} \mathrm{O}$ & 0.730 & 0.720 & 0.850 & 1.330 \\
Total & 98.140 & 98.800 & 96.050 & 97.760 \\
\hline & & & & \\
O_F_CL & 1.010 & 1.080 & 0.880 & 0.480 \\
CTOTAL & 97.130 & 97.720 & 95.170 & 97.280 \\
\hline
\end{tabular}

UFRI

\begin{tabular}{llll} 
Amostra: PUL-38A & & \\
\hline 5VM & BIO.8.VM & BIO.10VD & BIO.17VD
\end{tabular}

bast oxid $\quad \mathrm{c} /$ incl $\quad \mathrm{c} / \mathrm{incl} \quad \mathrm{c} / \mathrm{incl} d \mathrm{de}$

\begin{tabular}{rrrr}
\hline 35.560 & 35.940 & 36.036 & 36.536 \\
5.484 & 5.397 & 5.626 & 5.441 \\
13.418 & 13.849 & 13.557 & 13.510 \\
0.000 & 0.000 & 0.000 & 0.000 \\
21.491 & 19.320 & 18.974 & 18.750 \\
0.000 & 0.000 & 0.000 & 0.000 \\
0.122 & 0.041 & 0.059 & 0.089 \\
9.855 & 11.445 & 11.808 & 11.682 \\
0.590 & 0.461 & 0.575 & 0.839 \\
0.000 & 0.044 & 0.010 & 0.000 \\
0.404 & 0.527 & 0.467 & 0.548 \\
8.860 & 8.784 & 8.787 & 8.921 \\
0.354 & 0.612 & 0.612 & 0.286 \\
0.279 & 0.280 & 0.173 & 0.211 \\
1.610 & 1.520 & 1.550 & 1.700 \\
98.030 & 98.220 & 98.230 & 98.510 \\
\hline & & & \\
0.210 & 0.320 & 0.300 & 0.170 \\
97.820 & 97.900 & 97.930 & 98.340 \\
\hline
\end{tabular}

Cátions recalculados para $220+20 H$

\begin{tabular}{lllll}
$\mathrm{Si}$ & 5.136 & 5.216 & 5.142 & 5.111 \\
$\mathrm{Al}^{\mathrm{IV}}$ & 2.557 & 2.447 & 2.380 & 2.266 \\
$\mathrm{Al}^{\mathrm{VI}}$ & 0.000 & 0.000 & 0.000 & 0.000 \\
$\mathrm{Ti}$ & 0.547 & 0.690 & 0.631 & 0.554 \\
$\mathrm{Fe}^{3+}$ & 0.000 & 0.000 & 0.000 & 0.000 \\
$\mathrm{Fe}^{2+}$ & 2.360 & 1.389 & 2.042 & 2.248 \\
$\mathrm{Cr}$ & 0.000 & 0.000 & 0.000 & 0.000 \\
$\mathrm{Mn}$ & 0.000 & 0.004 & 0.003 & 0.007 \\
$\mathrm{Mg}$ & 2.213 & 2.882 & 2.534 & 2.505 \\
$\mathrm{Ba}$ & 0.015 & 0.027 & 0.041 & 0.029 \\
$\mathrm{Ca}$ & 0.006 & 0.000 & 0.007 & 0.001 \\
$\mathrm{Na}$ & 0.076 & 0.070 & 0.098 & 0.049 \\
$\mathrm{~K}$ & 1.621 & 1.688 & 1.583 & 1.647 \\
$\mathrm{mg \#}$ & & & & \\
\hline & 0.484 & 0.675 & 0.554 & 0.527 \\
\hline
\end{tabular}

\begin{tabular}{llll}
5.062 & 5.060 & 5.062 & 5.097 \\
2.250 & 2.296 & 2.243 & 2.219 \\
0.000 & 0.000 & 0.000 & 0.000 \\
0.587 & 0.572 & 0.594 & 0.571 \\
0.000 & 0.000 & 0.000 & 0.000 \\
2.559 & 2.275 & 2.229 & 2.187 \\
0.000 & 0.000 & 0.000 & 0.000 \\
0.015 & 0.005 & 0.007 & 0.011 \\
2.091 & 2.402 & 2.473 & 2.429 \\
0.033 & 0.025 & 0.032 & 0.046 \\
0.000 & 0.007 & 0.002 & 0.000 \\
0.112 & 0.144 & 0.127 & 0.148 \\
1.609 & 1.578 & 1.575 & 1.588 \\
0.450 & 0.514 & 0.526 & 0.526 \\
\hline
\end{tabular}

$\mathrm{mg} \#=100 *\left[\mathrm{Mg} /\left(\mathrm{Mg}+\mathrm{Fe}^{2+}+\mathrm{Fe}^{3+}\right)\right]$

plag: plagioclásio; bast oxid: bastante oxidado; incl: inclusão; opx: ortopiroxênio frag: fragmento; idio: idiomórfico; xeno: xenomórfico; engl: englobado feno: fenocristal 
ANEXO V - Tabelas 2.

Análise química das biotitas

UFRI

Amostra: PUL-38A

\begin{tabular}{lrr} 
& \multicolumn{2}{l}{ 6VD } \\
análise & $\begin{array}{l}\text { intercresc } \\
\text { c/plag }\end{array}$ & \multicolumn{2}{l}{ bast oxid } \\
& 36.798 & 36.428 \\
$\mathrm{SiO}_{2}$ & 5.250 & 5.647 \\
$\mathrm{TiO}_{2}$ & 13.805 & 13.860 \\
$\mathrm{Al}_{2} \mathrm{O}_{3}$ & 0.000 & 0.000 \\
$\mathrm{Cr}_{2} \mathrm{O}_{3}$ & 19.171 & 19.226 \\
$\mathrm{FeO}$ & 0.000 & 0.000 \\
$\mathrm{Fe}_{2} \mathrm{O}_{3}$ & 0.028 & 0.076 \\
$\mathrm{MnO}$ & 11.828 & 11.519 \\
$\mathrm{MgO}$ & 0.342 & 0.260 \\
$\mathrm{BaO}$ & 0.000 & 0.000 \\
$\mathrm{CaO}$ & 0.501 & 0.500 \\
$\mathrm{Na}{ }_{2} \mathrm{O}$ & 9.147 & 9.039 \\
$\mathrm{~K}_{2} \mathrm{O}$ & 0.810 & 0.768 \\
$\mathrm{~F}$ & 0.210 & 0.223 \\
$\mathrm{Cl}$ & 1.470 & 1.480 \\
$\mathrm{H}_{2} \mathrm{O}$ & 99.360 & 99.030 \\
$\mathrm{Total}$ & & \\
\hline & 0.390 & 0.370 \\
$\mathrm{O} \_\mathrm{F} \_\mathrm{CL}$ & 98.970 & 98.660 \\
$\mathrm{CTOTAL}$ & &
\end{tabular}

\begin{tabular}{lll}
$\mathrm{Si}$ & 5.119 & 5.084 \\
$\mathrm{Al}^{\mathrm{lv}}$ & 2.262 & 2.278 \\
$\mathrm{Al}^{\mathrm{v}}$ & 0.000 & 0.000 \\
$\mathrm{Ti}^{\mathrm{N}}$ & 0.549 & 0.593 \\
$\mathrm{Fe}^{3+}$ & 0.000 & 0.000 \\
$\mathrm{Fe}^{2+}$ & 2.230 & 2.244 \\
$\mathrm{Cr}$ & 0.000 & 0.000 \\
$\mathrm{Mn}$ & 0.003 & 0.009 \\
$\mathrm{Mg}$ & 2.453 & 2.397 \\
$\mathrm{Ba}$ & 0.019 & 0.014 \\
$\mathrm{Ca}$ & 0.000 & 0.000 \\
$\mathrm{Na}$ & 0.135 & 0.135 \\
$\mathrm{~K}$ & 1.623 & 1.609 \\
& & \\
$\mathrm{mg} \#$ & 0.524 & 0.516 \\
\hline
\end{tabular}

UFRS

Amostra: PUL-44A

\begin{tabular}{|c|c|c|c|c|c|}
\hline $\begin{array}{l}\text { 5VD } \\
\text { idio com } \\
\text { borda plag }\end{array}$ & $\begin{array}{l}\text { 4VM } \\
\text { feno idio } \\
\text { hexag }\end{array}$ & $\begin{array}{l}\text { 10VM } \\
\text { sub-idio }\end{array}$ & $\begin{array}{l}14 \mathrm{VD} \\
\text { placa fina }\end{array}$ & $\begin{array}{l}21 \mathrm{VM} \\
\text { frag feno }\end{array}$ & $\begin{array}{l}\text { 2VMLIT } \\
\text { em frag } \\
\text { litico }\end{array}$ \\
\hline 35.879 & 36.067 & 36.217 & 36.560 & 36.671 & 35.503 \\
\hline 5.434 & 5.427 & 5.353 & 5.084 & 5.200 & 5.237 \\
\hline 13.771 & 13.653 & 13.486 & 14.214 & 13.335 & 14.720 \\
\hline 0.000 & 0.000 & 0.000 & 0.000 & 0.000 & 0.000 \\
\hline 21.412 & 20.763 & 20.885 & 19.894 & 20.409 & 21.308 \\
\hline 0.000 & 0.000 & 0.000 & 0.000 & 0.000 & 0.000 \\
\hline 0.091 & 0.079 & 0.153 & 0.178 & 0.130 & 0.107 \\
\hline 10.215 & 10.303 & 10.062 & 9.573 & 10.428 & 9.843 \\
\hline 0.098 & 0.501 & 0.432 & 0.663 & 0.860 & 0.227 \\
\hline 0.000 & 0.000 & 0.014 & 0.000 & 0.000 & 0.006 \\
\hline 0.367 & 0.438 & 0.417 & 0.344 & 0.439 & 0.337 \\
\hline 9.221 & 9.179 & 8.809 & 8.544 & 8.642 & 9.140 \\
\hline 0.334 & 0.433 & 0.462 & 0.413 & 0.478 & 0.484 \\
\hline 0.250 & 0.269 & 0.238 & 0.240 & 0.224 & 0.196 \\
\hline 1.650 & 1.600 & 1.590 & 1.610 & 1.590 & 1.590 \\
\hline 98.720 & 98.710 & 98.120 & 97.320 & 98.410 & 98.700 \\
\hline 0.200 & 0.240 & 0.250 & 0.230 & 0.250 & 0.250 \\
\hline 98.520 & 98.470 & 97.870 & 97.090 & 98.160 & 98.450 \\
\hline
\end{tabular}

Cátions recalculados para $220+20 H$

\begin{tabular}{llllll}
5.047 & 5.082 & 5.124 & 5.174 & 5.167 & 5.002 \\
2.281 & 2.265 & 2.247 & 2.369 & 2.213 & 2.442 \\
0.000 & 0.000 & 0.000 & 0.000 & 0.000 & 0.000 \\
0.575 & 0.575 & 0.570 & 0.541 & 0.551 & 0.555 \\
0.000 & 0.000 & 0.000 & 0.000 & 0.000 & 0.000 \\
2.519 & 2.446 & 2.471 & 2.355 & 2.405 & 2.511 \\
0.000 & 0.000 & 0.000 & 0.000 & 0.000 & 0.000 \\
0.011 & 0.009 & 0.018 & 0.021 & 0.016 & 0.013 \\
2.142 & 2.164 & 2.122 & 2.020 & 2.190 & 2.067 \\
0.005 & 0.028 & 0.024 & 0.037 & 0.047 & 0.013 \\
0.000 & 0.000 & 0.002 & 0.000 & 0.000 & 0.001 \\
0.100 & 0.120 & 0.114 & 0.094 & 0.120 & 0.092 \\
1.655 & 1.650 & 1.590 & 1.543 & 1.553 & 1.643 \\
& & & & & \\
0.460 & 0.469 & 0.462 & 0.462 & 0.477 & 0.452 \\
\hline
\end{tabular}


ANEXO V - Tabelas 2.

Análise química das biotitas

UFRS

Amostra: PUL-44A

\begin{tabular}{lr} 
análise & \multicolumn{1}{c}{$\begin{array}{l}\text { 18VD } \\
\text { com borda } \\
\end{array}$} \\
\hline $\mathrm{SiO}_{2}$ & 36.481 \\
$\mathrm{TiO}_{2}$ & 5.098 \\
$\mathrm{Al}_{2} \mathrm{O}_{3}$ & 14.208 \\
$\mathrm{Cr}_{2} \mathrm{O}_{3}$ & 0.000 \\
$\mathrm{FeO}^{2}$ & 21.021 \\
$\mathrm{Fe}_{2} \mathrm{O}_{3}$ & 0.000 \\
$\mathrm{MnO}$ & 0.090 \\
$\mathrm{MgO}$ & 10.667 \\
$\mathrm{BaO}$ & 0.104 \\
$\mathrm{CaO}$ & 0.000 \\
$\mathrm{Na}{ }_{2} \mathrm{O}$ & 0.488 \\
$\mathrm{~K}_{2} \mathrm{O}$ & 9.299 \\
$\mathrm{~F}$ & 0.593 \\
$\mathrm{Cl}$ & 0.230 \\
$\mathrm{H}_{2} \mathrm{O}$ & 1.560 \\
Total & 99.840 \\
\hline & \\
$\mathrm{O} \_\mathrm{F} \_\mathrm{CL}$ & 0.300 \\
$\mathrm{CTOTAL}$ & 99.540 \\
\hline
\end{tabular}

\begin{tabular}{ll}
$\mathrm{Si}$ & 5.075 \\
$\mathrm{Al}^{\mathrm{lv}}$ & 2.328 \\
$\mathrm{Al}^{\mathrm{vI}}$ & 0.000 \\
$\mathrm{Ti}$ & 0.533 \\
$\mathrm{Fe}^{3+}$ & 0.000 \\
$\mathrm{Fe}^{{ }^{++}}$ & 2.445 \\
$\mathrm{Cr}$ & 0.000 \\
$\mathrm{Mn}$ & 0.011 \\
$\mathrm{Mg}$ & 2.212 \\
$\mathrm{Ba}$ & 0.006 \\
$\mathrm{Ca}$ & 0.000 \\
$\mathrm{Na}$ & 0.132 \\
$\mathrm{~K}$ & 1.650 \\
$\mathrm{mg}$ & \\
$\mathrm{mg}$ & 0.475 \\
\hline
\end{tabular}

UFRS

\begin{tabular}{|c|c|c|c|c|c|c|}
\hline \multicolumn{7}{|l|}{ 14VM } \\
\hline engl plag & feno & & incl de plag & $\begin{array}{l}\text { intercresc c/ } \\
\text { plag }\end{array}$ & $\begin{array}{l}\text { placa fina e } \\
\text { longa }\end{array}$ & $\begin{array}{l}\text { pertence a } \\
\text { matriz }\end{array}$ \\
\hline 35.672 & 35.861 & 35.742 & 35.617 & 36.133 & 35.490 & 35.465 \\
\hline 5.360 & 5.304 & 5.145 & 5.230 & 5.803 & 5.283 & 5.445 \\
\hline 13.730 & 13.416 & 13.563 & 13.715 & 13.665 & 13.883 & 13.688 \\
\hline 0.000 & 0.000 & 0.000 & 0.000 & 0.000 & 0.000 & 0.000 \\
\hline 20.371 & 20.638 & 20.906 & 20.629 & 20.383 & 21.577 & 20.927 \\
\hline 0.000 & 0.000 & 0.000 & 0.000 & 0.000 & 0.000 & 0.000 \\
\hline 0.071 & 0.072 & 0.048 & 0.087 & 0.059 & 0.118 & 0.115 \\
\hline 10.424 & 10.450 & 10.437 & 10.995 & 10.201 & 10.302 & 10.259 \\
\hline 0.535 & 0.192 & 0.693 & 0.216 & 0.715 & 0.312 & 0.603 \\
\hline 0.005 & 0.015 & 0.000 & 0.008 & 0.000 & 0.015 & 0.011 \\
\hline 0.398 & 0.472 & 0.449 & 0.430 & 0.423 & 0.431 & 0.430 \\
\hline 8.726 & 9.382 & 9.038 & 9.344 & 8.857 & 9.371 & 9.041 \\
\hline 0.529 & 0.359 & 0.603 & 0.607 & 0.501 & 0.606 & 0.213 \\
\hline 0.248 & 0.288 & 0.301 & 0.281 & 0.265 & 0.207 & 0.268 \\
\hline 1.540 & 1.620 & 1.500 & 1.510 & 1.570 & 1.530 & 1.690 \\
\hline 97.610 & 98.070 & 98.420 & 98.670 & 98.580 & 99.120 & 98.150 \\
\hline 0.280 & 0.220 & 0.320 & 0.320 & 0.270 & 0.300 & 0.150 \\
\hline 97.330 & 97.850 & 98.100 & 98.350 & 98.310 & 98.820 & 98.000 \\
\hline
\end{tabular}

Cátions recalculados para $220+2 \mathrm{OH}$

\begin{tabular}{lllllll}
5.074 & 5.079 & 5.079 & 5.034 & 5.091 & 5.015 & 5.022 \\
2.300 & 2.238 & 2.270 & 2.283 & 2.267 & 2.310 & 2.283 \\
0.000 & 0.000 & 0.000 & 0.000 & 0.000 & 0.000 & 0.000 \\
0.574 & 0.565 & 0.550 & 0.556 & 0.615 & 0.562 & 0.580 \\
0.000 & 0.000 & 0.000 & 0.000 & 0.000 & 0.000 & 0.000 \\
2.423 & 2.445 & 2.485 & 2.438 & 2.402 & 2.550 & 2.478 \\
0.000 & 0.000 & 0.000 & 0.000 & 0.000 & 0.000 & 0.000 \\
0.009 & 0.009 & 0.006 & 0.010 & 0.007 & 0.014 & 0.014 \\
2.211 & 2.207 & 2.211 & 2.317 & 2.143 & 2.170 & 2.166 \\
0.030 & 0.011 & 0.039 & 0.012 & 0.039 & 0.017 & 0.033 \\
0.001 & 0.002 & 0.000 & 0.001 & 0.000 & 0.002 & 0.002 \\
0.110 & 0.130 & 0.124 & 0.118 & 0.116 & 0.118 & 0.118 \\
1.584 & 1.695 & 1.639 & 1.685 & 1.592 & 1.689 & 1.633 \\
& & & & & & \\
0.477 & 0.474 & 0.471 & 0.487 & 0.472 & 0.460 & 0.466 \\
\hline
\end{tabular}


ANEXO V - Tabelas 2.

Análise química das biotitas

UFRS

Amostra: PUL-44C

\begin{tabular}{|c|c|c|c|c|c|}
\hline análise & $\begin{array}{l}\text { 35VM } \\
\text { cristal xeno }\end{array}$ & $\begin{array}{l}\text { BIO3VD } \\
\text { incl de } p x / \\
\text { dobrada }\end{array}$ & $\begin{array}{l}\mathrm{BIO} 2 \mathrm{VM} \\
\text { feno } \\
\text { dobrado } \mathrm{cl} \\
\text { incl }\end{array}$ & $\begin{array}{l}\text { BIO40VM } \\
\text { margem corr } \\
\text { / incl de } \\
\text { opacos }\end{array}$ & $\begin{array}{l}5 \mathrm{VM} \\
\text { feno }\end{array}$ \\
\hline $\mathrm{SiO}_{2}$ & 35.398 & 36.133 & 35.513 & 35.203 & 35.478 \\
\hline $\mathrm{TiO}_{2}$ & 5.399 & 5.797 & 5.524 & 5.412 & 5.334 \\
\hline $\mathrm{Al}_{2} \mathrm{O}_{3}$ & 13.751 & 13.400 & 13.584 & 13.277 & 13.680 \\
\hline $\mathrm{Cr}_{2} \mathrm{O}_{3}$ & 0.000 & 0.000 & 0.000 & 0.000 & 0.000 \\
\hline $\mathrm{FeO}$ & 21.788 & 21.493 & 21.265 & 20.701 & 20.437 \\
\hline $\mathrm{Fe}_{2} \mathrm{O}_{3}$ & 0.000 & 0.000 & 0.000 & 0.000 & 0.000 \\
\hline $\mathrm{MnO}$ & 0.143 & 0.127 & 0.123 & 0.155 & 0.093 \\
\hline $\mathrm{MgO}$ & 9.997 & 10.138 & 10.010 & 10.267 & 10.217 \\
\hline $\mathrm{BaO}$ & 0.784 & 0.661 & 0.315 & 0.604 & 0.456 \\
\hline $\mathrm{CaO}$ & 0.000 & 0.009 & 0.000 & 0.000 & 0.020 \\
\hline $\mathrm{Na}_{2} \mathrm{O}$ & 0.437 & 0.362 & 0.324 & 0.454 & 0.516 \\
\hline $\mathrm{K}_{2} \mathrm{O}$ & 9.125 & 9.232 & 9.224 & 10.300 & 9.636 \\
\hline $\mathrm{F}$ & 0.638 & 0.324 & 0.635 & 0.294 & 0.139 \\
\hline $\mathrm{Cl}$ & 0.292 & 0.270 & 0.310 & 0.269 & 0.245 \\
\hline $\mathrm{H}_{2} \mathrm{O}$ & 1.490 & 1.660 & 1.480 & 1.640 & 1.730 \\
\hline Total & 99.240 & 99.610 & 98.310 & 98.580 & 97.980 \\
\hline O_F_CL & 0.330 & 0.200 & 0.340 & 0.180 & 0.110 \\
\hline CTOTAL & 98.910 & 99.410 & 97.970 & 98.400 & 97.870 \\
\hline
\end{tabular}

Cátions recalculados para $220+2 \mathrm{OH}$

\begin{tabular}{llllll}
$\mathrm{Si}$ & 5.023 & 5.061 & 5.059 & 5.012 & 5.027 \\
$\mathrm{Al}^{\mathrm{lv}}$ & 2.298 & 2.210 & 2.279 & 2.226 & 2.283 \\
$\mathrm{Al}^{\mathrm{vi}}$ & 0.000 & 0.000 & 0.000 & 0.000 & 0.000 \\
$\mathrm{Ti}$ & 0.576 & 0.611 & 0.592 & 0.580 & 0.569 \\
$\mathrm{Fe}^{3+}$ & 0.000 & 0.000 & 0.000 & 0.000 & 0.000 \\
$\mathrm{Fe}^{2+}$ & 2.585 & 2.518 & 2.533 & 2.465 & 2.422 \\
$\mathrm{Cr}$ & 0.000 & 0.000 & 0.000 & 0.000 & 0.000 \\
$\mathrm{Mn}$ & 0.017 & 0.015 & 0.015 & 0.019 & 0.011 \\
$\mathrm{Mg}$ & 2.115 & 2.117 & 2.126 & 2.179 & 2.158 \\
$\mathrm{Ba}$ & 0.044 & 0.036 & 0.018 & 0.034 & 0.025 \\
$\mathrm{Ca}$ & 0.000 & 0.001 & 0.000 & 0.000 & 0.003 \\
$\mathrm{Na}$ & 0.120 & 0.098 & 0.089 & 0.125 & 0.142 \\
$\mathrm{~K}$ & 1.652 & 1.650 & 1.676 & 1.871 & 1.742 \\
& & & & & \\
$\mathrm{mg} \#$ & 0.450 & 0.457 & 0.456 & 0.469 & 0.471 \\
\hline
\end{tabular}

Amostra: PUL-44D

02. Iaranja 33amarela 34VD

incl em px limpa borda frag peq incl

\begin{tabular}{|c|c|c|}
\hline 35.858 & 35.760 & 36.039 \\
\hline 5.224 & 5.078 & 5.409 \\
\hline 13.479 & 13.884 & 13.536 \\
\hline 0.000 & 0.000 & 0.000 \\
\hline 21.373 & 21.772 & 20.714 \\
\hline 0.000 & 0.000 & 0.000 \\
\hline 0.097 & 0.104 & 0.096 \\
\hline 9.874 & 10.107 & 10.144 \\
\hline 0.182 & 0.291 & 0.477 \\
\hline 0.030 & 0.006 & 0.000 \\
\hline 0.385 & 0.454 & 0.408 \\
\hline 9.031 & 9.076 & 8.765 \\
\hline 0.603 & 0.358 & 0.180 \\
\hline 0.273 & 0.300 & 0.253 \\
\hline 1.500 & 1.620 & 1.710 \\
\hline 97.910 & 98.810 & 97.730 \\
\hline 0.320 & 0.220 & 0.130 \\
\hline 97.590 & 98.590 & 97.600 \\
\hline 5.111 & 5.046 & 5.094 \\
\hline 2.263 & 2.307 & 2.253 \\
\hline 0.000 & 0.000 & 0.000 \\
\hline 0.560 & 0.539 & 0.575 \\
\hline 0.000 & 0.000 & 0.000 \\
\hline 2.548 & 2.569 & 2.449 \\
\hline 0.000 & 0.000 & 0.000 \\
\hline 0.012 & 0.012 & 0.011 \\
\hline 2.098 & 2.126 & 2.138 \\
\hline 0.010 & 0.016 & 0.026 \\
\hline 0.005 & 0.001 & 0.000 \\
\hline 0.106 & 0.124 & 0.112 \\
\hline 1.642 & 1.634 & 1.581 \\
\hline 0.452 & 0.453 & 0.466 \\
\hline
\end{tabular}


ANEXO V - Tabelas 2.

Análise química das biotitas

UFRS

Amostra: PUL-44D

\begin{tabular}{|c|c|c|c|c|c|}
\hline análise & $\begin{array}{l}\text { 30VM } \\
\text { corte } \\
\text { basal/ sub- } \\
\text { idio }\end{array}$ & $\begin{array}{l}\text { 14VD } \\
\text { com } \\
\text { microincl } \\
\text { plag }\end{array}$ & $\begin{array}{l}\text { 13VD } \\
\text { limpo }\end{array}$ & $\begin{array}{l}\text { 07VD } \\
\text { peq incl de } \\
\text { plag }\end{array}$ & $\begin{array}{l}\text { 06VM } \\
\text { intercersc } \\
\text { plag }\end{array}$ \\
\hline $\mathrm{SiO}_{2}$ & 35.617 & 36.388 & 36.390 & 36.633 & 36.333 \\
\hline $\mathrm{TiO}_{2}$ & 5.366 & 5.176 & 5.091 & 5.529 & 5.605 \\
\hline $\mathrm{Al}_{2} \mathrm{O}_{3}$ & 13.283 & 13.934 & 13.659 & 13.273 & 13.976 \\
\hline $\mathrm{Cr}_{2} \mathrm{O}_{3}$ & 0.000 & 0.000 & 0.000 & 0.000 & 0.000 \\
\hline $\mathrm{FeO}$ & 20.827 & 20.965 & 21.072 & 20.319 & 20.705 \\
\hline $\mathrm{Fe}_{2} \mathrm{O}_{3}$ & 0.000 & 0.000 & 0.000 & 0.000 & 0.000 \\
\hline $\mathrm{MnO}$ & 0.141 & 0.113 & 0.101 & 0.109 & 0.098 \\
\hline $\mathrm{MgO}$ & 10.099 & 10.227 & 10.407 & 10.555 & 10.088 \\
\hline $\mathrm{BaO}$ & 0.650 & 0.195 & 0.336 & 0.586 & 0.281 \\
\hline $\mathrm{CaO}$ & 0.013 & 0.018 & 0.000 & 0.000 & 0.014 \\
\hline $\mathrm{Na}_{2} \mathrm{O}$ & 0.490 & 0.409 & 0.417 & 0.430 & 0.357 \\
\hline $\mathrm{K}_{2} \mathrm{O}$ & 8.944 & 9.097 & 9.039 & 8.760 & 9.053 \\
\hline $\mathrm{F}$ & 0.278 & 0.307 & 0.340 & 0.670 & 0.568 \\
\hline $\mathrm{Cl}$ & 0.268 & 0.231 & 0.253 & 0.266 & 0.196 \\
\hline $\mathrm{H}_{2} \mathrm{O}$ & 1.650 & 1.680 & 1.650 & 1.490 & 1.560 \\
\hline Total & 97.630 & 98.740 & 98.760 & 98.620 & 98.830 \\
\hline O_F_CL & 0.180 & 0.180 & 0.200 & 0.340 & 0.280 \\
\hline СТ̄OTAL & 97.450 & 98.560 & 98.560 & 98.280 & 98.550 \\
\hline
\end{tabular}

Cátions recalculados para $22 \mathrm{O}+\mathbf{2 O H}$

\begin{tabular}{llllll}
$\mathrm{Si}$ & 5.076 & 5.095 & 5.107 & 5.160 & 5.097 \\
$\mathrm{Al}^{\mathrm{Vv}}$ & 2.229 & 2.298 & 2.258 & 2.202 & 2.309 \\
$\mathrm{Al}^{\mathrm{VI}}$ & 0.000 & 0.000 & 0.000 & 0.000 & 0.000 \\
$\mathrm{Ti}$ & 0.575 & 0.545 & 0.537 & 0.586 & 0.591 \\
$\mathrm{Fe}^{3+}$ & 0.000 & 0.000 & 0.000 & 0.000 & 0.000 \\
$\mathrm{Fe}^{2+}$ & 2.482 & 2.455 & 2.473 & 2.394 & 2.429 \\
$\mathrm{Cr}$ & 0.000 & 0.000 & 0.000 & 0.000 & 0.000 \\
$\mathrm{Mn}$ & 0.017 & 0.013 & 0.012 & 0.013 & 0.012 \\
$\mathrm{Mg}$ & 2.146 & 2.135 & 2.177 & 2.216 & 2.110 \\
$\mathrm{Ba}$ & 0.036 & 0.011 & 0.018 & 0.032 & 0.015 \\
$\mathrm{Ca}$ & 0.002 & 0.003 & 0.000 & 0.000 & 0.002 \\
$\mathrm{Na}$ & 0.135 & 0.111 & 0.113 & 0.117 & 0.097 \\
$\mathrm{~K}$ & 1.626 & 1.625 & 1.618 & 1.574 & 1.620 \\
$\mathrm{mg}$ & & & & & \\
$\mathrm{mg}$ & 0.464 & 0.465 & 0.468 & 0.481 & 0.465 \\
\hline
\end{tabular}

FLP

Amostra: PUL-38E

\begin{tabular}{|c|c|c|}
\hline \multirow{2}{*}{$\begin{array}{l}\text { 11VM } \\
\text { intercresc } \\
\text { c/ plag }\end{array}$} & \multirow{2}{*}{$\begin{array}{l}\text { 19VM } \\
\text { feno }\end{array}$} & \multirow[t]{2}{*}{$20 \mathrm{VM}$} \\
\hline & & \\
\hline 35.792 & 35.387 & 36.191 \\
\hline 4.850 & 4.889 & 4.190 \\
\hline 13.671 & 13.351 & 13.304 \\
\hline 0.000 & 0.000 & 0.000 \\
\hline 22.051 & 22.813 & 22.355 \\
\hline 0.000 & 0.000 & 0.000 \\
\hline 0.241 & 0.269 & 0.277 \\
\hline 9.529 & 10.149 & 10.671 \\
\hline 0.248 & 0.258 & 0.064 \\
\hline 0.013 & 0.000 & 0.000 \\
\hline 0.308 & 0.385 & 0.365 \\
\hline 9.130 & 8.948 & 9.087 \\
\hline 0.495 & 1.159 & 0.642 \\
\hline 0.287 & 0.241 & 0.315 \\
\hline 1.550 & 1.250 & 1.480 \\
\hline 98.170 & 99.100 & 98.940 \\
\hline 0.270 & 0.540 & 0.340 \\
\hline 97.900 & 98.560 & 98.600 \\
\hline 5.102 & 5.072 & 5.130 \\
\hline 2.295 & 2.253 & 2.221 \\
\hline 0.000 & 0.000 & 0.000 \\
\hline 0.520 & 0.527 & 0.447 \\
\hline 0.000 & 0.000 & 0.000 \\
\hline 2.629 & 2.734 & 2.650 \\
\hline 0.000 & 0.000 & 0.000 \\
\hline 0.029 & 0.033 & 0.033 \\
\hline 2.025 & 2.168 & 2.255 \\
\hline 0.014 & 0.014 & 0.004 \\
\hline 0.002 & 0.000 & 0.000 \\
\hline 0.085 & 0.107 & 0.100 \\
\hline 1.660 & 1.636 & 1.643 \\
\hline 0.435 & 0.442 & 0.460 \\
\hline
\end{tabular}


ANEXO V - Tabelas 2.

Análise química das biotitas

CIP

Amostra: $\mathrm{H}-03$

\begin{tabular}{|c|c|c|c|c|c|c|}
\hline análise & $\begin{array}{l}\text { 5VM } \\
\text { incl plag }\end{array}$ & $\begin{array}{l}\text { 14.amarela } \\
\text { incl de ox e } \\
\text { plag }\end{array}$ & $\begin{array}{l}\text { 33VM } \\
\text { escura com } \\
\text { incl de plag / } \\
\text { engolfada } \\
\end{array}$ & $\begin{array}{l}\text { 31VM } \\
\text { engolfada } \\
\text { ext e int; } \\
\text { sem incl } \\
\end{array}$ & $\begin{array}{l}\text { 15VD } \\
\text { peq incl de } \\
\text { ox }\end{array}$ & $\begin{array}{l}34 \mathrm{VD} \\
\text { intercresc } \\
\text { borda feno } \\
\text { px } \\
\end{array}$ \\
\hline $\mathrm{SiO}_{2}$ & 35.753 & 35.861 & 35.730 & 35.669 & 36.119 & 36.436 \\
\hline $\mathrm{TiO}_{2}$ & 5.070 & 5.173 & 4.994 & 5.016 & 5.299 & 5.082 \\
\hline $\mathrm{Al}_{2} \mathrm{O}_{3}$ & 13.518 & 13.766 & 13.768 & 13.446 & 13.823 & 13.785 \\
\hline $\mathrm{Cr}_{2} \mathrm{O}_{3}$ & 0.000 & 0.000 & 0.000 & 0.000 & 0.000 & 0.000 \\
\hline $\mathrm{FeO}$ & 20.492 & 21.224 & 19.704 & 20.052 & 21.146 & 20.083 \\
\hline $\mathrm{Fe}_{2} \mathrm{O}_{3}$ & 0.000 & 0.000 & 0.000 & 0.000 & 0.000 & 0.000 \\
\hline $\mathrm{MnO}$ & 0.106 & 0.119 & 0.063 & 0.112 & 0.153 & 0.056 \\
\hline $\mathrm{MgO}$ & 10.693 & 10.617 & 10.880 & 10.707 & 10.603 & 10.729 \\
\hline $\mathrm{BaO}$ & 0.702 & 0.628 & 0.259 & 0.566 & 0.271 & 0.299 \\
\hline $\mathrm{CaO}$ & 0.009 & 0.000 & 0.020 & 0.020 & 0.000 & 0.025 \\
\hline $\mathrm{Na}_{2} \mathrm{O}$ & 0.352 & 0.408 & 0.423 & 0.341 & 0.442 & 0.344 \\
\hline $\mathrm{K}_{2} \mathrm{O}$ & 8.757 & 9.097 & 9.164 & 8.828 & 8.913 & 8.796 \\
\hline $\mathrm{F}$ & 0.355 & 0.283 & 0.429 & 0.467 & 0.714 & 1.310 \\
\hline $\mathrm{Cl}$ & 0.322 & 0.253 & 0.190 & 0.286 & 0.228 & 0.236 \\
\hline $\mathrm{H}_{2} \mathrm{O}$ & 0.000 & 0.000 & 0.000 & 0.000 & 0.000 & 0.000 \\
\hline Total & 96.130 & 97.430 & 95.620 & 95.510 & 97.710 & 97.180 \\
\hline O_F_CL & 0.220 & 0.180 & 0.220 & 0.260 & 0.350 & 0.600 \\
\hline CTOTAL & 95.910 & 97.250 & 95.400 & 95.250 & 97.360 & 96.580 \\
\hline \multicolumn{7}{|c|}{ Cátions recalculados para $220+20 H$} \\
\hline $\mathrm{Si}$ & 5.272 & 5.231 & 5.267 & 5.286 & 5.249 & 5.320 \\
\hline $\mathrm{Al}^{\mathrm{IV}}$ & 2.347 & 2.365 & 2.390 & 2.347 & 2.366 & 2.370 \\
\hline $\mathrm{Al}^{\mathrm{VI}}$ & 0.000 & 0.000 & 0.000 & 0.000 & 0.000 & 0.000 \\
\hline $\mathrm{Ti}$ & 0.562 & 0.568 & 0.554 & 0.559 & 0.579 & 0.558 \\
\hline $\mathrm{Fe}^{3+}$ & 0.000 & 0.000 & 0.000 & 0.000 & 0.000 & 0.000 \\
\hline $\mathrm{Fe}^{2+}$ & 2.527 & 2.589 & 2.429 & 2.485 & 2.570 & 2.452 \\
\hline $\mathrm{Cr}$ & 0.000 & 0.000 & 0.000 & 0.000 & 0.000 & 0.000 \\
\hline Mn & 0.013 & 0.015 & 0.008 & 0.014 & 0.019 & 0.007 \\
\hline Mg & 2.351 & 2.309 & 2.391 & 2.366 & 2.297 & 2.335 \\
\hline $\mathrm{Ba}$ & 0.041 & 0.036 & 0.015 & 0.033 & 0.015 & 0.017 \\
\hline $\mathrm{Ca}$ & 0.001 & 0.000 & 0.003 & 0.003 & 0.000 & 0.004 \\
\hline $\mathrm{Na}$ & 0.101 & 0.115 & 0.121 & 0.098 & 0.125 & 0.097 \\
\hline $\mathrm{K}$ & 1.647 & 1.693 & 1.724 & 1.669 & 1.653 & 1.639 \\
\hline mg\# & 0.482 & 0.471 & 0.496 & 0.488 & 0.472 & 0.488 \\
\hline
\end{tabular}


ANEXO V - Tabelas 3.

Análise química dos piroxênios

UFC

Amostra: PUL-20A

\begin{tabular}{|c|c|c|c|c|c|c|c|c|}
\hline análise & $\begin{array}{c}\text { PXa.01 } \\
\text { feno sub-idio }\end{array}$ & $\begin{array}{l}\text { PGa.03 } \\
\text { pigeonita / } \\
\text { mfeno idio }\end{array}$ & $\begin{array}{l}\quad \text { PXa.05 } \\
\text { sub-idio, c/ } \\
\text { bordas } \\
\text { arredond e } \\
\text { incl }\end{array}$ & $\begin{array}{l}\quad \text { PXa.6C } \\
\text { gde feno, sub- } \\
\text { idio }\end{array}$ & $\begin{array}{l}\text { PXa.6B } \\
\text { idem }\end{array}$ & $\begin{array}{l}\quad \text { PXa.09.C } \\
\text { mfeno xeno } \\
\text { intercresc na } \\
\text { borda de feno } \\
\text { 09.B }\end{array}$ & $\begin{array}{l}\text { PXa.09.B } \\
\text { fenoc sub-idio } \\
\text { c/ bordas } \\
\text { arredond }\end{array}$ & $\begin{array}{l}\quad \text { PXa.12 } \\
\text { mfeno sub- } \\
\text { idio, bordas } \\
\text { arredond }\end{array}$ \\
\hline
\end{tabular}

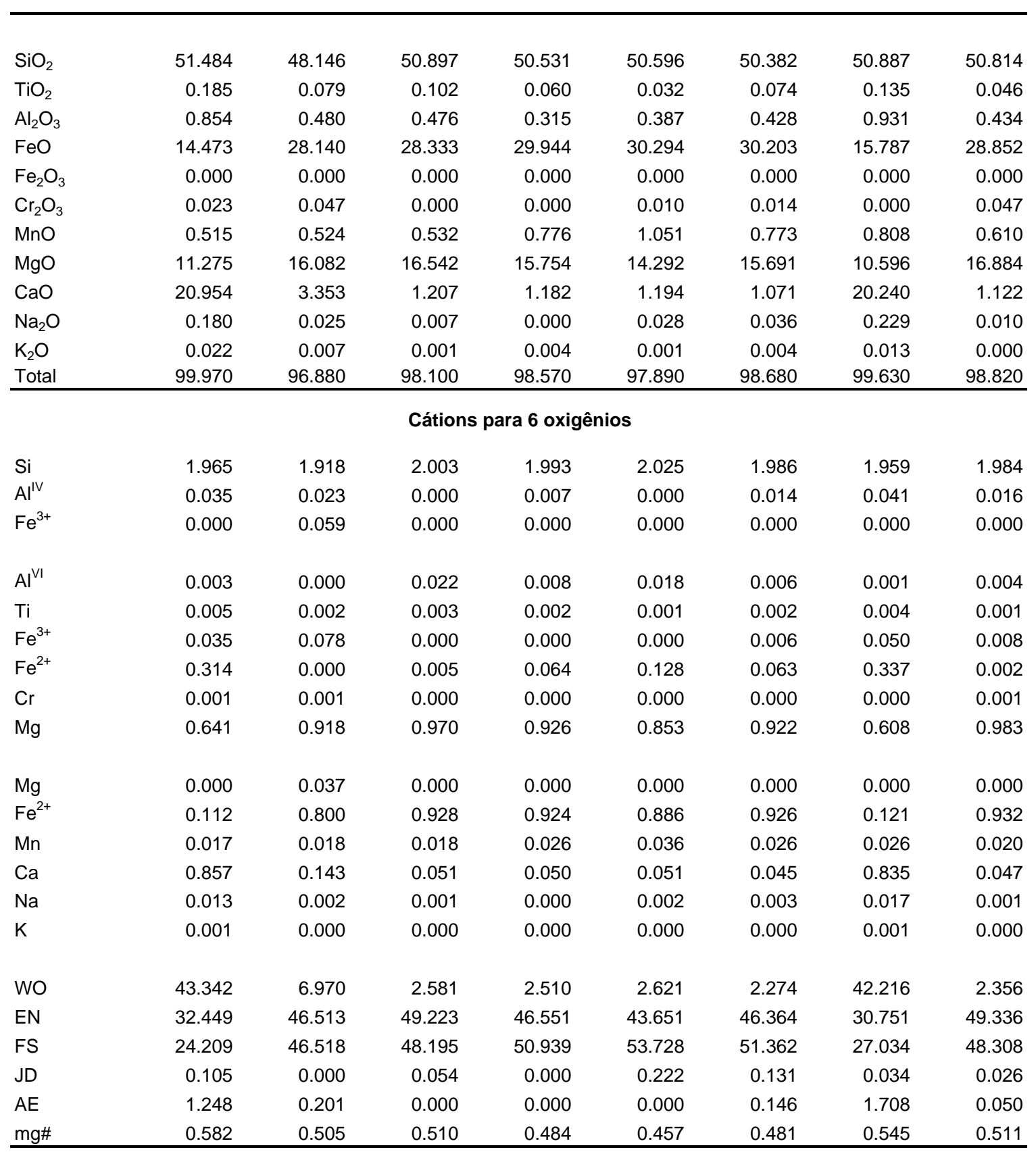

$\mathrm{Fe}^{2+}$ e $\mathrm{Fe}^{3+}$ calculados por estequeometria; $\mathrm{Wo}=\mathrm{Ca} ; \mathrm{En}=\mathrm{Mg} ; \mathrm{Fs}=\mathrm{Fe}^{2+}+\mathrm{Fe}^{3+}+\mathrm{Mn}$ $\mathrm{mg} \#=100 *\left[\mathrm{Mg} /\left(\mathrm{Mg}+\mathrm{Fe}^{2+}+\mathrm{Fe}^{3+}\right)\right]$

c: centro; i: zona intermediária; b: borda

feno: fenocristal; mfeno:microfenocristal; idio: idiomórfico; sub-idio: sub-idiomórfico; xeno: xenomórfico;

incl: inclusão; frag: fragmentado; cc: concentração; pq: pequeno; gde: grande

plag: plagioclásio; bio: biotita 
ANEXO V - Tabelas 3.

Análise química dos piroxênios

UFC

Amostra: PUL-20A

\begin{tabular}{|c|c|c|c|c|c|c|c|c|}
\hline análise & $\begin{array}{l}\text { PXa.19 } \\
\text { feno médio, } \\
\text { idio, bordas } \\
\text { arredond e } \\
\text { incl de bio }\end{array}$ & $\begin{array}{l}\quad \text { PXn.6.1C } \\
\text { mfeno sub- } \\
\text { idio } \\
\text { aparente/e } \\
\text { zonado } \\
\text { CENTRO }\end{array}$ & $\begin{array}{l}\text { PXn.6.2M } \\
\text { idem MEIO }\end{array}$ & $\begin{array}{l}\text { PXn.6.3B } \\
\text { idem BORDA } \\
\text { (cristalização } \\
\text { tardia) }\end{array}$ & $\begin{array}{l}\quad \text { PXn.3 } \\
\text { mfeno sub- } \\
\text { idio c/ fina } \\
\text { borda oxidada }\end{array}$ & $\begin{array}{l}\quad \text { PXn.1C } \\
\text { feno sub-idio } \\
\text { c/ zoneam } \\
\text { CENTRO }\end{array}$ & $\begin{array}{c}\mathrm{PXn} .1 \mathrm{~B} \\
\text { idem BORDA }\end{array}$ & $\begin{array}{r}\text { PXn.4 } \\
\text { mfeno idio }\end{array}$ \\
\hline $\mathrm{SiO}_{2}$ & 50.518 & 51.309 & 50.705 & 52.540 & 50.768 & 50.101 & 51.462 & 51.437 \\
\hline $\mathrm{TiO}_{2}$ & 0.060 & 0.080 & 0.066 & 0.141 & 0.084 & 0.112 & 0.152 & 0.187 \\
\hline $\mathrm{Al}_{2} \mathrm{O}_{3}$ & 0.421 & 0.473 & 0.443 & 0.453 & 0.701 & 0.433 & 0.772 & 0.873 \\
\hline $\mathrm{FeO}$ & 29.757 & 28.775 & 28.528 & 27.137 & 29.806 & 30.626 & 14.038 & 13.529 \\
\hline $\mathrm{Fe}_{2} \mathrm{O}_{3}$ & 0.000 & 0.000 & 0.000 & 0.000 & 0.000 & 0.000 & 0.000 & 0.000 \\
\hline $\mathrm{Cr}_{2} \mathrm{O}_{3}$ & 0.031 & 0.006 & 0.032 & 0.018 & 0.004 & 0.035 & 0.011 & 0.000 \\
\hline $\mathrm{MnO}$ & 0.687 & 0.547 & 0.544 & 0.446 & 0.729 & 0.807 & 0.327 & 0.300 \\
\hline $\mathrm{MgO}$ & 16.519 & 16.850 & 16.880 & 16.384 & 16.092 & 15.560 & 11.539 & 11.728 \\
\hline $\mathrm{CaO}$ & 1.172 & 1.050 & 1.091 & 1.041 & 1.068 & 1.035 & 20.335 & 20.560 \\
\hline $\mathrm{Na}_{2} \mathrm{O}$ & 0.031 & 0.030 & 0.026 & 0.017 & 0.007 & 0.000 & 0.168 & 0.183 \\
\hline $\mathrm{K}_{2} \mathrm{O}$ & 0.015 & 0.008 & 0.000 & 0.000 & 0.016 & 0.008 & 0.000 & 0.019 \\
\hline Total & 99.210 & 99.130 & 98.310 & 98.180 & 99.280 & 98.720 & 98.800 & 98.820 \\
\hline \multicolumn{9}{|c|}{ Cátions para 6 oxigênios } \\
\hline Si & 1.971 & 1.997 & 1.988 & 2.064 & 1.984 & 1.978 & 1.983 & 1.977 \\
\hline $\mathrm{Al}^{\mathrm{IV}}$ & 0.019 & 0.003 & 0.012 & 0.000 & 0.016 & 0.020 & 0.017 & 0.023 \\
\hline $\mathrm{Fe}^{3+}$ & 0.009 & 0.000 & 0.000 & 0.000 & 0.000 & 0.002 & 0.000 & 0.000 \\
\hline $\mathrm{Al}^{\mathrm{Vl}}$ & 0.000 & 0.019 & 0.009 & 0.021 & 0.016 & 0.000 & 0.018 & 0.017 \\
\hline $\mathrm{Ti}$ & 0.002 & 0.002 & 0.002 & 0.004 & 0.002 & 0.003 & 0.004 & 0.005 \\
\hline $\mathrm{Fe}^{3+}$ & 0.027 & 0.000 & 0.000 & 0.000 & 0.000 & 0.015 & 0.003 & 0.010 \\
\hline $\mathrm{Fe}^{2+}$ & 0.009 & 0.001 & 0.001 & 0.015 & 0.044 & 0.065 & 0.312 & 0.296 \\
\hline $\mathrm{Cr}$ & 0.001 & 0.000 & 0.001 & 0.001 & 0.000 & 0.001 & 0.000 & 0.000 \\
\hline $\mathrm{Mg}$ & 0.961 & 0.978 & 0.987 & 0.959 & 0.937 & 0.916 & 0.663 & 0.672 \\
\hline Mg & 0.000 & 0.000 & 0.000 & 0.000 & 0.000 & 0.000 & 0.000 & 0.000 \\
\hline $\mathrm{Fe}^{2+}$ & 0.925 & 0.936 & 0.934 & 0.876 & 0.930 & 0.929 & 0.137 & 0.129 \\
\hline Mn & 0.023 & 0.018 & 0.018 & 0.015 & 0.024 & 0.027 & 0.011 & 0.010 \\
\hline $\mathrm{Ca}$ & 0.049 & 0.044 & 0.046 & 0.044 & 0.045 & 0.044 & 0.839 & 0.847 \\
\hline $\mathrm{Na}$ & 0.002 & 0.002 & 0.002 & 0.001 & 0.001 & 0.000 & 0.013 & 0.014 \\
\hline K & 0.001 & 0.000 & 0.000 & 0.000 & 0.001 & 0.000 & 0.000 & 0.001 \\
\hline Wo & 2.445 & 2.216 & 2.308 & 2.294 & 2.258 & 2.191 & 42.715 & 43.125 \\
\hline EN & 47.958 & 49.475 & 49.681 & 50.244 & 47.337 & 45.841 & 33.725 & 34.228 \\
\hline FS & 49.597 & 48.309 & 48.011 & 47.462 & 50.405 & 51.967 & 23.560 & 22.647 \\
\hline JD & 0.000 & 0.229 & 0.199 & 0.135 & 0.054 & 0.000 & 1.078 & 0.862 \\
\hline $\mathrm{AE}$ & 0.238 & 0.000 & 0.000 & 0.000 & 0.000 & 0.000 & 0.185 & 0.515 \\
\hline $\mathrm{mg} \#$ & 0.498 & 0.511 & 0.514 & 0.518 & 0.490 & 0.475 & 0.595 & 0.607 \\
\hline
\end{tabular}

$\mathrm{Fe}^{2+}$ e $\mathrm{Fe}^{3+}$ calculados por estequeometria; $\mathrm{Wo}=\mathrm{Ca} ; \mathrm{En}=\mathrm{Mg} ; \mathrm{Fs}=\mathrm{Fe}^{2+}+\mathrm{Fe}^{3+}+\mathrm{Mn}$ $\mathrm{mg} \#=100 *\left[\mathrm{Mg} /\left(\mathrm{Mg}+\mathrm{Fe}^{2+}+\mathrm{Fe}^{3+}\right)\right]$

c: centro; i: zona intermediária; b: borda

feno: fenocristal; mfeno:microfenocristal; idio: idiomórfico; sub-idio: sub-idiomórfico; xeno: xenomórfico;

incl: inclusão; frag: fragmentado; cc: concentração; pq: pequeno; gde: grande

plag: plagioclásio; bio: biotita 
ANEXO V - Tabelas 3.

Análise química dos piroxênios

UFRI

Amostra: PUL-20A

\begin{tabular}{|c|c|c|}
\hline análise & $\begin{array}{l}\quad \text { PXn.5C } \\
\text { cristal sub-ido } \\
\text { aparente/e } \\
\text { zonado } \\
\text { CENTRO }\end{array}$ & $\begin{array}{c}\text { PXn.5B } \\
\text { idem BORDA }\end{array}$ \\
\hline $\mathrm{SiO}_{2}$ & 50.599 & 50.796 \\
\hline $\mathrm{TiO}_{2}$ & 0.112 & 0.061 \\
\hline $\mathrm{Al}_{2} \mathrm{O}_{3}$ & 0.542 & 0.421 \\
\hline $\mathrm{FeO}$ & 29.517 & 29.794 \\
\hline $\mathrm{Fe}_{2} \mathrm{O}_{3}$ & 0.000 & 0.000 \\
\hline $\mathrm{Cr}_{2} \mathrm{O}_{3}$ & 0.000 & 0.000 \\
\hline $\mathrm{MnO}$ & 0.718 & 0.793 \\
\hline $\mathrm{MgO}$ & 15.919 & 15.212 \\
\hline $\mathrm{CaO}$ & 1.028 & 1.007 \\
\hline $\mathrm{Na}_{2} \mathrm{O}$ & 0.012 & 0.001 \\
\hline $\mathrm{K}_{2} \mathrm{O}$ & 0.020 & 0.000 \\
\hline Total & 98.470 & 98.090 \\
\hline $\mathrm{Si}$ & 1.994 & 2.018 \\
\hline $\mathrm{Al}^{\mathrm{IV}}$ & 0.006 & 0.000 \\
\hline $\mathrm{Fe}^{3+}$ & 0.000 & 0.000 \\
\hline $\mathrm{Al}^{\mathrm{VI}}$ & 0.019 & 0.020 \\
\hline $\mathrm{Ti}$ & 0.003 & 0.002 \\
\hline $\mathrm{Fe}^{3+}$ & 0.000 & 0.000 \\
\hline $\mathrm{Fe}^{2+}$ & 0.042 & 0.078 \\
\hline $\mathrm{Cr}$ & 0.000 & 0.000 \\
\hline $\mathrm{Mg}$ & 0.935 & 0.901 \\
\hline $\mathrm{Mg}$ & 0.000 & 0.000 \\
\hline $\mathrm{Fe}^{2+}$ & 0.931 & 0.912 \\
\hline $\mathrm{Mn}$ & 0.024 & 0.027 \\
\hline $\mathrm{Ca}$ & 0.043 & 0.043 \\
\hline $\mathrm{Na}$ & 0.001 & 0.000 \\
\hline $\mathrm{K}$ & 0.001 & 0.000 \\
\hline Wo & 2.197 & 2.186 \\
\hline EN & 47.344 & 45.957 \\
\hline FS & 50.459 & 51.856 \\
\hline $\mathrm{JD}$ & 0.093 & 0.008 \\
\hline $\mathrm{AE}$ & 0.000 & 0.000 \\
\hline $\mathrm{mg} \#$ & 0.490 & 0.476 \\
\hline
\end{tabular}

PUL-38A

\begin{tabular}{|c|c|c|c|c|}
\hline $\begin{array}{l}\text { OPX.01 } \\
\text { xeno c/ inclus/ } \\
\text { bordas ox }\end{array}$ & $\begin{array}{l}\text { OPX.07.1 } \\
\text { feno }(E N) \text { em } \\
\text { cc de } p q \\
\text { mfeno } p x\end{array}$ & $\begin{array}{l}\text { OPX.07.2 } \\
(F S)\end{array}$ & $\begin{array}{r}\text { OPX.08 } \\
\text { xeno } \mathrm{c} / \mathrm{incl}\end{array}$ & $\begin{array}{l}\text { OPX.9.1 } \\
\text { mfeno idio }\end{array}$ \\
\hline 50.849 & 51.242 & 51.224 & 50.946 & 50.831 \\
\hline 0.134 & 0.212 & 0.078 & 0.051 & 0.147 \\
\hline 0.466 & 3.930 & 0.476 & 0.448 & 0.419 \\
\hline 29.945 & 19.422 & 29.874 & 31.010 & 30.668 \\
\hline 0.000 & 0.000 & 0.000 & 0.000 & 0.000 \\
\hline 0.042 & 0.287 & 0.014 & 0.034 & 0.000 \\
\hline 0.590 & 0.345 & 0.635 & 0.715 & 0.752 \\
\hline 16.697 & 23.906 & 16.817 & 16.097 & 16.185 \\
\hline 1.209 & 1.151 & 1.171 & 1.023 & 1.043 \\
\hline 0.026 & 0.029 & 0.012 & 0.019 & 0.000 \\
\hline 0.008 & 0.028 & 0.000 & 0.000 & 0.004 \\
\hline 99.970 & 100.550 & 100.300 & 100.340 & 100.050 \\
\hline
\end{tabular}

Cátions para 6 oxigênios

\begin{tabular}{rrrrr}
1.969 & 1.868 & 1.975 & 1.975 & 1.975 \\
0.021 & 0.132 & 0.022 & 0.020 & 0.019 \\
0.010 & 0.000 & 0.003 & 0.005 & 0.006 \\
& & & & \\
0.000 & 0.036 & 0.000 & 0.000 & 0.000 \\
0.004 & 0.006 & 0.002 & 0.001 & 0.004 \\
0.025 & 0.079 & 0.020 & 0.023 & 0.017 \\
0.007 & 0.000 & 0.010 & 0.045 & 0.041 \\
0.001 & 0.008 & 0.000 & 0.001 & 0.000 \\
0.964 & 0.871 & 0.967 & 0.930 & 0.937 \\
& & & & \\
0.000 & 0.428 & 0.000 & 0.000 & 0.000 \\
0.928 & 0.513 & 0.930 & 0.933 & 0.932 \\
0.019 & 0.011 & 0.021 & 0.023 & 0.025 \\
0.050 & 0.045 & 0.048 & 0.042 & 0.043 \\
0.002 & 0.002 & 0.001 & 0.001 & 0.000 \\
0.000 & 0.001 & 0.000 & 0.000 & 0.000 \\
& & & & \\
2.504 & 2.309 & 2.420 & 2.123 & 2.169 \\
48.118 & 66.731 & 48.355 & 46.477 & 46.823 \\
49.377 & 30.960 & 49.225 & 51.400 & 51.008 \\
0.000 & 0.069 & 0.000 & 0.000 & 0.000 \\
0.198 & 0.150 & 0.091 & 0.145 & 0.000 \\
0.498 & 0.687 & 0.501 & 0.480 & 0.485 \\
\hline & & & &
\end{tabular}

$\mathrm{Fe}^{2+}$ e $\mathrm{Fe}^{3+}$ calculados por estequeometria; $\mathrm{Wo}=\mathrm{Ca} ; \mathrm{En}=\mathrm{Mg} ; \mathrm{Fs}=\mathrm{Fe}^{\mathrm{L}+}+\mathrm{Fe}^{3+}+\mathrm{Mn}$ $\mathrm{mg} \#=100 *\left[\mathrm{Mg} /\left(\mathrm{Mg}+\mathrm{Fe}^{2+}+\mathrm{Fe}^{3+}\right)\right]$

c: centro; i: zona intermediária; b: borda

feno: fenocristal; mfeno:microfenocristal; idio: idiomórfico; sub-idio: sub-idiomórfico; xeno: xenomórfico; incl: inclusão; frag: fragmentado; cc: concentração; pq: pequeno; gde: grande plag: plagioclásio; bio: biotita 
ANEXO V - Tabelas 3.

Análise química dos piroxênios

UFRI

UFRS

Amostra: PUL-38A

\begin{tabular}{llccll}
\hline OPX.9.2 & $\begin{array}{c}\text { OPX.13 } \\
\text { fenólise }\end{array}$ & $\begin{array}{c}\text { OPX.17 } \\
\text { feno sub- } \\
\text { idiom c/peq } \\
\text { incl }\end{array}$ & & $\begin{array}{c}\text { OPX.71.1 } \\
\text { feno sub- } \\
\text { idio em borda } \\
\text { de feno } 7.3\end{array}$ & $\begin{array}{l}\text { CPX.71.2 } \\
\text { cristal sub-idio feno xeno } \\
\text { em borda de } \\
\text { feno } 7.3\end{array}$ \\
\hline
\end{tabular}

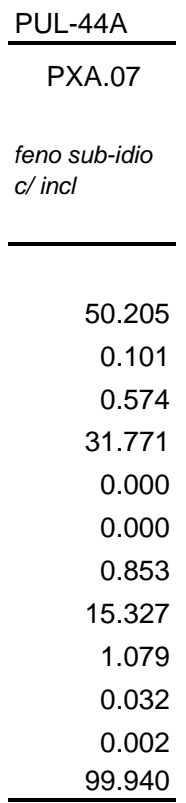

\begin{tabular}{lrrrrrr}
$\mathrm{SiO}_{2}$ & 50.551 & 50.937 & 51.027 & 50.527 & 52.043 & 49.627 \\
$\mathrm{TiO}_{2}$ & 0.101 & 0.115 & 0.023 & 0.131 & 0.202 & 0.196 \\
$\mathrm{Al}_{2} \mathrm{O}_{3}$ & 0.450 & 0.474 & 0.479 & 0.547 & 0.757 & 2.871 \\
$\mathrm{FeO}$ & 30.627 & 29.956 & 30.291 & 29.567 & 12.886 & 28.908 \\
$\mathrm{Fe}_{2} \mathrm{O}_{3}$ & 0.000 & 0.000 & 0.000 & 0.000 & 0.000 & 0.000 \\
$\mathrm{Cr}_{2} \mathrm{O}_{3}$ & 0.000 & 0.034 & 0.000 & 0.012 & 0.021 & 0.035 \\
$\mathrm{MnO}$ & 0.638 & 0.836 & 0.488 & 0.684 & 0.257 & 0.590 \\
$\mathrm{MgO}$ & 16.174 & 15.941 & 16.701 & 16.262 & 12.286 & 16.346 \\
$\mathrm{CaO}$ & 1.143 & 1.164 & 1.104 & 1.016 & 20.522 & 1.150 \\
$\mathrm{Na} \mathrm{N}_{2} \mathrm{O}$ & 0.006 & 0.027 & 0.020 & 0.000 & 0.199 & 0.073 \\
$\mathrm{~K}$ & 0.000 & 0.016 & 0.007 & 0.016 & 0.000 & 0.050 \\
$\mathrm{Total}$ & 99.690 & 99.500 & 100.140 & 98.760 & 99.170 & 99.850 \\
\hline & & & & & &
\end{tabular}

205

0.574

.000

0.000

327

.079

0.032

99.940

Cátions para 6 oxigênios

\begin{tabular}{|c|c|c|c|c|c|c|c|}
\hline $\mathrm{Si}$ & 1.970 & 1.989 & 1.972 & 1.983 & 1.987 & 1.915 & 1.963 \\
\hline $\mathrm{Al}^{\mathrm{IV}}$ & 0.021 & 0.011 & 0.022 & 0.017 & 0.013 & 0.085 & 0.026 \\
\hline $\mathrm{Fe}^{3+}$ & 0.010 & 0.000 & 0.006 & 0.000 & 0.000 & 0.000 & 0.011 \\
\hline $\mathrm{Al}^{\mathrm{Vl}}$ & 0.000 & 0.010 & 0.000 & 0.008 & 0.021 & 0.045 & 0.000 \\
\hline $\mathrm{Ti}$ & 0.003 & 0.003 & 0.001 & 0.004 & 0.006 & 0.006 & 0.003 \\
\hline $\mathrm{Fe}^{3+}$ & 0.025 & 0.000 & 0.028 & 0.002 & 0.000 & 0.035 & 0.034 \\
\hline $\mathrm{Fe}^{2+}$ & 0.033 & 0.057 & 0.009 & 0.035 & 0.274 & 0.000 & 0.070 \\
\hline $\mathrm{Cr}$ & 0.000 & 0.001 & 0.000 & 0.000 & 0.001 & 0.001 & 0.000 \\
\hline $\mathrm{Mg}$ & 0.939 & 0.928 & 0.962 & 0.951 & 0.699 & 0.913 & 0.893 \\
\hline $\mathrm{Mg}$ & 0.000 & 0.000 & 0.000 & 0.000 & 0.000 & 0.027 & 0.000 \\
\hline $\mathrm{Fe}^{2+}$ & 0.931 & 0.921 & 0.936 & 0.934 & 0.138 & 0.898 & 0.924 \\
\hline $\mathrm{Mn}$ & 0.021 & 0.028 & 0.016 & 0.023 & 0.008 & 0.019 & 0.028 \\
\hline $\mathrm{Ca}$ & 0.048 & 0.049 & 0.046 & 0.043 & 0.839 & 0.048 & 0.045 \\
\hline $\mathrm{Na}$ & 0.000 & 0.002 & 0.001 & 0.000 & 0.015 & 0.005 & 0.002 \\
\hline K & 0.000 & 0.001 & 0.000 & 0.001 & 0.000 & 0.002 & 0.000 \\
\hline WO & 2.378 & 2.456 & 2.282 & 2.150 & 42.863 & 2.451 & 2.254 \\
\hline EN & 46.828 & 46.806 & 48.040 & 47.875 & 35.705 & 48.469 & 44.542 \\
\hline FS & 50.794 & 50.737 & 49.677 & 49.975 & 21.432 & 49.080 & 53.204 \\
\hline $\mathrm{JD}$ & 0.000 & 0.206 & 0.000 & 0.000 & 1.482 & 0.323 & 0.000 \\
\hline$A E$ & 0.046 & 0.000 & 0.152 & 0.000 & 0.000 & 0.247 & 0.247 \\
\hline $\mathrm{mg} \#$ & 0.485 & 0.487 & 0.496 & 0.495 & 0.629 & 0.502 & 0.462 \\
\hline
\end{tabular}

$\mathrm{Fe}^{2+}$ e $\mathrm{Fe}^{3+}$ calculados por estequeometria; $\mathrm{Wo}=\mathrm{Ca} ; \mathrm{En}=\mathrm{Mg} ; \mathrm{Fs}=\mathrm{Fe}^{2+}+\mathrm{Fe}^{3+}+\mathrm{Mn}$ $\mathrm{mg} \#=100 *\left[\mathrm{Mg} /\left(\mathrm{Mg}+\mathrm{Fe}^{2+}+\mathrm{Fe}^{\zeta+}\right)\right]$

c: centro; i: zona intermediária; b: borda

feno: fenocristal; mfeno:microfenocristal; idio: idiomórfico; sub-idio: sub-idiomórfico; xeno: xenomórfico; incl: inclusão; frag: fragmentado; cc: concentração; pq: pequeno; gde: grande plag: plagioclásio; bio: biotita 
ANEXO V - Tabelas 3.

Análise química dos piroxênios

UFRS

Amostra: PUL-44A

\begin{tabular}{|c|c|c|c|c|c|c|c|c|}
\hline análise & PXA.13 & PXA.16 & $\begin{array}{l}\text { PXA.17 } \\
\text { gde feno sub- } \\
\text { idio }\end{array}$ & $\begin{array}{l}\quad \text { PXN.05 } \\
\text { sub-idio. } \\
\text { fraturado e } \\
\text { oxidado }\end{array}$ & $\begin{array}{l}\quad \text { PXA.18C } \\
\text { gde feno sub- } \\
\text { idio c/ centro } \\
\text { reabsor }\end{array}$ & PXA.18B & $\begin{array}{l}\text { PXA.19 } \\
\text { mfeno sub- } \\
\text { idio. C/ incl de } \\
\text { bio e plag }\end{array}$ & $\begin{array}{l}\quad \text { PXA.20 } \\
\text { mfeno idio c/ } \\
\text { incl e borda } \\
\text { intercresc c/ } \\
\text { bio e plag }\end{array}$ \\
\hline $\mathrm{SiO}_{2}$ & 51.966 & 51.544 & 50.949 & 51.100 & 50.570 & 50.706 & 50.399 & 51.414 \\
\hline $\mathrm{TiO}_{2}$ & 0.252 & 0.155 & 0.078 & 0.051 & 0.143 & 0.110 & 0.097 & 0.161 \\
\hline $\mathrm{Al}_{2} \mathrm{O}_{3}$ & 0.822 & 0.858 & 0.389 & 0.355 & 0.739 & 0.429 & 0.587 & 1.079 \\
\hline $\mathrm{FeO}$ & 13.830 & 13.404 & 30.679 & 30.709 & 30.280 & 31.074 & 31.146 & 12.571 \\
\hline $\mathrm{Fe}_{2} \mathrm{O}_{3}$ & 0.000 & 0.000 & 0.000 & 0.000 & 0.000 & 0.000 & 0.000 & 0.000 \\
\hline $\mathrm{Cr}_{2} \mathrm{O}_{3}$ & & 0.000 & 0.004 & 0.000 & 0.000 & 0.000 & & \\
\hline $\mathrm{MnO}$ & 0.325 & 0.409 & 0.808 & 0.806 & 0.638 & 0.838 & 0.839 & 0.265 \\
\hline $\mathrm{MgO}$ & 11.946 & 11.886 & 15.681 & 15.656 & 16.352 & 15.407 & 15.193 & 12.470 \\
\hline $\mathrm{CaO}$ & 21.525 & 21.667 & 1.248 & 1.109 & 0.932 & 1.157 & 1.227 & 21.251 \\
\hline $\mathrm{Na}_{2} \mathrm{O}$ & 0.229 & 0.190 & 0.012 & 0.000 & 0.000 & 0.000 & 0.035 & 0.220 \\
\hline $\mathrm{K}_{2} \mathrm{O}$ & 0.000 & 0.000 & 0.007 & 0.006 & 0.008 & 0.009 & 0.002 & 0.000 \\
\hline Total & & 100.110 & 99.860 & 99.790 & 99.660 & 99.730 & & \\
\hline \multicolumn{9}{|c|}{ Cátions para 6 oxigênios } \\
\hline $\mathrm{Si}$ & 1.956 & 1.954 & 1.987 & 1.995 & 1.968 & 1.984 & 1.977 & 1.953 \\
\hline $\mathrm{Al}^{\mathrm{IV}}$ & 0.036 & 0.038 & 0.013 & 0.005 & 0.032 & 0.016 & 0.023 & 0.047 \\
\hline $\mathrm{Fe}^{3+}$ & 0.008 & 0.008 & 0.000 & 0.000 & 0.000 & 0.000 & 0.000 & 0.000 \\
\hline $\mathrm{Al}^{\mathrm{VI}}$ & 0.000 & 0.000 & 0.005 & 0.011 & 0.002 & 0.004 & 0.004 & 0.001 \\
\hline $\mathrm{Ti}$ & 0.007 & 0.004 & 0.002 & 0.001 & 0.004 & 0.003 & 0.003 & 0.005 \\
\hline $\mathrm{Fe}^{3+}$ & 0.047 & 0.051 & 0.004 & 0.000 & 0.023 & 0.005 & 0.015 & 0.054 \\
\hline $\mathrm{Fe}^{2+}$ & 0.276 & 0.273 & 0.076 & 0.076 & 0.023 & 0.088 & 0.089 & 0.235 \\
\hline $\mathrm{Cr}$ & 0.000 & 0.000 & 0.000 & 0.000 & 0.000 & 0.000 & 0.000 & 0.000 \\
\hline $\mathrm{Mg}$ & 0.670 & 0.672 & 0.912 & 0.911 & 0.949 & 0.899 & 0.889 & 0.706 \\
\hline $\mathrm{Mg}$ & 0.000 & 0.000 & 0.000 & 0.000 & 0.000 & 0.000 & 0.000 & 0.000 \\
\hline $\mathrm{Fe}^{2+}$ & 0.105 & 0.093 & 0.920 & 0.927 & 0.940 & 0.923 & 0.918 & 0.111 \\
\hline $\mathrm{Mn}$ & 0.010 & 0.013 & 0.027 & 0.027 & 0.021 & 0.028 & 0.028 & 0.009 \\
\hline $\mathrm{Ca}$ & 0.868 & 0.880 & 0.052 & 0.046 & 0.039 & 0.049 & 0.052 & 0.865 \\
\hline $\mathrm{Na}$ & 0.017 & 0.014 & 0.001 & 0.000 & 0.000 & 0.000 & 0.003 & 0.016 \\
\hline $\mathrm{K}$ & 0.000 & 0.000 & 0.000 & 0.000 & 0.000 & 0.000 & 0.000 & 0.000 \\
\hline Wo & 43.751 & 44.227 & 2.619 & 2.335 & 1.949 & 2.435 & 2.592 & 43.705 \\
\hline EN & 33.785 & 33.757 & 45.787 & 45.861 & 47.575 & 45.120 & 44.654 & 35.684 \\
\hline FS & 22.464 & 22.016 & 51.594 & 51.805 & 50.476 & 52.445 & 52.754 & 20.611 \\
\hline $\mathrm{JD}$ & 0.000 & 0.000 & 0.049 & 0.000 & 0.000 & 0.000 & 0.060 & 0.024 \\
\hline $\mathrm{AE}$ & 1.703 & 1.426 & 0.042 & 0.000 & 0.000 & 0.000 & 0.209 & 1.632 \\
\hline $\mathrm{mg} \#$ & 0.606 & 0.613 & 0.477 & 0.476 & 0.490 & 0.469 & 0.465 & 0.638 \\
\hline
\end{tabular}

$\mathrm{Fe}^{2+}$ e $\mathrm{Fe}^{3+}$ calculados por estequeometria; $\mathrm{Wo}=\mathrm{Ca} ; \mathrm{En}=\mathrm{Mg} ; \mathrm{Fs}=\mathrm{Fe}^{2+}+\mathrm{Fe}^{3+}+\mathrm{Mn}$ $\mathrm{mg} \#=100 *\left[\mathrm{Mg} /\left(\mathrm{Mg}+\mathrm{Fe}^{2+}+\mathrm{Fe}^{\zeta+}\right)\right]$

c: centro; i: zona intermediária; b: borda

feno: fenocristal; mfeno:microfenocristal; idio: idiomórfico; sub-idio: sub-idiomórfico; xeno: xenomórfico;

incl: inclusão; frag: fragmentado; cc: concentração; pq: pequeno; gde: grande

plag: plagioclásio; bio: biotita 
ANEXO V - Tabelas 3.

Análise química dos piroxênios

UFRS

Amostra: PUL-44A

\begin{tabular}{|c|c|c|c|c|c|c|c|c|}
\hline & PXA.22 & PXA.24 & PXN.6 & PXN.8 & PXN.09 & PXN.10.1 & PXN.12 & PXN.15 \\
\hline análise & $\begin{array}{l}\text { frag de gde } \\
\text { fenocr }\end{array}$ & $\begin{array}{l}\text { mfeno idio e } \\
\text { frat }\end{array}$ & $\begin{array}{l}\text { feno sub- } \\
\text { idiom }\end{array}$ & $\begin{array}{l}\text { feno sub-idio } \\
\text { c/ fina borda } \\
\text { ox }\end{array}$ & $\begin{array}{l}\text { xeno c/ incl de } \\
\text { plag (centro) e } \\
\text { bio (bordas) }\end{array}$ & $\begin{array}{l}\text { feno idio c/ } \\
\text { incl de microl } \\
\text { de plag e } \\
\text { oxidos }\end{array}$ & idiom c/ incl & $\begin{array}{l}\text { sub-idio a } \\
\text { xeno } \\
\text { intercresc c/ } \\
\text { plag }\end{array}$ \\
\hline
\end{tabular}

\begin{tabular}{lrrrrrrrr}
$\mathrm{SiO}_{2}$ & 50.296 & 51.037 & 51.693 & 51.546 & 51.352 & 51.737 & 51.822 & 50.758 \\
$\mathrm{TiO}_{2}$ & 0.078 & 0.106 & 0.138 & 0.177 & 0.107 & 0.064 & 0.118 & 0.121 \\
$\mathrm{Al}_{2} \mathrm{O}_{3}$ & 0.503 & 0.478 & 0.857 & 0.966 & 0.484 & 0.741 & 0.805 & 0.454 \\
$\mathrm{FeO}$ & 31.642 & 31.529 & 12.967 & 13.961 & 31.829 & 14.009 & 14.368 & 30.847 \\
$\mathrm{Fe}_{2} \mathrm{O}_{3}$ & 0.000 & 0.000 & 0.000 & 0.000 & 0.000 & 0.000 & 0.000 & 0.000 \\
$\mathrm{Cr}_{2} \mathrm{O}_{3}$ & 0.014 & 0.010 & 0.000 & 0.017 & 0.014 & 0.000 & 0.000 & 0.028 \\
$\mathrm{MnO}$ & 0.856 & 0.895 & 0.297 & 0.395 & 0.870 & 0.371 & 0.362 & 0.716 \\
$\mathrm{MgO}$ & 15.059 & 15.312 & 12.424 & 11.611 & 15.648 & 11.898 & 11.667 & 15.623 \\
$\mathrm{CaO}$ & 1.145 & 1.164 & 21.061 & 20.362 & 0.854 & 20.302 & 20.559 & 1.057 \\
$\mathrm{Na}{ }_{2} \mathrm{O}$ & 0.009 & 0.018 & 0.195 & 0.195 & 0.018 & 0.201 & 0.214 & 0.023 \\
$\mathrm{~K}_{2} \mathrm{O}$ & 0.009 & 0.000 & 0.000 & 0.010 & 0.000 & 0.000 & 0.011 & 0.008 \\
$\mathrm{Total}$ & 99.610 & 100.550 & 99.630 & 99.240 & 101.180 & 99.320 & 99.930 & 99.640 \\
\hline
\end{tabular}

\section{Cátions para 6 oxigênios}

\begin{tabular}{lrrrrrrrr}
$\mathrm{Si}$ & 1.975 & 1.984 & 1.962 & 1.976 & 1.982 & 1.979 & 1.974 & 1.985 \\
$\mathrm{Al}^{\mathrm{V}}$ & 0.023 & 0.016 & 0.038 & 0.024 & 0.018 & 0.021 & 0.026 & 0.015 \\
$\mathrm{Fe}^{3+}$ & 0.001 & 0.000 & 0.000 & 0.000 & 0.000 & 0.000 & 0.000 & 0.000 \\
& & & & & & & & \\
$\mathrm{Al}^{\mathrm{VI}}$ & 0.000 & 0.005 & 0.001 & 0.019 & 0.004 & 0.012 & 0.010 & 0.006 \\
$\mathrm{Ti}$ & 0.002 & 0.003 & 0.004 & 0.005 & 0.003 & 0.002 & 0.003 & 0.004 \\
$\mathrm{Fe}^{3+}$ & 0.021 & 0.006 & 0.043 & 0.009 & 0.009 & 0.020 & 0.026 & 0.003 \\
$\mathrm{Fe}^{2+}$ & 0.095 & 0.098 & 0.249 & 0.303 & 0.083 & 0.288 & 0.298 & 0.076 \\
$\mathrm{Cr}$ & 0.000 & 0.000 & 0.000 & 0.001 & 0.000 & 0.000 & 0.000 & 0.001 \\
$\mathrm{Mg}$ & 0.882 & 0.887 & 0.703 & 0.663 & 0.900 & 0.679 & 0.662 & 0.911 \\
& & & & & & & & \\
$\mathrm{Mg}$ & 0.000 & 0.000 & 0.000 & 0.000 & 0.000 & 0.000 & 0.000 & 0.000 \\
$\mathrm{Fe}$ & 0.922 & 0.921 & 0.119 & 0.136 & 0.935 & 0.141 & 0.133 & 0.930 \\
$\mathrm{Mn}$ & 0.028 & 0.029 & 0.010 & 0.013 & 0.028 & 0.012 & 0.012 & 0.024 \\
$\mathrm{Ca}$ & 0.048 & 0.048 & 0.857 & 0.836 & 0.035 & 0.832 & 0.839 & 0.044 \\
$\mathrm{Na}$ & 0.001 & 0.001 & 0.014 & 0.014 & 0.001 & 0.015 & 0.016 & 0.002 \\
$\mathrm{~K}$ & 0.000 & 0.000 & 0.000 & 0.000 & 0.000 & 0.000 & 0.001 & 0.000 \\
& & & & & & & & \\
$\mathrm{WO}$ & 2.412 & 2.436 & 43.243 & 42.664 & 1.773 & 42.221 & 42.571 & 2.228 \\
$\mathrm{EN}$ & 44.137 & 44.584 & 35.493 & 33.850 & 45.210 & 34.428 & 33.614 & 45.823 \\
$\mathrm{FS}$ & 53.451 & 52.980 & 21.264 & 23.487 & 53.016 & 23.350 & 23.815 & 51.949 \\
$\mathrm{JD}$ & 0.000 & 0.065 & 0.024 & 0.999 & 0.040 & 0.587 & 0.433 & 0.112 \\
$\mathrm{AE}$ & 0.069 & 0.071 & 1.436 & 0.465 & 0.095 & 0.919 & 1.167 & 0.064 \\
$\mathrm{mg} \#$ & 0.459 & 0.464 & 0.631 & 0.597 & 0.467 & 0.602 & 0.592 & 0.474 \\
\hline & & & & & & & &
\end{tabular}

$\mathrm{Fe}^{2+}$ e $\mathrm{Fe}^{3+}$ calculados por estequeometria; $\mathrm{Wo}=\mathrm{Ca} ; \mathrm{En}=\mathrm{Mg} ; \mathrm{Fs}=\mathrm{Fe}^{2+}+\mathrm{Fe}^{3+}+\mathrm{Mn}$ $\mathrm{mg} \#=100 *\left[\mathrm{Mg} /\left(\mathrm{Mg}+\mathrm{Fe}^{2+}+\mathrm{Fe}^{3+}\right)\right]$

c: centro; i: zona intermediária; b: borda

feno: fenocristal; mfeno:microfenocristal; idio: idiomórfico; sub-idio: sub-idiomórfico; xeno: xenomórfico; incl: inclusão; frag: fragmentado; cc: concentração; pq: pequeno; gde: grande plag: plagioclásio; bio: biotita 
ANEXO V - Tabelas 3.

\section{Análise química dos piroxênios}

UFRS

Amostra: PUL-44A

\begin{tabular}{|c|c|}
\hline análise & $\begin{array}{l}\text { PXA.01 } \\
\text { PERTENCENTE A } \\
\text { LITICO xeno } \\
\text { arredondado c/ incl } \\
\text { de bio }\end{array}$ \\
\hline $\mathrm{SiO}_{2}$ & 51.218 \\
\hline $\mathrm{TiO}_{2}$ & 0.023 \\
\hline $\mathrm{Al}_{2} \mathrm{O}_{3}$ & 0.333 \\
\hline $\mathrm{FeO}$ & 32.072 \\
\hline $\mathrm{Fe}_{2} \mathrm{O}_{3}$ & 0.000 \\
\hline $\mathrm{Cr}_{2} \mathrm{O}_{3}$ & 0.000 \\
\hline $\mathrm{MnO}$ & 1.040 \\
\hline $\mathrm{MgO}$ & 15.354 \\
\hline $\mathrm{CaO}$ & 1.086 \\
\hline $\mathrm{Na}_{2} \mathrm{O}$ & 0.017 \\
\hline $\mathrm{K}_{2} \mathrm{O}$ & 0.000 \\
\hline Total & 101.140 \\
\hline
\end{tabular}

\begin{tabular}{lr}
$\mathrm{Si}$ & 1.981 \\
$\mathrm{Al}^{\mathrm{IV}}$ & 0.015 \\
$\mathrm{Fe}^{3+}$ & 0.004 \\
& \\
$\mathrm{Al}^{\mathrm{VI}}$ & 0.000 \\
$\mathrm{Ti}^{3+}$ & 0.001 \\
$\mathrm{Fe}^{3+}$ & 0.019 \\
$\mathrm{Fe}^{2+}$ & 0.095 \\
$\mathrm{Cr}$ & 0.000 \\
$\mathrm{Mg}$ & 0.885 \\
& \\
$\mathrm{Mg}$ & 0.000 \\
$\mathrm{Fe}$ & 0.920 \\
$\mathrm{Mn}$ & 0.034 \\
$\mathrm{Ca}$ & 0.045 \\
$\mathrm{Na}$ & 0.001 \\
$\mathrm{~K}$ & 0.000 \\
& \\
$\mathrm{WO}$ & 2.248 \\
$\mathrm{EN}$ & 44.226 \\
$\mathrm{FS}$ & 53.526 \\
$\mathrm{JD}$ & 0.000 \\
$\mathrm{AE}$ & 0.129 \\
$\mathrm{mg} \#$ & 0.460 \\
\hline & \\
&
\end{tabular}

UFRS

\begin{tabular}{|c|c|c|c|c|}
\hline PXA.10 & PXA.45 & CPX.11 & CPX.12 & PXA.15 \\
\hline $\begin{array}{l}\text { feno sub-idio. } \\
\text { frat }\end{array}$ & $\begin{array}{l}\text { ENS micro- } \\
\text { feno idio cl } \\
\text { incl e } \\
\text { fraturado }\end{array}$ & $\begin{array}{l}\text { mfeno sub- } \\
\text { idio c/ bordas } \\
\text { corroidas }\end{array}$ & mfeno idio & $\begin{array}{l}\text { ENS mfeno sub- } \\
\text { idio c/ bordas } \\
\text { arredond. Assoc a } \\
\text { cc maficos }\end{array}$ \\
\hline 50.732 & 52.857 & 51.267 & 51.461 & 53.913 \\
\hline 0.092 & 0.322 & 0.116 & 0.199 & 0.233 \\
\hline 0.469 & 0.645 & 0.854 & 0.847 & 1.729 \\
\hline 30.586 & 26.118 & 14.764 & 14.246 & 17.395 \\
\hline 0.000 & 0.000 & 0.000 & 0.000 & 0.000 \\
\hline 0.019 & 0.007 & & 0.026 & 0.014 \\
\hline 0.798 & 0.475 & 0.444 & 0.435 & 0.261 \\
\hline 16.074 & 19.809 & 11.553 & 11.400 & 25.021 \\
\hline 1.109 & 1.775 & 21.304 & 21.444 & 1.635 \\
\hline 0.013 & 0.032 & 0.194 & 0.192 & 0.051 \\
\hline 0.000 & 0.002 & 0.000 & 0.000 & 0.000 \\
\hline 99.890 & 102.040 & & 100.250 & 100.250 \\
\hline
\end{tabular}

Cátions para 6 oxigênios

\begin{tabular}{rrrrr}
1.974 & 1.965 & 1.944 & 1.956 & 1.959 \\
0.021 & 0.028 & 0.038 & 0.038 & 0.041 \\
0.004 & 0.007 & 0.018 & 0.006 & 0.000 \\
& & & & \\
0.000 & 0.000 & 0.000 & 0.000 & 0.033 \\
0.003 & 0.009 & 0.003 & 0.006 & 0.006 \\
0.021 & 0.019 & 0.064 & 0.046 & 0.000 \\
0.043 & 0.000 & 0.280 & 0.301 & 0.000 \\
0.001 & 0.000 & 0.000 & 0.001 & 0.000 \\
0.932 & 0.972 & 0.653 & 0.646 & 0.960 \\
& & & & \\
0.000 & 0.126 & 0.000 & 0.000 & 0.396 \\
0.926 & 0.786 & 0.106 & 0.099 & 0.529 \\
0.026 & 0.015 & 0.014 & 0.014 & 0.008 \\
0.046 & 0.071 & 0.865 & 0.873 & 0.064 \\
0.001 & 0.002 & 0.014 & 0.014 & 0.004 \\
0.000 & 0.000 & 0.000 & 0.000 & 0.000 \\
& & & & \\
2.311 & 3.543 & 43.254 & 43.970 & 3.255 \\
46.615 & 55.015 & 32.637 & 32.524 & 69.305 \\
51.074 & 41.442 & 24.110 & 23.506 & 27.440 \\
0.000 & 0.000 & 0.000 & 0.000 & 0.366 \\
0.099 & 0.234 & 1.465 & 1.443 & 0.000 \\
0.484 & 0.575 & 0.583 & 0.588 & 0.719 \\
\hline
\end{tabular}

$\mathrm{Fe}^{2+}$ e $\mathrm{Fe}^{3+}$ calculados por estequeometria; $\mathrm{Wo}=\mathrm{Ca} ; \mathrm{En}=\mathrm{Mg} ; \mathrm{Fs}=\mathrm{Fe}^{2+}+\mathrm{Fe}^{3+}+\mathrm{Mn}$ $\mathrm{mg} \#=100 *\left[\mathrm{Mg} /\left(\mathrm{Mg}+\mathrm{Fe}^{\alpha^{+}}+\mathrm{Fe}^{3+}\right)\right]$

c: centro; i: zona intermediária; b: borda

feno: fenocristal; mfeno:microfenocristal; idio: idiomórfico; sub-idio: sub-idiomórfico; xeno: xenomórfico; incl: inclusão; frag: fragmentado; cc: concentração; pq: pequeno; gde: grande plag: plagioclásio; bio: biotita 
ANEXO V - Tabelas 3.

Análise química dos piroxênios

UFRS

Amostra: PUL-44B

\begin{tabular}{|c|c|c|c|c|c|c|c|c|}
\hline análise & $\begin{array}{l}\text { feno idio da } \\
\text { matriz }\end{array}$ & $\begin{array}{l}\text { feno sub-idio. } \\
\text { Intercresc c/ } \\
\text { plag }\end{array}$ & $\begin{array}{l}\text { sub-idio. } \\
\text { pouco frat }\end{array}$ & $\begin{array}{l}\text { sub-idio. Frat c/ } \\
\text { bordas } \\
\text { corroidas ou } \\
\text { dissolv. }\end{array}$ & $\begin{array}{l}\text { feno xeno c/ } \\
\text { muitas incl e } \\
\text { fraturado. } \\
\text { CENTRO }\end{array}$ & idem. BORDA & feno idio & $\begin{array}{l}\text { feno idio cl } \\
\text { bordas corr e } \\
\text { incl na borda } \\
\text { de PXN.412 }\end{array}$ \\
\hline
\end{tabular}

\begin{tabular}{|c|c|c|c|c|c|c|c|c|}
\hline $\mathrm{TiO}_{2}$ & 0.230 & 0.138 & 0.103 & 0.309 & 0.262 & 0.103 & 0.069 & 0.255 \\
\hline $\mathrm{Al}_{2} \mathrm{O}_{3}$ & 0.501 & 1.017 & 0.751 & 0.843 & 0.535 & 0.468 & 0.894 & 2.062 \\
\hline $\mathrm{FeO}$ & 31.287 & 30.468 & 14.676 & 29.981 & 30.998 & 31.621 & 14.640 & 16.316 \\
\hline $\mathrm{Fe}_{2} \mathrm{O}_{3}$ & 0.000 & 0.000 & 0.000 & 0.000 & 0.000 & 0.000 & 0.000 & 0.000 \\
\hline $\mathrm{Cr}_{2} \mathrm{O}_{3}$ & 0.029 & 0.000 & 0.000 & 0.000 & 0.000 & 0.000 & 0.000 & 0.000 \\
\hline $\mathrm{MgO}$ & 15.511 & 15.701 & 11.486 & 16.316 & 16.029 & 14.843 & 11.180 & 25.827 \\
\hline $\mathrm{CaO}$ & 1.158 & 0.917 & 21.456 & 1.291 & 0.953 & 1.063 & 20.629 & 1.243 \\
\hline $\mathrm{Na}_{2} \mathrm{O}$ & 0.007 & 0.000 & 0.263 & 0.000 & 0.029 & 0.052 & 0.218 & 0.013 \\
\hline $\mathrm{K}_{2} \mathrm{O}$ & 0.008 & 0.013 & 0.000 & 0.016 & 0.001 & 0.023 & 0.021 & 0.000 \\
\hline
\end{tabular}

\begin{tabular}{|c|c|c|c|c|c|c|c|c|}
\hline \multicolumn{9}{|c|}{ Cátions para 6 oxigênios } \\
\hline $\mathrm{Si}$ & 1.969 & 1.980 & 1.945 & 1.963 & 1.966 & 1.982 & 1.959 & 1.947 \\
\hline $\mathrm{Al}^{\mathrm{IV}}$ & 0.023 & 0.020 & 0.034 & 0.037 & 0.024 & 0.018 & 0.041 & 0.053 \\
\hline $\mathrm{Fe}^{3+}$ & 0.008 & 0.000 & 0.021 & 0.000 & 0.009 & 0.000 & 0.001 & 0.000 \\
\hline $\mathrm{Al}^{\mathrm{VI}}$ & 0.000 & 0.026 & 0.000 & 0.001 & 0.000 & 0.004 & 0.000 & 0.036 \\
\hline $\mathrm{Ti}$ & 0.007 & 0.004 & 0.003 & 0.009 & 0.008 & 0.003 & 0.002 & 0.007 \\
\hline $\mathrm{Fe}^{3+}$ & 0.018 & 0.000 & 0.068 & 0.019 & 0.020 & 0.012 & 0.055 & 0.004 \\
\hline $\mathrm{Fe}^{2+}$ & 0.073 & 0.056 & 0.280 & 0.027 & 0.043 & 0.110 & 0.301 & 0.000 \\
\hline $\mathrm{Cr}$ & 0.001 & 0.000 & 0.000 & 0.000 & 0.000 & 0.000 & 0.000 & 0.000 \\
\hline $\mathrm{Mg}$ & 0.902 & 0.914 & 0.649 & 0.944 & 0.929 & 0.871 & 0.643 & 0.954 \\
\hline $\mathrm{Mg}$ & 0.000 & 0.000 & 0.000 & 0.000 & 0.000 & 0.000 & 0.000 & 0.448 \\
\hline $\mathrm{Fe}^{2+}$ & 0.922 & 0.939 & 0.095 & 0.927 & 0.936 & 0.918 & 0.116 & 0.493 \\
\hline $\mathrm{Mn}$ & 0.029 & 0.022 & 0.015 & 0.019 & 0.022 & 0.032 & 0.015 & 0.009 \\
\hline $\mathrm{Ca}$ & 0.048 & 0.038 & 0.871 & 0.054 & 0.040 & 0.045 & 0.852 & 0.048 \\
\hline $\mathrm{Na}$ & 0.001 & 0.000 & 0.019 & 0.000 & 0.002 & 0.004 & 0.016 & 0.001 \\
\hline $\mathrm{K}$ & 0.000 & 0.001 & 0.000 & 0.001 & 0.000 & 0.001 & 0.001 & 0.000 \\
\hline WO & 2.420 & 1.948 & 43.558 & 2.698 & 1.986 & 2.254 & 43.005 & 2.478 \\
\hline EN & 45.096 & 46.400 & 32.444 & 47.451 & 46.474 & 43.800 & 32.429 & 71.645 \\
\hline FS & 52.485 & 51.652 & 23.997 & 49.850 & 51.540 & 53.945 & 24.567 & 25.876 \\
\hline JD & 0.000 & 0.000 & 0.000 & 0.000 & 0.000 & 0.099 & 0.000 & 0.085 \\
\hline $\mathrm{AE}$ & 0.054 & 0.000 & 1.983 & 0.000 & 0.222 & 0.301 & 1.664 & 0.009 \\
\hline $\mathrm{mg} \#$ & 0.469 & 0.479 & 0.583 & 0.492 & 0.480 & 0.456 & 0.576 & 0.738 \\
\hline
\end{tabular}

$\mathrm{Fe}^{2+}$ e $\mathrm{Fe}^{3+}$ calculados por estequeometria; $\mathrm{Wo}=\mathrm{Ca} ; \mathrm{En}=\mathrm{Mg} ; \mathrm{Fs}=\mathrm{Fe}^{\mathrm{L+}}+\mathrm{Fe}^{\mathrm{s}^{+}}+\mathrm{Mn}$ $\mathrm{mg} \#=100 *\left[\mathrm{Mg} /\left(\mathrm{Mg}+\mathrm{Fe}^{2+}+\mathrm{Fe}^{3+}\right)\right]$

c: centro; i: zona intermediária; b: borda

feno: fenocristal; mfeno:microfenocristal; idio: idiomórfico; sub-idio: sub-idiomórfico; xeno: xenomórfico; incl: inclusão; frag: fragmentado; cc: concentração; pq: pequeno; gde: grande plag: plagioclásio; bio: biotita 
ANEXO V - Tabelas 3.

Análise química dos piroxênios

UFRS

Amostra: PUL-44B

\begin{tabular}{lrrr}
\hline análise & PXN.412 & PXN.42 & PXN.35 \\
descrição & mfeno idio & $\begin{array}{l}\text { feno c/incl de } \\
\text { ox e plag }\end{array}$ \\
\hline
\end{tabular}

\begin{tabular}{lrrr}
\hline & & & \\
$\mathrm{SiO}_{2}$ & 53.242 & 49.848 & 50.817 \\
$\mathrm{TiO}_{2}$ & 0.302 & 0.158 & 0.121 \\
$\mathrm{Al}_{2} \mathrm{O}_{3}$ & 2.243 & 0.969 & 0.693 \\
$\mathrm{FeO}$ & 17.792 & 30.748 & 30.834 \\
$\mathrm{Fe}_{2} \mathrm{O}_{3}$ & 0.000 & 0.000 & 0.000 \\
$\mathrm{Cr}_{2} \mathrm{O}_{3}$ & 0.000 & 0.000 & 0.000 \\
$\mathrm{MnO}$ & 0.319 & 0.638 & 0.621 \\
$\mathrm{MgO}$ & 25.242 & 15.666 & 16.337 \\
$\mathrm{CaO}$ & 1.313 & 1.211 & 1.038 \\
$\mathrm{Na}$ & 0.000 & 0.000 & 0.022 \\
$\mathrm{~K}_{2} \mathrm{O}$ & 0.012 & 0.023 & 0.000 \\
$\mathrm{Total}$ & 100.470 & 99.260 & 100.480 \\
\hline
\end{tabular}

UFRS

\begin{tabular}{lll}
\multicolumn{1}{c}{ PUL-44C } & & \\
\hline PXA.02C & CPX.12 & PXA.17 \\
$\begin{array}{ll}\text { sub-idio zonado. } \\
\text { CENTRO }\end{array}$ & $\begin{array}{l}\text { feno idio } \\
\text { pouco } \\
\text { fraturado }\end{array}$ & fragm de feno \\
\hline
\end{tabular}

\begin{tabular}{|c|c|}
\hline 53.208 & 51.01450 .964 \\
\hline 0.234 & 0.2280 .119 \\
\hline 2.758 & 0.8980 .527 \\
\hline 14.351 & 14.32731 .157 \\
\hline 0.000 & 0.0000 .000 \\
\hline 0.282 & 0.000 \\
\hline 0.241 & 0.4060 .767 \\
\hline 27.546 & 11.53915 .768 \\
\hline 1.012 & 21.2201 .106 \\
\hline 0.000 & 0.1850 .000 \\
\hline 0.015 & 0.0000 .000 \\
\hline 99.650 & 99.820 \\
\hline
\end{tabular}

Cátions para 6 oxigênios

\begin{tabular}{lrrr}
$\mathrm{Si}$ & 1.931 & 1.954 & 1.963 \\
$\mathrm{Al}^{\mathrm{IV}}$ & 0.069 & 0.045 & 0.032 \\
$\mathrm{Fe}^{3+}$ & 0.000 & 0.001 & 0.005 \\
& & & \\
$\mathrm{Al}^{\mathrm{VI}}$ & 0.026 & 0.000 & 0.000 \\
$\mathrm{Ti}$ & 0.008 & 0.005 & 0.004 \\
$\mathrm{Fe}^{3+}$ & 0.027 & 0.038 & 0.031 \\
$\mathrm{Fe}^{2+}$ & 0.000 & 0.042 & 0.024 \\
$\mathrm{Cr}$ & 0.000 & 0.000 & 0.000 \\
$\mathrm{Mg}$ & 0.939 & 0.915 & 0.941 \\
& & & \\
$\mathrm{Mg}$ & 0.426 & 0.000 & 0.000 \\
$\mathrm{Fe}$ & 0.513 & 0.927 & 0.935 \\
$\mathrm{Mn}$ & 0.010 & 0.021 & 0.020 \\
$\mathrm{Ca}$ & 0.051 & 0.051 & 0.043 \\
$\mathrm{Na}$ & 0.000 & 0.000 & 0.002 \\
$\mathrm{~K}$ & 0.001 & 0.001 & 0.000 \\
& & & \\
$\mathrm{WO}$ & 2.596 & 2.549 & 2.148 \\
$\mathrm{EN}$ & 69.445 & 45.877 & 47.036 \\
$\mathrm{FS}$ & 27.958 & 51.574 & 50.816 \\
$\mathrm{JD}$ & 0.000 & 0.000 & 0.000 \\
$\mathrm{AE}$ & 0.000 & 0.000 & 0.168 \\
$\mathrm{mg} \#$ & 0.717 & 0.476 & 0.486 \\
\hline & & &
\end{tabular}

\begin{tabular}{rrr}
1.913 & 1.946 & 1.978 \\
0.087 & 0.040 & 0.022 \\
0.000 & 0.014 & 0.000 \\
& & \\
0.030 & 0.000 & 0.002 \\
0.006 & 0.007 & 0.003 \\
0.036 & 0.055 & 0.013 \\
0.000 & 0.283 & 0.069 \\
0.008 & 0.000 & 0.000 \\
0.919 & 0.656 & 0.912 \\
& & \\
0.557 & 0.000 & 0.000 \\
0.396 & 0.106 & 0.929 \\
0.007 & 0.013 & 0.025 \\
0.039 & 0.867 & 0.046 \\
0.000 & 0.014 & 0.000 \\
0.001 & 0.000 & 0.000 \\
& & \\
1.995 & 43.502 & 2.306 \\
75.549 & 32.914 & 45.735 \\
22.456 & 23.584 & 51.960 \\
0.000 & 0.000 & 0.000 \\
0.000 & 1.402 & 0.000 \\
0.774 & 0.589 & 0.474 \\
\hline & &
\end{tabular}

$\mathrm{Fe}^{\alpha^{+}}$e $\mathrm{Fe}^{3+}$ calculados por estequeometria; $\mathrm{Wo}=\mathrm{Ca}$; $\mathrm{En}=\mathrm{Mg} ; \mathrm{Fs}=\mathrm{Fe}^{2+}+\mathrm{Fe}^{3+}+\mathrm{Mn}$ $\mathrm{mg} \#=100 *\left[\mathrm{Mg} /\left(\mathrm{Mg}+\mathrm{Fe}^{<+}+\mathrm{Fe}^{3+}\right)\right]$

c: centro; i: zona intermediária; b: borda

feno: fenocristal; mfeno:microfenocristal; idio: idiomórfico; sub-idio: sub-idiomórfico; xeno: xenomórfico; incl: inclusão; frag: fragmentado; cc: concentração; pq: pequeno; gde: grande plag: plagioclásio; bio: biotita 
ANEXO V - Tabelas 3.

Análise química dos piroxênios

\begin{tabular}{|c|c|c|c|c|c|c|c|}
\hline análise & PXA.20 & PXA.21 & PXA.22 & CPX.23 & PXN.08 & PXN.30 & СРХ.29 \\
\hline descrição & $\begin{array}{l}\text { xeno repleto } \\
\text { de incl de } \\
\text { opacos e bt }\end{array}$ & $\begin{array}{l}\text { sub-idio. } \\
\text { repleto de incl }\end{array}$ & $\begin{array}{l}\text { mfeno. sub- } \\
\text { idio associado } \\
\text { a cc de } \\
\text { maficos }\end{array}$ & feno idio & microc idio & $\begin{array}{l}\text { frag de feno } \\
\text { idio }\end{array}$ & $\begin{array}{l}\text { microcristal sub-idio } \\
\text { incl de plag frat }\end{array}$ \\
\hline
\end{tabular}

\begin{tabular}{|c|c|c|c|c|c|c|c|}
\hline $\mathrm{SiO}_{2}$ & 51.877 & 52.372 & 52.211 & 51.170 & 50.365 & 50.157 & 51.231 \\
\hline $\mathrm{TiO}_{2}$ & 0.238 & 0.149 & 0.356 & 0.049 & 0.056 & 0.070 & 0.113 \\
\hline $\mathrm{Al}_{2} \mathrm{O}_{3}$ & 0.542 & 0.613 & 3.443 & 0.695 & 0.414 & 0.448 & 0.869 \\
\hline $\mathrm{FeO}$ & 25.283 & 25.949 & 18.186 & 14.362 & 30.984 & 31.902 & 14.454 \\
\hline $\mathrm{Fe}_{2} \mathrm{O}_{3}$ & 0.000 & 0.000 & 0.000 & 0.000 & 0.000 & 0.000 & 0.000 \\
\hline $\mathrm{Cr}_{2} \mathrm{O}_{3}$ & 0.000 & 0.013 & 0.043 & 0.010 & 0.000 & 0.000 & 0.000 \\
\hline MnO & 0.485 & 0.478 & 0.315 & 0.450 & 0.739 & 0.780 & 0.400 \\
\hline $\mathrm{MgO}$ & 19.605 & 19.003 & 24.256 & 11.411 & 15.563 & 15.183 & 11.495 \\
\hline $\mathrm{CaO}$ & 1.788 & 1.721 & 1.782 & 21.288 & 1.153 & 1.081 & 20.393 \\
\hline $\mathrm{Na}_{2} \mathrm{O}$ & 0.012 & 0.018 & 0.018 & 0.213 & 0.023 & 0.018 & 0.261 \\
\hline $\mathrm{K}_{2} \mathrm{O}$ & 0.013 & 0.023 & 0.000 & 0.012 & 0.003 & 0.021 & 0.000 \\
\hline Total & 99.840 & 100.340 & 100.610 & 99.660 & 99.300 & 99.660 & 99.220 \\
\hline
\end{tabular}

\begin{tabular}{|c|c|c|c|c|c|c|c|}
\hline $\mathrm{Si}$ & 1.968 & 1.985 & 1.896 & 1.955 & 1.977 & 1.968 & 1.966 \\
\hline $\mathrm{Al}^{\mathrm{IV}}$ & 0.024 & 0.015 & 0.104 & 0.031 & 0.019 & 0.021 & 0.034 \\
\hline $\mathrm{Fe}^{3+}$ & 0.008 & 0.000 & 0.000 & 0.013 & 0.004 & 0.011 & 0.000 \\
\hline $\mathrm{Al}^{\mathrm{VI}}$ & 0.000 & 0.012 & 0.043 & 0.000 & 0.000 & 0.000 & 0.005 \\
\hline $\mathrm{Ti}$ & 0.007 & 0.004 & 0.010 & 0.001 & 0.002 & 0.002 & 0.003 \\
\hline $\mathrm{Fe}^{3+}$ & 0.020 & 0.000 & 0.041 & 0.058 & 0.022 & 0.030 & 0.042 \\
\hline $\mathrm{Fe}^{2+}$ & 0.000 & 0.000 & 0.000 & 0.290 & 0.066 & 0.080 & 0.292 \\
\hline $\mathrm{Cr}$ & 0.000 & 0.000 & 0.001 & 0.000 & 0.000 & 0.000 & 0.000 \\
\hline $\mathrm{Mg}$ & 0.974 & 0.983 & 0.905 & 0.650 & 0.911 & 0.888 & 0.657 \\
\hline $\mathrm{Mg}$ & 0.135 & 0.090 & 0.408 & 0.000 & 0.000 & 0.000 & 0.000 \\
\hline $\mathrm{Fe}^{2+}$ & 0.775 & 0.822 & 0.511 & 0.097 & 0.925 & 0.926 & 0.129 \\
\hline $\mathrm{Mn}$ & 0.016 & 0.015 & 0.010 & 0.015 & 0.025 & 0.026 & 0.013 \\
\hline $\mathrm{Ca}$ & 0.073 & 0.070 & 0.069 & 0.872 & 0.048 & 0.045 & 0.838 \\
\hline $\mathrm{Na}$ & 0.001 & 0.001 & 0.001 & 0.016 & 0.002 & 0.001 & 0.019 \\
\hline K & 0.001 & 0.001 & 0.000 & 0.001 & 0.000 & 0.001 & 0.000 \\
\hline WO & 3.635 & 3.527 & 3.566 & 43.685 & 2.423 & 2.265 & 42.498 \\
\hline EN & 55.461 & 54.188 & 67.532 & 32.581 & 45.515 & 44.266 & 33.331 \\
\hline FS & 40.903 & 42.285 & 28.902 & 23.734 & 52.061 & 53.469 & 24.170 \\
\hline JD & 0.000 & 0.133 & 0.068 & 0.000 & 0.000 & 0.000 & 0.201 \\
\hline$A E$ & 0.089 & 0.000 & 0.065 & 1.614 & 0.177 & 0.139 & 1.771 \\
\hline $\mathrm{mg \#}$ & 0.580 & 0.566 & 0.704 & 0.587 & 0.473 & 0.459 & 0.587 \\
\hline
\end{tabular}

$\mathrm{Fe}^{\alpha^{+}}$e $\mathrm{Fe}^{\mathrm{s}^{+}}$calculados por estequeometria; $\mathrm{Wo}=\mathrm{Ca} ; \mathrm{En}=\mathrm{Mg} ; \mathrm{Fs}=\mathrm{Fe}^{2+}+\mathrm{Fe}^{3+}+\mathrm{Mn}$ $\mathrm{mg} \#=100 *\left[\mathrm{Mg} /\left(\mathrm{Mg}+\mathrm{Fe}^{2+}+\mathrm{Fe}^{3+}\right)\right]$

c: centro; i: zona intermediária; b: borda

feno: fenocristal; mfeno:microfenocristal; idio: idiomórfico; sub-idio: sub-idiomórfico; xeno: xenomórfico; incl: inclusão; frag: fragmentado; cc: concentração; pq: pequeno; gde: grande

plag: plagioclásio; bio: biotita 
ANEXO V - Tabelas 3.

Análise química dos piroxênios

UFRS

Amostra: PUL-44D

\begin{tabular}{|c|c|c|c|c|c|c|c|c|}
\hline análise & PXA.02 & PXA.05 & PXA.08 & CPX.14 & CPX.16 & CPX.141 & CPX.20 & PXA.81 \\
\hline
\end{tabular}

\begin{tabular}{lrrrrrrrr}
$\mathrm{SiO}_{2}$ & 51.212 & 50.203 & 49.787 & 51.392 & 51.172 & 51.955 & 51.639 & 50.031 \\
$\mathrm{TiO}_{2}$ & 0.078 & 0.074 & 0.179 & 0.180 & 0.136 & 0.168 & 0.059 & 0.079 \\
$\mathrm{Al}_{2} \mathrm{O}_{3}$ & 0.442 & 0.063 & 0.850 & 0.987 & 0.894 & 0.731 & 0.706 & 0.602 \\
$\mathrm{FeO}$ & 30.648 & 30.572 & 30.233 & 13.464 & 14.206 & 13.179 & 13.779 & 29.688 \\
$\mathrm{Fe}_{2} \mathrm{O}_{3}$ & 0.000 & 0.000 & 0.000 & 0.000 & 0.000 & 0.000 & 0.000 & 0.000 \\
$\mathrm{Cr}_{2} \mathrm{O}_{3}$ & 0.000 & 0.008 & 0.016 & 0.000 & 0.007 & 0.000 & 0.000 & 0.000 \\
$\mathrm{MnO}$ & 0.723 & 0.715 & 0.876 & 0.345 & 0.528 & 0.282 & 0.395 & 0.852 \\
$\mathrm{MgO}$ & 15.980 & 15.883 & 15.213 & 12.080 & 11.266 & 12.041 & 11.532 & 15.744 \\
$\mathrm{CaO}$ & 1.139 & 0.794 & 1.113 & 21.310 & 20.990 & 21.176 & 20.413 & 0.780 \\
$\mathrm{Na} 2 \mathrm{O}$ & 0.022 & 0.015 & 0.000 & 0.207 & 0.238 & 0.189 & 0.231 & 0.031 \\
$\mathrm{~K}_{2} \mathrm{O}$ & 0.000 & 0.014 & 0.023 & 0.007 & 0.000 & 0.015 & 0.014 & 0.009 \\
$\mathrm{Total}$ & 100.240 & 98.340 & 98.290 & 99.970 & 99.440 & 99.740 & 98.770 & 97.820 \\
\hline
\end{tabular}

Cátions para 6 oxigênios

\begin{tabular}{|c|c|c|c|c|c|c|c|c|}
\hline $\mathrm{Si}$ & 1.987 & 1.987 & 1.974 & 1.949 & 1.960 & 1.975 & 1.988 & 1.987 \\
\hline $\mathrm{Al}^{\mathrm{IV}}$ & 0.013 & 0.003 & 0.026 & 0.044 & 0.040 & 0.025 & 0.012 & 0.013 \\
\hline $\mathrm{Fe}^{3+}$ & 0.000 & 0.011 & 0.000 & 0.007 & 0.000 & 0.000 & 0.000 & 0.000 \\
\hline $\mathrm{Al}^{\mathrm{VI}}$ & 0.007 & 0.000 & 0.014 & 0.000 & 0.001 & 0.008 & 0.020 & 0.015 \\
\hline $\mathrm{Ti}$ & 0.002 & 0.002 & 0.005 & 0.005 & 0.004 & 0.005 & 0.002 & 0.002 \\
\hline $\mathrm{Fe}^{3+}$ & 0.004 & 0.011 & 0.001 & 0.057 & 0.048 & 0.022 & 0.006 & 0.000 \\
\hline $\mathrm{Fe}^{2+}$ & 0.063 & 0.050 & 0.079 & 0.256 & 0.303 & 0.283 & 0.310 & 0.051 \\
\hline $\mathrm{Cr}$ & 0.000 & 0.000 & 0.001 & 0.000 & 0.000 & 0.000 & 0.000 & 0.000 \\
\hline $\mathrm{Mg}$ & 0.924 & 0.937 & 0.899 & 0.683 & 0.643 & 0.682 & 0.662 & 0.932 \\
\hline $\mathrm{Mg}$ & 0.000 & 0.000 & 0.000 & 0.000 & 0.000 & 0.000 & 0.000 & 0.000 \\
\hline $\mathrm{Fe}^{2+}$ & 0.927 & 0.941 & 0.922 & 0.108 & 0.104 & 0.114 & 0.127 & 0.935 \\
\hline $\mathrm{Mn}$ & 0.024 & 0.024 & 0.029 & 0.011 & 0.017 & 0.009 & 0.013 & 0.029 \\
\hline $\mathrm{Ca}$ & 0.047 & 0.034 & 0.047 & 0.866 & 0.862 & 0.862 & 0.842 & 0.033 \\
\hline $\mathrm{Na}$ & 0.002 & 0.001 & 0.000 & 0.015 & 0.018 & 0.014 & 0.017 & 0.002 \\
\hline $\mathrm{K}$ & 0.000 & 0.001 & 0.001 & 0.000 & 0.000 & 0.001 & 0.001 & 0.000 \\
\hline wo & 2.379 & 1.678 & 2.390 & 43.579 & 43.574 & 43.716 & 42.951 & 1.676 \\
\hline EN & 46.450 & 46.701 & 45.451 & 34.372 & 32.541 & 34.587 & 33.762 & 47.077 \\
\hline FS & 51.170 & 51.622 & 52.159 & 22.049 & 23.885 & 21.697 & 23.287 & 51.247 \\
\hline $\mathrm{JD}$ & 0.106 & 0.000 & 0.000 & 0.000 & 0.031 & 0.361 & 1.314 & 0.241 \\
\hline $\mathrm{AE}$ & 0.061 & 0.116 & 0.000 & 1.558 & 1.769 & 1.047 & 0.420 & 0.000 \\
\hline $\mathrm{mg} \#$ & 0.482 & 0.481 & 0.473 & 0.615 & 0.586 & 0.619 & 0.599 & 0.486 \\
\hline
\end{tabular}

$\mathrm{Fe}^{2+}$ e $\mathrm{Fe}^{3+}$ calculados por estequeometria; $\mathrm{Wo}=\mathrm{Ca}$; $\mathrm{En}=\mathrm{Mg} ; \mathrm{Fs}=\mathrm{Fe}^{2+}+\mathrm{Fe}^{3+}+\mathrm{Mn}$ $\mathrm{mg} \#=100 *\left[\mathrm{Mg} /\left(\mathrm{Mg}+\mathrm{Fe}^{2+}+\mathrm{Fe}^{3+}\right)\right]$

c: centro; i: zona intermediária; b: borda

feno: fenocristal; mfeno:microfenocristal; idio: idiomórfico; sub-idio: sub-idiomórfico; xeno: xenomórfico; incl: inclusão; frag: fragmentado; frat: fraturado cc: concentração; pq: pequeno; gde: grande plag: plagioclásio; bio: biotita 
ANEXO V - Tabelas 3.

Análise química dos piroxênios

FLP

Amostra: PUL-38E

\begin{tabular}{|c|c|c|c|c|c|c|c|c|}
\hline análise & PXL.1 & PXL.2 & PXL.13 & PXL.4 & PXL.15 & PXL.16 & PXL.21.1 & PXL.3 \\
\hline descrição & $\begin{array}{l}\text { assoc a gde } \\
\text { aglomerado } \\
\text { de maficos ox }\end{array}$ & $\begin{array}{l}\text { assoc a gde } \\
\text { aglomerado } \\
\text { de maficos ox }\end{array}$ & $\begin{array}{l}\text { cristal xeno na } \\
\text { borda de feno } \\
\text { bio }\end{array}$ & $\begin{array}{l}\text { mfeno idio na } \\
\text { borda de } \\
\text { aglom mafico } \\
\text { ox }\end{array}$ & $\begin{array}{l}\text { px dentro de } \\
\text { bt c/ ox } \\
\text { avançada }\end{array}$ & $\begin{array}{l}\text { px dentro de } \\
\text { bt c/ ox } \\
\text { avançada }\end{array}$ & $\begin{array}{l}\text { resquicio } \\
\text { assoc a borda } \\
\text { de aglom } \\
\text { mafico }\end{array}$ & $\begin{array}{l}\text { assoc a } \\
\text { aglomer. } \\
\text { mafico }\end{array}$ \\
\hline
\end{tabular}

\begin{tabular}{|c|c|c|c|c|c|c|c|c|}
\hline $\mathrm{SiO}_{2}$ & 52.687 & 51.866 & 51.648 & 51.296 & 51.561 & 51.329 & 51.620 & 52.386 \\
\hline $\mathrm{TiO}_{2}$ & 0.069 & 0.093 & 0.054 & 0.075 & 0.211 & 0.142 & 0.142 & 0.108 \\
\hline $\mathrm{Al}_{2} \mathrm{O}_{3}$ & 0.592 & 0.780 & 0.827 & 0.252 & 0.746 & 0.852 & 0.828 & 0.750 \\
\hline $\mathrm{FeO}$ & 13.180 & 13.923 & 14.661 & 28.710 & 14.094 & 14.551 & 13.916 & 12.730 \\
\hline $\mathrm{Fe}_{2} \mathrm{O}_{3}$ & 0.000 & 0.000 & 0.000 & 0.000 & 0.000 & 0.000 & 0.000 & 0.000 \\
\hline $\mathrm{Cr}_{2} \mathrm{O}_{3}$ & 0.000 & 0.028 & 0.000 & 0.029 & 0.028 & 0.042 & 0.028 & 0.000 \\
\hline $\mathrm{MnO}$ & 0.725 & 0.783 & 0.892 & 1.806 & 0.724 & 0.821 & 0.675 & 0.663 \\
\hline $\mathrm{MgO}$ & 12.109 & 11.848 & 10.835 & 15.721 & 11.294 & 11.143 & 11.167 & 12.144 \\
\hline $\mathrm{CaO}$ & 20.606 & 19.969 & 19.963 & 1.136 & 20.056 & 19.820 & 20.127 & 20.537 \\
\hline $\mathrm{Na}_{2} \mathrm{O}$ & 0.159 & 0.223 & 0.300 & 0.005 & 0.285 & 0.265 & 0.279 & 0.278 \\
\hline $\mathrm{K}_{2} \mathrm{O}$ & 0.000 & 0.000 & 0.003 & 0.000 & 0.005 & 0.006 & 0.009 & 0.000 \\
\hline Total & 100.130 & 99.510 & 99.180 & 99.030 & 99.000 & 98.970 & 98.790 & 99.600 \\
\hline
\end{tabular}

Cátions para 6 oxigênios

\begin{tabular}{|c|c|c|c|c|c|c|c|c|}
\hline Si & 1.997 & 1.982 & 1.990 & 2.014 & 1.985 & 1.980 & 1.991 & 1.992 \\
\hline $\mathrm{Al}^{\mathrm{IV}}$ & 0.003 & 0.018 & 0.010 & 0.000 & 0.015 & 0.020 & 0.009 & 0.008 \\
\hline $\mathrm{Fe}^{3+}$ & 0.000 & 0.000 & 0.000 & 0.000 & 0.000 & 0.000 & 0.000 & 0.000 \\
\hline $\mathrm{Al}^{\mathrm{VI}}$ & 0.024 & 0.017 & 0.028 & 0.012 & 0.019 & 0.018 & 0.029 & 0.025 \\
\hline $\mathrm{Ti}$ & 0.002 & 0.003 & 0.002 & 0.002 & 0.006 & 0.004 & 0.004 & 0.003 \\
\hline $\mathrm{Fe}^{2+}$ & 0.290 & 0.293 & 0.347 & 0.065 & 0.321 & 0.323 & 0.324 & 0.283 \\
\hline $\mathrm{Cr}$ & 0.000 & 0.001 & 0.000 & 0.001 & 0.001 & 0.001 & 0.001 & 0.000 \\
\hline $\mathrm{Mg}$ & 0.684 & 0.675 & 0.622 & 0.920 & 0.648 & 0.641 & 0.642 & 0.688 \\
\hline $\mathrm{Mg}$ & 0.000 & 0.000 & 0.000 & 0.000 & 0.000 & 0.000 & 0.000 & 0.000 \\
\hline $\mathrm{Ca}$ & 0.837 & 0.818 & 0.824 & 0.048 & 0.827 & 0.819 & 0.832 & 0.837 \\
\hline $\mathrm{Na}$ & 0.012 & 0.017 & 0.022 & 0.000 & 0.021 & 0.020 & 0.021 & 0.020 \\
\hline $\mathrm{K}$ & 0.000 & 0.000 & 0.000 & 0.000 & 0.000 & 0.000 & 0.000 & 0.000 \\
\hline WO & 42.649 & 41.653 & 42.306 & 2.425 & 42.362 & 41.875 & 42.768 & 42.880 \\
\hline EN & 34.872 & 34.387 & 31.949 & 46.692 & 33.192 & 32.757 & 33.016 & 35.280 \\
\hline $\mathrm{FS}$ & 22.479 & 23.960 & 25.746 & 50.883 & 24.445 & 25.368 & 24.215 & 21.841 \\
\hline JD & 1.177 & 1.009 & 2.140 & 0.039 & 1.713 & 1.205 & 2.101 & 2.058 \\
\hline$A E$ & 0.000 & 0.656 & 0.111 & 0.000 & 0.425 & 0.793 & 0.000 & 0.000 \\
\hline
\end{tabular}

$\mathrm{Fe}^{\alpha^{+}}$e $\mathrm{Fe}^{\mathrm{s+}}$ calculados por estequeometria; $\mathrm{Wo}=\mathrm{Ca} ; \mathrm{En}=\mathrm{Mg} ; \mathrm{Fs}=\mathrm{Fe}^{\mathrm{Lt}}+\mathrm{Fe}^{\mathrm{s+}}+\mathrm{Mn}$ $\mathrm{mg} \#=100 *\left[\mathrm{Mg} /\left(\mathrm{Mg}+\mathrm{Fe}^{2+}+\mathrm{Fe}^{3+}\right)\right]$

c: centro; i: zona intermediária; b: borda

feno: fenocristal; mfeno:microfenocristal; idio: idiomórfico; sub-idio: sub-idiomórfico; xeno: xenomórfico;

incl: inclusão; frag: fragmentado; cc: concentração; pq: pequeno; gde: grande

plag: plagioclásio; bio: biotita 
ANEXO V - Tabelas 3.

Análise química dos piroxênios

FLP

\begin{tabular}{lll} 
Amostra: PUL-38E & \\
\hline análise & PXL.23 & PXL.24 \\
descrição & $\begin{array}{l}\text { assoc a gde } \\
\text { aglomerado } \\
\text { de maficos ox }\end{array}$ & $\begin{array}{l}\text { assoc a gde merado } \\
\text { de maficos ox }\end{array}$ \\
\hline
\end{tabular}

\begin{tabular}{lrr}
\hline & & \\
$\mathrm{SiO}_{2}$ & 51.571 & 51.657 \\
$\mathrm{TiO}_{2}$ & 0.047 & 0.061 \\
$\mathrm{Al}_{2} \mathrm{O}_{3}$ & 0.231 & 0.440 \\
$\mathrm{FeO}$ & 29.125 & 28.346 \\
$\mathrm{Fe}_{2} \mathrm{O}_{3}$ & 0.000 & 0.000 \\
$\mathrm{Cr}_{2} \mathrm{O}_{3}$ & 0.020 & 0.050 \\
$\mathrm{MnO}$ & 1.712 & 1.578 \\
$\mathrm{MgO}$ & 15.682 & 16.287 \\
$\mathrm{CaO}$ & 1.149 & 1.111 \\
$\mathrm{Na}$ & 0.008 & 0.000 \\
$\mathrm{~K}$ & 0.036 & 0.000 \\
$\mathrm{Total}$ & 99.580 & 99.530 \\
\hline
\end{tabular}

CIP

\begin{tabular}{llll}
$\mathrm{H}-03$ & & & \\
\hline HPX3 & HPX23 & HPX16 & HPX06 \\
$\begin{array}{l}\text { mfeno frag e } \\
\text { bordas oxid }\end{array}$ & $\begin{array}{l}\text { xeno c/ incl de } \\
\text { oxidos }\end{array}$ & mfeno xeno & $\begin{array}{l}\text { cristal idio c/ } \\
\text { borda intercresc } \\
\text { c/ feno de bio }\end{array}$ \\
\hline
\end{tabular}

$\longrightarrow$

\begin{tabular}{rrrr}
50.485 & 51.631 & 50.878 & 49.781 \\
0.260 & 0.289 & 0.200 & 0.102 \\
2.031 & 1.879 & 0.684 & 0.529 \\
24.773 & 23.655 & 29.937 & 31.171 \\
0.000 & 0.000 & 0.000 & 0.000 \\
0.000 & 0.000 & 0.001 & 0.000 \\
0.425 & 0.441 & 0.620 & 1.400 \\
19.909 & 20.745 & 16.609 & 15.144 \\
1.255 & 1.229 & 0.717 & 0.977 \\
0.041 & 0.036 & 0.000 & 0.008 \\
0.020 & 0.000 & 0.024 & 0.030 \\
99.200 & 99.910 & 99.670 & 99.140 \\
\hline
\end{tabular}

Cátions para 6 oxigênios

\begin{tabular}{lrr}
$\mathrm{Si}$ & 2.015 & 2.011 \\
$\mathrm{Al}^{\mathrm{IV}}$ & 0.000 & 0.000 \\
$\mathrm{Fe}^{3+}$ & 0.000 & 0.000 \\
& & \\
$\mathrm{Al}^{\mathrm{Vl}}$ & 0.011 & 0.020 \\
$\mathrm{Ti}$ & 0.001 & 0.002 \\
$\mathrm{Fe}^{3+}$ & 0.000 & 0.000 \\
$\mathrm{Fe}^{2+}$ & 0.074 & 0.032 \\
$\mathrm{Cr}$ & 0.001 & 0.002 \\
$\mathrm{Mg}$ & 0.913 & 0.945 \\
& & \\
$\mathrm{Mg}$ & 0.000 & 0.000 \\
$\mathrm{Fe}$ & 0.878 & 0.891 \\
$\mathrm{Mn}$ & 0.057 & 0.052 \\
$\mathrm{Ca}$ & 0.048 & 0.046 \\
$\mathrm{Na}$ & 0.001 & 0.000 \\
$\mathrm{~K}$ & 0.002 & 0.000 \\
& & \\
$\mathrm{WO}$ & 2.442 & 2.357 \\
$\mathrm{EN}$ & 46.370 & 48.067 \\
$\mathrm{FS}$ & 51.188 & 49.576 \\
$\mathrm{JD}$ & 0.061 & 0.000 \\
$\mathrm{AE}$ & 0.000 & 0.000 \\
$\mathrm{mg} \#$ & 0.490 & 0.506 \\
\hline & &
\end{tabular}

\begin{tabular}{rrrr}
1.918 & 1.939 & 1.977 & 1.964 \\
0.082 & 0.061 & 0.023 & 0.025 \\
0.000 & 0.000 & 0.000 & 0.012 \\
& & & \\
0.009 & 0.022 & 0.008 & 0.000 \\
0.007 & 0.008 & 0.006 & 0.003 \\
0.062 & 0.026 & 0.005 & 0.032 \\
0.000 & 0.000 & 0.019 & 0.074 \\
0.000 & 0.000 & 0.000 & 0.000 \\
0.922 & 0.944 & 0.962 & 0.890 \\
& & & \\
0.206 & 0.217 & 0.000 & 0.000 \\
0.725 & 0.717 & 0.949 & 0.910 \\
0.014 & 0.014 & 0.020 & 0.047 \\
0.051 & 0.049 & 0.030 & 0.041 \\
0.003 & 0.003 & 0.000 & 0.001 \\
0.001 & 0.000 & 0.001 & 0.002 \\
& & & \\
2.581 & 2.513 & 1.504 & 2.057 \\
56.965 & 59.020 & 48.464 & 44.374 \\
40.454 & 38.467 & 50.032 & 53.568 \\
0.040 & 0.123 & 0.000 & 0.000 \\
0.274 & 0.146 & 0.000 & 0.062 \\
0.589 & 0.610 & 0.497 & 0.464 \\
\hline & & &
\end{tabular}

$\mathrm{Fe}^{2+}$ e $\mathrm{Fe}^{3^{+}}$calculados por estequeometria; $\mathrm{Wo}=\mathrm{Ca} ; \mathrm{En}=\mathrm{Mg} ; \mathrm{Fs}=\mathrm{Fe}^{2+}+\mathrm{Fe}^{3+}+\mathrm{Mn}$ $\mathrm{mg} \#=100 *\left[\mathrm{Mg} /\left(\mathrm{Mg}+\mathrm{Fe}^{<+}+\mathrm{Fe}^{3+}\right)\right]$

c: centro; i: zona intermediária; b: borda

feno: fenocristal; mfeno:microfenocristal; idio: idiomórfico; sub-idio: sub-idiomórfico; xeno: xenomórfico; incl: inclusão; frag: fragmentado; cc: concentração; pq: pequeno; gde: grande plag: plagioclásio; bio: biotita 
ANEXO V - Tabelas 3.

Análise química dos piroxênios

CIP

Amostra: PUL-H-03

\begin{tabular}{|c|c|c|c|}
\hline análise & $\begin{array}{l}\text { HPX7.2 } \\
\text { sub-idio c/ borda } \\
\text { de alteração }\end{array}$ & $\begin{array}{l}\text { HPX29 } \\
\text { feno xeno } \\
\text { intercresc c/ plag }\end{array}$ & $\begin{array}{l}\text { HPX.19.1 } \\
\text { sub-idio c/ } \\
\text { bordas ox e } \\
\text { algumas } \\
\text { inclusoes }\end{array}$ \\
\hline $\mathrm{SiO}_{2}$ & 50.423 & 50.212 & 50.641 \\
\hline $\mathrm{TiO}_{2}$ & 0.088 & 0.284 & 0.103 \\
\hline $\mathrm{Al}_{2} \mathrm{O}_{3}$ & 0.589 & 2.822 & 0.572 \\
\hline $\mathrm{FeO}$ & 31.070 & 24.931 & 30.456 \\
\hline $\mathrm{Fe}_{2} \mathrm{O}_{3}$ & 0.000 & 0.000 & 0.000 \\
\hline $\mathrm{Cr}_{2} \mathrm{O}_{3}$ & 0.000 & 0.036 & 0.000 \\
\hline $\mathrm{MnO}$ & 1.390 & 0.336 & 0.875 \\
\hline $\mathrm{MgO}$ & 14.825 & 19.667 & 16.220 \\
\hline $\mathrm{CaO}$ & 0.966 & 1.098 & 0.915 \\
\hline $\mathrm{Na}_{2} \mathrm{O}$ & 0.048 & 0.054 & 0.000 \\
\hline $\mathrm{K}_{2} \mathrm{O}$ & 0.009 & 0.000 & 0.000 \\
\hline Total & 99.410 & 99.440 & 99.780 \\
\hline
\end{tabular}

Cátions para 6 oxigênios

\begin{tabular}{|c|c|c|c|}
\hline $\mathrm{Si}$ & 1.985 & 1.904 & 1.971 \\
\hline $\mathrm{Al}^{\mathrm{IV}}$ & 0.015 & 0.096 & 0.026 \\
\hline $\mathrm{Fe}^{3+}$ & 0.000 & 0.000 & 0.003 \\
\hline $\mathrm{Al}^{\mathrm{VI}}$ & 0.013 & 0.030 & 0.000 \\
\hline $\mathrm{Ti}$ & 0.003 & 0.008 & 0.003 \\
\hline $\mathrm{Fe}^{3+}$ & 0.001 & 0.053 & 0.023 \\
\hline $\mathrm{Fe}^{2+}$ & 0.114 & 0.000 & 0.033 \\
\hline $\mathrm{Cr}$ & 0.000 & 0.001 & 0.000 \\
\hline $\mathrm{Mg}$ & 0.870 & 0.908 & 0.941 \\
\hline $\mathrm{Mg}$ & 0.000 & 0.203 & 0.000 \\
\hline $\mathrm{Fe}^{2+}$ & 0.909 & 0.737 & 0.933 \\
\hline $\mathrm{Mn}$ & 0.046 & 0.011 & 0.029 \\
\hline $\mathrm{Ca}$ & 0.041 & 0.045 & 0.038 \\
\hline $\mathrm{Na}$ & 0.004 & 0.004 & 0.000 \\
\hline K & 0.000 & 0.000 & 0.000 \\
\hline WO & 2.058 & 2.279 & 1.908 \\
\hline EN & 43.941 & 56.787 & 47.069 \\
\hline FS & 54.002 & 40.934 & 51.023 \\
\hline JD & 0.353 & 0.148 & 0.000 \\
\hline$A E$ & 0.016 & 0.267 & 0.000 \\
\hline $\mathrm{mg} \#$ & 0.459 & 0.584 & 0.487 \\
\hline
\end{tabular}

$\mathrm{Fe}^{\alpha^{+}}$e $\mathrm{Fe}^{\mathrm{s}^{+}}$calculados por estequeometria; $\mathrm{Wo}=\mathrm{Ca}$; $\mathrm{En}=\mathrm{Mg} ; \mathrm{Fs}=\mathrm{Fe}^{\mathrm{L}^{+}}+\mathrm{Fe}^{\mathrm{s}^{+}}+\mathrm{Mn}$ $\mathrm{mg} \#=100 *\left[\mathrm{Mg} /\left(\mathrm{Mg}+\mathrm{Fe}^{<+}+\mathrm{Fe}^{3+}\right)\right]$

c: centro; i: zona intermediária; b: borda

feno: fenocristal; mfeno:microfenocristal; idio: idiomórfico; sub-idio: sub-idiomórfico; xeno: xenomórfico; incl: inclusão; frag: fragmentado; cc: concentração; pq: pequeno; gde: grande plag: plagioclásio; bio: biotita 
ANEXO V - Tabelas 4

\section{Análise química dos anfibólios}

UFRS

Amostra: PUL-44B

\begin{tabular}{|c|c|c|c|c|c|c|c|c|}
\hline análise & $\begin{array}{l}\text { 20c } \\
\text { mfeno idio com } \\
\text { bordas corr }\end{array}$ & anf11c & $\begin{array}{l}\text { anf12c } \\
\text { mfeno idio } \\
\text { pouco frat }\end{array}$ & feno idio. C & idem; i & idem; $b$ & $\begin{array}{l}13 c \\
\text { mfeno idio } \\
\text { quebrado }\end{array}$ & $\begin{array}{l}\quad 20 \mathrm{c} \\
\text { mfeno idio } \\
\text { com bordas } \\
\text { corr }\end{array}$ \\
\hline $\mathrm{SiO}_{2}$ & 44.175 & 44.186 & 44.032 & 44.554 & 43.839 & 44.070 & 44.512 & 44.873 \\
\hline $\mathrm{TiO}_{2}$ & 1.831 & 1.855 & 1.842 & 1.626 & 1.737 & 1.726 & 1.557 & 1.537 \\
\hline $\mathrm{Al}_{2} \mathrm{O}_{3}$ & 9.067 & 9.475 & 9.393 & 9.318 & 9.711 & 9.683 & 9.336 & 8.940 \\
\hline $\mathrm{FeO}$ & 18.496 & 19.506 & 19.524 & 20.015 & 19.971 & 18.616 & 20.217 & 18.889 \\
\hline $\mathrm{Cr}_{2} \mathrm{O}_{3}$ & 0.000 & 0.000 & 0.000 & 0.000 & 0.000 & 0.000 & 0.000 & 0.000 \\
\hline $\mathrm{MnO}$ & 0.178 & 0.161 & 0.181 & 0.192 & 0.216 & 0.161 & 0.186 & 0.188 \\
\hline $\mathrm{MgO}$ & 10.409 & 10.171 & 10.005 & 10.118 & 9.788 & 9.970 & 9.949 & 10.558 \\
\hline $\mathrm{CaO}$ & 11.258 & 9.914 & 9.739 & 9.670 & 9.589 & 10.428 & 9.973 & 10.371 \\
\hline $\mathrm{Na}_{2} \mathrm{O}$ & 1.337 & 1.399 & 1.372 & 1.458 & 1.414 & 1.324 & 1.458 & 1.251 \\
\hline $\mathrm{K}_{2} \mathrm{O}$ & 0.924 & 1.135 & 1.046 & 1.063 & 1.096 & 1.285 & 1.114 & 1.104 \\
\hline$F$ & 0.000 & 0.444 & 0.112 & 0.259 & 0.474 & 0.124 & 0.290 & 0.110 \\
\hline $\mathrm{Cl}$ & 0.000 & 0.203 & 0.216 & 0.146 & 0.216 & 0.272 & 0.202 & 0.200 \\
\hline Total & 97.680 & 98.450 & 97.460 & 98.420 & 98.050 & 97.660 & 98.790 & 98.020 \\
\hline \multicolumn{9}{|c|}{ Cátions para 23 oxigênios } \\
\hline Si & 6.573 & 6.502 & 6.514 & 6.527 & 6.472 & 6.560 & 6.533 & 6.610 \\
\hline Al & 1.427 & 1.498 & 1.486 & 1.473 & 1.528 & 1.440 & 1.467 & 1.390 \\
\hline $\mathrm{Fe}^{3+}$ & 0.000 & 0.000 & 0.000 & 0.000 & 0.000 & 0.000 & 0.000 & 0.000 \\
\hline $\mathrm{Ti}$ & 0.000 & 0.000 & 0.000 & 0.000 & 0.000 & 0.000 & 0.000 & 0.000 \\
\hline $\mathrm{Al}$ & 0.162 & 0.143 & 0.150 & 0.135 & 0.160 & 0.257 & 0.147 & 0.161 \\
\hline $\mathrm{Cr}$ & 0.000 & 0.000 & 0.000 & 0.000 & 0.000 & 0.000 & 0.000 & 0.000 \\
\hline $\mathrm{Fe}^{3+}$ & 0.704 & 1.206 & 1.247 & 1.331 & 1.337 & 0.845 & 1.217 & 1.050 \\
\hline $\mathrm{Ti}$ & 0.205 & 0.205 & 0.205 & 0.179 & 0.193 & 0.193 & 0.172 & 0.170 \\
\hline Mg & 2.309 & 2.231 & 2.206 & 2.210 & 2.154 & 2.212 & 2.177 & 2.318 \\
\hline $\mathrm{Fe}^{2+}$ & 1.598 & 1.194 & 1.168 & 1.121 & 1.128 & 1.472 & 1.265 & 1.277 \\
\hline $\mathrm{Mn}$ & 0.022 & 0.020 & 0.023 & 0.024 & 0.027 & 0.020 & 0.023 & 0.023 \\
\hline $\mathrm{Ca}$ & 0.000 & 0.000 & 0.000 & 0.000 & 0.000 & 0.000 & 0.000 & 0.000 \\
\hline Mg & 0.000 & 0.000 & 0.000 & 0.000 & 0.000 & 0.000 & 0.000 & 0.000 \\
\hline $\mathrm{Fe}^{2+}$ & 0.000 & 0.000 & 0.000 & 0.000 & 0.000 & 0.000 & 0.000 & 0.000 \\
\hline $\mathrm{Mn}$ & 0.000 & 0.000 & 0.000 & 0.000 & 0.000 & 0.000 & 0.000 & 0.000 \\
\hline $\mathrm{Ca}$ & 1.795 & 1.563 & 1.544 & 1.518 & 1.517 & 1.663 & 1.568 & 1.637 \\
\hline $\mathrm{Na}$ & 0.205 & 0.399 & 0.394 & 0.414 & 0.405 & 0.337 & 0.415 & 0.357 \\
\hline $\mathrm{Ca}$ & 0.000 & 0.000 & 0.000 & 0.000 & 0.000 & 0.000 & 0.000 & 0.000 \\
\hline $\mathrm{Na}$ & 0.181 & 0.000 & 0.000 & 0.000 & 0.000 & 0.045 & 0.000 & 0.000 \\
\hline K & 0.175 & 0.213 & 0.197 & 0.199 & 0.206 & 0.244 & 0.209 & 0.207 \\
\hline CCL & 0.000 & 0.051 & 0.054 & 0.036 & 0.054 & 0.069 & 0.050 & 0.050 \\
\hline CF & 0.000 & 0.207 & 0.052 & 0.120 & 0.221 & 0.058 & 0.135 & 0.051 \\
\hline $\mathrm{mg} \#$ & 0.501 & 0.482 & 0.477 & 0.474 & 0.466 & 0.488 & 0.467 & 0.499 \\
\hline
\end{tabular}

$\mathrm{mg} \#=100 *\left[\mathrm{Mg} /\left(\mathrm{Mg}+\mathrm{Fe}^{2+}+\mathrm{Fe}^{3+}\right)\right]$

mfeno: microfenocristal; feno: fenocristal; idio: idiomórfico: sub-idio: sub-idiomórfico; xeno: xenomórfico;

frat: fraturado; corr: corroído; ox: oxidado; incl: inclusão; frag: fragmento 
ANEXO V - Tabelas 4.

\section{Análise química dos anfibólios}

UFRS

Amostra: PUL-44B

\begin{tabular}{|c|c|c|c|c|c|c|c|c|}
\hline análise & $\begin{array}{l}\text { 19c } \\
\text { feno idio com } \\
\text { bordas ox }\end{array}$ & $19 \mathrm{~B}$ & $\begin{array}{c}\text { anf.24 } \\
\text { feno idio com } \\
\text { fina borda ox }\end{array}$ & $\begin{array}{l}\quad 29.1 \mathrm{c} \\
\text { feno sub-idio com } \\
\text { bordas ox e } \\
\text { pouco frat }\end{array}$ & $\begin{array}{l}\text { anf.29.2i } \\
\text { idem; } i\end{array}$ & $\begin{array}{l}\text { anf.29.3i } \\
\text { idem; } i\end{array}$ & $\begin{array}{l}\text { anf.29.4b } \\
\text { idem; } b\end{array}$ & $\begin{array}{l}\text { anf.14c } \\
\text { mfeno idio }\end{array}$ \\
\hline $\mathrm{SiO}_{2}$ & 45.006 & 45.084 & 44.401 & 44.116 & 44.616 & 44.763 & 44.026 & 44.762 \\
\hline $\mathrm{TiO}_{2}$ & 1.785 & 1.704 & 1.562 & 1.718 & 1.654 & 1.696 & 1.890 & 1.714 \\
\hline $\mathrm{Al}_{2} \mathrm{O}_{3}$ & 9.050 & 9.132 & 9.112 & 9.474 & 9.030 & 9.207 & 9.725 & 8.988 \\
\hline $\mathrm{FeO}$ & 18.723 & 18.279 & 19.663 & 19.751 & 19.153 & 19.890 & 19.747 & 19.384 \\
\hline $\mathrm{Cr}_{2} \mathrm{O}_{3}$ & 0.000 & 0.000 & 0.000 & 0.000 & 0.000 & 0.000 & 0.000 & 0.000 \\
\hline $\mathrm{MnO}$ & 0.201 & 0.184 & 0.168 & 0.162 & 0.180 & 0.170 & 0.170 & 0.162 \\
\hline $\mathrm{MgO}$ & 10.714 & 10.590 & 10.160 & 9.804 & 10.003 & 10.069 & 9.979 & 10.177 \\
\hline $\mathrm{CaO}$ & 10.260 & 10.441 & 10.135 & 11.165 & 10.995 & 9.690 & 9.727 & 10.178 \\
\hline $\mathrm{Na}_{2} \mathrm{O}$ & 1.298 & 1.367 & 1.533 & 1.489 & 1.356 & 1.294 & 1.483 & 1.303 \\
\hline $\mathrm{K}_{2} \mathrm{O}$ & 1.165 & 1.177 & 1.051 & 1.075 & 0.978 & 1.075 & 1.105 & 1.069 \\
\hline$F$ & 0.259 & 0.334 & 0.080 & 0.257 & 0.106 & 0.515 & 0.000 & 0.143 \\
\hline $\mathrm{Cl}$ & 0.177 & 0.244 & 0.188 & 0.226 & 0.213 & 0.149 & 0.212 & 0.232 \\
\hline Total & 98.640 & 98.540 & 98.050 & 99.240 & 98.280 & 98.520 & 98.060 & 98.110 \\
\hline \multicolumn{9}{|c|}{ Cátions para 23 oxigênios } \\
\hline $\mathrm{Si}$ & 6.588 & 6.634 & 6.556 & 6.529 & 6.623 & 6.563 & 6.472 & 6.601 \\
\hline Al & 1.412 & 1.366 & 1.444 & 1.471 & 1.377 & 1.437 & 1.528 & 1.399 \\
\hline $\mathrm{Fe}^{3+}$ & 0.000 & 0.000 & 0.000 & 0.000 & 0.000 & 0.000 & 0.000 & 0.000 \\
\hline $\mathrm{Ti}$ & 0.000 & 0.000 & 0.000 & 0.000 & 0.000 & 0.000 & 0.000 & 0.000 \\
\hline Al & 0.148 & 0.216 & 0.141 & 0.181 & 0.201 & 0.152 & 0.155 & 0.162 \\
\hline $\mathrm{Cr}$ & 0.000 & 0.000 & 0.000 & 0.000 & 0.000 & 0.000 & 0.000 & 0.000 \\
\hline $\mathrm{Fe}^{3+}$ & 1.066 & 0.870 & 1.112 & 0.736 & 0.733 & 1.298 & 1.261 & 1.067 \\
\hline $\mathrm{Ti}$ & 0.197 & 0.189 & 0.173 & 0.191 & 0.185 & 0.187 & 0.209 & 0.190 \\
\hline $\mathrm{Mg}$ & 2.338 & 2.323 & 2.237 & 2.163 & 2.214 & 2.201 & 2.187 & 2.237 \\
\hline $\mathrm{Fe}^{2+}$ & 1.226 & 1.379 & 1.316 & 1.708 & 1.644 & 1.141 & 1.167 & 1.323 \\
\hline $\mathrm{Mn}$ & 0.025 & 0.023 & 0.021 & 0.020 & 0.023 & 0.021 & 0.021 & 0.020 \\
\hline $\mathrm{Ca}$ & 0.000 & 0.000 & 0.000 & 0.000 & 0.000 & 0.000 & 0.000 & 0.000 \\
\hline $\mathrm{Mg}$ & 0.000 & 0.000 & 0.000 & 0.000 & 0.000 & 0.000 & 0.000 & 0.000 \\
\hline $\mathrm{Fe}^{\alpha^{2+}}$ & 0.000 & 0.000 & 0.000 & 0.000 & 0.000 & 0.000 & 0.000 & 0.000 \\
\hline $\mathrm{Mn}$ & 0.000 & 0.000 & 0.000 & 0.000 & 0.000 & 0.000 & 0.000 & 0.000 \\
\hline $\mathrm{Ca}$ & 1.609 & 1.646 & 1.603 & 1.770 & 1.749 & 1.522 & 1.532 & 1.608 \\
\hline $\mathrm{Na}$ & 0.368 & 0.354 & 0.397 & 0.230 & 0.251 & 0.368 & 0.423 & 0.373 \\
\hline $\mathrm{Ca}$ & 0.000 & 0.000 & 0.000 & 0.000 & 0.000 & 0.000 & 0.000 & 0.000 \\
\hline $\mathrm{Na}$ & 0.000 & 0.036 & 0.042 & 0.198 & 0.139 & 0.000 & 0.000 & 0.000 \\
\hline $\mathrm{K}$ & 0.218 & 0.221 & 0.198 & 0.203 & 0.185 & 0.201 & 0.207 & 0.201 \\
\hline $\mathrm{CCL}$ & 0.044 & 0.061 & 0.047 & 0.057 & 0.054 & 0.037 & 0.053 & 0.058 \\
\hline CF & 0.120 & 0.155 & 0.037 & 0.120 & 0.050 & 0.239 & 0.000 & 0.067 \\
\hline $\mathrm{mg} \#$ & 0.505 & 0.508 & 0.480 & 0.470 & 0.482 & 0.474 & 0.474 & 0.483 \\
\hline
\end{tabular}

$\mathrm{mg} \#=100 *\left[\mathrm{Mg} /\left(\mathrm{Mg}+\mathrm{Fe}^{2+}+\mathrm{Fe}^{3+}\right)\right]$

mfeno: microfenocristal; feno: fenocristal; idio: idiomórfico: sub-idio: sub-idiomórfico; xeno: xenomórfico;

frat: fraturado; corr: corroído; ox: oxidado; incl: inclusão; frag: fragmento 
ANEXO V - Tabelas 4.

\section{Análise química dos anfibólios}

UFRS

Amostra: PUL-44B

Amostra: PUL-44C

\begin{tabular}{|c|c|c|c|c|c|c|c|}
\hline análise & \begin{tabular}{l}
\multicolumn{1}{c}{ anf.22c } \\
sub-idio com \\
margens ox e \\
incl de opa e \\
plad
\end{tabular} & $\begin{array}{l}\text { anf.28c } \\
\text { mfeno idio }\end{array}$ & $\begin{array}{l}\quad \text { anf.2c } \\
\text { mfeno sub- } \\
\text { idio com incl } \\
\text { plag }\end{array}$ & feno sub-idio & $\begin{array}{l}\text { anf.x12c } \\
\text { feno sub-idio } \\
\text { corr e ox }\end{array}$ & $\begin{array}{c}\text { anf.12c } \\
\text { mfeno idio ox }\end{array}$ & $\begin{array}{l}\quad \text { anf.1c } \\
\text { feno sub-idio } \\
\text { corr e bordas } \\
\text { ox }\end{array}$ \\
\hline $\mathrm{SiO}_{2}$ & 44.333 & 44.457 & 44.983 & 44.469 & 44.926 & 44.882 & 44.823 \\
\hline $\mathrm{TiO}_{2}$ & 1.710 & 1.814 & 1.652 & 1.648 & 1.794 & 1.791 & 1.708 \\
\hline $\mathrm{Al}_{2} \mathrm{O}_{3}$ & 9.080 & 9.302 & 8.931 & 9.249 & 9.106 & 9.083 & 9.318 \\
\hline $\mathrm{FeO}$ & 19.151 & 19.585 & 19.651 & 19.814 & 18.044 & 19.001 & 19.440 \\
\hline $\mathrm{Cr}_{2} \mathrm{O}_{3}$ & 0.000 & 0.000 & 0.000 & 0.000 & 0.000 & 0.000 & 0.000 \\
\hline $\mathrm{MnO}$ & 0.189 & 0.174 & 0.234 & 0.194 & 0.154 & 0.208 & 0.245 \\
\hline $\mathrm{MgO}$ & 10.116 & 9.917 & 10.268 & 9.875 & 10.842 & 10.269 & 9.931 \\
\hline $\mathrm{CaO}$ & 10.992 & 11.286 & 11.066 & 11.293 & 11.071 & 11.075 & 9.860 \\
\hline $\mathrm{Na}_{2} \mathrm{O}$ & 1.376 & 1.267 & 1.356 & 1.417 & 1.290 & 1.330 & 1.373 \\
\hline $\mathrm{K}_{2} \mathrm{O}$ & 0.889 & 1.014 & 0.930 & 1.028 & 1.042 & 0.960 & 1.140 \\
\hline $\mathrm{F}$ & 0.403 & 0.156 & 0.549 & 0.147 & 0.294 & 0.368 & 0.116 \\
\hline $\mathrm{Cl}$ & 0.187 & 0.177 & 0.218 & 0.171 & 0.184 & 0.215 & 0.206 \\
\hline Total & 98.430 & 99.150 & 99.840 & 99.310 & 98.750 & 99.180 & 98.160 \\
\hline \multicolumn{8}{|c|}{ Cátions para 23 oxigênios } \\
\hline Si & 6.581 & 6.561 & 6.594 & 6.565 & 6.608 & 6.608 & 6.595 \\
\hline Al & 1.419 & 1.439 & 1.406 & 1.435 & 1.392 & 1.392 & 1.405 \\
\hline $\mathrm{Fe}^{3+}$ & 0.000 & 0.000 & 0.000 & 0.000 & 0.000 & 0.000 & 0.000 \\
\hline $\mathrm{Ti}$ & 0.000 & 0.000 & 0.000 & 0.000 & 0.000 & 0.000 & 0.000 \\
\hline Al & 0.169 & 0.178 & 0.136 & 0.173 & 0.185 & 0.182 & 0.210 \\
\hline $\mathrm{Cr}$ & 0.000 & 0.000 & 0.000 & 0.000 & 0.000 & 0.000 & 0.000 \\
\hline $\mathrm{Fe}^{3+}$ & 0.807 & 0.736 & 0.870 & 0.724 & 0.757 & 0.759 & 1.102 \\
\hline $\mathrm{Ti}$ & 0.191 & 0.201 & 0.182 & 0.183 & 0.198 & 0.198 & 0.189 \\
\hline $\mathrm{Mg}$ & 2.239 & 2.182 & 2.244 & 2.173 & 2.377 & 2.254 & 2.178 \\
\hline $\mathrm{Fe}^{2+}$ & 1.571 & 1.681 & 1.539 & 1.722 & 1.463 & 1.580 & 1.290 \\
\hline $\mathrm{Mn}$ & 0.024 & 0.022 & 0.029 & 0.024 & 0.019 & 0.026 & 0.031 \\
\hline $\mathrm{Ca}$ & 0.000 & 0.000 & 0.000 & 0.000 & 0.000 & 0.000 & 0.000 \\
\hline Mg & 0.000 & 0.000 & 0.000 & 0.000 & 0.000 & 0.000 & 0.000 \\
\hline $\mathrm{Fe}^{\alpha^{+}}$ & 0.000 & 0.000 & 0.000 & 0.000 & 0.000 & 0.000 & 0.000 \\
\hline $\mathrm{Mn}$ & 0.000 & 0.000 & 0.000 & 0.000 & 0.000 & 0.000 & 0.000 \\
\hline $\mathrm{Ca}$ & 1.748 & 1.785 & 1.738 & 1.786 & 1.745 & 1.747 & 1.554 \\
\hline $\mathrm{Na}$ & 0.252 & 0.215 & 0.262 & 0.214 & 0.255 & 0.253 & 0.392 \\
\hline $\mathrm{Ca}$ & 0.000 & 0.000 & 0.000 & 0.000 & 0.000 & 0.000 & 0.000 \\
\hline $\mathrm{Na}$ & 0.144 & 0.147 & 0.123 & 0.192 & 0.113 & 0.127 & 0.000 \\
\hline K & 0.168 & 0.191 & 0.174 & 0.194 & 0.196 & 0.180 & 0.214 \\
\hline $\mathrm{CCL}$ & 0.047 & 0.044 & 0.054 & 0.043 & 0.046 & 0.054 & 0.051 \\
\hline CF & 0.189 & 0.073 & 0.255 & 0.069 & 0.137 & 0.171 & 0.054 \\
\hline $\mathrm{mg} \#$ & 0.485 & 0.474 & 0.482 & 0.470 & 0.517 & 0.491 & 0.477 \\
\hline
\end{tabular}

$\mathrm{mg} \#=100 *\left[\mathrm{Mg} /\left(\mathrm{Mg}+\mathrm{Fe}^{2+}+\mathrm{Fe}^{3+}\right)\right]$

mfeno: microfenocristal; feno: fenocristal; idio: idiomórfico: sub-idio: sub-idiomórfico; xeno: xenomórfico;

frat: fraturado; corr: corroído; ox: oxidado; incl: inclusão; frag: fragmento 
ANEXO V - Tabelas 4.

Análise química dos anfibólios

UFRS

Amostra: PUL-44C

\begin{tabular}{|c|c|c|c|c|}
\hline $\begin{array}{l}\text { anf.11c } \\
\text { mfeno idio }\end{array}$ & $\begin{array}{l}\quad \text { anf.13c } \\
\text { mfeno idio } \\
\text { levemente } \\
\text { corr }\end{array}$ & $\begin{array}{l}\quad \text { anf.14c } \\
\text { frag feno sub- } \\
\text { idio }\end{array}$ & $\begin{array}{l}\text { anf.15c } \\
\text { frag feno com } \\
\text { bordas corr e } \\
\text { ox }\end{array}$ & $\begin{array}{c}\text { anf.16c } \\
\text { frag feno idio }\end{array}$ \\
\hline $44.565 \mathrm{SiO}_{2}$ & 44.679 & 44.509 & 44.593 & 44.865 \\
\hline $1.897 \mathrm{TiO}_{2}$ & 1.772 & 2.024 & 1.701 & 1.487 \\
\hline $9.208 \mathrm{Al}_{2} \mathrm{O}_{3}$ & 9.271 & 9.165 & 9.120 & 9.230 \\
\hline $19.043 \mathrm{FeO}$ & 18.896 & 19.965 & 18.980 & 19.414 \\
\hline $0.000 \mathrm{Cr}_{2} \mathrm{O}_{3}$ & 0.000 & 0.000 & 0.000 & 0.000 \\
\hline $0.191 \mathrm{MnO}$ & 0.236 & 0.238 & 0.182 & 0.191 \\
\hline $10.286 \mathrm{MgO}$ & 10.318 & 10.212 & 10.576 & 10.100 \\
\hline $11.237 \mathrm{CaO}$ & 11.201 & 10.943 & 11.246 & 11.164 \\
\hline $1.429 \mathrm{Na}_{2} \mathrm{O}$ & 1.388 & 1.463 & 1.419 & 1.391 \\
\hline $1.091 \mathrm{~K}_{2} \mathrm{O}$ & 0.963 & 1.031 & 1.022 & 0.965 \\
\hline $0.156 \mathrm{~F}$ & 0.299 & 0.013 & 0.260 & 0.222 \\
\hline $0.240 \mathrm{Cl}$ & 0.215 & 0.184 & 0.164 & 0.212 \\
\hline 99.340 Total & 99.240 & 99.750 & 99.260 & 99.240 \\
\hline & \multicolumn{4}{|c|}{ Cátions para 23 oxigênios } \\
\hline $6.564 \mathrm{Si}$ & 6.577 & 6.505 & 6.557 & 6.605 \\
\hline $1.436 \mathrm{Al}$ & 1.423 & 1.495 & 1.443 & 1.395 \\
\hline $0.000 \mathrm{Fe}^{3+}$ & 0.000 & 0.000 & 0.000 & 0.000 \\
\hline $0.000 \mathrm{Ti}$ & 0.000 & 0.000 & 0.000 & 0.000 \\
\hline $0.162 \mathrm{Al}$ & 0.184 & 0.083 & 0.137 & 0.205 \\
\hline $0.000 \mathrm{Cr}$ & 0.000 & 0.000 & 0.000 & 0.000 \\
\hline $0.694 \mathrm{Fe}^{3+}$ & 0.737 & 0.933 & 0.790 & 0.761 \\
\hline $0.210 \mathrm{Ti}$ & 0.196 & 0.223 & 0.188 & 0.165 \\
\hline $2.259 \mathrm{Mg}$ & 2.264 & 2.225 & 2.318 & 2.217 \\
\hline $1.652 \mathrm{Fe}^{2+}$ & 1.590 & 1.507 & 1.544 & 1.629 \\
\hline $0.024 \mathrm{Mn}$ & 0.029 & 0.029 & 0.023 & 0.024 \\
\hline $0.000 \mathrm{Ca}$ & 0.000 & 0.000 & 0.000 & 0.000 \\
\hline $0.000 \mathrm{Mg}$ & 0.000 & 0.000 & 0.000 & 0.000 \\
\hline $0.000 \mathrm{Fe}^{\mathrm{L}_{+}}$ & 0.000 & 0.000 & 0.000 & 0.000 \\
\hline $0.000 \mathrm{Mn}$ & 0.000 & 0.000 & 0.000 & 0.000 \\
\hline $1.773 \mathrm{Ca}$ & 1.767 & 1.714 & 1.772 & 1.761 \\
\hline $0.227 \mathrm{Na}$ & 0.233 & 0.286 & 0.228 & 0.239 \\
\hline $0.000 \mathrm{Ca}$ & 0.000 & 0.000 & 0.000 & 0.000 \\
\hline $0.182 \mathrm{Na}$ & 0.163 & 0.128 & 0.176 & 0.158 \\
\hline $0.205 \mathrm{~K}$ & 0.181 & 0.192 & 0.192 & 0.181 \\
\hline $0.060 \mathrm{CCL}$ & 0.054 & 0.046 & 0.041 & 0.053 \\
\hline $0.073 \mathrm{CF}$ & 0.139 & 0.006 & 0.121 & 0.103 \\
\hline $0.491 \mathrm{mg} \#$ & 0.493 & 0.477 & 0.498 & 0.481 \\
\hline
\end{tabular}

$\mathrm{mg} \#=100 *\left[\mathrm{Mg} /\left(\mathrm{Mg}+\mathrm{Fe}^{2+}+\mathrm{Fe}^{3+}\right)\right]$

mfeno: microfenocristal; feno: fenocristal; idio: idiomórfico: sub-idio: sub-idiomórfico; xeno: xenomórfico; frat: fraturado; corr: corroído; ox: oxidado; incl: inclusão; frag: fragmento 
ANEXO VI. Análises de Geoquimica

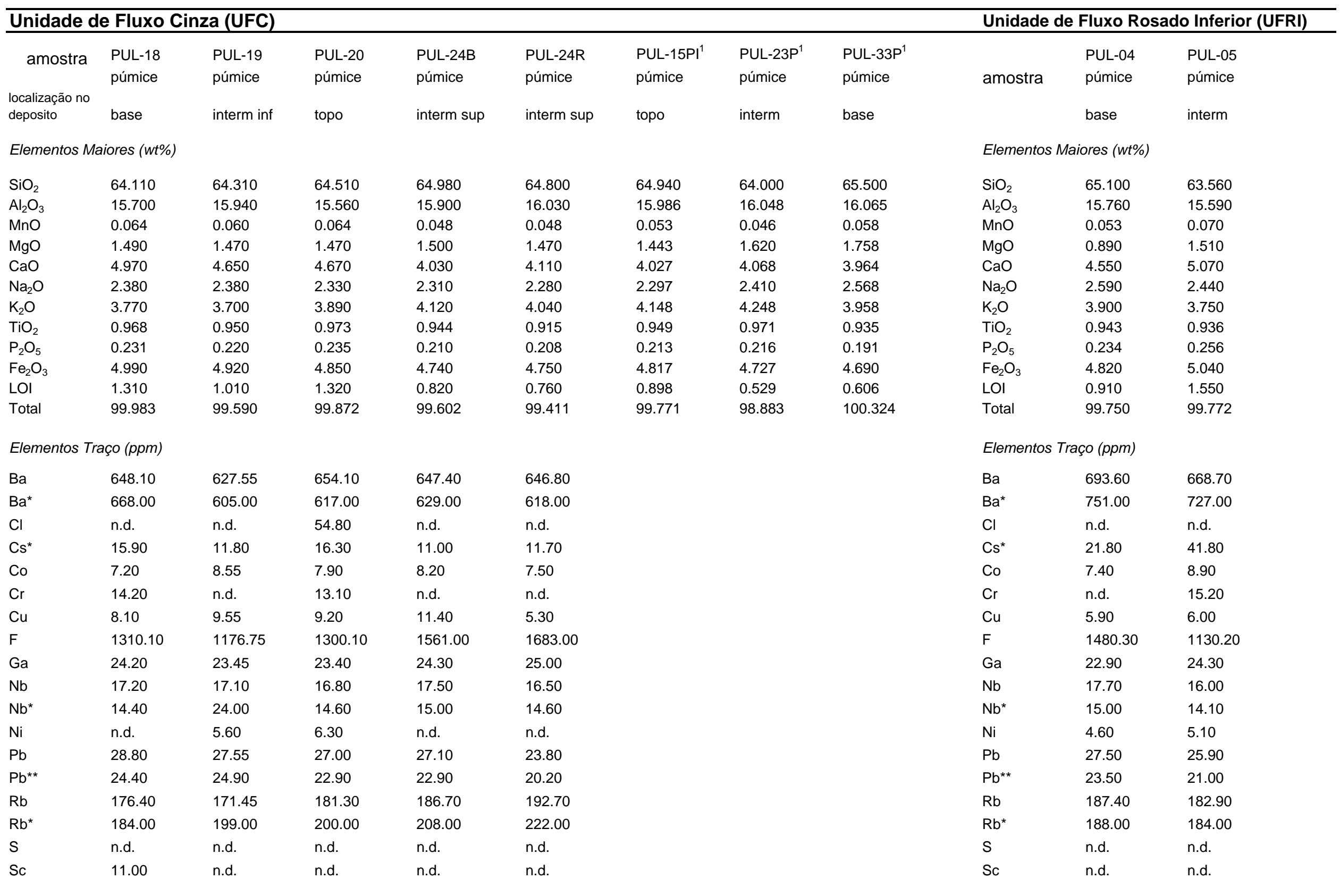




\begin{tabular}{|c|c|c|c|c|c|c|c|c|}
\hline $\mathrm{Sr}$ & 287.10 & 282.50 & 288.40 & 259.00 & 263.70 & $\mathrm{Sr}$ & 285.00 & 282.80 \\
\hline $\mathrm{Sr}^{*}$ & 291.00 & 308.00 & 299.00 & 266.00 & 278.00 & $\mathrm{Sr}^{*}$ & 284.00 & 279.00 \\
\hline $\mathrm{Ta}^{*}$ & 1.30 & 3.25 & 1.36 & 1.33 & 1.34 & $\mathrm{Ta}^{*}$ & 1.33 & 1.22 \\
\hline Th & 19.30 & 18.30 & 19.70 & 18.30 & 16.90 & Th & 20.40 & 17.90 \\
\hline $\mathrm{Th}^{*}$ & 14.40 & 15.90 & 15.50 & 16.10 & 14.70 & $\mathrm{Th}^{\star}$ & 11.50 & 11.80 \\
\hline$U$ & 8.50 & 6.50 & 7.40 & 6.60 & 7.60 & $\mathrm{U}$ & 8.40 & 8.60 \\
\hline$U^{*}$ & 4.36 & 4.39 & 4.31 & 4.39 & 4.59 & $U^{*}$ & 3.97 & 4.05 \\
\hline V & 80.40 & 74.95 & 88.30 & 85.40 & 66.00 & v & 104.60 & 71.60 \\
\hline Y & 25.20 & 26.25 & 24.10 & 25.40 & 26.60 & $Y$ & 24.10 & 23.20 \\
\hline$Y^{*}$ & 21.50 & 24.40 & 20.80 & 21.00 & 22.70 & $Y^{*}$ & 19.70 & 19.00 \\
\hline $\mathrm{Zn}$ & 119.50 & 131.45 & 118.80 & 145.20 & 125.90 & $\mathrm{Zn}$ & 125.60 & 103.00 \\
\hline $\mathrm{Zr}$ & 192.10 & 191.90 & 195.80 & 197.40 & 192.90 & $\mathrm{Zr}$ & 196.00 & 185.30 \\
\hline La & 41.10 & 40.40 & 40.20 & 40.70 & 35.80 & La & 33.50 & 41.20 \\
\hline $\mathrm{La}^{\star *}$ & 36.30 & 34.30 & 33.80 & 52.00 & n.d. & $\mathrm{La}^{\star \star}$ & n.d. & 37.80 \\
\hline $\mathrm{Ce}$ & 89.40 & 88.00 & 87.70 & 90.30 & 80.50 & $\mathrm{Ce}$ & 76.30 & 88.00 \\
\hline $\mathrm{Ce}^{\star *}$ & 38.80 & 40.90 & 46.30 & 37.80 & 36.90 & $\mathrm{Ce}^{\star \star}$ & 37.00 & n.d. \\
\hline $\mathrm{Pr}$ & 10.20 & 10.20 & 10.00 & 10.30 & 9.68 & $\mathrm{Pr}$ & 8.63 & 10.20 \\
\hline $\mathrm{Nd}$ & 38.80 & 39.10 & 38.00 & 39.40 & 37.80 & $\mathrm{Nd}$ & 33.60 & 38.50 \\
\hline $\mathrm{Nd}^{\star \star}$ & 23.10 & 27.80 & 23.90 & 31.00 & 23.00 & $\mathrm{Nd}^{\star \star}$ & 26.90 & 35.60 \\
\hline $\mathrm{Sm}$ & 7.53 & 7.75 & 7.43 & 7.71 & 7.74 & $\mathrm{Sm}$ & 7.02 & 7.37 \\
\hline $\mathrm{Eu}$ & 1.47 & 1.49 & 1.45 & 1.52 & 1.61 & $\mathrm{Eu}$ & 1.42 & 1.52 \\
\hline $\mathrm{Gd}$ & 5.90 & 6.19 & 5.85 & 6.11 & 6.29 & $\mathrm{Gd}$ & 5.49 & 5.61 \\
\hline $\mathrm{Tb}$ & 0.84 & 0.90 & 0.83 & 0.85 & 0.90 & $\mathrm{~Tb}$ & 0.79 & 0.78 \\
\hline Dy & 4.21 & 4.55 & 4.09 & 4.18 & 4.41 & Dy & 3.95 & 3.90 \\
\hline Ho & 0.77 & 0.82 & 0.73 & 0.73 & 0.77 & $\mathrm{Ho}$ & 0.70 & 0.69 \\
\hline $\mathrm{Er}$ & 1.93 & 2.08 & 1.81 & 1.83 & 1.93 & $\mathrm{Er}$ & 1.70 & 1.73 \\
\hline Tm & 0.25 & 0.27 & 0.24 & 0.23 & 0.25 & $\mathrm{Tm}$ & 0.22 & 0.22 \\
\hline $\mathrm{Yb}$ & 1.49 & 1.59 & 1.37 & 1.35 & 1.45 & $\mathrm{Yb}$ & 1.29 & 1.30 \\
\hline Lu & 0.21 & 0.23 & 0.20 & 0.19 & 0.21 & Lu & 0.18 & 0.18 \\
\hline
\end{tabular}

Tabela V. Análises de elementos maiores, traços e terras raras de amostras representativas de lapilli-púmices das diferentes unidades reconhecidas no cerro Pululus. Elementos maiores e traços obtidas por FRX e elementos terras raras por ICP-MS.

${ }^{1}$ Análises realizadas no laboratório de Fluorescência de raio-X do Instituto de Geologia y Mineria da Universidad Nacional de Jujuy - Argentina.

${ }^{2}$ Amostra do domo de lava intrusivo do Cerro Pululu

${ }^{3}$ Amostra do Ignimbrito Vilama

* análises de elementos traços pelo método ICP-MS

** análises de elementos terras raras pelo método FRX

n.d.= não detectado

n.a.= não analisado 
ANEXO VI. Análises de Geoquimica

\begin{tabular}{|c|c|c|c|c|c|c|c|c|c|c|c|}
\hline \multicolumn{8}{|c|}{ Unidade de Fluxo Rosado Inferior (UFRI) } & \multicolumn{4}{|c|}{ Unidade de Fluxo Rosada Superior (UFRS) } \\
\hline \multirow[t]{2}{*}{ amostra } & $\begin{array}{l}\text { PUL-10 M } \\
\text { matriz/R.T. }\end{array}$ & $\begin{array}{l}\text { PUL-30 } \\
\text { púmice }\end{array}$ & $\begin{array}{l}\text { PUL-32 } \\
\text { púmice }\end{array}$ & $\begin{array}{l}\text { PUL-31 } \\
\text { púmice }\end{array}$ & $\begin{array}{l}\text { PUL-38E } \\
\text { lítico/R.T. }\end{array}$ & $\begin{array}{l}\text { PUL-29 } \\
\text { púmice }\end{array}$ & $\begin{array}{l}\text { PUL-36 }{ }^{1} \\
\text { púmice }\end{array}$ & amostra & PUL-06 & PUL-21 & PUL-44 PC \\
\hline & interm & interm & base & topo & interm & topo & topo & & púmice & púmice & púmice \\
\hline \multicolumn{8}{|c|}{ Elementos Maiores (wt\%) } & \multicolumn{4}{|c|}{ Elementos Maiores (wt\%) } \\
\hline $\mathrm{SiO}_{2}$ & 63.980 & 63.770 & 65.740 & 65.290 & 65.370 & 66.100 & 65.360 & $\mathrm{SiO}_{2}$ & 65.080 & 64.230 & 64.430 \\
\hline $\mathrm{Al}_{2} \mathrm{O}_{3}$ & 15.870 & 15.200 & 15.745 & 15.840 & 15.650 & 16.042 & 16.780 & $\mathrm{Al}_{2} \mathrm{O}_{3}$ & 15.690 & 16.260 & 16.340 \\
\hline $\mathrm{MnO}$ & 0.520 & 0.091 & 0.014 & 0.052 & 0.057 & 0.060 & 0.061 & $\mathrm{MnO}$ & 0.055 & 0.057 & 0.072 \\
\hline $\mathrm{MgO}$ & 1.420 & 1.070 & 0.805 & 1.270 & 1.480 & 1.284 & 0.467 & $\mathrm{MgO}$ & 0.950 & 1.400 & 1.810 \\
\hline $\mathrm{CaO}$ & 4.310 & 4.970 & 3.990 & 3.880 & 4.170 & 4.040 & 3.723 & $\mathrm{CaO}$ & 4.510 & 4.540 & 4.720 \\
\hline $\mathrm{Na}_{2} \mathrm{O}$ & 2.390 & 2.360 & 2.545 & 2.360 & 2.515 & 2.628 & 2.721 & $\mathrm{Na}_{2} \mathrm{O}$ & 2.480 & 2.510 & 2.370 \\
\hline $\mathrm{K}_{2} \mathrm{O}$ & 3.790 & 3.750 & 4.135 & 4.030 & 3.885 & 3.937 & 3.987 & $\mathrm{~K}_{2} \mathrm{O}$ & 3.750 & 3.770 & 3.440 \\
\hline $\mathrm{TiO}_{2}$ & 0.961 & 0.847 & 0.891 & 0.883 & 0.887 & 0.854 & 0.945 & $\mathrm{TiO}_{2}$ & 0.873 & 0.943 & 0.946 \\
\hline $\mathrm{P}_{2} \mathrm{O}_{5}$ & 0.211 & 0.200 & 0.209 & 0.195 & 0.213 & 0.196 & 0.201 & $\mathrm{P}_{2} \mathrm{O}_{5}$ & 0.210 & 0.243 & 0.192 \\
\hline $\mathrm{Fe}_{2} \mathrm{O}_{3}$ & 5.170 & 5.020 & 4.385 & 4.720 & 4.510 & 4.381 & 4.720 & $\mathrm{Fe}_{2} \mathrm{O}_{3}$ & 4.460 & 5.040 & 5.220 \\
\hline LOI & 1.820 & 2.670 & 1.490 & 1.190 & 0.945 & 0.458 & 0.736 & LOI & 1.490 & 0.670 & 0.570 \\
\hline Total & 100.442 & 99.948 & 99.949 & 99.710 & 99.682 & 99.980 & 99.701 & Total & 99.548 & 99.663 & 100.110 \\
\hline \multicolumn{8}{|c|}{ Elementos Traço (ppm) } & \multicolumn{4}{|c|}{ Elementos Traço (ppm) } \\
\hline $\mathrm{Ba}$ & 691.80 & 630.40 & 621.60 & 655.20 & 617.05 & & & $\mathrm{Ba}$ & 1093.10 & 643.20 & 609.70 \\
\hline $\mathrm{Ba}^{*}$ & 614.00 & 558.00 & 551.00 & 578.00 & 608.00 & & & $\mathrm{Ba}^{*}$ & 1153.00 & 628.00 & 537.00 \\
\hline $\mathrm{Cl}$ & n.d. & 1583.70 & 464.45 & 167.50 & 333.80 & & & $\mathrm{Cl}$ & n.d. & n.d. & 236.30 \\
\hline $\mathrm{Cs}^{*}$ & 14.30 & 17.10 & 28.40 & 11.90 & 11.60 & & & $\mathrm{Cs}^{*}$ & 19.50 & 10.00 & 7.66 \\
\hline Co & 7.90 & 7.70 & 5.70 & 6.90 & n.d. & & & Co & 7.60 & 7.60 & 6.60 \\
\hline $\mathrm{Cr}$ & n.d. & 16.40 & 12.10 & n.d. & n.d. & & & $\mathrm{Cr}$ & n.d. & n.d. & 13.10 \\
\hline $\mathrm{Cu}$ & 5.30 & 6.20 & 7.00 & 8.20 & 5.70 & & & $\mathrm{Cu}$ & 4.90 & 6.40 & 6.20 \\
\hline $\mathrm{F}$ & 1214.10 & 1891.40 & 1586.25 & 999.30 & 1571.85 & & & $\mathrm{~F}$ & n.d. & 1140.40 & 637.90 \\
\hline $\mathrm{Ga}$ & 24.80 & 23.00 & 24.10 & 22.90 & 23.05 & & & $\mathrm{Ga}$ & 22.40 & 23.70 & 22.80 \\
\hline $\mathrm{Nb}$ & 17.30 & 15.80 & 16.30 & 16.90 & 16.50 & & & $\mathrm{Nb}$ & 17.00 & 17.20 & 16.70 \\
\hline $\mathrm{Nb}^{*}$ & 11.40 & 10.50 & 8.80 & 11.00 & 15.10 & & & $\mathrm{Nb}^{*}$ & 13.90 & 14.60 & 11.20 \\
\hline $\mathrm{Ni}$ & 4.70 & 4.70 & n.d. & 5.30 & n.d. & & & $\mathrm{Ni}$ & 5.30 & n.d. & 4.90 \\
\hline $\mathrm{Pb}$ & 26.90 & 28.30 & 32.00 & 26.50 & 24.30 & & & $\mathrm{~Pb}$ & 39.70 & 25.80 & 26.00 \\
\hline $\mathrm{Pb}^{\star \star}$ & 19.20 & 20.70 & 20.20 & 23.70 & 21.60 & & & $\mathrm{~Pb}^{\star *}$ & 40.30 & 20.70 & 20.40 \\
\hline $\mathrm{Rb}$ & 180.10 & 176.30 & 195.25 & 193.30 & 182.20 & & & $\mathrm{Rb}$ & 176.50 & 175.80 & 155.80 \\
\hline $\mathrm{Rb}^{*}$ & 172.00 & 178.00 & 181.00 & 188.00 & 219.00 & & & $\mathrm{Rb}^{*}$ & 181.00 & 194.00 & 153.00 \\
\hline $\mathrm{s}$ & 2628.90 & n.d. & 961.95 & n.d. & n.d. & & & $\mathrm{s}$ & n.d. & n.d. & n.d. \\
\hline Sc & n.d. & n.d. & n.d. & n.d. & n.d. & & & Sc & n.d. & n.d. & n.d. \\
\hline
\end{tabular}




\begin{tabular}{|c|c|c|c|c|c|c|c|c|c|}
\hline $\mathrm{Sr}$ & 283.60 & 274.50 & 262.10 & 248.50 & 269.70 & $\mathrm{Sr}$ & 404.60 & 278.70 & 255.70 \\
\hline $\mathrm{Sr}^{*}$ & 247.00 & 252.00 & 219.00 & 220.00 & 299.00 & $\mathrm{Sr}^{\star}$ & 405.00 & 285.00 & 228.00 \\
\hline $\mathrm{Ta}^{*}$ & 0.83 & 0.75 & 0.59 & 0.81 & 1.40 & $\mathrm{Ta}^{*}$ & 1.31 & 1.27 & 0.84 \\
\hline Th & 20.40 & 19.00 & 19.45 & 20.40 & 18.60 & Th & 17.80 & 18.80 & 18.30 \\
\hline$T h^{*}$ & 12.80 & 13.70 & 13.00 & 14.60 & 16.10 & $T h^{*}$ & 13.90 & 14.60 & 12.20 \\
\hline U & 6.80 & 7.70 & 7.55 & 6.60 & 6.65 & $U$ & 6.80 & 7.90 & 7.30 \\
\hline$U^{*}$ & 3.68 & 3.75 & 3.14 & 4.56 & 3.31 & $U^{*}$ & 4.22 & 4.21 & 3.91 \\
\hline V & 98.30 & 100.70 & 99.05 & 71.90 & 93.25 & $\mathrm{~V}$ & 86.80 & 82.50 & 95.50 \\
\hline Y & 24.10 & 22.80 & 22.35 & 25.30 & 23.30 & $Y$ & 23.90 & 25.00 & 29.60 \\
\hline$Y^{*}$ & 16.30 & 16.10 & 14.10 & 18.80 & 19.00 & $Y^{*}$ & 19.50 & 21.30 & 21.70 \\
\hline $\mathrm{Zn}$ & 107.30 & 118.20 & 130.50 & 102.50 & 87.85 & $\mathrm{Zn}$ & 94.90 & 105.80 & 96.00 \\
\hline $\mathrm{Zr}$ & 184.10 & 178.20 & 181.45 & 187.20 & 182.90 & $\mathrm{Zr}$ & 185.00 & 195.30 & 190.10 \\
\hline La & 39.50 & 38.00 & 37.70 & 41.10 & 37.60 & La & 40.70 & 39.60 & 37.00 \\
\hline $\mathrm{La}^{\star \star}$ & 39.20 & 38.10 & 32.70 & 33.70 & 32.60 & $\mathrm{La}^{\star \star}$ & 29.10 & 36.20 & 42.50 \\
\hline $\mathrm{Ce}$ & 86.90 & 83.80 & 84.80 & 89.90 & 81.70 & $\mathrm{Ce}$ & 88.10 & 86.50 & 82.30 \\
\hline $\mathrm{Ce}^{\star \star}$ & 42.90 & 39.30 & 34.60 & 38.10 & n.d & $\mathrm{Ce}^{\star *}$ & 34.70 & 38.50 & 41.90 \\
\hline $\mathrm{Pr}$ & 9.83 & 9.41 & 9.47 & 10.30 & 9.26 & $\mathrm{Pr}$ & 10.00 & 9.91 & 9.39 \\
\hline $\mathrm{Nd}$ & 36.70 & 35.00 & 35.20 & 38.60 & 35.00 & $\mathrm{Nd}$ & 37.90 & 37.80 & 35.60 \\
\hline $\mathrm{Nd}^{\star \star}$ & 30.10 & 25.00 & 23.40 & 26.40 & 25.40 & $\mathrm{Nd}^{\star \star *}$ & 25.50 & 22.20 & 33.70 \\
\hline Sm & 6.87 & 6.69 & 6.71 & 7.37 & 6.95 & $\mathrm{Sm}$ & 7.24 & 7.44 & 6.99 \\
\hline $\mathrm{Eu}$ & 1.42 & 1.34 & 1.37 & 1.40 & 1.47 & $\mathrm{Eu}$ & 1.45 & 1.55 & 1.42 \\
\hline $\mathrm{Gd}$ & 5.37 & 5.33 & 5.36 & 5.95 & 5.54 & $\mathrm{Gd}$ & 5.59 & 5.95 & 5.79 \\
\hline $\mathrm{Tb}$ & 0.73 & 0.73 & 0.72 & 0.83 & 0.79 & $\mathrm{~Tb}$ & 0.79 & 0.84 & 0.85 \\
\hline Dy & 3.59 & 3.53 & 3.43 & 4.05 & 3.82 & Dy & 3.94 & 4.13 & 4.41 \\
\hline Ho & 0.63 & 0.61 & 0.57 & 0.71 & 0.66 & Ho & 0.70 & 0.73 & 0.82 \\
\hline $\mathrm{Er}$ & 1.57 & 1.52 & 1.39 & 1.75 & 1.61 & $\mathrm{Er}$ & 1.72 & 1.81 & 2.12 \\
\hline Tm & 0.20 & 0.19 & 0.16 & 0.23 & 0.20 & $\mathrm{Tm}$ & 0.22 & 0.24 & 0.28 \\
\hline $\mathrm{Yb}$ & 1.16 & 1.12 & 0.96 & 1.35 & 1.15 & $\mathrm{Yb}$ & 1.31 & 1.39 & 1.73 \\
\hline Lu & 0.16 & 0.15 & 0.13 & 0.19 & 0.16 & Lu & 0.19 & 0.20 & 0.25 \\
\hline
\end{tabular}

Tabela V. Análises de elementos maiores, traços e terras raras de amostras representativas de lapilli-púmices das diferentes unidades reconhecidas no cerro Pululus. Elementos maiores e traços obtidas por FRX e elementos terras raras por ICP-MS.

${ }^{1}$ Análises realizadas no laboratório de Fluorescência de raio-X do Instituto de Geologia y Mineria da Universidad Nacional de Jujuy - Argentina.

${ }^{2}$ Amostra do domo de lava intrusivo do Cerro Pululu

${ }^{3}$ Amostra do Ignimbrito Vilama

* análises de elementos traços pelo método ICP-MS

** análises de elementos terras raras pelo método FRX

n.d.= não detectado 
ANEXO VI. Análises de Geoquimica

\begin{tabular}{|c|c|c|c|c|c|}
\hline \multicolumn{6}{|c|}{ Unidade de Fluxo Rosada Superior (UFRS) } \\
\hline \multirow{2}{*}{ amost } & PUL-44 M & PUL-44 PR & PUL- $45^{1}$ & $\mathrm{H}-03^{2}$ & $M-194^{3}$ \\
\hline & matriz/R.T. & púmice & púmice cinza & lava/R.T. & matriz/R \\
\hline \multicolumn{6}{|c|}{ Elementos Maiores (wt\%) } \\
\hline $\mathrm{SiO}_{2}$ & 64.010 & 65.400 & 64.520 & 64.100 & 62.950 \\
\hline $\mathrm{Al}_{2} \mathrm{O}_{3}$ & 16.320 & 15.840 & 16.402 & 16.270 & 16.760 \\
\hline $\mathrm{MnO}$ & 0.075 & 0.063 & 0.081 & 0.052 & 0.058 \\
\hline $\mathrm{MgO}$ & 1.890 & 1.680 & 1.856 & 1.630 & 1.570 \\
\hline $\mathrm{CaO}$ & 4.640 & 4.270 & 4.778 & 4.200 & 4.690 \\
\hline $\mathrm{Na}_{2} \mathrm{O}$ & 2.540 & 2.540 & 2.438 & 2.510 & 2.510 \\
\hline $\mathrm{K}_{2} \mathrm{O}$ & 3.500 & 3.770 & 3.476 & 3.620 & 3.400 \\
\hline $\mathrm{TiO}_{2}$ & 0.968 & 0.892 & 0.957 & 0.860 & 0.953 \\
\hline $\mathrm{P}_{2} \mathrm{O}_{5}$ & 0.211 & 0.195 & 0.195 & 0.208 & 0.213 \\
\hline $\mathrm{Fe}_{2} \mathrm{O}_{3}$ & 5.240 & 4.770 & 5.071 & 4.790 & 5.230 \\
\hline LOI & 0.760 & 0.450 & 0.250 & 1.250 & 1.110 \\
\hline Total & 100.154 & 99.870 & 100.025 & 99.490 & 99.444 \\
\hline \multicolumn{6}{|c|}{ Elementos Traço (ppm) } \\
\hline $\mathrm{Ba}$ & 651.80 & 629.80 & & 676.00 & 661.00 \\
\hline $\mathrm{Ba}^{*}$ & 572.00 & 558.00 & & 608.00 & 601.00 \\
\hline $\mathrm{Cl}$ & 271.00 & 393.20 & & 190.00 & 177.00 \\
\hline $\mathrm{Cs}^{*}$ & 7.47 & 8.78 & & 10.00 & 6.63 \\
\hline Co & 9.40 & 8.40 & & 11.00 & 9.00 \\
\hline $\mathrm{Cr}$ & 14.20 & n.d. & & 16.00 & 13.00 \\
\hline $\mathrm{Cu}$ & 5.80 & 5.70 & & 8.00 & 5.00 \\
\hline $\mathrm{F}$ & 1550.20 & 950.90 & & 1504.00 & 109.00 \\
\hline $\mathrm{Ga}$ & 24.60 & 23.60 & & 25.00 & 25.00 \\
\hline $\mathrm{Nb}$ & 17.50 & 17.90 & & 16.00 & 16.00 \\
\hline $\mathrm{Nb}^{*}$ & 10.70 & 11.20 & & 15.70 & 16.50 \\
\hline $\mathrm{Ni}$ & 5.20 & n.d. & & 5.00 & 5.00 \\
\hline $\mathrm{Pb}$ & 27.10 & 29.60 & & 27.00 & 21.00 \\
\hline $\mathrm{Pb}^{\star \star}$ & 21.50 & 22.20 & & 25.40 & 21.50 \\
\hline $\mathrm{Rb}$ & 146.60 & 165.30 & & 170.00 & 150.00 \\
\hline $\mathrm{Rb}^{*}$ & 137.00 & 155.00 & & 160.00 & 143.00 \\
\hline S & n.d. & n.d. & & 1430.00 & 585.00 \\
\hline Sc & n.d. & n.d. & & n.d. & n.d. \\
\hline
\end{tabular}




\begin{tabular}{|c|c|c|c|c|}
\hline $\mathrm{Sr}$ & 278.50 & 261.50 & 299.00 & 296.00 \\
\hline $\mathrm{Sr}^{*}$ & 241.00 & 225.00 & 304.00 & 305.00 \\
\hline $\mathrm{Ta}^{\star}$ & 0.72 & 0.84 & 1.77 & 1.92 \\
\hline Th & 18.80 & 19.30 & 14.00 & 13.00 \\
\hline $\mathrm{Th}^{\star}$ & 12.80 & 14.10 & 13.20 & 12.40 \\
\hline U & 8.00 & 6.50 & 7.00 & 6.00 \\
\hline$U^{*}$ & 3.83 & 4.37 & 4.32 & 3.62 \\
\hline V & 94.30 & 87.30 & 96.00 & 95.00 \\
\hline Y & 25.20 & 25.00 & 23.00 & 22.00 \\
\hline$Y^{*}$ & 17.80 & 17.40 & 19.40 & 17.70 \\
\hline $\mathrm{Zn}$ & 105.90 & 97.40 & 105.00 & 106.00 \\
\hline $\mathrm{Zr}$ & 190.50 & 186.60 & 180.00 & 182.00 \\
\hline La & 37.90 & 38.80 & 37.90 & 35.40 \\
\hline $\mathrm{La}^{\star *}$ & 32.40 & 46.00 & 39.00 & 38.00 \\
\hline $\mathrm{Ce}$ & 85.00 & 84.70 & 76.20 & 73.30 \\
\hline $\mathrm{Ce}^{\star *}$ & 42.70 & 44.40 & 76.20 & 73.30 \\
\hline $\operatorname{Pr}$ & 9.47 & 9.59 & 9.35 & 9.01 \\
\hline $\mathrm{Nd}$ & 35.70 & 36.10 & 37.60 & 36.60 \\
\hline $\mathrm{Nd}^{\star \star}$ & 29.30 & 28.20 & 33.00 & 34.00 \\
\hline Sm & 6.85 & 6.91 & 7.20 & 7.16 \\
\hline $\mathrm{Eu}$ & 1.41 & 1.35 & 1.64 & 1.76 \\
\hline $\mathrm{Gd}$ & 5.54 & 5.53 & 5.33 & 5.28 \\
\hline $\mathrm{Tb}$ & 0.77 & 0.77 & 0.74 & 0.74 \\
\hline Dy & 3.86 & 3.83 & 3.83 & 3.72 \\
\hline $\mathrm{Ho}$ & 0.68 & 0.67 & 0.74 & 0.70 \\
\hline $\mathrm{Er}$ & 1.70 & 1.67 & 1.75 & 1.62 \\
\hline $\mathrm{Tm}$ & 0.22 & 0.21 & 0.23 & 0.21 \\
\hline Yb & 1.32 & 1.29 & 1.46 & 1.31 \\
\hline Lu & 0.19 & 0.18 & 0.21 & 0.19 \\
\hline
\end{tabular}

Tabela V. Análises de elementos maiores, traços e terras raras de amostras representativas de lapilli-púmices das diferentes unidades reconhecidas no cerro Pululus. Elementos maiores e traços obtidas por FRX e elementos terras raras por ICP-MS.

${ }^{1}$ Análises realizadas no laboratório de Fluorescência de raio-X do Instituto de Geologia y Mineria da Universidad Nacional de Jujuy - Argentina.

${ }^{2}$ Amostra do domo de lava intrusivo do Cerro Pululu

${ }^{3}$ Amostra do Ignimbrito Vilama

* análises de elementos traços pelo método ICP-MS

** análises de elementos terras raras pelo método FRX

n.d.= não detectado

n.a.= não analisado 